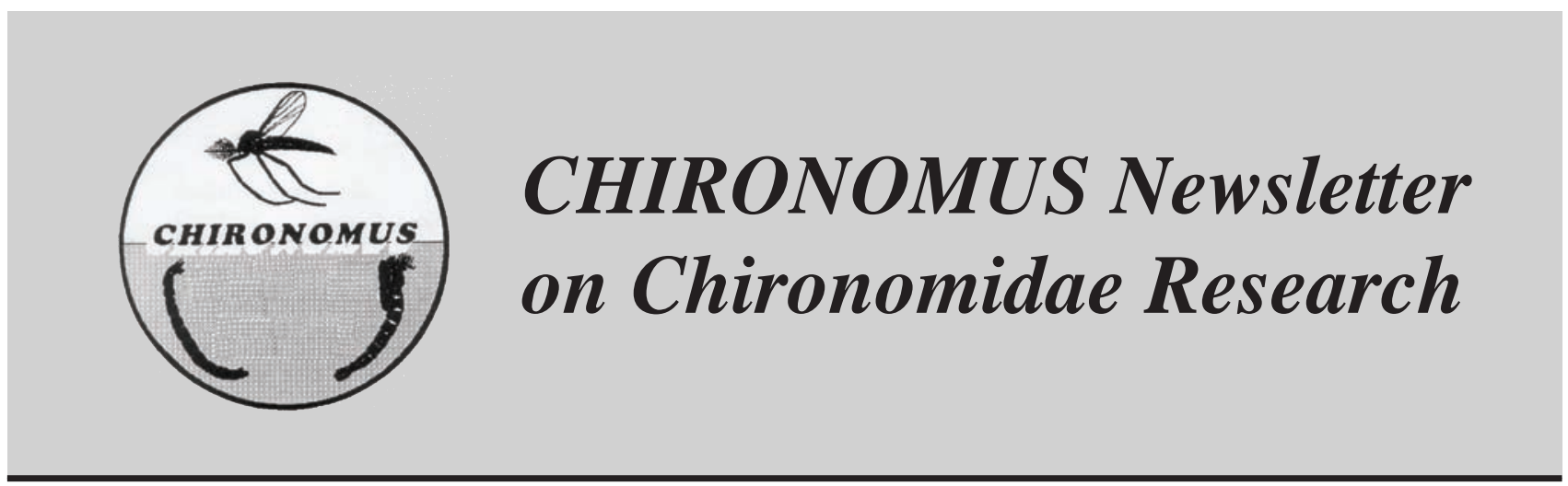

No. 20

ISSN 0172-1941

November 2007

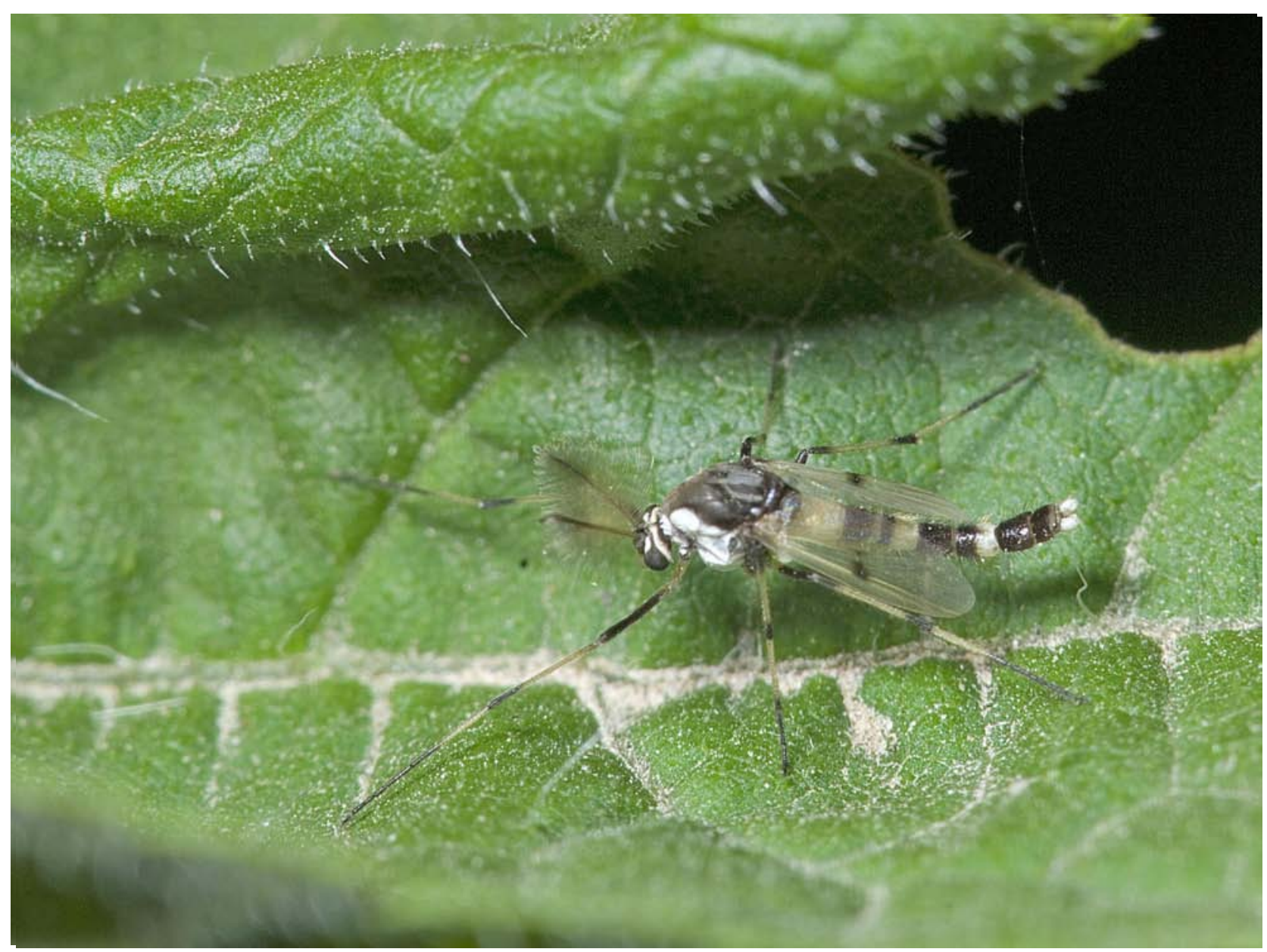

Coelotanypus scapularis, photo ㄷ Steve Marshall, University of Guelph

\title{
CONTENTS
}

Editorial.

A brief biography of Mary Frances Smith Sublette, June 22, 1927 - June 9, 2007.....................................4

Kaare Aagaard 60 years.

Sepp has turned 80 !

Reports from the 16th international chironomid symposium in Funchal, Madeira, July 25-28, 2006.............8

The 8th European subfossil chironomid workshop, Reykjavík 7-8th May, 2007........................................10

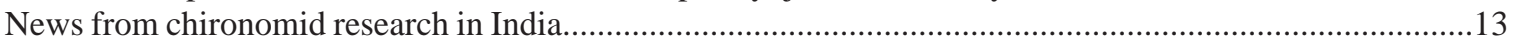

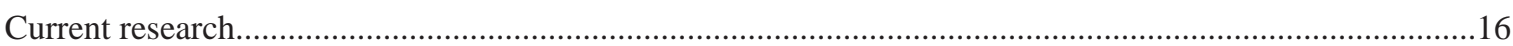

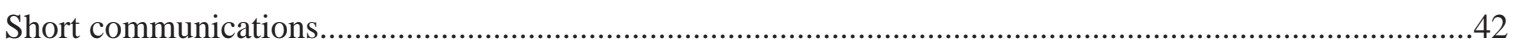

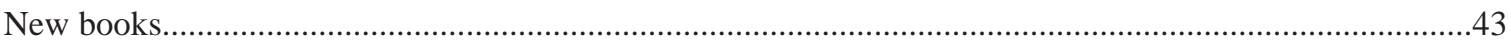

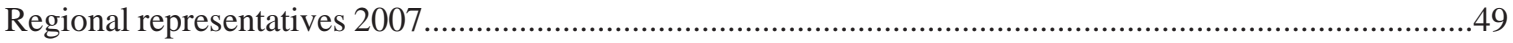

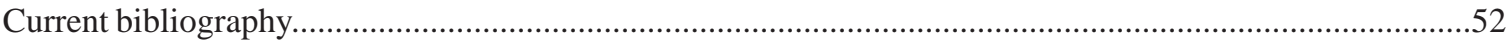




\section{CHIRONOMUS Newsletter on Chironomidae Research}

\section{Editors}

Torbjørn EKREM, Museum of Natural History and Archaeology, Norwegian University of Science and Technology, NO-7491 Trondheim, Norway

Peter H. Langton, 5 Kylebeg Avenue, Mountsandel, Coleraine, Co. Londonderry, Northern Ireland, BT52 1 JN, Northern Ireland

\section{Current Bibliography}

Odwin HOFFRICHTER, Institut für Biologie I, Albert-Ludwigs-Universität Freiburg, Hauptstrasse 1, D-79104, Germany

\section{Treasurer}

Trond Andersen, Natural History Collections, Bergen Museum, University of Bergen, Muséplass 3, NO-5007 Bergen, Norway

CHIRONOMUS Newsletter on Chironomidae Research (ISSN 0172-1941) is published yearly in October. Submission deadline for contributions is July 1.

Contributions to CHIRONOMUS Newsletter on Chironomidae Research should be submitted per e-mail to: Torbjørn Ekrem: Torbjorn.Ekrem@vm.ntnu.no or Peter H. Langton:

PHLangton@kylebegave.fsnet.co.uk. Please use the following formatting: Text in 12 point Times New Roman, first page must include title, name, address and email address of all authors. Headings should be bold faced. Cite relevant references in parentheses without comma between name and year [ex. (Langton 1991)]. List all references alphabetically in the format of the Current Bibliography at the end of the manuscript. Tables can be included directly in the text. Text should preferably be submitted as MS Word or rtf files. All figures should be supplied separately as tiff or jpg files.

Would you like to see your picture on the front page? Please send us your favourite midge photograph or drawing (Torbjorn.Ekrem@vm.ntnu.no). 


\section{Dear colleagues}

What is the future for Chironomidae taxonomy? Grand projects to document all life on earth have emerged over the last couple of years. The Encyclopedia of Life (www.eol.org) aims to provide a free online resource to high quality information on all organisms while the Barcode of Life Initiative (www.dnabarcodes.org) takes advantage of molecular characters to catalogue, identify and discover biodiversity. Both these scientific endeavours have received substantial funding and aim to be unique resources for information on biodiversity and biology - but both are dependent on expert taxonomic knowledge to be successful. The taxonomic impediment was formally recognised by the parties of the Convention on Biological Diversity as early as 1998 with the establishment of the Global Taxonomy Initiative (www.cbd.int/gti). Although some countries have initialised research programmes to meet the demand for more taxonomist in the future (e.g. the PEET program in USA), the world has so far not seen substantial increase in the number of professional taxonomists. So, who will provide the taxonomic knowledge needed for success in initiatives like BOLI and EoL? Well, for the so called charismatic mega-fauna the information needed is more or less readily available. For the truly diverse groups such as insects, however, there are substantial holes in the taxonomic knowledge. Unless more nations take documentation and description of biodiverstity more seriously and develop appropriate research programs in taxonomy, we will be unable to document life on earth fast enough to properly detect the diversity loss caused by anthropogenic environmental change.

Knowledge of chironomid diversity and taxonomy is relatively advanced compared to some other insect groups, but the number of active Chironomidae taxonomists is on a steady decline. This, despite the fact that knowledge of chironomid taxonomy and distribution has numerous uses, and perhaps is more important than ever given the increased interest in documenting past and recent climate change. Chironomid taxonomists should become better at recruiting new students and assure that committed individuals are allowed further development and work in chironomid taxonomy. To do so, we should take advantage of our extensive network and create international projects that include joint field work, workshops, courses and increased student mobility - all attractive elements for graduate students as well as senior researchers. If we are successful, chironomid taxonomy will have a bright future in modern biodiversity and environmental science. Please use the CHIRONOMUS Newsletter on Chironomidae Research, the Chironomid Home Page (insects.ummz.lsa.umich.edu/ ethanbr/chiro/) and the chironomid mailing list (Chironomidae@lists.vm.ntnu.no) to spread your news on ongoing research projects and requests for cooperation.

In this number we present current research articles on subfossil chironomids from 18 lakes in Finland, chironomid communities in Lake Baikal, chironomids new to France, chironomids from the Yucatan peninsula in Mexico and behavioural observations of an arctic chironomid species in addition to news, short communication and the Current Bibliography. We hope you find it interesting reading!

Torbjørn Ekrem Museum of Natural History and Archaeology, Norwegian University of Science and Technology, Norway. Email: Torbjorn.Ekrem@vm.ntnu.no 


\section{A BRIEF BIOGRAPHY OF MARY FRANCES SMITH SUBLETTE JUNE 22, 1927-JUNE 9, 2007}

Mary Frances was born in East Texas to Pleas and Arkie Odelphia (Arkadelphia) Wilbanks Smith. Her heritage can be traced back to the original Plymouth colony in present day Massachusetts. When Mary was a preschool child, the Smiths moved to the high plains in West Texas, where the vistas of prairie beauty fostered a love of wildflowers that remained deeply ingrained for Mary's lifetime. Her other enduring passion was needlework, beginning as a young girl when her paternal grandmother gave her a box of threads and showed her how to do simple stitches.

Her mother, who was orphaned as a child, struggled to become a school teacher; she impressed upon her four daughters the necessity of a good education. Mary and her sisters went to college, and Mary herself was later instrumental in establishing educational goals in several young persons, including her own four children, who between them hold 11 college degrees. Mary received her bachelor's degree in 1948 from Texas Tech in Lubbock. She entered intending to pursue journalism, until she took a biology course with Dr. Harold Hefley. She found it so fascinating that the professor set up a microscope for her in his lab. As she later confided, "those beautifully colored slides" motivated her switch to a biology major. When Mary was a junior, Dr. Hefley arranged for her to get a scholarship to the Rocky Mountain Biological Laboratory at Crested Butte, CO. The student body and faculty, while small, were cosmopolitan. For the first time Mary realized she had a distinct regional accent, and she was teased rather unmercifully about it, an anecdote she loved to tell in later years.

Upon completion of her baccalaureate, Mary was persuaded by Dr. Hefley to turn down an assistantship she was offered; he arranged a counteroffer from his alma mater, the University of Oklahoma, where she eventually (after taking time off for beginning family) received her Master's degree in Zoology in 1955. Meanwhile, Dr. Hefley had moved to the University of Arkansas and was thesis advisor to James (Jim) Sublette. Dr. Hefley likewise steered Jim toward OU, arranging a doctoral fellowship for him there. As Jim was leaving for Norman, Dr. Hefley said to him, "There is a nice girl at OU who was a former student of mine at Texas Tech. You should look her up.” Thanks to Dr. Hefley, Jim and Mary's lives became inextricably intertwined; they were married on June 24, 1950.
Mary is survived by Jim, four married children, and eight grand-children. Their children are Ned, a classical guitarist and ethnomusicologist, author of a major book on the history of Cuban music; Elizabeth, an assistant professor and researcher in biochemistry and psychiatry at Columbia University; Mark, a former physician who now owns arts galleries in Tucson and Santa Fe; and Amy, currently a Ph.D. student at Arizona State University.

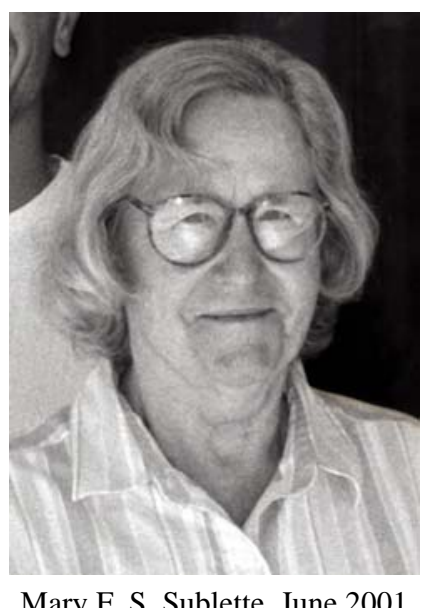

In addition to her accomplishments as wife, mother, and grandmother, Mary always worked together with Jim on his studies in chironomid taxonomy, co-authoring several publications as well as a monograph of the Fishes of New Mexico. She has been honored by having one genus and several species of midges dedicated to her, as well as joint dedications with Jim. A Festschrift dedicated to Mary and Jim was published in the Journal of the Kansas Entomological Society in 1998. Mary’s interest in flowers found expression in a botanical guide she co-authored, "Roadside Flowers of New Mexico.” Mary was also a published poet, with many of her poems mentioning her beloved prairie flowers. Perhaps her most inspired heritage, however, is the collection of embroidery she created. An event which changed her life was a summer with Jim at Bergen, Norway in 1981, where she was inspired by a small freehand embroidery she saw there. Afterward, Mary began experimenting with original designs on various linen fabrics and high-quality embroidery threads. Mary's breathtaking "needle paintings," as they became known, depict biologically correct wildflowers, insects, and fish, in a naïve style of large central figures in brilliant colors, often on a solid embroidered backdrop. Mary never allowed 
her works to be sold, insisting they were a legacy for her children and grandchildren.

Mary took joy in her husband and their family to the last moment of her life. Her diligence in Zoology and artistic creativity gave added beauty and meaning to the world. I think Mary's goals in life were well satisfied.

James E. Sublette

Scottsdale, $A Z$

\section{KAARE AAGAARD 60 YEARS}

Professor Kaare Aagaard has celebrated his 60 years anniversary this year, and we would like to take this opportunity to congratulate him and recapitulate some of his academic life and scientific accomplishments.

Kaare was born in Trondheim on January $13^{\text {th }}$ 1947 and went to school in the same town. Just before he started gymnasium (high school) in 1963 he collected his first butterfly, and in the following years he became increasingly interested in all kinds of insects: Butterflies, dragonflies, thrips, bugs, earwigs and beetles were all collected and identified. This general interest in various insect groups went on as Kaare started his studies at the University of Trondheim a couple of years later, and he published several papers in the Norwegian Journal of Entomology on all these groups. He actually also started working on several graduate works on thrips, aphids and bugs before he tried to encourage a friend to start working on our fascinating group, the chironomids. His friend remained unimpressed, but Kaare managed to convince himself that nonbiting midges was the way forward and graduated in 1973 with a cand. real degree on the Tanypodinae of the lake Målsjøen including a study of morphological changes caused by nematode parasitism (Aagaard 1974, 1978).

After his graduation, Kaare continued working with Chironomidae and spent 3 months with Ernst Josef Fittkau and Friedrich Reiss in Plön. The major focus was still directed towards the subfamily Tanypodinae, but at the Max Planck Institute Kaare developed taxonomic expertise in other chironomid taxa as well. This knowledge undoubtedly has been useful in the many freshwater mapping and monitoring projects Kaare has been part of. About 35 scientific journal papers and book chapters has Kaares name on them, and he has contributed to more than 100 scientific reports, some of which are referenced below.

Over the years, Kaare has focused his research on various aspects of both freshwater ecology and conservation biology. He has been an advisor on numerous boards and also Norway's representative in the European Council's Bern Convention on the conservation of European wildlife and natural habitats. Kaare has also been a key player in the development of the Norwegian red lists. He has been curator of entomology both in Trondheim and in Tromsø, an advisor in the Norwegian Directorate for Wildlife, and head of Trondheim division of "Økoforsk" the predecessor of the Norwegian Institute for Nature Research where he later spent almost 15 years as a scientist and administrative leader. Kaare is currently curator and head of department at the Section of Natural History, Museum of Natural History and Archaeology in Trondheim.

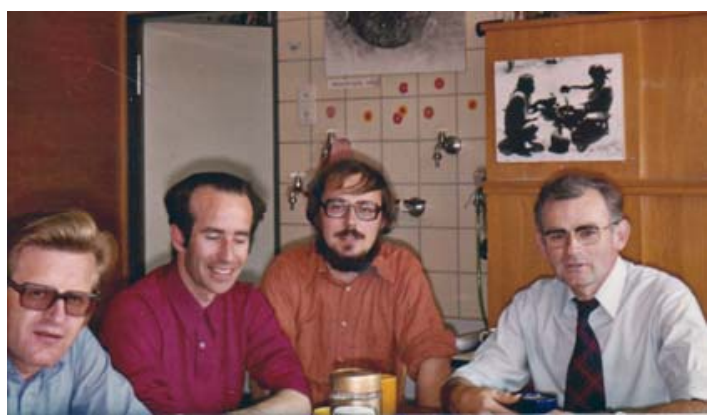

Plön 1975: Friedrich Reiss, Declan Murray, Kaare Aagaard and Ernst Josef Fittkau.

We congratulate Kaare with his anniversary and wish him all the best for the years to come.

Torbjørn Ekrem

\section{Selected publications on Chironomidae}

Aagaard, K. 1974. Morphological changes caused by nematode parasitism in Tanypodinae (Diptera, Tanypodinae, Chironomidae). Norsk Ent. Tidsskr. 21: 11-14.

Sendstad, E., Solem, J.O., Aagaard, K. 1977. Studies of terrestrial chironomids (Diptera) from Spitsbergen. - Norw. J. Ent. 24: 91-98. 
Aagaard, K. 1978. The chironomids of lake Målsjøen. A phenological, diversity, and production study. - Norw. J. Ent. 25: 21-37.

Aagaard, K. 1978. The Chironomidae of the exposed zone of Øvre Heimdalsvatn. Holarct. Ecol. 1: 261-26.

Aagaard, K. 1979. Eukiefferiella sivertseni n.sp. from Norway. - Ent. Scand. Suppl. 10: 95-97.

Aagaard, K., Engen, E. 1980. Species diversity of Chironomid Communities. - Acta Univ. Carolinae Praha 12: 5-12.

Aagaard, K., Sivertsen, B. 1980. Chironomidae. In: The benthos of lake Huddingsvatn Norway after five years of mining activity, Pergamon Press, pp. 247-254.

Aagaard, K. 1982. Profundal chronomid population during av fertilization experiment in Langvatn, Norway. - Holarct. Ecol. 5: 325331.

Koksvik, J.I., Aagaard, K. 1984. Effects of rotenone treatment on the benthic fauna of a small eutrophic lake. - Verh. Internat. Verein. Limnol. 22: 658-665.

Aagaard, K. 1986. The chironomid fauna of North Norwegian lakes, with a discussion on methods of community classification. Holarct. Ecol. 9: 1-12.

Aagaard, K., Olsen, A. og Solem, J.O. 1987. Chironomids of Blesbekken, an alpine tundra stream at Dovrefjell national park, Norway. Ent. scand. Suppl. 29: 349-354.

Aagaard, K. 1992. Ordination or typology - The search for a stable classification of running water communities. - Neth. J. Aqua. Ecol. 26(2-3): 441-445

Aagaard, K., Schartau, A.K.L., Hanssen, O., Lierhagen, S., Willmann, B.H.1994. Effects of cadmium on population and community structures in littoral zone of a boreal lake: An experimental study using limnocorrals. Verh. Internat. Verein. Limnol. 25: 20212025.

Aagaard, K., Dolmen, D (eds). 1996. Limnofauna Norvegica. Tapir, Trondheim, 310 p.

Aagaard, K., Solem, J.O., Nøst, T., Hanssen, O. 1997. The macrobenthos of the pristine stream, Skiftesåa, Høylandet, Norway. Hydrobiologia 348: 81-94.

Schartau, A.K.L., Aagaard, K. \& Lierhagen, S. 1997. Cycling of cadmium in freshwater following experimental contamination. Verh. Internat. Verein. Limnol. 26: 382-387.

Solem, J.I., Solem, T., Aagaard, K. \& Hanssen, O. 1997. Colonization and evolution of lakes on the central Norwegian coast following delaciation and land uplift 9500 to 7800 years B.P. - J. Paleolimnology 18: 269-281.

Ødegaard, F., Diserud, O., Engen, S., Aagaard. K. 2000. The Magnitude of Local Host Specificity for Phytophagous Insects and its Implications for Estimates of Global Species Richness - Conservation Biology 14: 11821186.

Lushai, G., Fjellstad, W., Marcovitch, O., Aagaard, K., Sherratt, T., Allen, J.A., Maclean, N. 2000. Application of molecular techniques to non-lethal tissue samples of endangered butterfly populations (Parnassius apollo L.) in Norway for conservation management - Biological Conservation 94: 43-50.

Aagaard, K. Hindar, K., Pullin, A.S., James, C.H., Hammarstedt, O., Baldstad, T., Hanssen, O. 2002. Phylogenetic relationships in brown argus butterflies (Lepidoptera: Lycaenidae: aricia) from north-western Europe. Biological Journal of the Linnean Society 75: 27-37.

Diserud, O.H. \& Aagaard, K. 2002. Testing for changes in community structure, based on repeated sampling. - Ecology 83: 224- 230.

Sandlund, O.T., Aagaard, K.H. (eds). 2004. The Atna River: Studies in an Alpine-Boreal Watershed. Kluwer Academic Publishers, Dordrecht/Boston/London. Developments in hydrobiology 177, 208 p.

Sandlund, O.T., Aagaard, K.H. 2004. Long term monitoring and research in an alpine-boreal watershed: Atndalen in perspective. Hydrobiologia 521: 203-208.

Aagaard, K.H., Solem, J.O., Bongard, T., Hanssen, O. 2004. Studies of aquatic insects in the Atna River 1987-2002. - Hydrobiologia 521: 87-105. 


\section{SEPP HAS TURNED 80!}

Professor Dr. Ernst Josef Fittkau turned 80 this year and celebrated his birthday the $22^{\text {nd }}$ of July. We would like to congratulate him on this anniversary and wish him all the best on the way to 90 !

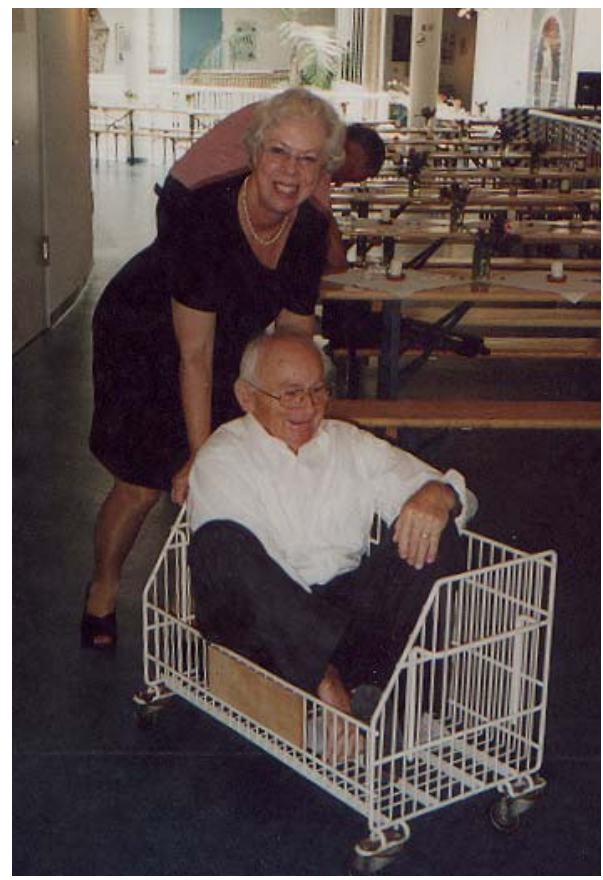

Touring the ZSM: Elise and Sepp, 2002.

Much has already been written on Sepp's numerous accomplishments over the years (Anonymous 1992, Spies 2002), and we do not wish to repeat what others have done so well before us. However, Fittkau continued his involvement in Chironomidae research also after his 75 years anniversary, and has been involved in several scientific publications (see below). Angela Sanseverino, his last $\mathrm{PhD}$ student so far, graduated in 2006.

Prof. Fittkau has truly moved chironomid research forward, but he has also been active and well noticed in many broader fields like zoology, taxonomy, biology and limnology. If we were to elaborate on his contributions to the scientific community in all fields, we would fill many pages - pages from an impressively rich life, both professionally and socially. We would like to especially mention the latter here. His professional achievements are recognized all over the world, but his personal commitment, affectionate and charming being has been a privilege especially for those of us who have been lucky enough to spend some time with Sepp.

Fittkau was and is always in the most sincere way open and interested to get to know new people from different cultures. With his first welcome "Grüss Sie”, "Freue mich”, "Nice to meet you” or "Muito prazer" he includes us in his world rich in experience and fascinating stories. What a privilege it is to listen to stories from his time in the Amazon, about his trips into the rainforest, his experiences and friendships with the native population and his excursions on so many streams with the canoe. Or to be entertained by stories from his work in Schlitz, his field work along the River Fulda, his time in Plön, the building of the current Zoologische Staatssammlung in Munich, and of all the interesting scientists he knew: Thienemann, Illies, Müller, Sioli, Brundin and many, many others.

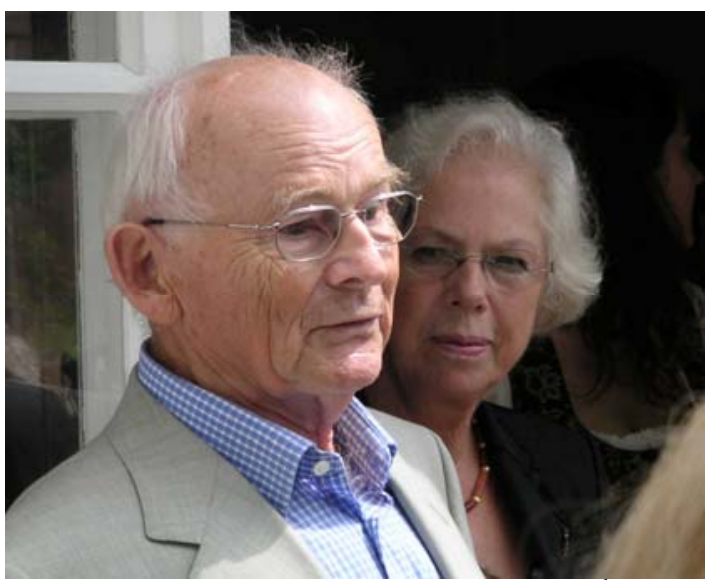

Sepp and Elise in Icking, celebrating Sepp's $80^{\text {th }}$ anniversary on July 22, 2007.

Fittkau is an inspiration to us all, in particular to those of us who are just starting our career. We have all had the privilege of sharing parts of our lives with Sepp and have appreciated and enjoyed his encouragement and support. Even in his hardest times, Sepp found kind and heartening words for others. His generosity became part of our lives, our work and also helped us make important personal decisions. For this we would like to thank him from the bottom of our heart and wish him a joyful time together with his family and friends.

Angela Sanseverino, Elisabeth Stur, Irene Wagensonner, Jochen Gerber, Maria Conceição Messias, Martin Spies, Nicola Reiff, Rodulfo Ospina Torres, Sofia Wiedenbrug, Torbjørn Ekrem, Wolfgang Riss

\section{References}

Anonymous 1992. Prof. Dr. Ernst Josef Fittkau sein Leben und Werk. Pp. 7-23 in: Chronik 
der Zoologischen Staatssammlung München. Festschrift zur Verabschiedung des Direktors der Zoologischen Staatssammlung München Prof. Dr. Ernst Josef Fittkau 1976-1992. Spixiana Suppl. 17.

Spies, M. 2002. Professor Ernst Josef Fittkau - 75 years, 50 years for chironomid research. Chironomus Newsletter on Chironomidae Research 15: 2-13.

\section{Ernst Josef Fittkau's publications after 2001}

Sanseverino, A.M., Fittkau, E.J. 2002. (printed 2003) Marauia group: a new species group in the genus Tanytarsus van der Wulp, 1874, from the Neotropics (Diptera, Chironomidae). - Studia Dipterologica 9: 453-468.
Sanseverino, A.M. \& Fittkau, E.J. 2006. Four new species of Tanytarsus van der Wulp, 1874 (Diptera: Chironomidae) from South America. - Zootaxa 1162: 1-18.

Stur E., Fittkau E.J., Serrano M.A.S. 2006. Male, female, pupa and larva of Parapentaneura bentogomensis gen. n., sp. n., a new Tanypodinae from Brazil (Diptera, Chironomidae). - Zootaxa 1384: 59-68.

Sanseverino, A.M. \& Fittkau, E.J. 2007.Taxonomy of Caladomyia alata (Paggi, 1992) and Caladomyia tuberculata (Reiss, 1972), new combinations (Diptera: Chironomidae). In Andersen, T. (ed.) Contributions to the Systematics and Ecology of Aquatic Diptera - A Tribute to Ole A. Scether. The Caddis Press, p. 265-273.

\section{REPORTS FROM THE $16^{\text {TH }}$ INTERNATIONAL CHIRONOMID SYMPOSIUM IN FUNCHAL, MADEIRA, JULY 25-28, 2006}

It is probably safe to say that the $16^{\text {th }}$ International Chironomid Symposium in Funchal was a great success. CHIRONOMUS Newsletter has received a few detailed reports and thoughts on the conference. Thanks to all of the contributors.

\section{The 16th International Chironomid Symposium, Funchal, Madeira, 25-28th July, 2006}

My memories of the conference are of the excellent organisation including the social program of events organised by Samantha Hughes and her team that really added to the conference. I will discuss these later to do them justice, but first I will review my initial impressions of the conference as I was told to mention the fact that we did go there to do some work!

The symposium was held at the Caza da Luz Museum where we eagerly arrived on Tuesday morning to hear the Thienemann Honorary Lecture given by Ian Walker on "Chironomids: the past, present and the future." This lecture provided a personal insight into how chironomids can be used as indicators of past environmental change. The topic offered a good introduction for the Palaeolimnology session that followed on various aspects of using chironomids as indicators of past climate and ecological change. Examples were provided by Donna Francis illustrating climate change in the Arctic, Stephan Engels in
Finnish Lapland, Aaron Potito in Sierra Nevada, California and Barbara Lang in England. Steve Brooks and Thora Hrafnsdottir presented evidence of ecological change in Scotland and Iceland. After lunch there were two sessions on the use of chironomids in Toxicology and Biomonitoring. Len Farrington compared and studied the significance of Chironomidae emergence in Pennsylvania. There was a poster session after these presentations which provided a good opportunity to present your work to a diverse audience. Topics included the use of chironomids in palaeolimnology, ecology, taxonomic studies and DNA barcoding. The first day drew to a close with a Madeira de Honra and welcome reception kindly hosted by the Mayor of Funchal in the ornate surroundings of the Town hall.

The theme of Wednesday's presentations provided an interesting perspective into the ecology and taxonomy, morphology and systematics of chironomids. Oliver Heiri provided an in depth study into the distribution of Chironomidae from surface sediments in Switzerland. An exciting new development was the DNA barcoding of Chironomidae discussed 
by Torbjørn Ekrem. This technique has the potential to be a useful tool for taxonomy and freshwater biomonitoring. After lunch there was a session on Physiology and Physiological Responses that provided remarkable insights into experimental approaches. Examples included determining the respiration rates and distribution of midges in British Columbian lakes (Klaus Brodersen) and the respiration rate and temperature of cold stenotherms (Valeria Lencioni). The second poster session followed these presentations which provided another opportunity to gain further insight into the various aspects of chironomid research currently undertaken.

The symposium banquet was held on Wednesday night at Quinta Magnólia generously offered by the government of Madeira. The outdoor banquet certainly lived up to its surroundings which were set in a beautiful garden. The scenic landscape was matched by the presentation of the food which was lavishly decorated.

On Thursday the final session was on Biogeography and Biodiversity. The presentations given by Susan Gresens and Declan Murray discussed the occurrence and diversity of chironomids in various habitats and locations from as far apart as Minnesota and the Azores/Madeira. The final poster session that followed these presentations offered a last chance to discuss the various projects with the different authors. There was a debate after lunch which included an open forum discussing the various methods of accessing different databases and how to make these more accessible. Peter Cranston gave a demonstration of his new identification key and he generously provided copies to interested parties.

The conference drew to a close with a cocktail party and informal talks on Thursday evening at the Caza da Luz Museum. The first talk was given by Miguel Sequeira from the Department of Biology at the University of Madeira on "Madeira plant diversity and vegetation types.” The second talk was given by Frank Zino on "The rediscovery of Zino's Petrel Pterodroma madeira” which was thought to be extinct on the island. These talks provided a wonderful background to the flora and fauna of the island that many of us hoped to enjoy the next day on various fieldtrips.

The fieldtrips on Friday included a Levada trek, a mountain hike and a boat trip to the Desertas Islands, a nature reserve situated south-east of Madeira. I chose the Levada trek guided by Miguel Sequeira following the Serra do Faial Levada through the Laurissilva forest which is a world heritage site. It was amazing to see the irrigation canals (levadas) built by the first settlers to transport water to inaccessible farmland. The oldest levadas were built about 400 years ago (though not the section we went on) to transport water from the wetter north of the island to the drier southern part. This walk provided the perfect opportunity for collecting midges and as we got into the forest more nets came out. The scenery along the route was spectacular particularly as we walked further into the forest and stopped at several view points. The day ended well with dinner at a sea front restaurant for many of us.

The last day was dedicated to a taxonomy workshop held at the University of Madeira where we could bring our problem taxa to be identified. This was a very useful aspect of the trip as there were many people available to help and discuss our problems with. We were taken to a traditional restaurant for lunch where we had the local delicacy espetada (skewered beef). The next day seemed to come too soon as it was time to go home after a great week on the island. I would like to thank Samantha and the organising committee for arranging an excellent conference and their wonderful hospitality.

Wing Wai Sung, Department of Geography, Loughborough University.

\section{A mediterranean view of the Madeira symposium ...}

Coming from Barcelona ...flying to Madeira Island. The objective was to participate in my first “International Chironomid Symposium”. When I arrived, my first feeling was that all the delegates know each other, obviously a confirmation that the "world of chironomidology" is small. In a few days the entire group created a friendly atmosphere, and all new people were kindly received. It was a familiar meeting, where all the participants shared their work on Chironomidae, focusing on different aspects: paleo, ecology, taxonomy, genetics and biogeography. For me, one of the best things was to get to know the most important chironomidologists that write the taxonomic keys that we use in our identifications, and it was a privilege to participate in the workshop, sharing our doubts with students and experts.

Apart from the professional exchanges, we had the opportunity to discover a fantastic island in a Macaronesian world, searching for Clunio during our free-time, trekking in the deep green of Madeira and eating typical Portuguese food. A 
nice experience sharing the words, doubts, questions of our research that are difficult to understand for non-chironomidologists. Thank you!

Tura Puntí, Department of ecology, University of Barcelona, Spain.

\section{Madeira Symposium Memories}

When I recall the Madeira Symposium I can't find any bad feelings about it. The Symposium was very well organised and took place in a nicely warm Madeira climate, which I really enjoyed. In my eyes, the best thing was that there came together people interested in chironomids (including the greatest specialists) from all over the world and since there were not too many people, in contrast to most international conferences, it was possible to meet everyone and have a talk with them. For me it was the best conference I have ever attended and I hope that I will be able to do so the next time as well.

Vit Syrovatka, Institute of Botany \& Zoology, Masaryk University.

\section{The Madeira Symposium}

From my first contribution to Chironomid Symposiums I can review this symposium with just two words "great experience". I can only guess, like most of the students present there I presume, how much effort has gone into preparing it. It was a high quality symposium on both practical and scientific sides. The scientific themes were very diverse including all aspects of chironomid research, highly rewarding for $\mathrm{PhD}$ students who spend the major part of their research working on one topic. Such symposiums allow us to see the diversity of chironomidology research: taxonomy, ecology, paleolimnology, biodiversity and genetics. The other positive element was the human scale of the symposium, making it easy to meet and chat with all the scientists and also to assist at all the oral presentations.

Not only did the symposium act as a centre for the exchange of ideas at an international level, I can say also that it's a great opportunity to meet scientists from all over the world and to weave a web of contacts for further collaboration which is very helpful for us $\mathrm{PhD}$ students to prepare postdoc projects for subsequent collaborations.

Alain Maasri, Université Paul Cézanne - IMEP Marseille.

\section{The Madeira Symposium}

I enjoyed many aspects of the Madeira Symposium; strolling along the sea front, sipping Madeira in the old-world elegance of the Town Hall, the delicious food at the Symposium dinner and, of course, the stimulating talks. But the 'best bit' was the enthusiasm and friendliness of the delegates. Students and experienced researchers were eager to discuss their research, share experiences and offer advice. Their enthusiasm extended beyond narrow research topics with palaeolimnologists interested in modern ecology and distribution data and modern ecologists examining the fossil assemblages. This stimulating atmosphere of mutual interest and cooperation was exemplified by the workshop where discussions ranged from identification of problem taxa to fieldwork logistics. I would like to thank everyone that offered advice or sent research material, particularly Peter Langton for sending copies of his pupae identification key. I hope I can share my research at a future Symposium.

Angela Self, Department of Entomology, Natural History Museum, London.

\section{THE 8TH EUROPEAN SUBFOSSIL CHIRONOMID WORKSHOP, REYKJAVÍK}

\section{7-8TH MAY 2007}

Since first meeting in Helsinki in 1997, European subfossil chironomid workers have held workshops every year or two to discuss progress and problems. More recently, many of these meetings have been attended by our North American colleagues (or 'dead headers'), adding greatly to the discussions. This was the first time we had met as a community on 'neutral territory', i.e. the middle of the North Atlantic. Iceland is an exceptional place to visit, as was demonstrated on an introductory field visit for the majority of those attending the workshop. Our hosts, Jón Ólafsson and Thora Hrafnsdóttir took us on a tour around the SW peninsula, noting the geothermal 
geology, wildlife (fulmars, kittiwakes, and gannets for the bad birdwatchers) and a splendid crater lake of $\mathrm{pH} 2$. At the end of the fieldtrip we were treated to a well earned soak in the Blue Lagoon to prepare us for the discussions over the next two days.

Palaeoenvironmental reconstructions from analyses of subfossil head capsules are now well established in mainstream and specialist literature, and are often incorporated as key proxies in scientific debates at the forefront of research agendas. However, as with any technique there is a need to constantly discuss progress and problems, and these workshops provide the ideal vehicle with which to undertake this. The discussion did not shirk from debating key, sometimes controversial issues, and while much of the questioning/debating was critical, it was most certainly inclusive, fair and good-humoured. Workshops should be a focus on discussion and debate, and this one succeeded admirably. The theme of the workshop was on the Cricotopus/Orthocladius dilemma, and whether we can split these genera successfully within our subfossil taxonomy. It has been traditional within these workshops to always devote a large chunk of time to taxonomic debates, and while this workshop was no different (we all recognise that taxonomy underpins our environmental reconstructions) we also managed to debate equally important aspects of our research, especially those related to the numerical techniques we use and ecological complexity within palaeoecology.

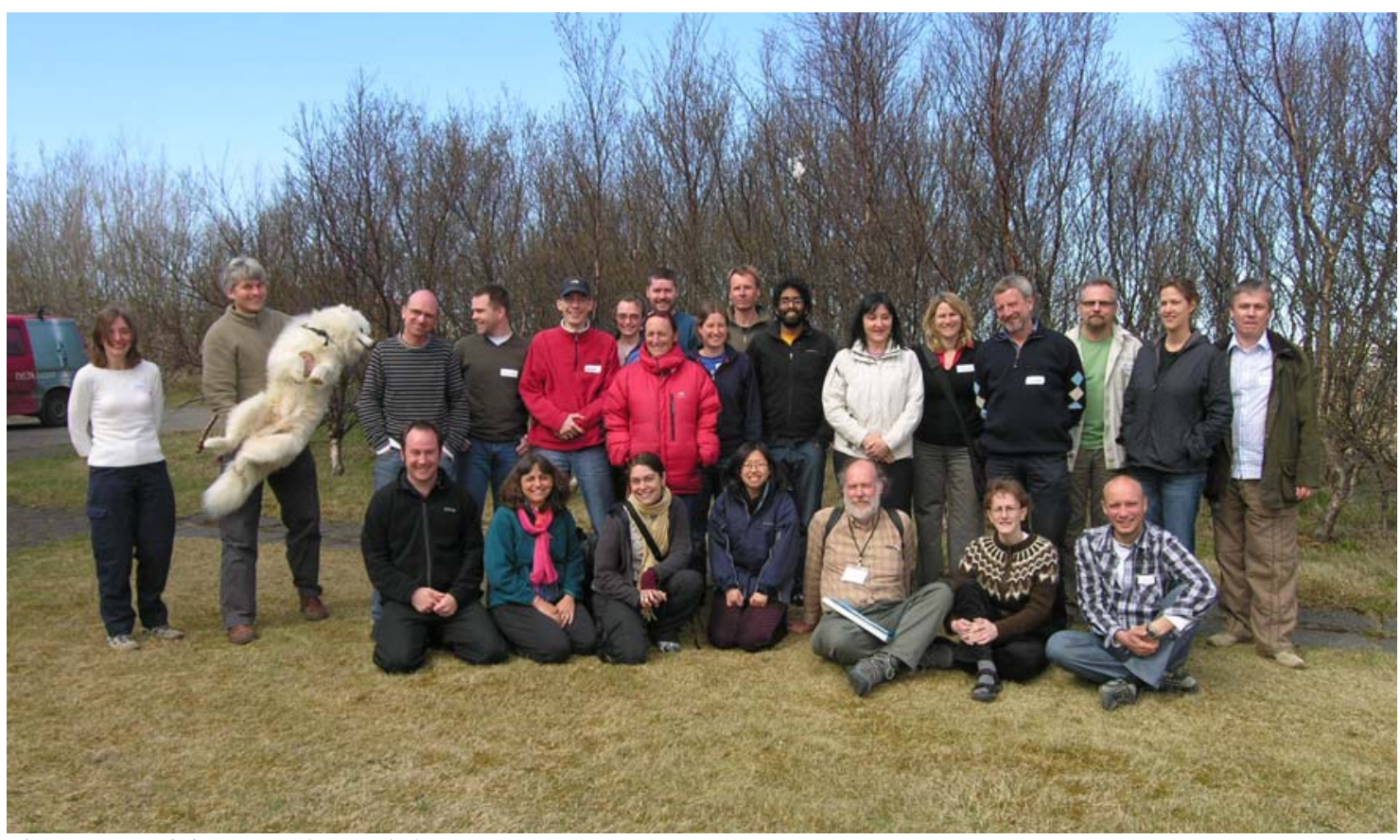

Figure 1. Participants at the workshop

The workshop presentations were focused around 3 main themes: environmental reconstructions (mainly climate based), ecological functioning, and taxonomy. The reconstruction talks focused on a range of sites and timescales. Records from the last 1-2 millennia were discussed by Naomi Holmes, Yarrow Axford, Elizabeth Thomas (all Icelandic sites) and Nicholas Rolland (a site in Nanavut, Canada), whereas David Porinchu considered records covering the last 150 years from western USA. The Arctic was a key theme of this meeting, perhaps no surprise as this workshop followed the Arctic workshop, held in Skaftafell, SW Iceland, two days previously, and presentations from Gaute Velle, Donna Francis, Isabelle Larocque and Marie-Claude Fortin all discussed work from projects they are currently working on in this region. It was not all Arctic science though, as Craig Woodward showed us his 'Diptera down-under', discussing his research on New Zealand sub-fossil chironomids as indicators for long-term environmental change. Many of the subfossil sequences presented were analysed in terms of quantitative temperature reconstructions. Steve Brooks assessed how reliable these chironomid-inferred temperature reconstructions are in terms of the late-glacial and Holocene in NW Europe. The main consensus was that late-glacial records seemed to agree well although some regional differences exist, whereas there is far less agreement between Holocene temperature reconstructions. This is thought to be 
mainly due to the range of lake developmental pathways that exist, for example changing $\mathrm{pH}$ throughout the Holocene will also influence chironomid communities. Discussion focused on whether we are actually at the limit of what we can achieve regarding the magnitude of error estimates for Holocene thermal changes, and that $1-2{ }^{\circ} \mathrm{C}$ errors were actually quite good when we consider the complex ecological functioning underlying chironomid response to environmental change. These points withstanding, there are clearly some Holocene temperature reconstructions that appear to work well and show good agreement with other (quantitative) proxy evidence.

The workshop highlighted the need to improve our understanding of the role of chironomids in ecological functioning, as well as generating autoecological data. Klaus Brodersen illustrated this point succinctly by presenting new data on Corynocera ambigua ecology. He combined oxygen respiration experiments on the larvae with stable isotope data in order to try to understand the ecological mechanisms through which this taxon is governed. The results suggested that these processes are complex, and Klaus noted that while we now have good data for this taxon, we still have many other taxa for which we require experimental data. Other talks relating to ecological functioning focused on the role of macrophytes and chironomid communities in the UK (Peter Langdon), lake-climate interactions (Wing Wai Sung), and analyses of the chironomid community structure in Icelandic lakes (Thora Hrafnsdóttir). Discussion focused on the ecodynamics of Lake Myvatn (led by Árni Einarsson) and an understanding of ecological scaling and complexity in palaeoecology (led by Gaute Velle and Klaus Brodersen), where the challenge of validating and interpreting the results of inference models was discussed. One conclusion was that when using inference models, taxon optima can change depending on what other environmental factors change, as well as what other taxa are present; or in other words palaeoecological simplicity may need to be considered more carefully in the face of ecological complexity.

Taxonomic discussions did, as usual, form the brunt of much of the discussion, and were led by (in no particular order) Jón Ólafsson, Thora Hrafnsdóttir, Ian Walker and Oliver Heiri. New taxonomic guides have recently been produced, including Larocque and Rolland (2006), Brooks et al. (2007), and a Provisional Interactive key to Larval Chironomidae by Pete Cranston (available on CD from the author at: pscranston@ucdavis.edu), which stimulated much debate. This was an important discussion, for both new and more experienced chironomid palaeoecologists, and a number of key points were identified as important to consider:

- Taxonomy provides a unique and stable name for every taxon and it underlies studies in ecology, palaeoecology, biogeography etc. Results (e.g. reconstructions) are dependent upon the correct use of taxonomy, i.e. correct identifications. We want as high a resolution in our taxonomic data as possible, however, we should be conservative in our identifications, and to guard against oversplitting.

- Correct taxonomy is especially important in terms of retrieving the correct ecological information about chironomid taxa from the literature.

- Consistent taxonomy is important for training set data and core data in order to obtain sound reconstructions.

- The term 'morphotype' or 'type' is used to refer to a taxon with a particular morphology, but there may be more than one species included and these are indistinguishable based on subfossil features.

- At present much of the fossil taxonomy is based on fossil examples, not reared/living larvae. Ways to link the larvae to the adults would be through rearing and DNA methods.

- In future identification guides we could add photos of reared larvae next to photos of fossil larvae. There are few reared specimens in collections, so these may not be representative of the species (thus we have little or no information on intra-specific variation). Also, the photos of fossil larvae are still needed because these are more representative of what palaeoecologists see under the microscope.

- In our publications it is important to cite the key used or the description of a taxon, so others can refer to this in the future as well as to prevent misconception in the future. We should also take photographs, and record (publish if possible) ‘odd’ specimens found.

One important topic of debate, and the workshop theme, was the possibilty of differentiating Cricotopus/Orthocladius/Paratrichocladius (led by Oliver Heiri). It is impossible to do this at the generic level if we cannot make a species-level diagnosis (on fossil material), but some species 
(or at least morphotypes) are distinctive. Numerous morphotypes that can be consistently distinguished are described in the new taxonomic guide by Brooks et al. (2007). The guide provides an essential standard for our community at the present time. One problem is that different instars may falsely appear to be different morphotypes (e.g. for Pseudodiamesa) and it is essential to keep an eye out for this. The "dilemma" is that we must choose between potentially committing "type II" errors (in which we do not recognise differences that actually exist) and "type I" errors (in which we see differences that do not actually exist). Some suggestions as how to proceed included:

1. Test existing datasets at high taxonomic resolution. Send resulting ideas, pictures, etc amongst our community.

2. Check the literature for ecological notes regarding different taxa.

3. Check for co-existence with other taxa - a source of clues regarding the ecology of morphotypes.

4. Check trophic optima vs. temperature optima.

5. Test model performance at different taxonomic resolutions. This will save time if splitting does not add information. Note that lumping may yield more precise but less accurate models. Splitting may be less worthwhile for transfer-function based reconstructions, but could be very useful for palaeoecology (studies of diversity, palaeogeography, etc.).
Overall this was an excellent meeting, and as a research group we got to grips with many of the key issues that affect our discipline, much of which is reported above. Warm thanks go to Jón Ólafsson and Thora Hrafnsdóttir who organised the workshop, the Institute of Freshwater Fisheries, where the meeting was held, and to Hilmar Malmquist who organised an excellent reception at the Natural History Museum of Kopavogur where we sampled such delicacies as dried fish and rotting shark (hákarl) washed down with shots of brennivín (translation: Black Death). Delicious.

\section{References}

Brooks, S.J., Langdon, P.G. and Heiri, O. 2007. The identification and use of Palaearctic Chironomidae Larvae in Palaeoecology. QRA Technical Guide No. 10, Quaternary Research Association, London. 276pp.

Larocque, I. and Rolland, N. 2006. Le guide visuel des chironomids sub-fossiles, du Québec à l'île d'Ellesmere, INRS rapport de Recherche R-900.

Peter Langdon, University of Southampton, UK. Naomi Holmes, University of Exeter in Cornwall, UK.

Stefán Már Stefánsson, Natural History Museum of Kopavogur, Iceland.

Elísabet Hannesdóttir, Institute of Freshwater Fisheries, Iceland.

Yarrow Axford, University of Buffalo, USA.

\section{NEWS FROM CHIRONOMID RESEARCH IN INDIA}

\section{University of Burdwan}

The research project, TAXONOMY OF DIPTERA under the aegis of the "All India Coordinated project on Insect Taxonomy" funded by the Ministry of Environment \& Forests, Govt. of India under Prof. P.K. Chaudhuri \& Dr. A. Mazumdar implemented in 2002 is in progress. Assistance in the form of material and literature is solicited for its successful execution.

Prof. Xinhua Wang of University of Nankai (China) paid a short visit to our laboratory in 2005. During his visit Prof. P.K. Chaudhuri and I chalked out a plan to prepare a "Directory of chironomids of the Oriental Region" in collaboration with Prof. Wang. The directory awaits publication in Zootaxa soon. The list contains 948 species of 142 genera in 6 subfamilies of chironomids of the Oriental Region, including oriental China and Japan.

Professor Arshad Ali, University of Florida, IFAS, Apopka came to our laboratory to work with us in July, 2006. During his short stay, a program was designed to study the ecology and intraspecific relationship of the species of Glyptotendipes Kieffer. 
Doctoral degree in 2007.

Dr. Uttaran Majumdar

Email: uttaran_majumdar@yahoo.com

Supervisor: Dr. A. Mazumdar, Department of Zoology, University of Burdwan, Burdwan 713 104, India; Email: abhijitau@rediffmail.com

Title of the thesis: "Systematics and biology of the subfamily Chironominae (Diptera: Chironomidae) of eastern India”.

Summary of the Ph.D. thesis:

The thesis contains 77 species of 12 genera in the two tribes Chironomini (10 genera) and Tanytarsini (02 genera). Of the 77 species, Chironomus mayri, Einfeldia arcuta, Glyptotendipes (Phytotendipes) crassispinus, G. (P.). fumilatus, G. (P.) sinusus, Microtendipes semicylis, Paratendipes brevirusticus, Cladotanytarsus dividens, and Parapsectra firmistyla are described as new to science and 33 species reported earlier are revised. The life cycle of 9 species are reared in the field and the laboratory and the immature stages are also described with the relevant illustrations. A brief study of habitats, food and feeding habits, construction of larval residences, silk spinning of the larvae, life cycles, emergence and sex ratios of several species are presented in the thesis. Behaviour of the larvae and pupae of the new species are also included in the thesis.

Adjudicators:

1. Dr. Martin BERG

Associate Professor

Department of Biology

Loyola University of Chicago, $6525 \mathrm{~N}$

Chicago, IL 60626, USA.

2. Dr. J.KALITA

Professor of Zoology

Gauhati University, Guwahati 781014, India.

3. Dr. P.HALDAR

Professor of Zoology

Visva Bharati, Santiniketon, India.

4. Dr. A. Mazumdar (Supervisor)

Department of Zoology

University of Burdwan

Burdwan 713 104, India

M.Phil. thesis:

Ms. Soumi Nandi

Supervisor: Dr. A. Mazumdar, Department of
Zoology, University of Burdwan, Burdwan, 713 104, India.

Title of thesis: "Study of morphology and polytene chromosomes of Glyptotendipes barbipes (Staeger) from India (Diptera: Chironomidae)”.

Summary of the M. Phil thesis:

Morphology of all life stages of Glyptotendipes barbipes (Staeger) is revised using recent terminology and taxonomy. The material used was based on laboratory rearing of larvae. The dissertation also includes descriptions of the polytene chromosomes of the salivary gland of the fourth instar larva of Glyptotendipes barbipes. In general these are noted to possess $2 n=8$ with three metacentric and one acrocentric chromosomes which through comparative studies are reported to vary in different populations.

\section{Chironomus research at University of Pune}

M.Phil. thesis 2003

Mr. Anand A. Babrekar

Supervisor: Dr. B. B. Nath, Department of Zoology, University of Pune, Pune, India.

Title of thesis: "Study of photobehaviour in Chironomus ramosus Chaudhuri et al.”.

Summary of the M. Phil thesis:

The ontogeny of photosensitivity in a holometabolous insect midge Chironomus ramosus was studied. Extracellular electrical activity was recorded from larval and adult photoreceptor organs. We found a progressive increase in photosensitivity, as the development proceeds from larva to adult stage. This is a first report of its kind where developmental profile of photosensitivity in any insect has been described from an ecological context. Chironomid midges have been chosen for this study since developmental stages show ecological transitions. Aquatic bottom dwelling tubicolous larvae metamorphose to a transient pupal stage and subsequently, eclose to terrestrial low-flying adult midges. Unlike larvae, adults were found to be positively phototactic.

We have fabricated special devices and designed novel assays to study photobehavioural responses in different developmental stages. We have also formulated phototactic index (P.I.) for quantitative analysis of photobehaviour. Moreover, the study aimed at finding whether response to intensity and wavelength of light varies in different developmental stages. Interestingly, our study showed a developmental shift in photobehavioural response during 
metamorphosis. Early and late larval instars showed a variable pattern of photoresponse under shorter and longer wavelengths of the visible spectrum and the findings have been correlated to their ecological transitions from pelagic to benthic life style. Similarly, P.I. values shifted from positive to negative and vice-versa throughout the life-cycle of Chironomus. Behavioral data has been corroborated with ERG data (collaborative work with Dr. Gauri Kulkarni, Biophysics Unit, Dept. of Physics, University of Pune). Our electrophysiological data link sensitivity of developmental stage specific photoreceptor organs of larvae and adults to its ecological adaptations.

Chironomus larvae are known to be pests and adults are known for creating a nuisance in human habitats. Adult midges are also medically known for allergic reactions to humans. Therefore, we believe that our findings will help in designing a 'light-trap' as an effective pest control strategy based on developmental stage specific photosensitivity.

Anand A. Babrekar received Prof. V.C.Shah best poster presentation award for the paper entitled "Structural \& functional analysis of photoreceptor cells of Chironomus ramosus" at the XXVII All India Cell Biology Conference \& International Symposium, Jan 7-10, 2004 at Pune, India.

\section{New Chironomidologists in India}

Dr. Niladri HAZRA

Department of Zoology

Balurghat College (North Bengal University)

Balurghat, India.
Area of research: Biodiversity of Chironomids in the riverine system.

Mr. Nirmalaya DAS

Department of Zoology

Kalimpong College (North Bengal University)

Kalimpong, India.

Area of research: Systematics and Biology of Orthocladiid midges of the Himalayas of West Bengal, India.

Dr. T. MIDYA, Professor

Department of Zoology

Presidency College

Calcutta 700073

Area of research: Polytene chromosomes of the Chironomid midges.

\section{Dr. S. CHATTOPADHYAY}

Department of Entomology

Faculty of Forestry

B.A.University, Ranchi, Jharkhand.

Area of research: Biology and Ethology of Chironomids.

\section{Dr. G. K. SAHA}

Department of Zoology

University of Calcutta

34 Ballyganj Circular Road, Calcutta 700019.

Area of research: Behaviour and Limnology of Chironomids

Abhijit Mazumdar, Department of Zoology, University of Burdwan, Burdwan, 713 104, India. abhijitau@rediffmail.com 


\title{
SUBFOSSIL CHIRONOMIDS FROM 18 LAKES IN SOUTHERN AND NORTHERN FINLAND
}

\author{
Tomi P. Luoto
}

\author{
Department of Geology, P.O. Box 64, FIN-00014 University of Helsinki, Finland, \\ E-mail:tomi.luoto@helsinki.fi
}

\section{Introduction}

Midge and especially chironomid (Diptera: Chironomidae) larvae provide an excellent data source of environmental conditions in aquatic ecosystems, particularly in lakes and ponds, where they live abundantly in the bottom of littoral and pelagic zones. Chironomids are a very diverse midge family, for example Paasivirta (2007) lists over 750 species in Finland. Some species are ecologically sensitive, living only in certain types of waters. Their chitinous head capsules preserve in lake sediments as subfossil remains and have been used to interpret past environmental changes in lakes, e.g. changes in temperature, water depth, salinity, productivity, hypolimnetic oxygen and $\mathrm{pH}$ (Walker 2001). Subfossil chironomid analysis has also been used in contemporary ecological studies, as the chironomid assemblage in the topmost sediment layer, if not disturbed, is considered to represent the present chironomid fauna and sampling of the surface sediment is fairly easy and effective. The major disadvantage in subfossil chironomid analysis is the difficulty in identification, because it is often impossible to identify to species or even genus level. However, for example Olander et al. (1999), Larocque et al. (2001) and Nyman et al. (2005) have gathered important information on distribution of chironomids in northern Fennoscandia based on surface sediment samples. Although these studies have led to highly developed chironomid-based palaeotemperature inference models, they are restricted to subarctic regions and do not cover the southern areas of Fennoscandia.
The aim of the present study is to provide data on the distribution of chironomids in southern and northern Finland and to examine whether faunal patterns in distribution exist between these regions. Therefore, 18 lakes in Finland, 11 situated in the southernmost part of the state and 7 in the northernmost part, were studied for their subfossil chironomid fauna. This study presents preliminary results from a wider investigation of chironomid distribution in Finland.

\section{The study area}

The 18 lakes were chosen to represent different lake types in southern $\left(60^{\circ} 13^{\prime}\right.$ to $\left.60^{\circ} 26^{\prime} \mathrm{N}\right)$ and northern Finland (6940’ to 6953' N) (Figure 1). Catchment vegetation of the lakes spans from boreal coniferous forests in the south to tundra vegetation in north. The mean annual air temperature varies between 4.5 (south, HelsinkiVantaa airport) and $-2.0^{\circ} \mathrm{C}$ (north, Kevo research station), and the mean annual precipitation from $649 \mathrm{~mm}$ to $395 \mathrm{~mm}$, respectively. The altitude of the lakes varies from 15 to $404 \mathrm{~m}$ a.s.l. and altitude corrected mean July air temperatures were calculated for individual lakes (Laaksonen 1976) (Table 1). The range in mean July air temperature varies from 16.8 in south to $11.0{ }^{\circ} \mathrm{C}$ in north. All northern lakes were oligotrophic and their surface areas varied from ca. 20 to 90 ha., whereas southern lakes varied more in their trophic status and were generally smaller (Table $1)$. 


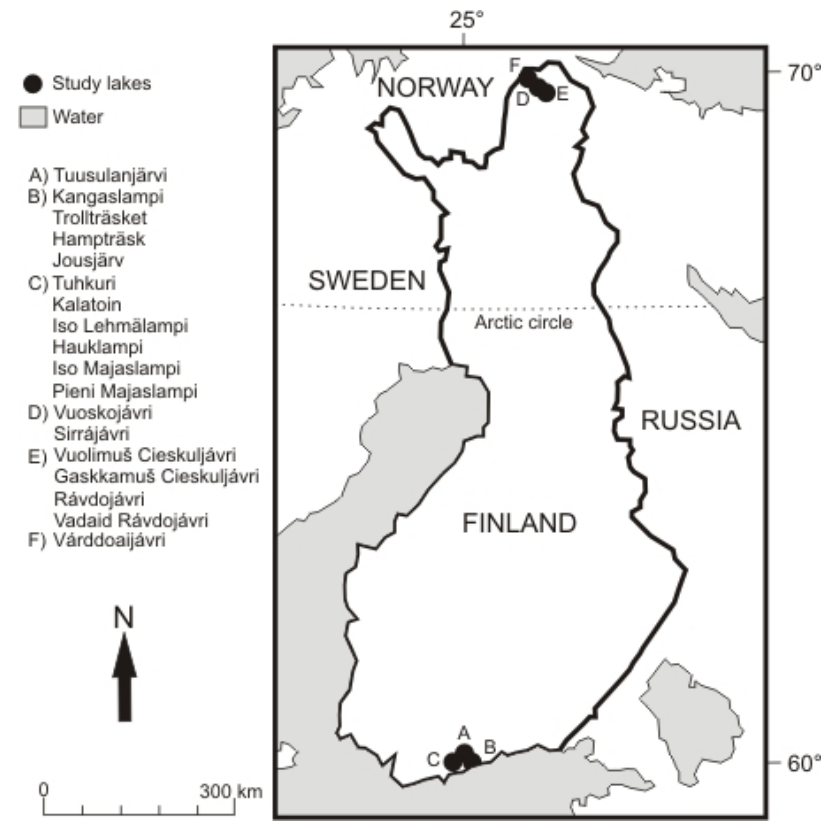

Figure 2. Location of the study sites. Lakes A-C are located in boreal forests, lakes D-E in mountain birch woodland and $\mathrm{F}$ in subarctic tundra.

Table 1. Location, climate and other characteristics of the examined lakes.

\begin{tabular}{lccccccc}
\hline Lake & $\begin{array}{c}\text { Latitude } \\
\left({ }^{\circ}\right)\end{array}$ & $\begin{array}{c}\text { Longitude } \\
\left({ }^{\circ} \mathrm{E}\right)\end{array}$ & $\begin{array}{c}\text { Altitude } \\
(\mathrm{m} \text { a.s.l. })\end{array}$ & $\begin{array}{c}\text { MeanTJul } \\
\left({ }^{\circ} \mathrm{C}\right)\end{array}$ & $\begin{array}{c}\text { Area } \\
(\text { ha) }\end{array}$ & $\begin{array}{c}\text { Trophic } \\
\text { status }\end{array}$ & $\begin{array}{c}\text { Vegetation } \\
\text { zones* }\end{array}$ \\
\hline Varddoaijavri & 69.53 & 26.31 & 404.0 & 11.01 & 28.5 & oligotrophic & Ba \\
Vadaid Ravdojavri & 69.40 & 27.13 & 301.0 & 11.59 & 92.2 & oligotrophic & MBW \\
Gaskkamus Cieskuljavri & 69.43 & 27.07 & 282.6 & 11.70 & 15.0 & oligotrophic & MBW \\
Ravdojavri & 69.40 & 27.12 & 275.8 & 11.74 & 62.3 & oligotrophic & MBW \\
Vuolimus Cieskuljavri & 69.44 & 27.05 & 269.4 & 11.77 & 45.7 & oligotrophic & MBW \\
Sirrajavri & 69.45 & 26.53 & 208.0 & 12.12 & 18.2 & oligotrophic & MBW \\
Vuoskojavri & 69.44 & 26.56 & 145.0 & 12.48 & 19.2 & oligotrophic & MBW \\
Pieni Majaslampi & 60.19 & 24.35 & 97.3 & 16.35 & 1.1 & oligotrophic & SPB \\
Iso Majaslampi & 60.19 & 24.35 & 92.7 & 16.37 & 6.3 & oligotrophic & SPB \\
Iso Lehmälampi & 60.20 & 24.36 & 91.7 & 16.38 & 5.1 & oligotrophic & SPB \\
Kalatoin & 60.20 & 24.37 & 89.5 & 16.39 & 0.9 & dystrophic & SPB \\
Hauklampi & 60.18 & 24.36 & 75.7 & 16.47 & 2.7 & oligotrophic & SPB \\
Tuhkuri & 60.20 & 24.38 & 73.7 & 16.48 & 13.7 & oligotrophic & SPB \\
Jousjärv & 60.20 & 25.11 & 37.3 & 16.69 & 0.5 & dystrophic & SPB \\
Tuusulanjärvi & 60.26 & 25.03 & 37.8 & 16.69 & 600.0 & eutrophic & SPB \\
Trollträsket & 60.20 & 25.09 & 24.0 & 16.77 & 1.3 & mesotophic & SPB \\
Hampträsk & 60.17 & 25.15 & 20.3 & 16.79 & 3.8 & mesotophic & SPB \\
Kangaslampi & 60.13 & 25.08 & 14.6 & 16.82 & 1.4 & eutrophic & SPB \\
\hline
\end{tabular}

* $\mathrm{Ba}=$ barren tundra, MBW = mountain birch woodland, SPB = spruce, pine and birch forest. 


\section{Materials and methods}

The surface sediment samples were obtained with a Limnos gravity corer between February and April in 2005. The sediment samples for subfossil chironomid analysis were prepared using standard methods described in Hofmann (1986) and Walker (2001). A minimum of 100 chironomid head capsules were identified from each sample. The identification was based mainly on Wiederholm (1983). Heiri et al. (2004) was used to identify the Tanytarsini, Sæther $(1975,1976)$ and Walker et al. (1992) for some of the Orthocladiinae and Rieradevall \& Brooks (2001) for the Tanypodinae larvae. The WWW Field Guide to subfossil Midges (Walker 2007) was also very helpful. The nomenclature follows the above mentioned literature.

Detrended correspondence analysis (DCA) was performed using the program CANOCO, version 4.52 (ter Braak 2003) to explore patterns in the distribution of the chironomid taxa in Finland. The DCA was run with detrending by segments, square-root-transformation of species abundances and down weighting of rare species. DCA is an indirect ordination method that summarizes the variation of the species assemblages along the DCA axes.

\section{Results and discussion}

From the sediments of the 18 lakes, a total of 2310 chironomid head capsules were counted and identified to genus or species level. In all, 66 taxa were identified; 40 Chironominae (23 $\begin{array}{llll}\text { Chironomini, } & 16 & \text { Tanytarsini, } & 1\end{array}$ Pseudochironomini), 22 Orthocladiinae, 3 Tanypodinae and 1 Diamesinae. The most common chironomid taxa (Figure 2, Table 2) were Tanytarsus undif. (mean abundance in the lakes $7.8 \%$ ) and Psectrocladius sordidellus type (7.7\%). Ablabesmyia monilis type (6.8\%), Monopsectrocladius calcaratus type (6.4\%) and Procladius (6.3\%) were also common. Monopsectrocladius calcaratus type, Ablabesmyia monilis type, Dicrotendipes pulsus type, Tanytarsus undif. and Procladius occurred in 17 lakes (Table 2) while none of the taxa occurred in all lakes. The most evenly distributed taxa in the lakes, with high effective number of occurrences (Hill's N2), were Ablabesmyia monilis type (13.1), Dicrotendipes pulsus type (11.7) and Psectrocladius sordidellus type (11.0) (Table 2).

Table 2. Chironomid occurrences, Hill's N2 diversity index, maximum and mean percentages and calculated optimum temperatures based on the 18 study lakes.

\begin{tabular}{lccccc}
\hline & Occurrences & Hill's N2 & Maximum & Mean & Opt. temp. $\left({ }^{\circ} \mathrm{C}\right)$ \\
\hline Micropsectra radialis type & 1 & 1.0 & 4.1 & 0.2 & 11.01 \\
Hydrobaenus pilipes type & 2 & 2.0 & 0.7 & 0.1 & 11.37 \\
Heterotrissocladius brundini type & 6 & 3.6 & 10.8 & 1.4 & 11.42 \\
Tanytarsus lugens type & 10 & 7.2 & 10.1 & 2.5 & 11.6 \\
Thienemannimyia & 5 & 4.6 & 1.4 & 0.2 & 11.68 \\
Sergentia coracina type & 7 & 5.9 & 8.4 & 2.0 & 11.69 \\
Zalutschia tatrica type & 4 & 3.0 & 3.5 & 0.4 & 11.75 \\
Heterotrissocladius grimshawi type & 5 & 4.0 & 5.2 & 1.0 & 11.90 \\
Parakiefferiella nigra & 2 & 1.5 & 2.6 & 0.2 & 11.90 \\
Cricotopus pulchripes type & 6 & 4.9 & 4.7 & 1.0 & 11.93 \\
Micropsectra insignilobus type & 9 & 4.2 & 19.8 & 3.2 & 11.97 \\
Protanypus & 1 & 1.0 & 2.6 & 0.1 & 12.12 \\
Corynocera ambigua & 7 & 4.0 & 15.4 & 2.3 & 12.29 \\
Stempellinella & 1 & 1.0 & 0.7 & 0.0 & 12.48 \\
Cricotopus (I.) sp. & 4 & 2.5 & 5.0 & 0.5 & 12.53
\end{tabular}




\begin{tabular}{|c|c|c|c|c|c|}
\hline & Occurrences & Hill's N2 & Maximum & Mean & Opt. temp. $\left({ }^{\circ} \mathrm{C}\right)$ \\
\hline Constempellina brevicosta & 5 & 2.3 & 5.1 & 0.5 & 12.85 \\
\hline Paratanytarsus austriacus type & 2 & 1.4 & 3.6 & 0.2 & 13.14 \\
\hline Paratanytarsus undif. & 14 & 8.7 & 16.2 & 4.1 & 13.25 \\
\hline Micropsectra bidentata type & 7 & 4.0 & 4.3 & 0.5 & 13.52 \\
\hline Monopsectrocladius calcaratus type & 13 & 6.2 & 36.8 & 6.4 & 13.55 \\
\hline Microtendipes pedellus type & 13 & 7.9 & 7.9 & 2.2 & 13.68 \\
\hline Paratanytarsus penicillatus type & 8 & 6.5 & 5.0 & 1.2 & 13.81 \\
\hline Cricotopus (I.) sylvestris type & 15 & 9.6 & 5.8 & 1.4 & 14.06 \\
\hline Pagastiella orophila & 8 & 6.0 & 2.7 & 0.5 & 14.13 \\
\hline Heterotrissocladius marcidus type & 6 & 3.8 & 6.8 & 0.9 & 14.14 \\
\hline Paracladopelma & 2 & 2.0 & 0.9 & 0.1 & 14.31 \\
\hline Cricotopus undif. & 10 & 7.7 & 5.4 & 1.3 & 14.46 \\
\hline Psectrocladius sordidellus type & 17 & 11.0 & 26.0 & 7.7 & 14.71 \\
\hline Cladotanytarsus mancus type & 9 & 4.3 & 11.3 & 1.5 & 14.77 \\
\hline Phaenopsectra flavipes type & 7 & 6.2 & 1.9 & 0.5 & 14.87 \\
\hline Zalutschia zalutschicola & 10 & 7.9 & 6.0 & 1.9 & 14.87 \\
\hline Ablabesmyia monilis type & 17 & 13.1 & 15.6 & 6.8 & 14.95 \\
\hline Dicrotendipes pulsus type & 17 & 11.7 & 12.1 & 3.9 & 14.96 \\
\hline Heterotanytarsus apicalis type & 6 & 3.7 & 9.9 & 1.6 & 15.22 \\
\hline Psectrocladius (Mesopsectrocladius) & 4 & 2.9 & 2.6 & 0.3 & 15.27 \\
\hline Cryptochironomus & 2 & 1.8 & 1.6 & 0.1 & 15.37 \\
\hline Polypedilum nubeculosum type & 12 & 9.5 & 3.1 & 1.0 & 15.63 \\
\hline Tanytarsus undif. & 17 & 7.4 & 41.9 & 7.8 & 15.64 \\
\hline Procladius & 17 & 6.4 & 38.6 & 6.3 & 15.67 \\
\hline Psectrocladius (Allopsectrocladius) & 12 & 4.3 & 25.0 & 3.5 & 15.74 \\
\hline Cladopelma viridulum type & 13 & 6.5 & 7.7 & 1.3 & 15.91 \\
\hline Pseudochironomus prasinatus type & 5 & 4.2 & 2.9 & 0.5 & 16.06 \\
\hline Tanytarsus pallidicornis type & 13 & 7.3 & 12.4 & 3.0 & 16.07 \\
\hline Tanytarsus chinyensis type & 6 & 2.7 & 7.3 & 0.7 & 16.31 \\
\hline Chironomus anthracinus type & 11 & 6.5 & 13.6 & 2.9 & 16.31 \\
\hline Limnophyes & 6 & 3.6 & 8.7 & 1.3 & 16.34 \\
\hline Paratendipes albimanus type & 1 & 1.0 & 5.8 & 0.3 & 16.39 \\
\hline Corynoneura lobata type & 5 & 1.6 & 29.7 & 2.1 & 16.39 \\
\hline Chironomus plumosus type & 11 & 3.9 & 19.7 & 2.5 & 16.41 \\
\hline Lauterborniella agrayloides type & 5 & 4.6 & 2.3 & 0.4 & 16.54 \\
\hline Corynoneura scutellata type & 5 & 3.0 & 5.8 & 0.6 & 16.56 \\
\hline Nanocladius (N.) rectinervis type & 4 & 3.0 & 3.0 & 0.4 & 16.56 \\
\hline
\end{tabular}




\begin{tabular}{lccccc}
\hline & Occurrences & Hill's N2 & Maximum & Mean & Opt. temp. $\left({ }^{\circ} \mathrm{C}\right)$ \\
\hline Tanytarsus mendax type & 7 & 6.4 & 6.8 & 1.8 & 16.57 \\
Microchironomus tener type & 1 & 1.0 & 11.0 & 0.6 & 16.69 \\
Endochironomus impar type & 2 & 1.9 & 1.6 & 0.1 & 16.69 \\
Endochironomus albipennis type & 3 & 2.4 & 3.4 & 0.4 & 16.74 \\
Orthocladius sp. & 3 & 2.7 & 4.0 & 0.5 & 16.75 \\
Einfeldia pagana type & 3 & 2.5 & 6.8 & 0.7 & 16.75 \\
Rheotanytarsus & 5 & 3.6 & 4.3 & 0.6 & 16.76 \\
Polypedilum sordens type & 3 & 1.9 & 3.4 & 0.3 & 16.76 \\
Mesocricotopus thienemannii & 1 & 1.0 & 1.5 & 0.1 & 16.79 \\
Glyptotendipes pallens type & 4 & 2.3 & 10.3 & 0.9 & 16.79 \\
Omisus caledonicus & 1 & 1.0 & 0.9 & 0.0 & 16.82 \\
Parachironomus varus type & 1 & 1.0 & 3.4 & 0.2 & 16.82 \\
Endochironomus tendens type & 1 & 1.0 & 0.9 & 0.0 & 16.82 \\
Kiefferulus tendipediformis type & 1 & 1.0 & 1.7 & 0.1 & 16.82 \\
\hline
\end{tabular}

Several chironomid taxa occurred mainly in the northern lakes, whereas many were found only from southern sites (Figure 2). Some taxa, e.g. Psectrocladius sordidellus type and Ablabesmyia monilis type were found abundantly in both northern and southern lakes (Figure 2). Micropsectra radialis type occurred only in Várddoaijávri (Figure 2, Table 2), which is the coldest of the lakes, located in the subarctic tundra of the northernmost Finland. Also Heterotrissocladius brundini type and Paratanytarsus undif., were at their highest abundance in Várddoaijávri. Paratanytarsus undif. occurred also in all mountain birch woodland lakes and in some boreal forest lakes. A clear northern distribution with preference to mountain birch woodland lakes (Table 1), was observed for Tanytarsus lugens type, Thienemannimyia, Sergentia coracina type, Zalutschia tatrica type, Heterotrissocladius grimshawi type, Parakiefferiella nigra, Cricotopus pulchripes type, Micropsectra insignilobus type, Protanypus, Corynocera ambigua, Cricotopus (I.) sp., Constempellina brevicosta and Paratanytarsus austriacus type. A southern distribution was observed for many taxa (Figure 2). Polypedilum sordens type, Rheotanytarsus, Orthocladius sp., Endochironomus impar type, Tanytarsus mendax type, Nanocladius (N.) rectinervis type, Corynoneura scutellata type, Lauterborniella agrayloides type, Corynoneura lobata type, Paratendipes albimanus type, Limnophyes, Tanytarsus chinyensis type, T. pallidicornis type, Pseudochironomus prasinatus type, Cladopelma viridulum type and Psectrocladius (Allopsectrocladius) occurred mainly in southern lakes, which are situated in the boreal forest vegetation zone. Glyptotendipes pallens type, Einfeldia pagana type, Endochironomus albipennis type, Microchironomus tener type and Chironomus plumosus type also had southern occurrences, and they showed further preference for nutrient rich lakes (Figure 2, Table 1). Also Chironomus anthracinus type and Procladius had their maximum abundances in southern, nutrientrich lakes. The general results of the distribution of chironomids in the present study seem to agree with other studies (e.g. Brodersen and Quinlan 2006; Brooks 2006). 

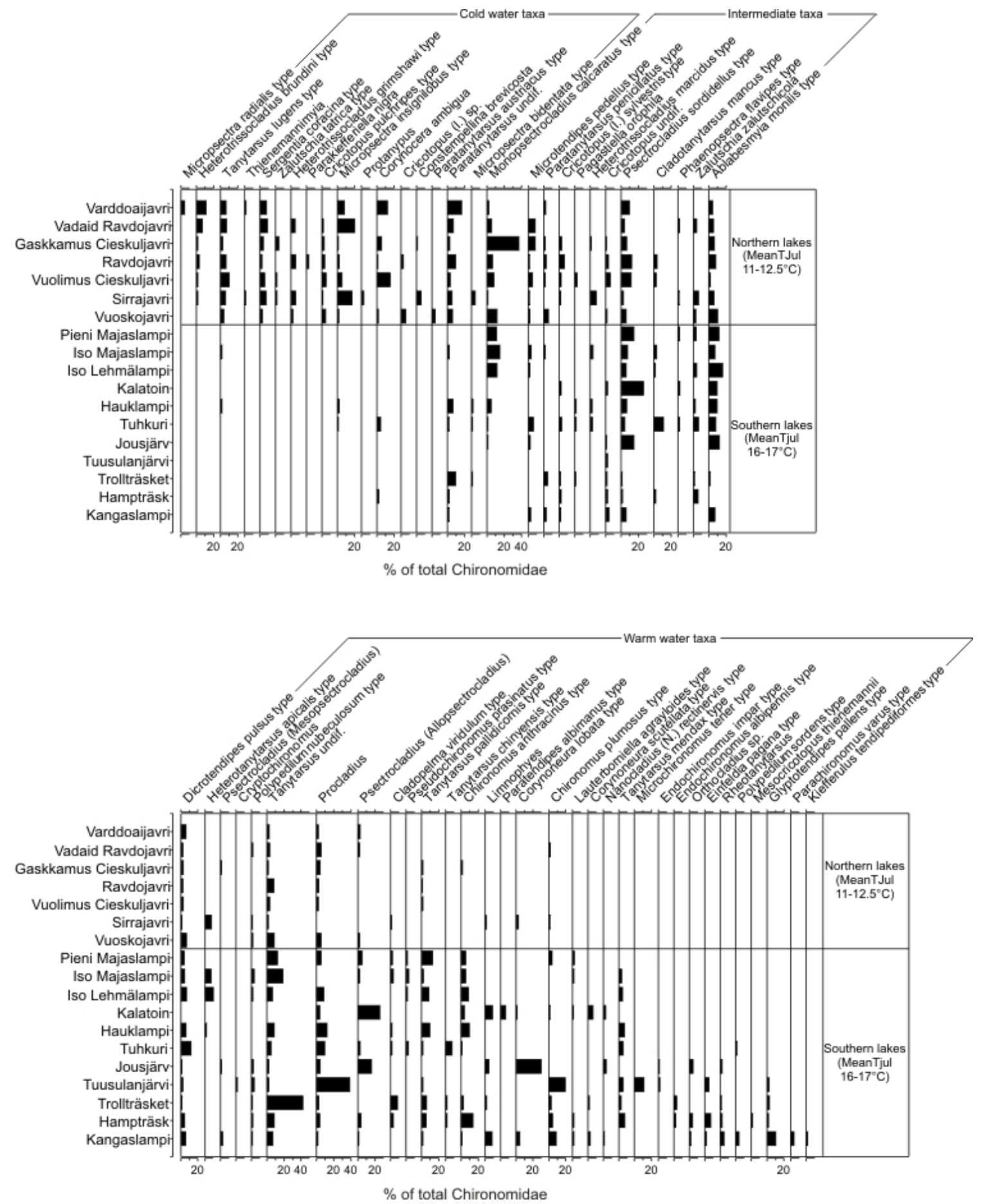

Figure 3. Distribution of the most common Chironomidae. The taxa are ordered based on their optimum temperatures from the coldest (left) to the warmest (right) and the lakes are ordered based on their mean July air temperatures from the coldest (top) to the warmest (bottom).

The DCA ordination diagram (Figure 3) indicates that the samples (i.e. lakes) are clearly clustered into several groups according to their chironomid fauna. The scores for the southern and northern lakes are distinctly different from each other; the southern lakes having low or intermediate values for DCA axis 1 and northern lakes having high values. The northern lakes had very similar scores along both DCA axes suggesting that their chironomid assemblages were very similar. There was also clustering among the southern lakes. The meso-eutrophic southern lakes had rather low 
values along both DCA axis and the most eutrophic lake (Tuusulanjärvi) had distinctly low values for both axes. The dystrophic, macrophyterich lakes had highest scores for the DCA axis 2 values and low axis 1 values and the oligotrophic southern lakes had scores in the center of the ordination diagram.

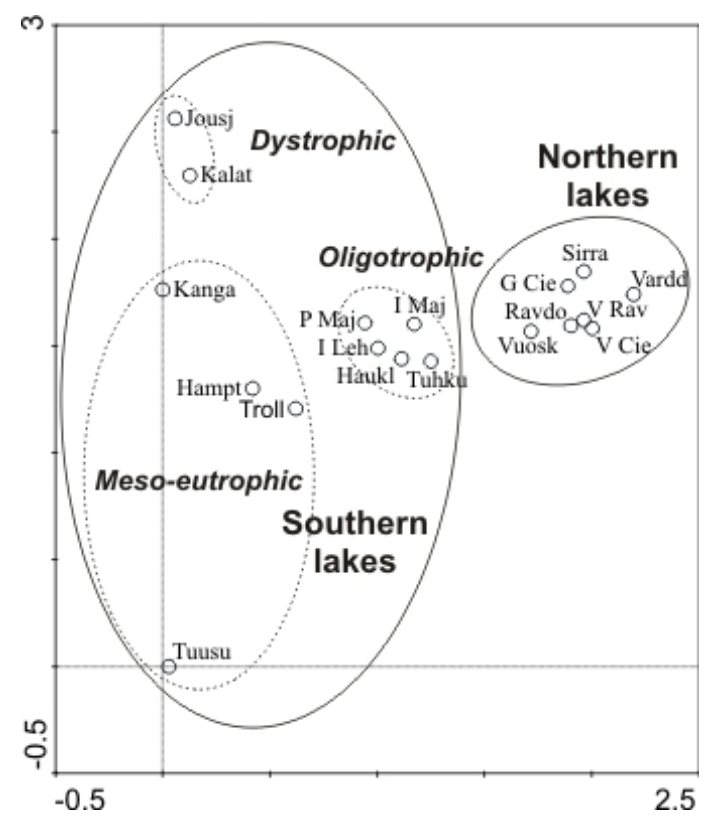

Figure 4. Figure 3. DCA plot for samples based on the chironomid assemblages in the 18 lakes.

According to the current results, it appears that the occurrences of some chironomid taxa are restricted to either southern or northern lakes and some were found in both regions (Figure 2). This suggests that faunal patterns exist in distribution of chironomids in Finland. It is possible that climatic factors are behind this geographical distribution of chironomids, since climate differs considerably between southern and northern Finland (Table 1) and temperature is known to affect the occurrence of chironomids (Brooks 2006). Because such differences in distribution were found, optimum temperatures, based on lake specific July air temperatures (meanTJul) were calculated for each taxon (Table 2) and the chironomids were grouped to cold, intermediate and warm water inhabitants (Figure 2). However, it is likely that many other chemical, physical or ecological factors besides climate affect their distribution and are influencing these faunal patterns. For example the northern lakes in the present study were much larger than the southern ones and this may be one contributing factor causing the differences in northern and southern chironomid assemblages. Olander et al. (1999) found the organic content of the sediment (measured as loss on ignition: LOI) and lake water temperature to be the key factors and Nyman et al. (2005) showed that LOI, total organic carbon (TOC), $\mathrm{pH}$ and lake specific July air temperature were the most significant factors affecting chironomid distributions in western Finnish Lapland. Larocque et al. (2001) concluded that mean July air temperature, LOI and maximum lake depth were the most important environmental variables in subarctic northern Sweden. The present study provided data only on chironomids in southern and northern lakes and therefore presents no information on distribution in the geographical region in between. For more detailed information on distribution patterns of chironomids more research is needed from a wider spatial range.

\section{Conclusions}

The southern lakes were generally dissimilar in their chironomid assemblages compared to northern lakes, and furthermore showed some clear faunal patterns. Chironomid assemblages were similar within the 5 oligotrophic lakes, 2 dystrophic lakes and 4 meso-eutrophic lakes (Figure 3). It is probable that the limnological diversity in lake ecosystems in southern Finland, e.g. variation in the trophic status, water color and macrophyte-cover, provided suitable habitats for different chironomid taxa, resulting in different faunal assemblages in certain types of lakes and that similar conditions does not exist in northern Finland.

\section{Acknowledgements}

This study was funded by the Finnish Entomological Society, the Nordenskiöld Foundation, the Walter and Lisi Wahl's fund, the Finnish Graduate School in Geology and the Ephippium project (The Academy of Finland, grant no. 1107062). Liisa Nevalainen, Seija Kultti, Susanna Kihlman and the Kevo research station staff are appreciated for the assistance with the field work. Liisa Nevalainen is also thanked for her comments on the manuscript and Kati Ojanen for her remarks on the text. Valuable comments of an anonymous reviewer are acknowledged. 


\section{References}

Brodersen, K. P. and Quinlan, R. 2006. Midges as palaeoindicators of lake productivity, eutrophication and hypolimnetic oxygen. Quatern. Sci. Rev. 25: 1995-2012.

Brooks, S. J. 2006. Fossil midges (Diptera chironomidae) as palaeoclimatic indicators for the Eurasian region. Quatern. Sci. Rev. 25: 1894-1910.

Heiri, O., Ekrem, T. and Willassen, E. 2004. Larval head capsules of European Micropsectra, Paratanytarsus and Tanytarsus (Diptera: Chironomidae: Tanytarsini). (http://www.bio.uu.nl/ palaeo/Chironomids/T anytarsini/intro.htm).

Hofmann, W. 1986. Chironomid analysis. In: Berglund B.E. (eds) Handbook of Holocene Palaeoecology and Palaeohydrology. John Wiley \& Sons, New York, pp 715-727.

Laaksonen, K. 1976. The dependence of mean air temperatures upon latitude and altitude in Fennoscandia (1921-1950). - Ann. Acad. Sci. Fenn. 119A: 5-19.

Larocque, I., Hall, R. I. and Grahn, E. 2001. Chironomids as indicators of climate change: a 100-lake training set from a subarctic region of northern Sweden (Lapland). - $J$. Paleolimnol. 26: 307-322.

Nyman, M., Korhola, A. and Brooks, S. J. 2005. The distribution and diversity of Chironomidae (Insecta: Diptera) in western Finnish Lapland, with special emphasis on shallow lakes. - Global Ecol. Biogeogr. 14: 137-153.

Olander, H., Birks, H. J. B., Korhola, A. and Blom, T. 1999. An expanded calibration model for inferring lakewater and air temperatures from fossil chironomid assemblages in northern Fennoscandia. The Holocene 9: 279-294.
Paasivirta, L. 2007. Chironomidae (Diptera: Nematocera) in the biogeographical provinces of Finland.

(http://www.saunalahti.fi/jailmon/FinnishChir onomidae.htm).

Rieradevall, M. and Brooks, S. J. 2001. An identification guide to subfossil Tanypodinae larvae (Insecta: Diptera: Chironomidae) based on cephalic setation. - J. Paleolimnol. 25: 8199.

Sæther, O. A. 1975. Nearctic and Palearctic Heterotrissocladius (Diptera: Chironomidae). - Bull. Fish. Res. Bd Can. 193: 1-67.

Sæther, O. A. 1976. Revision of Hydrobaenus, Trissocladius, Zalutschia, Paratrissocladius, and some related genera (Diptera: Chironomidae). - Bull. Fish. Res. Bd Can. 195: 1-287.

ter Braak, C. J. F. 2003. Program CANOCO, Version 4.52. Biometris - quantitative methods in the life and earth sciences. Plant Research International, Wageningen University and Research Centre, Wageningen, The Netherlands.

Walker, I. R., Oliver, D. R. and Dillon, M. E. 1992. The larva and habitat of Parakiefferiella nigra Brundin (Diptera: Chironomidae). Netherlands Journal of Aquatic Ecology 26: 527-531.

Walker, I. R. 2001. Midges: Chironomidae and related Diptera. In: Smol, J. P., Birks, H. J. B. and Last WM (eds) Tracking Environmental Change Using Lake Sediments. Volume 4: Zoological Indicators. Kluwer Academic Publishers, Dordrecht, The Netherlands, pp 43-66.

Walker, I. R. 2007. The WWW Field Guide to Fossil Midges.

(http://www.paleolab.ca/wwwguide/).

Wiederholm, T. (ed.) 1983. Chironomidae of the Holarctic region. Keys and diagnoses. Part 1 Larvae. - sEnt. Scand. Suppl. 19, 457 pp. 


\title{
CHIRONOMID COMMUNITIES IN THE LITTORAL ZONE ON THE WESTERN COAST OF THE SOUTHERN BAIKAL BASIN (STRUCTURE, DISTRIBUTION, SEASONAL DYNAMICS)
}

\author{
Lyubov Kravtsova \\ Limnological Institute SD RAS, Ulan-Batorskaya, 3, Irkutsk, 664033, Russia \\ E-mail: lk@lin.irk.ru
}

\begin{abstract}
The spatial distribution of chironomid communities in the littoral zone $(0-20 \mathrm{~m})$ of the western coast of the southern Baikal basin is investigated. The fauna is composed of 16 species and forms of chironomid larvae, comprising 10 communities. It has been found that the communities are characterized by rather poor species diversity; Shannon's index varies from 0.7 to 2.1 bit. Their distribution is affected by hydro-lithodynamic conditions, type of bottom sediments and macrophyte development. The peak of maximal biomass of chironomid larvae on the facies of non-rounded rock debris near Berezovy Cape is recorded in spring.
\end{abstract}

\section{Introduction}

The fauna of Baikalian Chironomidae is diverse; according to our and references data (Linevich 1981, Kozhova et al., 2000, etc.), it includes 166 species and forms of Chironomidae larvae from 5 subfamilies Tanypodinae (11), Prodiamesinae (2), Diamesinae (10), Orthocladiinae (59), Chironominae (84). The species diversity of Chironomidae larvae effects the structure of their communities. At present, Chironomidae distribution and diversity at different Baikalian biotops is known. In open Baikal, chironomid larvae are most abundant and rich in species on rocky ground at 0 to $5 \mathrm{~m}$ depth (Shapovalova 1969, Samburova 1982, Kravtsova 2005). In deeper water (more $20 \mathrm{~m}$ ) they are few in species and only occasionally encountered (Linevich 1981, Kozhova and Kravtsova 1998). The structure of Chironomidae communities found out on the base of species domination principle by biomass is poorly studied. The number of publications on Baikal chironomid communities and their structural peculiarities is extremely limited (Kravtsova and Yerbayeva 1990, Kravtsova 1991, Kravtsova et al. 1999). Chironomidae play a considerable role in water bodies functioning (Lang 2000, Crozet et al.
2001, Scrimgeour et al. 2001, Verneaux and Verneaux, 2002, Brodersen and Anderson 2002, etc.), but papers concerning $\alpha$-diversity of Chironomidae communities are either not numerous (Pastukhova 1983). Studies of structural organization of communities of Chironomidae plays an important role from the point of view of interspecies interactions, especially in population of water bodies bottom with a complex geological and geomorphological structure, in particular, on Lake Baikal. This work focuses on the structure of chironomid communities, their distribution and seasonal dynamics in the littoral zone of the western coast of the Southern Baikal basin.

\section{Materials and Methods}

Research material for this study consisted of 67 quantitative benthos samples with Chironomidae collected in Bolshye Koty Bay, 18 km northeast of the Angara River outflow of the lake, in September 1988. Division into bottom underwater complexes (BUCs): beach (B), shallow water terrace (SWT), underwater slope (US) and underwater canyon (UC) was based on physicalgeographical and geomorphological characteristics of the bottom. Subdivision into facies was according to predominant type of bottom deposits. The samples were collected at 0 $20 \mathrm{~m}$ depth along transects perpendicular to the shoreline. The benthos was sampled by divers using $0.09 \mathrm{~m}^{2}$ frames, repeated three times. Boulders were placed in bags and lifted on board where animals and plants were picked or washed off into a basin.

Seasonal dynamics of the chironomid communities were studied from 155 quantitative benthos samples, collected near Berezovy Cape. From August 2000 until August 2001, samples were taken from a $0.1 \mathrm{~m}^{2}$ count frame 5-10 times by divers at site $\mathrm{N} 1$ (3 m depth, facies on nonrounded rock debris, total bottom area under study $60 \mathrm{~m}^{2}$ ). All samples were filtered through 
sieves of mill-gauze № 35 and fixed with $4 \%$ formalin.

'Communities' were defined as populations of different species co-existing in space and time (Begon et al. 1996). The "dominance approach" to the definition was used (Vorobjov 1949). Subdominant species of each community were diagnosed using the density index $\sqrt{ } \mathrm{PB}$ (Brotskaya and Zenkevich 1939), modified by Konstantinov (1986): where $\mathrm{P}$ is the frequency of a given species in samples belonging to the community (in \%), and $\mathrm{B}$ is percentage of a species biomass in the total biomass of the community. Communities were designated by their dominant species, which usually had the highest density index. Species with density index values higher then ten percent were treated as sub-dominant, and species with less than $10 \%$ called secondary. When only a single sample was dominated by a set of species, this sample was designated a "coenotic assemblage". This was typical when sampling took place at the edge of a community. Coenotic assemblages represented by one sample were not examined further, because it is not known if dominance in these cases was due to random fluctuation or not. The community structure characterization was based on: Shannon's species diversity index $-H=-\sum n_{i} / N$ $\log _{2}\left(n_{i} / N\right)$; Simpson dominance index $-c=$ $\Sigma\left(n_{i} / N\right)^{2}$; equitability by Pielou - $e=H / \log S$, where $n_{i}$ is the estimate of importance (biomass, $\mathrm{mg} \mathrm{m}^{-2}$ ) of each of species in the community, $N$ is the sum of $n_{i}, S$ is species number (Odum 1971).

\section{Results}

Sixteen species and forms of chironomid larvae comprising 10 communities were recorded (Table $1,2)$. Chironomid communities are rather poor in species number varying from 3 to 13 , the fraction of dominating species makes from $40 \%$ to $87 \%$ of total biomass. Shannon's index varies from 0.7 to 2.1 bit. In Bol'shiye Koty Bay, the communities of Chironomidae studied occur on facies of gravel, pebble, brick, boulders, non-grained rock debris, silt, mixed silt and pure sand, and near Berezovy Cape - on the facies of non-rounded rock debris. On biotops relatively homogenous by bottom sediments composition, species number in the major part of communities is not great, and Shannon's index, respectively, is not high (see Table 2). In widely distributed Chironomidae communities (Bol'shiye Koty Bay), the concentration of domination of one species is high, and the equitability is low, whereas in spatially localized communities (Berezovy Cape), the concentration of domination of one species is low, and the equitability is high. As a rule, locally distributed communities are formed by species with similar requirements to the environment, and their contribution in total biomass is approximately equal.

Table 1. Characteristics of chironomid communities in Bolshye Koty Bay, Southern Baikal (September, 1988)

\begin{tabular}{llllllll}
\hline Communities & $\begin{array}{l}\text { Number } \\
\text { of taxa }\end{array}$ & $\begin{array}{l}\mathrm{B} \pm \mathrm{m}, \\
\mathrm{mg} \mathrm{m}^{-2}\end{array}$ & $\begin{array}{l}\mathrm{H}, \\
\text { bit }\end{array}$ & $\mathrm{C}$ & $\mathrm{e}$ & $\mathrm{n}$ \\
\hline Orthocladius gr. thienemanni & 6 & $28 \pm 9$ & 52 & 1.9 & 0.35 & 0.72 & 4 \\
Orthocladius gr. olivaceus & 4 & $10 \pm 5$ & 68 & 1.4 & 0.50 & 0.70 & 5 \\
Orthocladius frigidus & 6 & $12 \pm 11$ & 40 & 2.1 & 0.27 & 0.82 & 3 \\
Cricotopus bicinctus & 6 & $183 \pm 176$ & 84 & 0.9 & 0.71 & 0.37 & 2 \\
Paratanytarsus baicalensis & 6 & $13 \pm 3$ & 82 & 1.1 & 0.67 & 0.42 & 11 \\
Sergentia baicalensis & 13 & $93 \pm 22$ & 87 & 0.9 & 0.76 & 0.24 & 28 \\
Sergentia nebulosa & 3 & $68 \pm 41$ & 83 & 0.7 & 0.72 & 0.44 & 2 \\
Sergentia sp. & 5 & $130 \pm 56$ & 85 & 0.8 & 0.74 & 0.33 & 5 \\
\hline
\end{tabular}

Note. $\mathrm{B}+\mathrm{m}$ - mean community biomass; $\mathrm{m}$ - mistake of averages; \% - part of dominant species in total community biomass; parameters: $\mathrm{H}$ - Shannon's species diversity, $\mathrm{C}$ - dominance by Simpson, e equitability by Pielou; $\mathrm{n}$ - number of samples. 
Table 2. Characteristics of three chironomid communities at the experimental site near Berezovy Cape (Southern Baikal, 2000-2001)

\begin{tabular}{|c|c|c|c|c|c|c|c|c|c|c|c|c|c|c|}
\hline \multirow[t]{3}{*}{ Date } & \multicolumn{14}{|c|}{ Communities } \\
\hline & \multicolumn{7}{|c|}{ Orthocladius nitidoscutellatus } & \multicolumn{7}{|c|}{ Paratanytarsus baicalensis } \\
\hline & $\mathrm{N}$ & $\begin{array}{l}\mathrm{B} \pm \mathrm{m}, \\
\mathrm{mg} \mathrm{m}^{-2}\end{array}$ & $\%$ & $\begin{array}{c}\mathrm{H}, \\
\text { bit }\end{array}$ & $\mathrm{C}$ & $\mathrm{e}$ & $\mathrm{n}$ & $\mathrm{N}$ & $\begin{array}{l}\mathrm{B} \pm \mathrm{m}, \\
\mathrm{mg} \mathrm{m}^{-2}\end{array}$ & $\%$ & $\begin{array}{r}\mathrm{H}, \\
\text { bit }\end{array}$ & $\mathrm{C}$ & $\mathrm{e}$ & $\mathrm{n}$ \\
\hline 29.08 .00 & 7 & $6.7 \pm 2.0$ & 60 & 1.2 & 0.48 & 0.61 & 5 & - & - & & - & - & - & - \\
\hline 19.09 .00 & & - & & - & - & - & - & 3 & $13.4 \pm 4.9$ & 46 & 1.1 & 0.67 & 0.97 & 2 \\
\hline 02.11 .00 & 3 & $1.1 \pm 0.3$ & 61 & 0.8 & 0.46 & 0.77 & 9 & 2 & $3.8 \pm 2.3$ & 67 & 0.7 & 0.51 & 0.95 & 2 \\
\hline 21.12 .00 & & - & & - & - & - & - & 4 & $5.4 \pm 1.6$ & 57 & 1.0 & 0.65 & 0.73 & 4 \\
\hline 29.01.01 & 4 & $36.3 \pm 16.9$ & 54 & 1.0 & 0.62 & 0.73 & 4 & 4 & $18.4 \pm 4.1$ & 44 & 1.1 & 0.62 & 0.77 & 6 \\
\hline 27.02 .01 & 3 & $94.5 \pm 20.1$ & 73 & 0.7 & 0.43 & 0.70 & 6 & - & - & & - & - & - & - \\
\hline 27.03.01 & 4 & $153.7 \pm 31.8$ & 68 & 0.8 & 0.47 & 0.60 & 9 & - & - & & - & - & - & - \\
\hline 10.04 .01 & 3 & $23.5 \pm 4.8$ & 60 & 0.9 & 0.54 & 0.85 & 8 & - & - & & - & - & - & - \\
\hline 31.05 .01 & 4 & $609.1 \pm 148.2$ & 69 & 0.8 & 0.44 & 0.56 & 10 & - & - & & - & - & - & - \\
\hline 03.07.01 & 4 & $27.4 \pm 1.9$ & 55 & 1.0 & 0.60 & 0.71 & 4 & 4 & $47.7 \pm 14$ & 61 & 0.9 & 0.52 & 0.64 & 6 \\
\hline 30.07 .01 & 4 & $29.4 \pm 7.3$ & 72 & 0.9 & 0.43 & 0.62 & 4 & 3 & $11.8 \pm 3.8$ & 74 & 0.8 & 0.52 & 0.70 & 2 \\
\hline 27.08 .01 & 3 & $3.7 \pm 0.6$ & 74 & 0.8 & 0.51 & 0.68 & 8 & & - & & - & - & - & - \\
\hline
\end{tabular}

Table 2 continued

\begin{tabular}{llllllll}
\hline Date & \multicolumn{7}{l}{ Communities } \\
\cline { 2 - 8 } & \multicolumn{7}{l}{ Orthocladius sp. } \\
\cline { 2 - 8 } $\mathrm{mg} \mathrm{m}^{-2}$ & $\%$ & H, bit & $\mathrm{C}$ & $\mathrm{e}$ & $\mathrm{n}$ \\
\hline 29.08 .00 & - & - & - & - & - & - \\
19.09 .00 & 5 & $12.6 \pm 2.5$ & 61 & 0.9 & 0.56 & 0.58 & 5 \\
02.11 .00 & - & - & & - & - & - & - \\
21.12 .00 & 3 & $5.4 \pm 1.4$ & 67 & 0.9 & 0.59 & 0.79 & 2 \\
29.01 .01 & - & - & & - & - & - & - \\
27.02 .01 & - & - & & - & - & - & - \\
27.03 .01 & - & - & & - & - & - & - \\
10.04 .01 & - & - & & - & - & - & - \\
31.05 .01 & - & - & & - & - & - & - \\
03.07 .01 & - & - & & - & - & - & - \\
30.07 .01 & 4 & $15.5 \pm 5.2$ & 54 & 1.2 & 0.61 & 0.85 & 3 \\
27.08 .01 & & - & & - & - & - & - \\
\hline
\end{tabular}

Note. $\mathrm{N}$ - number of taxa in community; $\mathrm{B}+\mathrm{m}$ - mean community biomass; $\mathrm{m}$ - mistake of averages; \% part of dominant species in total community biomass; parameters: $\mathrm{H}$ - Shannon's species diversity, C dominance by Simpson, e - equitability by Pielou; $n$ - number of samples.

Seasonal dynamics of chironomid larvae biomass near Berezovy Cape is shown in Figure 1. Maximal Chironomidae larvae biomass is registered in spring, and minimal one - in autumn. In spring, large elder (age groups III- IV) larvae dominate in Lake Baikal. By autumn, imago of major part of species fly out, and Chironomidae populations become rarefied. At that time, small younger larvae (age groups I and II) of new generations widely occur.

\section{Discussion}

The structure of the communities in some taxocenes, chironomids in particular, differs from that of zoobenthos as a whole.

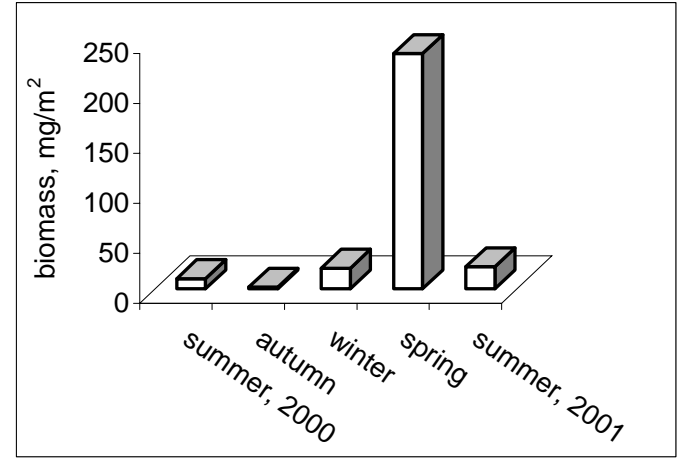

Figure 1. Seasonal dynamics of chironomid larvae biomass near Berezovy Cape (Southern Baikal, 2000-2001) 
The species diversity of chironomid communities, assessed according to Shannon's index is much lower, but it exhibits higher dominance concentration indices, according to Simpson, and equitability, according to Pielou, compared to macroinvertebrate communities (Kravtsova et al. 2004). Despite this, the spatial distribution of chironomid communities is governed by the same regularities as the zoobenthos.

Spatial fauna and flora distribution is determined by the character of bottom sediments formed under different sedimentation conditions. The inhabitants of the bottom at 0-1.5 m depth (BUC B) are rather scanty due to intense hydrodynamic activity and wave breaking, where the rates of near-bottom flows reach $5 \mathrm{~m} / \mathrm{s}$ sometimes (Karabanov and Kulishenko 1990). We can see algal associations Didymosphenia geminata, Tetrasporopsis sp.+ D. geminata with chironomid communities Orthocladius gr. thienemanni, O. gr. olivaceus.

Below $1.5 \mathrm{~m}$, according to hydro- and lithodynamical situations there appear to be two zones different in vegetation composition and community diversity. In the first zone, the bottom consists of coarse-grained material (gravel, pebble, brick, boulders, non-grained rock debris); near-bottom currents are strong and waves break there. There are associations of algae $D$. geminata, Tetrasporopsis sp. + D. geminata, Draparnaldioides baicalensis, D. pumila. All the chironomidae communities (Table 1) are found in this area. Nearer to the external edge of SWT (to the bend line in US at 4-5 $\mathrm{m}$ depth) algal associations characteristic of the second zone appear.

In the second zone (depth 8-20 m), bottom sediments are fine-grained (silt, mixed silt and pure sand). Lithodynamics are determined by decrease in strength of hydrodynamical processes and increase in gravitation ones, by sediment transit and accumulation (BUCs US, UC). The velocities of near-bottom currents are less than $0.6 \mathrm{sm} / \mathrm{s}$ (Slugina et al. 1995). The algal association Cladophora compacta, C. floccosa, C. kursanovi, Myriophyllum spicatum, Fontinalis sp. and Stratonostoc verrucosum is widespread. Draparnaldioides associations are absent. Communities of Chironomidae Sergentia sp., S. baicalensis, S. nebulosa, Paratanytarsus baicalensis inhabit this zone.

In general, the distribution of chironomid communities at the site studied is patchy. Belt distribution is observed in communities dominated by chironomids of the genus Orthocladius (BUCs B, SWT). Analogous regularities are observed in the shallow zone on the eastern side of southern Lake Baikal. Associations occur of the algae Ulothrix zonata, Tetraspora cylindrica var. bullosa, D. pilosa, as well as chironomid communities indicated in Table 1. They are characterized by similar structure. Thus, morphological heterogeneity of bottom, and variability of environmental factors determine the "mosaic" distribution of macroinvertebrates communities in the shallows of Lake Baikal. This is also typical in shallow marine ecosystems (Kusakin et al. 1974).

Chironomid larval biomass varies with the biology of species forming the communities. It seems most likely that the flight time of the species is different.

We found that a fairly small area of bottom near Berezovy Cape is inhabited by three chironomid larval communities existing on relatively homogeneous bottom sediments: Orthocladius nitidoscutellatus, Orthocladius sp., Paratanytarsus baicalensis. An O. nitidoscutellatus community becomes abundant in spring but by autumn its biomass is reduced by one order, while the occurrence of the communities with $P$. baicalensis and Orthocladius sp. grows. All communities considered have characteristics similar to the chironomid communities inhabiting Bolshye Koty Bay, and also the waters near the east coast of the southern Baikal basin in the region of UtulikKhara-Murin Rivers (Kravtsova 1991).

\section{Conclusions}

Spatial distribution of chironomid communities depends upon hydro-lithodynamic conditions of their habitat, type of bottom sediments and macrophyte development. The community structure of the chironomids is significantly simpler than in Baikal zoobenthic communities in general. Communities are characterized by higher indices of Simpson dominance and Pielou equitability. Seasonal dynamics of chironomid larvae biomass are defined by the life cycles of the species.

\section{Acknowledgements}

The author is deeply grateful to the Head of the Laboratory of Aquatic organisms LIN SB RAS, Dr. O.A.Timoshkin for the organization of regular surveying of the benthos biocenoses at the experimental site near Berezovy Cape. Thanks are also offered to the divers I. Khanaev, I. Parfeevets, A. Kupchinsky, K. Ivanov, V. 
Votyakov and post-graduate student A. Blokhina for their assistance in sampling, and also to all researchers participating in the expeditions. Special thanks are addressed to M.A.Makarchenko for identifying chironomid pupae and imagos. An early version of this manuscript was reviewed by G.W.Coulter and the author is grateful for his constructive guidance.

\section{References}

Begon, M.,. Harper, J.L. and Townsend, C.R. 1996. Ecology: individuals, populations and communities - Blackwell Science, Oxford. $1068 \mathrm{p}$.

Brodersen, K.P. and Anderson, N.J. 2002. Distribution of chironomids (Diptera) in low arctic West Grenland lakes: trophic conditions, temperature and environmental reconsruction - Freshwater Biology 47: 1137-1157.

Brotskaya, V.A. and Zenkevich, L.A. 1939. Quantitative assessment of bottom fauna in the Barents Sea - Papers of the VNII for fishery and oceanography 4: 5-98.

Crozet, B.L., Lencioni, V., Ólafsson, J.S., Snook, D.L., Velle, G., Brittain, J.E., Castella, E. and Rossaro, B. 2001. Chironomid (Diptera: Chironomidae) communities in six European glacier-fed streams - Freshwater Biology 46: 1791-1809.

Karabanov, Ye.B. and Kulishenko, Yu.L. 1990. Effect of waves on the distribution of benthic organisms. In: K.M. Petrov (ed) Underwater landscapes of Lake Baikal - Nauka Press, Novosibirsk, pp. 97-112.

Konstantinov, A.S. 1986. General hydrobiology M.: Vyssh. shk., pp. 286-295.

Kozhova, O.M. and Kravtsova, L.S. 1998. Chironomidae of Lake Baikal in the area of human impact. In: Pleshanov, A.S. (ed). Entomological Problems of Baikalian Siberia - Novosibirsk: Nauka, pp. 39-43.

Kravtsova, L.S. and Yerbayeva, E.A. 1990. Species diversity and distribution of Chironomidae in the area Utulik - Morino Biologia vnutrennikh vod 88: 47-51.

Kozhova, O.M., Erbaeva Ye.A. and Safronov, G.P. 2000. The Benthic Invertebrates of Lake Khubsugul, Mongolia. In: A. Rossiter and $\mathrm{H}$. Kawanabe (eds) Ancient Lakes: Biodiversity, Ecology and Evolution. Ecological research. Tokyo, pp. 97-124.
Kravtsova, L.S. 1991. Zoobenthos in the system of hydrobiological monitoring on Lake Baikal -PhD Thesis, Irkut.Univ., Irkutsk. 24 p.

Kravtsova, L.S., Gorbunova, L.A., Izhboldina, L.A. and Karabanov, Ye. B. 1999.

Chironomidae communities of sub-aqual landscape in shallow water zone in Southern Baikal. In: Mironov, A.G. (ed). Geochemistry of Landscapes, Paleoecology of Man and Ethnogenesis. Abstract of the International Symposium - Ulan-Ude, pp. 326-328.

Kravtsova, L.S. 2005. Spatial distribution of chironomids (Diptera, Chironomidae) in habitats of Lake Baikal and its tributaries Euroasian Entomol. J. 4(1): 81-85.

Kravtsova, L.S., Kamaltynov, R.M., Karabanov, E.B., Mekhanikova, I.V., Sitnikova., T.Ya Rozhkova, N.A., Slugina, Z.V., Izhboldina, L.A., Weinberg, I.V., Akinshina, T.V. and Sherbakov, D.Yu. 2004. Macrozoobenthic communities of underwater landscapes in the shallow-water zone of southern Lake Baikal Hydrobiologia 522: 193-205.

Kusakin, O.G., Kudryashov, V.A., Tarakanova T.F. and Shornikov, Ye.I. 1974. Belt-forming floral-faunistic assemblages in the littoral zone of the Kuril Islands. In: Zhirmunskiy, A.V. (ed). Plants and animals of the littoral of the Kuril Islands - Nauka Press., Novosibirsk, pp. 5-96.

Lang, C. 2000. Response of oligochaete (Tubificidae and Lumbriculidae) and Diptera Chironomidae communities to the decrease of phosphorous concentrations in Lake Geneva (Little Lake) - Annls de Limnologie International Journ. of Limnology 36(1): 1320

Linevich A.A. 1981. Baikalian and Pre-Baikalian chironomids.- Novosibirsk: Nauka. 152 p.

Odum, E. P. 1971. Fundamentals of ecology. 3rd edition. Saunders, Philadelphia. 574 p.

Samburova, V.A. 1982. Chironomidae. In: Kozhova, O.M. (ed). State of Communities in Southern Baikal - Irkutsk: Irkutsk State University, pp. 94-104.

Scrimgeour, G.J., Tonn, W.M., Paszkowski, C.A. and Goater, C. 2001. Benthic macroinvertebrate biomass and widfires: evidence for enrichment of boreal subarctic lakes - Freshwater Biology 46(3): 367-378. 
Shapovalova, I.M. 1969. Chironomidae at stony littoral of Lake Baikal - Gidrobiol. zhurn. 1: $60-63$.

Slugina, Z.V., Kamaltynov, R.M., Karabanov, Ye.B. and Kravtsova, L.S. 1995. Bivalve (Bivalvia) distribution patterns in the shallow waters of southern Lake Baikal - Zool. zhurn. 74: 27-41.

Pastukhova, Ye.V., Bakhtina V.I., Miroshnichenko, M.P., Alexebnina, M.S. and Sokolova, N.Yu. 1983. Communities structure. In : Sokolova, N.Yu. (ed). Crank Chironomus plumosus L. (Diptera,
Chironomidae) - Moscow: Nauka, pp. 260274.

Verneaux, V and Verneaux, J. 2002. Assessing lake functioning using the macrobenthic community with special reference to Chironomidae (Diptera). A subalpine lake (Lake Annecy) as an example - Archiv für Hydrobiologie 154(1) : 61-78.

Vorobjov, V.P. 1949. Benthos of Azov Sea Azcherniro Chernomorskogo nauch. issled. in-ta. 3: 100-193.

\title{
Diaheliotaxis and OMbrophobia in An Anthophilous High Arctic Midge, SMITTIA VELUTINA (LUNDBECK, 1898) (CHIRONOMIDAE)
}

\author{
Peter G. Kevan \\ Department of Environmental Biology, University of Guelph, Guelph, Ontario N1G 2W1, Canada \\ Email:pkevan@uoguelph.ca
}

Records of Chironomidae as flower visitors are few (Larson et al. 2001), and explanations of their anthophilous activities even fewer. In the Arctic, several species are known as flower visitors and nectariphages (McApline, 1965; Oliver, 1968; Hocking, 1968; Kevan, 1970; 1973; Larson et al. 2001), but none so abundant and conspicuous as Smittia velutina.

Smittia velutina is a common, early emerging species of Chironomidae in the High Arctic (Danks 1981). It seems to be parthenogenetic. Males are so far not recorded and females I kept in vials oviposited on the inside walls. One of the interesting features of this insect is its anthophily, or flower visiting habits. Oliver (1968) also recorded this species (of only two Chironomidae in the High Arctic) as nectariphagous. Large numbers can be found on the first summer blooms of Saxifraga oppositifolia L. (Saxifragaceae) and of Salix arctica Pall. (Salicaceae). I found them with their mouthparts at the nectaries of flowers of both species of plants, and few on a few others (Kevan 1970). My observations were almost exclusively from staminate catkins $S$. arctica, but both McAlpine (1965) and Hocking (1968) recorded them from pistillate catkins.

During my studies in insect and flower relations in the Canadian High Arctic (Kevan 1970; 1972; 1973), I was able to collect large numbers of $S$. velutina from flowers and made the following discoveries. All findings reported herein are from
Hazen Camp, Ellesmere Island, Nunavut ( 89 49' N., 71 18’ W).

Between 31 May and 23 July, 1967 I collected 337 females from flowers. They were dissected to examine their gut contents and the state of their ovarian development (Harlow 1956). Almost all had guts distended with clear, syrupy liquid. None had ingested pollen grains. Two thirds (65\%) of those dissected had well developed ovaries, with ovarioles at Stage 3 of development. Ten percent had ovaries at Stage 2, and $16 \%$ at Stage 4. Those with Stage 1 and spent ovaries numbered only 3 and $4 \%$ respectively.

Oliver (1968) noted that 9 of the species he studied emerged with ovaries almost mature (Stage 3) or mature. He did not report on $S$. velutina, but indicated that in the species he studies that ovarian maturation from almost to fully mature (Stage 4) takes about 3 days. Given the duration of anthophily I recorded, with a peak from 1 to 15 June, I postulate that the cohorts of midges I observed in the flowers were constantly changing. That idea was strengthened by observations on the daily pattern of abundances of $S$. velutina on the flowers of $S$. oppositifolia.

From combined observations from 1966 and 1968, I determined that about $64 \%$ of the midges were in flowers on the insolated sides of clumps of S. oppositifolia (Figure 1). That observation suggests strongly that the insects were continually 
changing their orientation and following the warmth of the sun (i.e. were exhibiting diaheliotaxis). I did not make precise measurements of the shapes of the clumps of flowers, nor of the insolated proportion of the clumps from which the observation came. Thus, a complete statistical analysis can not be made to test the hypothesis implied in the above. I leave that to someone else.

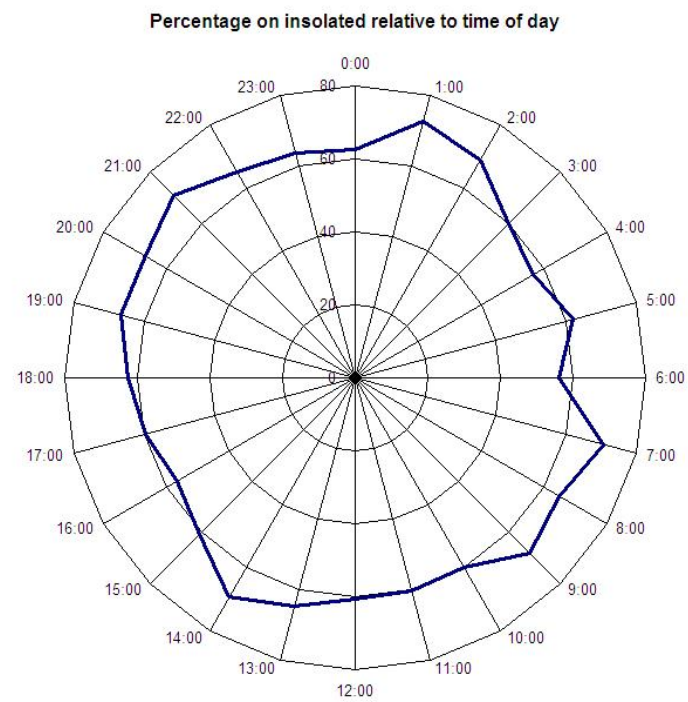

Figure 1. The percentage of the observed population of Smittia velutina within fully insolated flowers of Saxifraga oppositifolia throughout a composite day of 24 hours of sunshine (Data summarized from summers 1966 to 1968 at Hazen Camp, Ellesmere Island, Nunavut)

In respect of the benefits of arctic insects' basking in flowers, the most studies have been made on temperature regimes in the diaheliotropic flowers of Dryas integrifolia (Vahl.) (Rosaceae) and Papaver radicatum Rottb. (Papaveraceae) (Hocking and Sharplin, 1965; Kevan 1975). Those studies indicate two-fold benefits, one to the insects (warmth and protection) and the other to the plants (pollinator attraction, increased speed of pollen tube growth following pollination, more rapid fertilization of the ovules and growth of the seeds and fruits). Although $S$. oppositifolia is not diaheliotropic, its flowers become warmed by insolation. Figure 2 shows the amount of warmth (temperature above ambient air in the vicinity of the flowers) within its flowers according to the angle of insolation. Small insects, such as $S$. velutina, would assume the temperature of the environment within the flowers in which they rested. Thus, the two-fold benefit of insolational warming of the flowers of $S$. oppositifolia would be the same as for $D$. integrifolia and $P$. radicatum, but for shorter durations. The insects could extend the duration of their benefit by circumnavigating the clumps and so remaining insolated and warm. Using the same approach as in Kevan (1975) one can calculate roughly that the adult midges might gain as much as $25 \%$ more heat units by this
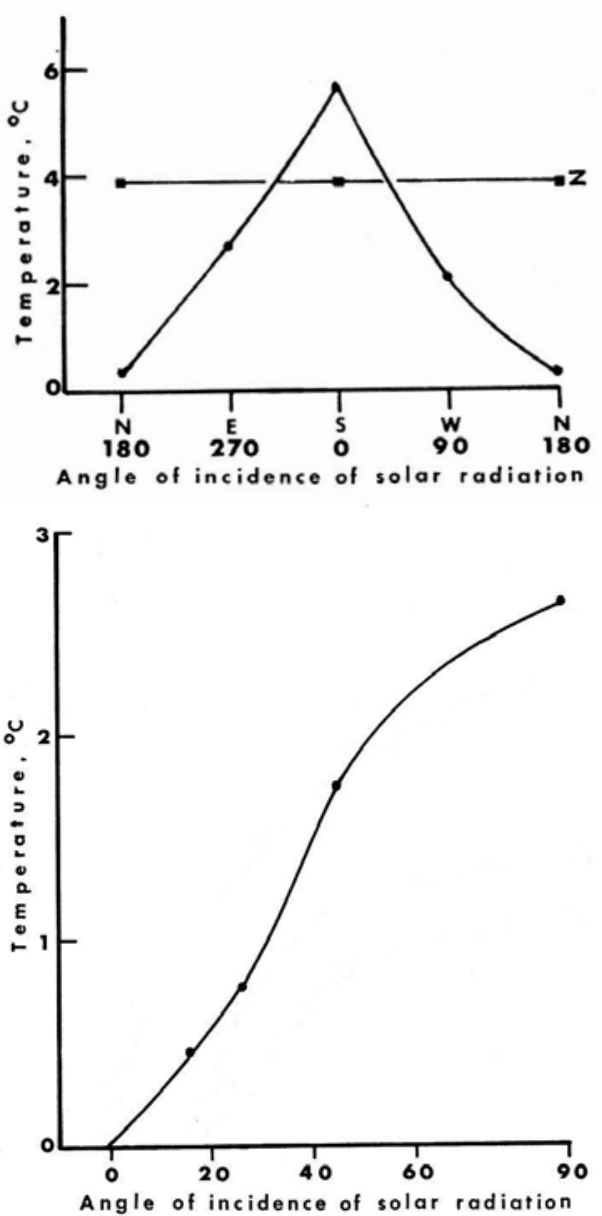

behaviour. Such thermally advantageous circumnavigation (Kevan 1989) is known for mosquito larvae in tundra ponds (Haufe, 1957), woolly bear caterpillars on hummocks of vegetation (Kevan et al. 1981; Kukal et al. 1988) and diaheliotropic flowers (Kevan 1975).

Figure 2. Top: Temperature within and at the bases of the flowers of Saxifraga oppositifolia (where Smittia velutina was observed feeding on nectar) above ambient air temperature with respect to the direction of the sun on a still sunny day at solar noon. Flowers at S (0) were open directly to incoming insolation, at $\mathrm{N}$ (180 ) open directly away from the sun, $\mathrm{Z}$ is for temperatures of flowers open directly to the Zenith.

Bottom: Temperature within and at the base of flowers of Saxifraga oppositifolia (where Smittia velutina was observed feeding on nectar) above 
ambient air temperature with respect to the direction of the sun as they were tipped from facing directly into the sun (90 equivalent to 0 in the left-hand graph) to a position so that the sun's rays glanced across the top of the open flowers.

Although rain is uncommon around Lake Hazen, from 22 to 24 June, 1966 light rains fell and observations on the insects in $S$. oppositifolia were made. At each observation between 104 and 127 midges were counted. Close inspection revealed that $S$. velutina used the flowers as umbrellas. Only one hour after the rain had started, many flowers were empty, but $65 \%$ of the midges had taken refuge beneath the flowers. Thirteen hours later, $80 \%$ of the midges associated with the flowers were underneath them. Thus, the midges were exhibiting avoidance of rain, or ombrophobia. After the rain ceased and the sun had shone, the midges slowly resumed their positions in the flowers, so that after 14 hours of sunshine $89 \%$ of the midges were within the corollas, and only $11 \%$ still beneath them.

Acknowledegements: I am grateful to the late Professor Brian Hocking who encouraged my research by providing funds from his research grants. The Canadian Defence Research Board helped through allowing use of Hazen Camp and providing logistic support. I thank Marianna Horn for kindly helping me with preparation of the figures. Torbjørn Ekrem and Elisabeth Stur pushed me to write this short article; thank you.

\section{References}

Danks, H.V. 1981. Arctic Arthropods: A review of systematics and ecology with particular reference to the North American fauna. Entomological Society of Canada, Ottawa. 608 pp.

Harlow, P.M. 1956. A study of the ovarial development and its relation to adult nutrition in the blowfly Protophormia terraenovae (R. D.). - Journal of Experimental Biology 33: 777 - 797

Haufe, W.O. 1957. Physical environment and behaviour of immature stages of Aedes communis (Deg.) in subarctic Canada. Canadian Entomologist 89: 120 - 139.
Hocking, B. 1968. Insect-flower associations in the high arctic with special reference to nectar. - Oikos 19: 359 - 388.

Hocking, B. and Sharplin, C.D. 1965. Flower basking by arctic insects. - Nature (London) 206: 215

Kevan, P.G. 1970 High Arctic Insect-Flower Relations: The Inter-relationships of Arthropods and Flowers at Lake Hazen, Ellesmere Island, N.W.T., Canada. Ph. D. Dissertation, University of Alberta, Edmonton, Alberta, Canada.

Kevan, P.G. 1972. Insect pollination of High Arctic flowers. - Journal of Ecology 60: 813-847.

Kevan, P.G. 1973. Flowers, insects, and pollination ecology in the Canadian High Arctic. - Polar Record 22: 667-674.

Kevan, P.G. 1975. Sun-tracking solar furnaces in high arctic flowers: significance for pollination and insects. - Science (Washington) 189: 723-726.

Kevan, P.G., Jensen, T.S. and Shorthouse, J.D. 1981. Body temperatures and behavioural thermoregulation of high Arctic woolly-bear caterpillars and pupae (Gynaephora rossii, Lymantriidae: Lepidoptera) and the importance of sunshine. - Arctic and Alpine Research 14: 125-136.

Kevan, P.G. 1989. Thermoregulation in arctic insects and flowers: Adaptations and coadaptations in behaviour, anatomy, and physiology. In: Mercer, J.B. (ed.) Thermal Physiology. Elsevier Science Publishers. pp. $747-753$.

Kukal, O., Heinrich, B. and Duman, J.G. 1988. Behavioral thermoregulation in the freezetolerant arctic caterpillar Gynaephora groenlandica. - Journal of Experimental Biology 138: 181 - 193.

Larson B.M.H., Kevan, P.G. and Inouye, D.W. 2001. Flies and flowers: taxonomic diversity of anthophiles and pollinators. - Canadian Entomologist 133: 439-465.

Oliver, D.R. 1968. Adaptations of Arctic Chironomidae. - Annales Zoologici Fennici 5: 111 - 118.

McAlpine, J.F. 1965. Observations on anthophilous Diptera at Lake Hazen, Ellesmere Island. - Canadian FieldNaturalist 79: 247 - 252. 


\title{
Chironomids of The Yucatán Peninsula
}

\author{
Evgenia M. Vinogradova and H. Wolfgang Riss \\ Department of Limnology, Institute for Evolution and Biodiversity, University of Muenster \\ Email:vinogradova@uni-muenster.de,riss@uni-muenster.de
}

\section{Introduction}

One of the many areas of the globe, where the chironomid fauna has practically not been studied yet, is the Yucatán peninsula. It is vast and mostly plain lowland marking the southern border of the Mexican Gulf. The geological history of Yucatán is linked in many ways with that of the Caribbean and Central America (Iturralde-Vinent and MacPhee 1999). In biogeographical terms, Yucatán belongs to the Neotropical region and the Caribbean subregion (Morrone 2006). Occurrence of endemisms seems to justify a subdivision in three more areas (Espadas et al. 2003). To date, studies of chironomid communities in Central America concentrated mainly on the mountainous reaches along the cordillera ridges and volcano foothills (e.g. Coffman et al. 1992; Watson and Heyn 1992; Sublette and Sasa 1994).

The study presented here is part of a major research project. Its purpose is to estimate the importance of climatic and geogene factors for the taxonomic composition of chironomid communities in lakes of the peninsula. A preliminary overview on the chironomid diversity of this region is given in this article.

\section{Sampling sites and methods}

18 lowland lakes, differing in basin morphometry, anthropogenous impact, and chemical properties, were studied in the lowland (up to $150 \mathrm{~m}$ a.s.l.) of Yucatán. The lake basins are embedded in limestone and gypsum karst and scattered across a NE-SW precipitation gradient from 600 to 1900 $\mathrm{mm} \mathrm{a}^{-1}$. Some of the lakes communicate hydrologically with the mangrove belt of the coastline through a diffuse net of canals. Immature chironomids were sampled from the sediment surface layer at maximum lake depth (SMD) and in the littoral from surface drift and various firm substrates. Adults were caught with an insect net from emerging plants and in a light trap after sunset. So far, larval head capsules, given in individuals per gram dry sediment $\left(\mathrm{g}^{-1}\right)$, and male adults were analyzed. Littoral samples await processing. Environmental predictors include 31 parameters for lake morphometry, lithology, physico-chemical analyses, littoral morphology, hinterland use, and anthropogenic disturbance.

\section{First results and considerations}

To date, 84 taxa (mainly morpho-species) out of 48 chironomid genera have been identified on the basis of head capsules from SMD and adult males from all 18 lakes (Tab. 1). Eight genera belonged to the Tanypodinae, only two genera to the Orthocladiinae, and the majority, i.e. 38, to the Chironominae (29 Chironomini, 9 Tanytarsini). The dominant taxa that occurred in all lakes were Cladopelma lateralis and Tanytarsus species (this genus probably comprises a greater number of morpho-species than separated here). Further on, Chironomus, Goeldichironomus, Polypedilum, Cladotanytarsus, Labrundinia, Natarsia, Procladius were present in more than $70 \%$ of the lakes. The most abundant genera, reaching abundances of 4 to $10 \mathrm{~g}^{-1}$, were Labrundinia, Natarsia, Cladopelma, Microtendipes, Xenochironomus, Cladotanytarsus, and Tanytarsus. Mean taxa number from SMD was 14.4, whereat greatest diversity was found in Lake Yaxha (20) and Gravel Pond (19), lowest in Honey Camp Lagoon (7) and Lake Chichancanab (9). Median total abundance of head capsules from SMD was $53.5 \mathrm{~g}^{-1}$. Density was exceptionally high in Punta Laguna (1033 $\left.\mathrm{g}^{-1}\right)$, moderate in Honey Camp Lagoon $\left(174 \mathrm{~g}^{-1}\right)$, Cenote $\left(172 \mathrm{~g}^{-1}\right)$ and extremely low, however, in Lake Izabal $\left(0.81 \mathrm{~g}^{-1}\right)$.

The slope of the species-area relationship indicated that about 50 to $60 \%$ of the estimated chironomid diversity of Yucatán lowland lakes was covered by the list above. For most of the taxa, marked out as morpho-species, no taxonomic descriptions exist. The number of taxa is expected to rise further when data from littoral immatures and all adults are included. However, a certain drawback is the fact that explicit combinations of the metamorphic stages can be attained only under reserve. 
Relatively low SMD head capsule abundance in Yucatán lakes, in comparison to temperate lakes, may have several reasons: 1) The lakes studied, like most shallow lakes of the (Sub-)Tropis, are holomictic and thus sedimentation is disturbed by turbulence, which causes head capsules to disaggregate more likely. 2) Sedimentation rates are increased owing to both inflow of allochtonous inorganic suspended matter from affluents, mainly during the rain periods, and/or high autochtonous production conditioned by lake morphometry and/or anthropogenic alterations. 3) Durability of the sediment may be reduced due to precipitation and redilution processes of the geogene gypsum. Consequently, time-consuming analysis of low-density material did not help promoting the taxonomic gain.

A view on numerical attributes revealed that both, number of taxa and equitability (evenness) of the communities tended to decrease towards higher latitudes, at which SMD abundances, however, increased significantly with the probability of drought events occurring. Number of taxa was highest in eutrophic conditions. Correspondence analyses showed that the most important environmental predictors, besides trophic state of the lakes and mean annual precipitation, were concentration of gypsum $\left(\mathrm{CaSO}_{4}\right)$ and salinity (predominantly $\mathrm{NaCl}$ ), the latter occurring in lakes subject to aperiodical seawater infiltration. Surprisingly, morphometric properties, such as littoral formation, lake surface area, and average lake depth were of subordinate explanatory value for the community structure.

Expectations of finding a high ratio of species versus genera were supported by assumptions from biogeography and evolutionary history. Central America is a relatively young land bridge, which gave way to a radiation from both Americas (Bănărescu 1995). Colonization of aquatic habitats and ecological niching in process is assumed to be reflected in a relatively great taxonomic depth (Coffman et al. 1992).

The biogeographic position of chironomids of the Yucatán peninsula can be determined with some certainty. Studies of taxa assemblages, including descriptions of new species, exist for Costa Rica (Coffman et al. 1992; Watson and Heyn 1992; Andersen 1996; Epler 1996a, b), Nicaragua (Palomaki 1987; Ráudez Reyes 2004), Guatemala (Sublette and Sasa 1994), and Mexico (Epler 1987; Contreras-Ramos and Andersen 1999; Andersen et al. 2000, Andersen and Mendes 2002; Kyerematen and Andersen 2002). Other works (e.g. Borkent 1984; Spies and Reiss 1996; Mendes et al. 2004) refer to entire Central America and beyond.

Table 1. Chironomid taxa recorded from lakes of Yucatán peninsula (l: larva, a: adult)

\begin{tabular}{llll}
\hline Taxon & Stage & Taxon & Stage \\
\hline Ablabesmyia sp. & $\mathrm{l}$ & Nilothauma sp. & $\mathrm{l}$ \\
Ablabesmyia cinctipes & $\mathrm{a}$ & Oukuriella c.f. simulatrix & $\mathrm{a}$ \\
Coelotanypus sp.1 & $\mathrm{l}$ & Paracladopelma sp. & $\mathrm{l}$ \\
Coelotanypus sp.2 & $\mathrm{l}$ & Paralauterborniella sp. & $\mathrm{l}$ \\
Fittkauimyia sp. & $\mathrm{l}$ & Paratendipes sp.1 & $\mathrm{l}$ \\
Labrundinia sp. & $\mathrm{l}$ & Paratendipes c.f. subaequalis & $\mathrm{l}$ \\
Labrundinia fosteri & $\mathrm{a}$ & Parachironomus sp. & $\mathrm{l}$ \\
Natarsia sp. & $\mathrm{l}$ & Parachironomus directus & $\mathrm{a}$ \\
Nilotanypus sp. & $\mathrm{l}$ & Pedionomus sp. & $\mathrm{l}$ \\
Procladius sp. & $\mathrm{l}$ & Pedionomus curticaudatus & $\mathrm{a}$ \\
Tanypus c.f. mopunctipens & $\mathrm{l}$ & Phaenopsectra sp. & $\mathrm{l}$ \\
c.f. Tanypus sp.A & $\mathrm{l}$ & Polypedilum sp. & $\mathrm{l}$ \\
Nanocladius sp. & $\mathrm{l}$ & Polypedilum purus & $\mathrm{a}$ \\
Cricotopus sp. & $\mathrm{a}$ & Polypedilum sp.A & $\mathrm{a}$ \\
Apedilum sp. & $\mathrm{l}$ & Polypedilum sp.B & $\mathrm{a}$ \\
Apedilum subcinctum & $\mathrm{a}$ & Polypedilum sp.C & $\mathrm{a}$ \\
Apedilum elachisto & $\mathrm{a}$ & Polypedilum sp.D & $\mathrm{a}$ \\
Asheum curticaudatus & $\mathrm{a}$ & Polypedilum sp.E & $\mathrm{a}$ \\
Axarus sp. & $\mathrm{l}$ & Polypedilum sp.F & $\mathrm{a}$ \\
Beardius sp. & $\mathrm{l}$ & Pseudochironomus sp. & $\mathrm{a}$ \\
Beardius aciculatus & $\mathrm{a}$ & Saetheria sp. & $\mathrm{l}$ \\
Fissimentum sp. & $\mathrm{l}$ & Xenochironomus sp. & $\mathrm{l}$ \\
Chironomus sp.1 & $\mathrm{l}$ & Zavreliella sp. & $\mathrm{l}$ \\
Chironomus sp.2 & $\mathrm{l}$ & Zavreliella longiseta & $\mathrm{a}$ \\
\hline
\end{tabular}




\begin{tabular}{llll}
\hline Taxon & Stage & Taxon & Stage \\
\hline Cladopelma sp.1 & $\mathrm{l}$ & Caladomyia pistra sp. & $\mathrm{a}$ \\
Cladopelma sp.2 & $\mathrm{l}$ & Cladotanytarsus sp.1 & $\mathrm{l}$ \\
Cladopelma forcipis & $\mathrm{a}$ & Cladotanytarsus sp.A & $\mathrm{a}$ \\
Cryptochironomus sp. & $\mathrm{l}$ & Micropsectra sp. & $\mathrm{l}$ \\
Cryptochironomus sp.A & $\mathrm{a}$ & Nimbocera sp. & $\mathrm{l}$ \\
Cryptochironomus sp.B & $\mathrm{a}$ & Paratanytarsus sp. & $\mathrm{l}$ \\
Dicrotendipes sp. & $\mathrm{l}$ & Stempellina sp. & $\mathrm{l}$ \\
Dicrotendipes c.f. sinoposus & $\mathrm{a}$ & Stempellinella sp.1 & $\mathrm{l}$ \\
Einfeldia sp. & $\mathrm{l}$ & Stempellinella sp.2 & $\mathrm{l}$ \\
Glyptotendipes sp. & $\mathrm{l}$ & Stempellinella sp.3 & $\mathrm{l}$ \\
Goeldichironomus sp.1 & $\mathrm{l}$ & Sublettea sp. & $\mathrm{l}$ \\
Goeldichironomus sp.2 & $\mathrm{l}$ & Tanytarsus sp.1 & $\mathrm{l}$ \\
Goeldichironomus amazonicus & $\mathrm{a}$ & Tanytarsus sp.2 & $\mathrm{l}$ \\
Goeldichironomus carus & $\mathrm{a}$ & Tanytarsus sp.3 & $\mathrm{l}$ \\
Goeldichironomus holoprasinus & $\mathrm{a}$ & Tanytarsus sp.4 & $\mathrm{l}$ \\
Hyporhygma sp. & $\mathrm{l}$ & Tanytarsus hastatus & $\mathrm{a}$ \\
c.f. Lipinella sp. & $\mathrm{l}$ & Tanytarsus sp.A & $\mathrm{a}$ \\
Microchironomus sp. & $\mathrm{l}$ & Tanytarsus sp.B & $\mathrm{a}$ \\
Microtendipes sp. & $\mathrm{l}$ & Tanytarsus sp.C & $\mathrm{a}$ \\
\hline
\end{tabular}

However, comparability of the aforementioned studies with ours suffered from certain limitations. On the one hand, those studies were carried out at different geographic altitudes, thus covering the range from tropical to temperate fauna. On the other, only rough descriptions of the habitat types, samples were taken from, were given, often mingling captures from running and still waters. The occurrence of Orthocladiinae, being well represented in those other studies, entailed low taxonomic overlap with our data, not exceeding 50 percent on the generic level. Consequently, the chironomid fauna from a nearby site in Guatemala (Sublette and Sasa 1994) most closely resembled that from the northern Andes of Colombia (Riss and Ospina 2000). And the so far only record from the central lowlands of Yucatán (Contreras-Ramos and Andersen 1999) displayed a generic correspondence with our data of 64 percent - not more than comparison with the chironomid list for northern Colombia (Nazarova et al. 2004). Latter findings indicate that the chironomids of the entire Yucatán lowland can be regarded as a circum-Caribbean element.

Comparative analyses of existing record lists were limited due to ambiguity or absence of pertinent complementary information about sample habitats in most of the chironomid field studies referred to here. Generally spoken, better comparability of study results would allow for means and goals to an advanced level, such as ecological meta-analyses or biogeographic diagnoses. This conclusion also may be understood as a plea for stronger consideration of simple but useful ecological specifications of sample habitats to be given along with future chironomid field records.

\section{Acknowledgements}

This study was financially supported by the German Research Foundation (DFG). The authors express their gratitude to Martin Spies for helpful advices and to their co-operating colleagues Antje Schwalb, Burkhard Scharf and Liseth Pérez.

\section{References}

Andersen, T. 1996. New species of Diplosmittia Sæther, 1981 from Costa Rica (Chironomidae, Orthocladiinae). - Acta zool. Acad. Sci. Hung. 42: 127-132.

Andersen, T., Contreras-Ramos, A., and Spies, M. 2000. Chironomidae. - In: Bousquets J.L., Garcia Aldrette, A.N. González Sorina, E. (eds.): Biodiversidad, taxonomía y biogeografía de artrópodos de México: Hacia una síntesis de su conocimiento. Vol 2, pp. 581-591. Universidad Nacional Autónomia de México, Mexico.

Andersen, T. and Mendes, H.F. 2002. Neotropical and Mexican Mesosmittia Brundin, with the description of four new species. - Spixiana 25: 55-69.

Andersen, T. and Mendes, H.F. 2002. New species and records of the Axarus "rogersigroup" from South and Central America (Diptera, Chironomidae). - Acta Zoologica 
Academiae Scientiarum Hungaricae 48: 3540.

Bănărescu, P. 1995. The Central American/Caribbean intermediary areas. In: Bănărescu, P.: Zoogeography of fresh waters. Vol.3, pp. 1256-1282. AULA-Verlag.

Borkent, A. 1984. The systematics and phylogeny of the Stenochironomus Complex (Xestochironomus, Harrisius and Stenochironomus) (Diptera: Chironomidae). - Mem. Entom. Soc. Can. 128: 269 pp.

Coffman, W.P., de la Rosa, C., Cummins, K.W. and Wilzbach, M.A. 1992. Species richness in some Neotropical (Costa Rica) and Afrotropical (West Africa) lotic communities of Chironomidae (Diptera). - Netherl. J. Aqu. Ecol. 26: 229-237.

Contreras-Ramos, A. and Andersen, T. 1999. A survey of the Chironomidae (Diptera) of Calakmul Biospere Reserve, Mexico. Chironomus 12: 3-4.

Epler, J.H. 1987. Notes on the Dicrotendipes (Diptera: Chironomidae) of Mexico, with descriptions of two new species. - Ent. Scand. Suppl. 29:147-154

Epler, J.H. 1996a. New species of Oukuriella Epler (Diptera: Chironomidae) from Costa Rica. - Hydrobiologia 318: 3-11.

Epler, J.H. 1996b. A new species of Dicrotendipes Kieffer (Diptera: Chironomidae) from Costa Rica. Hydrobiologia 318: 13-15.

Espadas, C., Duran, R. and Argáez, J. 2003. Phytogeographic analysis of taxa endemic to Yucatán Peninsula using geographic information systems, the domain heuristic method and parsimony analysis of endemicity. - Diversity and Distributions 9: 313-330.

Iturralde-Vinent, M. and MacPhee, R. 1999. Paleogeography of the Caribbean region, implications for Cenozoic biogeography. Bull. Amer. Mus. Nat. Hist. 238: 1-95.

Kyerematen, R.A.K. and Andersen, T. 2002. Rheotanytarsus Thienemann et Bause (Diptera: Chironomidae) from Central America and Mexico. - Studies on
Neotropical Fauna and Environment 37: 2351.

Mendes, H.F., Andersen, T., and Sæther, O.A. 2004. A review of Antillocladius Sæther, 1981; Compterosmittia Sæther, 1981 and Litocladius new genus (Chironomidae, Orthocladiinae). - Zootaxa 594: 1-82.

Morrone, J.J. 2006. Biogeographical areas and transition zones of Latin America and the Caribbean Islands based on pangeographic and cladistic analyses of the entomofauna. Annu. Rev. Entomol. 51: 467-494.

Nazarova, L.B., Riss, H.W., Kahlheber, A. and Werding, B. 2004. Some Observations of buccal deformities in chironomid larvae (Diptera: Chironomidae) from the Ciénaga Grande de Santa Marta, Colombia. Caldasia 26: 275-290.

Palomaki, R. 1987. The Chironomidae of some lakes and rivers in Nicaragua. - Ent. Scand. Suppl. 29: 45-49.

Ráudez Reyes, S.M. 2004. Presencia de la Familia Chironomidae en la entrada del Río San Juan y cuatro de sus tributarios. - XIII Congr. Cient.: 6 pp. Univ. Nac. Autón. Nicaragua, Managua.

Riss, H.W. and R. Ospina. 2000: Taxonomic and ecological inventory of Chironomidae (Diptera) from the andine highlands of Colombia - First results of a scientific development project. - In: Hoffrichter, O. (Ed.): Late 20th century research on Chironomidae, pp. 615-620. Shaker, Aachen.

Spies, M. and Reiss, F. 1996. Catalog and bibliography of Neotropical and Mexican Chironomidae (Insecta, Diptera). - Spixiana Suppl. 22: 61-119.

Sublette, J.E. and Sasa, M. 1994. Chironomidae collected in Onchocerciasis endemic areas of Guatemala (Insecta, Diptera). - Spixiana Suppl. 20: 1-60.

Watson Jr., C.N. and Heyn, M.W. 1992. A preliminary survey of the Chironomidae (Diptera) of Costa Rica, with emphasis on the lotic fauna. - Netherl. J. Aqu. Ecol. 26: 257-262. 


\title{
NEW RECORDS OF CHIRONOMIDAE (DIPTERA) FROM CONTINENTAL FRANCE
}

\author{
Joel Moubayed-Breil \\ Applied ecology, 10 rue des Fenouils, 34070-Montpellier, France, \\ Email:jm.aquabiol@neuf.fr
}

\begin{abstract}
Material recently collected in Continental France has allowed me to generate a list of 83 taxa of chironomids, including 37 new records to the fauna of France. According to published data on the chironomid fauna of France 718 chironomid species are hitherto known from the French territories. The nomenclature and taxonomy of the species listed are based on the last version of the Chironomidae data in Fauna Europaea, on recent revisions of genera and other recent publications relevant to taxonomy and nomenclature.
\end{abstract}

\section{Introduction}

French territories represent almost the largest variety of aquatic ecosystems in Europe with respect to both physiographic and hydrographic aspects. According to literature on the chironomid fauna of France, some regions still are better sampled then others, and the best sampled areas are: The northern and southern parts of the Alps (regions 5a and 5b in figure 1); western, central and eastern parts of the Pyrenees (regions 6, 7, 8), and South-Central France, including inland and coastal rivers (regions 9a and 9b). The remaining regions located in the North, the Middle and the South-East of France have received little attention and are still only partially explored and need to be prospected more in the years to come.

According to published data accumulated since 1991 there are 681 registered species from France (Serra-Tosio and Laville 1991, Laville and SerraTosio 1996, Moubayed et al. 2000, Garcia and Laville 2000, Delettre 2001, Sæther and Spies 2004). In the current paper, I give a complementary checklist of new records on the basis of recent field work throughout Continental France over the last two decades. The habitats sampled include high altitude peat pits, springs and streams, mountain lakes and reservoirs, temporary streams and pools. Fully developed pharates, adults, pupae, pupal exuviae and larvae were sampled from chironomid populations throughout the various geographic regions.

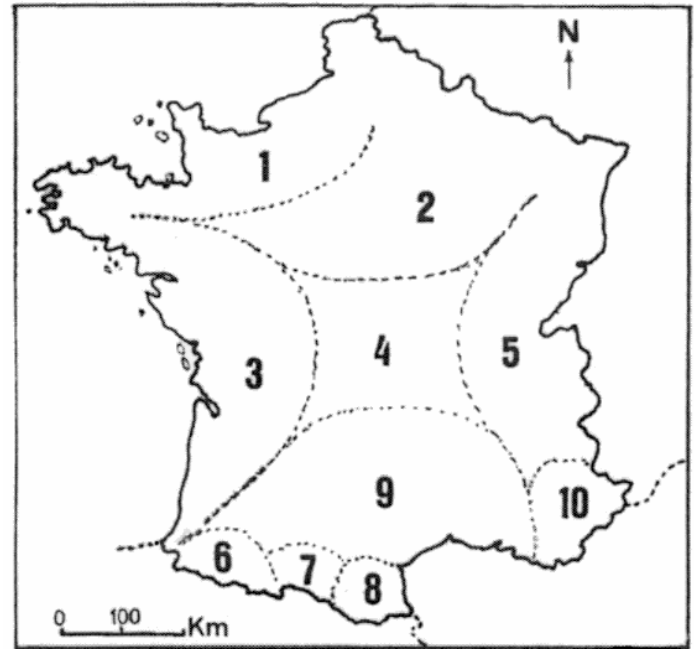

Figure 1. Major biogeographic regions and subregions of France

\section{Sites and methodology}

The identification of slide mounted specimens was aided by recent taxonomic revisions and keys to adults or pupal exuviae (Reiss and Säwedal 1981; Tuiskunen 1986; Serra-Tosio 1989; Sæther 1990; Soponis 1990; Langton 1991; Sæther and Wang 1995; Kyerematen and Sæther 2000; Michiels and Spies 2002; Vårdal et al. 2002; Langton and Visser 2003; Sæther and Spies 2004; Stur and Ekrem 2006; Ekrem 2006; Ekrem 2007) as well as of recent general recommendations on taxonomy and nomenclature (Sæther and Ferrington 2003; Spies and Sæther 2004). Previous geographical distribution of the species was based on the last version of the Chironomidae data in Fauna Europaea (Sæther and Spies 2004), on the latest unpublished data for Fauna Europaea (Sæther and Spies pers comm.), as well as on the taxonomic publications listed above.

The collection sites were located in the ten major physiographic and biogeographic regions and subregions of France (Corsica not included, Figure 1). The habitats sampled include springs, permanent and temporary streams and pools, peat pits, rhithral and potamal of rivers, estuaries, lakes and ponds. An informative map on the biogeographic regions of France is also given by 
Serra-Tosio and Laville (1991). Within the ten prospected regions, two are located in northern France (1 and 2), three in central-south and central France (3, 5 and 4) and five (6, 7, 8, 9 and $10)$ in southern France. The geographic delimitation of the ten regions and subregions is:

- 1, North-West France, including both the Channel and the North Sea coastal streams (1a) and potamic parts of the Seine river basin (1b).

- 2, North-East France, rivers located in the plain and piedmont including the upper stream of the Seine river basin.

- 3, Central-South-West France, including both the Atlantic coastal rivers from the northern part (3a) to the southern part (3b).

- 4, Central-France, including the upper stream and rhithral of the Sioule river basin located in the volcanic region of Auvergne (4a); the upper stream of both Allier river and Loire river basin and surrounding piedmont and lowland wetland areas below $1000 \mathrm{~m}$ (4b).

- 5, Central-East France, including the upper stream of the Rhone river basin (5a) and the Alpes (especially located in high and middle mountain areas, 5b).

- 6, 7 and 8, French part of the Pyrenees and PrePyrenees, including Western-Pyrenees (6), Central-Pyrenees (7) and Eastern-Pyrenees (8). Pyrenees consist of both mountain and high mountain rivers (6a, 7a, 8a), Pre-Pyrenees consist only of piedmont and mountain rivers $(6 \mathrm{~b}, 7 \mathrm{~b}$, 8b).

- 9, South-Central France, including both the inland rivers of the northern part (9a) and the coastal Mediterranean rivers of the southern part (9b). Nevertheless, with respect to chironomid fauna, three geographical zones of biogeographical significance have been identified in the Mediterranean region between the Spanish and the Italian borders (Moubayed et al. 2000).

- 10, South-East France, including the Var and Maritime Alp departments.

Sampling methods mainly used were: Surber net for benthos; Brundin drift net for pharates, pupae and pupal exuviae; Troubleau net for individuals floating on the surface of the water; sweep net for adults.

\section{List of species}

In total, material of 83 chironomid taxa was collected throughout the ten biogeographical areas in Continental France since 1980 (Table 1). Among these taxa there were 8 Tanypodinae, 5 Diamesinae, 35 Orthocladiinae and 35 Chironominae (14 Chironomini and 21 Tanytarsini). Based on recent published data on French chironomid communities (Serra-Tosio and

Table 1. List and geographical distribution of species. * = new record for France; ** = undescribed species; $\mathrm{P}$ = present; Im = imago; $\mathrm{N}$ = nymph or pharate; $\mathrm{Pe}=$ pupal exuviae; $\mathrm{L}=$ larva

\begin{tabular}{|c|c|c|c|}
\hline List of species & Record & Stage & Distribution \\
\hline \multicolumn{4}{|l|}{ Tanypodinae (8 species) } \\
\hline Arctopelopia barbitarsis (Zetterstedt) & $\mathrm{P}$ & $\mathrm{Pe}$ & $9 b$ \\
\hline Arctopelopia griseipennis (van der Wulp) & $\mathrm{P}$ & $\mathrm{Pe}$ & $7 b, 8 b, 9 b$ \\
\hline Arctopelopia sp.1 & $* *$ & $\mathrm{Pe}$ & 7b,9a \\
\hline Conchapelopia hittmairorum Michiels \& Spies & $\mathrm{P}$ & $\mathrm{Pe}$ & $2,5 a, 8 b, 9,10$ \\
\hline Procladius crassinervis (Zetterstedt) & $\mathrm{P}$ & $\mathrm{N}, \mathrm{Pe}$ & $1 \mathrm{~b}, 2$ \\
\hline Procladius lugens Kieffer & $*$ & $\mathrm{Im}, \mathrm{N}, \mathrm{Pe}$ & $2,5,9$ \\
\hline Procladius rufovittatus van der Wulp & $*$ & $\mathrm{Pe}$ & $2,8 \mathrm{a}, 8 \mathrm{~b}, 9$ \\
\hline Procladius sp.1 (nr Procladius sp, from Norway) & $* *$ & $\mathrm{Pe}$ & $8 \mathrm{a}$ \\
\hline \multicolumn{4}{|l|}{ Diamesinae (5 species) } \\
\hline Boreoheptagyia rugosa Saunders & $\mathrm{P}$ & $\mathrm{Im}, \mathrm{Pe}$ & $8 b, 10$ \\
\hline Boreoheptagyia sp.1 (near B. rotunda Serra-Tosio) & $* *$ & Im & 10 \\
\hline Diamesa thomasi Serra-Tosio & $\mathrm{P}$ & $\mathrm{Im}, \mathrm{N}, \mathrm{Pe}, \mathrm{L}$ & $7 a, 8 a$ \\
\hline Diamesa veletensis Serra-Tosio & * & $\mathrm{Im}, \mathrm{N}, \mathrm{Pe}, \mathrm{L}$ & $8 a$ \\
\hline Potthastia sp.1 & $* *$ & $\mathrm{Pe}$ & $4 \mathrm{~b}$ \\
\hline \multicolumn{4}{|l|}{ Orthocladiinae (35 species) } \\
\hline Brillia pudorosa Cobo, Gonzales \& Vieira-Lanero & $*$ & $\mathrm{Im}, \mathrm{N}, \mathrm{Pe}$ & $3 b$ \\
\hline Bryophaenocladius scanicus Brundin & $*$ & $\operatorname{Im}$ & 4,8b,9 \\
\hline Bryophaenocladius sp.1 & $* *$ & $\operatorname{Im}$ & $9 b$ \\
\hline Corynoneura gratias Schlee & $\mathrm{P}$ & $\mathrm{N}, \mathrm{Pe}$ & 1a,3a,3b,8a,8b \\
\hline Cricotopus algarum (Kieffer) & $\mathrm{P}$ & $\mathrm{Im}, \mathrm{N}, \mathrm{Pe}$ & $1 \mathrm{a}, 1 \mathrm{~b}, 2,3$ \\
\hline Cricotopus caducus Hirvenoja & $\mathrm{P}$ & $\mathrm{Im}, \mathrm{N}, \mathrm{Pe}$ & 1a,3a,3b,9b \\
\hline
\end{tabular}




\begin{tabular}{|c|c|c|c|}
\hline List of species & Record & Stage & Distribution \\
\hline Cricotopus sp.1 (nr C. levantinus Moubayed \& Hirvenoja) & ** & $\mathrm{N}, \mathrm{Pe}$ & $9 b, 10$ \\
\hline Eukiefferiella bedmari Vilchez-Quero \& Laville & * & Im,Pe & 1a,3a,3b \\
\hline Eukiefferiella brehmi Gowin & * & $\mathrm{Pe}$ & $8 a, 8 b, 9 a, 10$ \\
\hline Euryhapsis fuscipropes Sæther \& Wang & * & $\mathrm{N}, \mathrm{Pe}$ & $6 \mathrm{~b}, 9 \mathrm{~b}$ \\
\hline Georthocladius sp.1 & ** & $\mathrm{Pe}$ & 8a \\
\hline Heterotrissocladius grimshawi Edwards & * & $\mathrm{N}, \mathrm{Pe}$ & $2,5 a, 10$ \\
\hline Heterotrissocladius sp.1 & ** & $\mathrm{Pe}$ & $9 \mathrm{~b}$ \\
\hline Krenosmittia hispanica Wüelker & * & $\mathrm{Im}, \mathrm{N}, \mathrm{Pe}$ & $8 a, 8 b$ \\
\hline Limnophyes bidumus Sæther & * & $\mathrm{Im}, \mathrm{N}, \mathrm{Pe}$ & $5 b, 8 a, 9,10$ \\
\hline Limnophyes gelasinus Sæther & * & $\mathrm{Im}, \mathrm{N}, \mathrm{Pe}$ & $9 b, 10$ \\
\hline Limnophyes spinigus Sæther & * & Im,Pe & $7 a, 8 a$ \\
\hline Orthocladius holsatus Goetghebuer & * & $\mathrm{Pe}$ & $7 \mathrm{~b}, 8 \mathrm{~b}$ \\
\hline Parachaetocladius sp.1 & ** & Im & $8 \mathrm{a}$ \\
\hline Parakiefferiella sp.1 & ** & $\mathrm{Im}, \mathrm{N}, \mathrm{Pe}$ & 9a \\
\hline Paralimnophyes longiseta Thienemann & $\mathrm{P}$ & $\mathrm{Im}, \mathrm{Pe}$ & 2,3,4b,5a \\
\hline Paraphaenocladius intercidens Brundin & * & $\mathrm{Pe}$ & $8 \mathrm{a}$ \\
\hline Paratrichocladius lanzavecchiae Rossaro & * & $\mathrm{Im}, \mathrm{N}, \mathrm{Pe}$ & $9 a, 9 b, 8 b, 10$ \\
\hline Paratrichocladius veronicae Rossaro & * & Im & $8 \mathrm{~b}, 9 \mathrm{~b}$ \\
\hline Pseudorthocladius sp.1 & ** & $\mathrm{Pe}$ & $8 \mathrm{a}, 8 \mathrm{~b}$ \\
\hline Pseudosmittia angusta (Edwards) & $\mathrm{P}$ & Im & 1a,1b,2,3a,5a \\
\hline Smittia aquatilis Goetghebuer & * & $\mathrm{Im}$ & $1 \mathrm{~b}, 2$ \\
\hline Smittia betuletorum Edwards & * & Im & 2 \\
\hline Smittia foliacea (Kieffer) & $\mathrm{P}$ & $\mathrm{Im}$ & 1a,2,3a,5,9,10 \\
\hline Smittia longitibia Goetghebuer & * & Im & $3 \mathrm{~b}, 6 \mathrm{~b}$ \\
\hline Smittia paranudipennis Brundin & * & Im & $7 a, 8 a$ \\
\hline Smittia reissi Rossaro \& Orendt & * & Im & $9 \mathrm{~b}$ \\
\hline Smittia scutellosaetosa Caspers & $\mathrm{P}$ & Im & $1,2,8 b, 9 b$ \\
\hline Smittia sp.1 & ** & Im & $1 b, 2$ \\
\hline Thienemannia libanica Laville \& Moubayed & $\mathrm{P}$ & $\mathrm{Pe}$ & $5 b, 10$ \\
\hline \multirow{2}{*}{\multicolumn{4}{|c|}{$\begin{array}{l}\text { Chironominae ( } 35 \text { species) } \\
\text { Chironomini (14 species) }\end{array}$}} \\
\hline & & & \\
\hline Chironomus sp.1 & ** & Im,N,Pe,L & $1 b, 2$ \\
\hline Cryptotendipes nigronitens (Edwards) & * & Im,N,Pe & $2,3 \mathrm{~b}, 9 \mathrm{a}$ \\
\hline Cryptotendipes usmaensis (Pagast) & $\mathrm{P}$ & $\mathrm{N}, \mathrm{Pe}$ & $1 b, 2,4 b, 9 b$ \\
\hline Dicrotendipes pallidicornis Goetghebuer & * & Im,Pe & $1 \mathrm{~b}, 2$ \\
\hline Glyptotendipes signatus Kieffer & $\mathrm{P}$ & $\mathrm{Im}, \mathrm{N}, \mathrm{Pe}$ & $1 b, 2,5 a$ \\
\hline Microchironomus deribae (Freeman) & $\mathrm{P}$ & $\mathrm{Im}, \mathrm{N}, \mathrm{Pe}$ & $1 b, 2,3$ \\
\hline Parachironomus digitalis Edwards & * & $\mathrm{Im}, \mathrm{N}, \mathrm{Pe}$ & $9 a, 9 b$ \\
\hline Parachironomus sp.1 & ** & $\mathrm{Im}, \mathrm{N}, \mathrm{Pe}, \mathrm{L}$ & $1 \mathrm{~b}, 2$ \\
\hline Polypedilum bicrenatum Kieffer & $\mathrm{P}$ & $\operatorname{Im}, \mathrm{N}, \mathrm{Pe}$ & 3a,3b,9b,10 \\
\hline Polypedilum tetracrenatum Hirvenoja & * & $\mathrm{Im}, \mathrm{N}, \mathrm{Pe}$ & $1 b, 2$ \\
\hline Polypedilum (Cerobregma) lotensis Moubayed-Breil & $\mathrm{P}$ & $\mathrm{Im}, \mathrm{N}, \mathrm{Pe}$ & 9a \\
\hline Polypedilum (C.) scetheri Moubayed-Breil & $\mathrm{P}$ & $\mathrm{Im}, \mathrm{N}, \mathrm{Pe}$ & $4 \mathrm{a}, 4 \mathrm{~b}, 9 \mathrm{a}$ \\
\hline Polypedilum (Tripodura) sp.1 & ** & $\mathrm{Pe}$ & $8 \mathrm{~b}, 9 \mathrm{~b}$ \\
\hline Sergentia coracina (Zetterstedt) & * & $\mathrm{Im}, \mathrm{Pe}$ & $1 \mathrm{~b}, 2,4 \mathrm{~b}, 9$ \\
\hline \multicolumn{4}{|l|}{ Tanytarsini ( 21 species) } \\
\hline Cladotanytarsus conversus Johannsen & $\mathrm{P}$ & Im,N,Pe,L & $1 \mathrm{~b}, 2$ \\
\hline Cladotanytarsus nigrovitattus Goetghebuer & $\mathrm{P}$ & $\mathrm{Im}, \mathrm{Pe}$ & $1 b, 2,8 a, 8 b$ \\
\hline Constempellina brevicosta (Edwards) & * & $\mathrm{Im}, \mathrm{N}, \mathrm{Pe}$ & $5 b, 9 a$ \\
\hline Constempellina sp.1 & ** & $\mathrm{Pe}$ & $1 \mathrm{~b}, 2$ \\
\hline Micropsectra aristata Pinder & * & $\mathrm{Im}, \mathrm{N}, \mathrm{Pe}$ & 1a,3a,3b,8b \\
\hline Micropsectra bavarica Stur \& Ekrem & * & $\mathrm{Im}, \mathrm{N}, \mathrm{Pe}$ & $4 a, 4 b, 5,8,9,10$ \\
\hline Micropsectra schrankelae Stur \& Ekrem & * & $\mathrm{Im}, \mathrm{N}, \mathrm{Pe}$ & $1,2,3,4,5 a, 8 b, 9,10$ \\
\hline Micropsectra sofiae Stur \& Ekrem & * & $\mathrm{Im}, \mathrm{N}, \mathrm{Pe}$ & $2,4,5 a, 8 a, 8 b, 9,10$ \\
\hline Micropsectra sp.1 & ** & $\mathrm{Im}, \mathrm{N}, \mathrm{Pe}, \mathrm{L}$ & $8 a$ \\
\hline Neozavrelia cuneipennis (Edwards) & * & Im,N,Pe & 1a,2,8a,9a \\
\hline Neozavrelia luteola Goetghebuer & * & Im,N,Pe & $9 a, 9 b$ \\
\hline
\end{tabular}




\begin{tabular}{lccc}
\hline \multicolumn{1}{c}{ List of species } & Record & Stage & Distribution \\
\hline Parapsectra uliginosa Reiss & $*$ & Im,N,Pe & $8 \mathrm{a}$ \\
Rheotanytarsus sp.1 & $* *$ & $\mathrm{Im}, \mathrm{N}, \mathrm{Pe}, \mathrm{L}$ & $8 \mathrm{a}, 8 \mathrm{~b}$ \\
Stempellina almi Brundin & $\mathrm{P}$ & $\mathrm{Im}, \mathrm{N}, \mathrm{Pe}, \mathrm{L}$ & $1 \mathrm{~b}, 2,5 \mathrm{~b}, 9 \mathrm{~b}, 10$ \\
Stempellina subglabripennis (Brundin) & $\mathrm{P}$ & $\mathrm{N}, \mathrm{Pe}$ & $9 \mathrm{a}, 9 \mathrm{~b}, 10$ \\
Stempellinella brevis (Edwards) & $\mathrm{P}$ & $\mathrm{Im}, \mathrm{N}, \mathrm{Pe}, \mathrm{L}$ & $2,3,4,5 \mathrm{a}, 8 \mathrm{~b}, 9,10$ \\
Stempellinella reissi Casas \& Vilchez-Quero & $\mathrm{P}$ & $\mathrm{Im}, \mathrm{N}, \mathrm{Pe}, \mathrm{L}$ & $8 \mathrm{a}, 8 \mathrm{~b}, 4 \mathrm{~b}, 9 \mathrm{a}$ \\
Tanytarsus longitarsis Kieffer, & $*$ & $\mathrm{~N}, \mathrm{Pe}$ & $1 \mathrm{~b}, 2$ \\
Tanytarsus multipunctatus Brundin & $*$ & $\mathrm{Im}, \mathrm{N}, \mathrm{Pe}$ & $1 \mathrm{~b}, 2$ \\
Virgatanytarsus sp.1 & $* *$ & $\mathrm{Pe}$ & $8 \mathrm{~b}, 9 \mathrm{a}, 9 \mathrm{~b}$ \\
Virgatanytarsus sp.2 & $* *$ & $\mathrm{Pe}$ & $1 \mathrm{~b}, 2$ \\
\hline
\end{tabular}

Laville 1991, Laville and Serra-Tosio 1996, Moubayed et al. 2000, Delettre 2001, Sæther and Spies 2004; Garcia and Laville 2000), 37 species are new records for France $(*)$ and 20 species belong to new undescribed species $(* *)$. The remaining species $(\mathrm{P})$ are considered to be new records for some regions or subregions of France. Thus, including the 37 new records which represent $5 \%$ of the French chironomid fauna, 718 chironomid species are now known from France. Of the 1237 European species listed in the last version of Fauna Europaea for Chironomidae by Sæther and Spies (2004), 58\% are recorded from France. In the current study, the highest diversity (37 and 34 species) was encountered in two areas located in southern France: south-central France (region 9, 45.6\%), eastern Pyrenees (subregion 8, 42\%).

\section{Distribution of some species and remarks}

- Procladius sp.1. Pupal material of Procladius sp.1 is collected in a high altitude lake in Eastern Pyrenees. It fits the description of Procladius sp reported from Norway by Fittkau and Murray (1985: 96, Fig. 5.31, C). This undescribed species can be easily recognized on the basis of the following thoracic horn characters: elliptic plastron; rim weakly represented, almost absent; respiratory atrium oval, elongated and larger at apex.

- Procladius crassinervis (Zetterstedt) was first reported by Serra-Tosio and Laville (1991) as a probable species from South Eastern France. The present record is based on mature male adults, pharates and pupal exuviae collected in lakes, ponds and large reservoirs located in northern areas at low altitude (1b, 2).

- Boreoheptagyia sp.1. Only one male adult was collected in a spring located in south eastern France (region 10). The species is morphologically similar to Boreoheptagyia rotunda Serra-Tosio but can be distinguished from this species by the following combination of characters: antenna $715 \mu \mathrm{m}$ long; $\mathrm{AR}=0.67$; last flagellomere $185 \mu \mathrm{m}$ long, elongated, longer than preceding 4 segments combined; presence of anal point on tergite IX; absence of notch on gonostylus.

- Diamesa thomasi Serra-Tosio. In France, $D$. thomasi has been recorded only from the two type localities located in the Central Pyrenees (7a, 4 adults) by Serra-Tosio (1970). I have found it in the Eastern Pyrenees (subregion 8a) where very large populations (adults, pharates, pupae and larvae) were collected, inhabiting high altitude peat pits located at $2250 \mathrm{~m}$; examples of associated species are $D$. aberrata Lundeberg, $D$. bohemani Goetghebuer, D. bertrami Edwards, $D$. veletensis Serra-Tosio, D. zernyi Edwards, Pseudodiamesa nivosa (Goetghebuer), $P$. branickii (Nowicki), Chaetocladius suecicus (Kieffer), Krenoposectra nohedensis Moubayed and Langton, Micropsectra auvergnensis Reiss.

- Cricotopus sp.1 is morphologically similar to C. levantinus Moubayed and Hirvenoja known from the lotic part of the Orontes River in Lebanon. Recently this species has been recorded from South-West Europe including France, Spain, Corsica (Fauna Europaea, Sæther and Spies 2004). Associated material including male adults, pharates, pupae and pupal exuviae of Cricotopus sp.1 was recently reported also from Algeria by Moubayed-Breil and Lounaci (2007) and shows that it belongs to a new species or new subspecies different from C. levantinus: the male imago lacks a notch on the gonocoxite lobe, the distribution of anterior armament on tergites III-VI of the pupal exuviae are not crescent-like and the size of spines on the pupal abdominal tergites are stronger in levantinus. Comparison of 
material from both Algeria and France with type material from Lebanon allowed us to consider that Cricotopus sp.1 from France, belongs to the same new species or subspecies as reported from Algeria. In addition, despite several lists of species reported from intense investigations in Syrian and Turkish territories along the extended basin of the Orontes River (Reiss 1985, 1986; Caspers and Reiss 1989) populations of $C$. levantinus are not recorded from these two neighboring countries.

- Eukiefferiella bedmari Vilchez-Quero \& Laville is reported as a circum-mediterrenean element well known from both AtlantoMediterranean (Spain, Morocco) and PontoMediterranean (Greece, Lebanon, Turkey) regions (Vilchez-Quero and Laville 1987; Laville and Reiss 1992). Eukiefferiella bedmari shows an unexpectedly large geographical distribution northward along both the South-West and Central-West Atlantic coastal streams (3a, 3b), and even reaches the Channel coastal streams (1a). However, despite thorough investigations in Southern France including Mediterranean coastal streams and rivers, this is the first record for this species in France. The material examined consists of a few pupal exuviae collected in some small Atlantic coastal rivers located in subregions $1 \mathrm{a}$, 3a and $3 \mathrm{~b}$.

- Limnophyes gelasinus Sæther has been known only from 1 single male adult from Korea (Sæther 1990). Here, L. gelasinus is for the first time recorded from the European continent (France), but it was also recently recorded from the North African region (Algeria) by Moubayed and Lounaci (2007). The material consists of a few male pharates and pupal exuviae, and the species seems to be well represented in south eastern France (region10) and the Aissi oued basin in Algeria.

- Paralimnophyes longiseta Thienemann has been exclusively encountered in both central and northern parts of Continental France (Serra-Tosio and Laville 1991, Delettre 2001). Male adults of $P$. longiseta, are rather well represented in wetland areas near marshes and ponds located eastward and westward of Central-France.

- Pseudosmittia angusta (Edwards), Smittia foliacea (Kieffer) and S. contingens (Walker) were first reported from France by Delettre (2001), but was overlooked in Fauna
Europaea. Only male imagines of $P$. angusta and $S$. foliacea were found in this study, and were collected along wetland and river basins in both the western and the eastern part of France: Atlantic and Channel coastal streams in the west (1a, 3a) and inland rivers in the east (5). In addition, only a few populations of $S$. foliacea are recorded from wetland areas located in the Mediterranean region (9a, 9b, 10).

- Micropsectra schrankelae Stur and Ekrem and $M$. sofiae Stur and Ekrem were recently described from Europe (Stur and Ekrem 2006). The identification of these two species in the male adult or pupal stage must be done with care as they are morphologically very similar to $M$. atrofasciata. I have recorded these two species from many regions throughout France, and will expect to see more records throughout the Holarctic region as the species' descriptions become more well known. Undoubtedly, many specimens previously believed to be $M$. atrofasciata probably are different species in the atrofasciata group and $M$. atrofasciata might be less widespread than it has been regarded in previous literature.

- $\quad$ Stempellinella reissi Casas \& Vilchez-Quero was until recently only known from its type locality in Sierra Nevada, Andalucia, Spain (Casas and Vilchez-Quero 1991). Material collected by me in the French Eastern Pyrenees was included in a recently published revision on Stempellinella (Ekrem 2007). Large populations of $S$. reissi have been captured from middle and high altitude springs and streams located in Eastern Pyrenees (8a) and Central France (region 4b). Larvae of $S$. reissi inhabit sandy and gravely habitats of cold waters near springs, peat pits and streams located at variable altitudes. Dense populations appear to be more common in streams located in high altitude areas.

\section{Acknowledgements}

Thanks are due to my colleague Torbjørn Ekrem (Trondheim, Norway) for helpful comments on the manuscript.

\section{References}

Casas, J. J. and Vilchez-Quero, A. 1991. Stempellinella reissi sp. n. (Diptera: 
Chironomidae) from Sierra Nevada (Southern Spain). Aquatic Insects, 13 (2): 115-121.

Caspers, N. and Reiss, F. 1989. Die Chironomidae der Turkei. Teil I: Podonominae, Diamesinae, Prodiamesinae, Orthocladiinae (Diptera, Nematocera, Chironomidae). Entomofauna, Zeitschrift Für Entomologie, 10 (8/1):105-160.

Delettre, Y. 2001. An annotated checklist of Chironomidae (Diptera) trapped in Brittany (France) since 1975. Annales de Limnologie, 37 (2) 143-149.

Ekrem, T. 2006. A redescription of Neozavrelia cuneipennis (Edwards) comb. nov., with a checklist of Neozavrelia species of the world (Diptera, Chironomidae). Zootaxa 1153: 116.

Ekrem, T. 2007. A taxonomic revision of the genus Stempellinella (Diptera, Chironomidae). Journal of Natural History, 41 (21-24): 13671465.

Fittkau, E. and Murray, D. A.1985. The pupae of Tanypodinae (Diptera: Chironomidae) of the Holarctic region-Keys and diagnoses. Entomologica Scandinavica, Supplement, 28: 31-113.

Garcia, X. F. and Laville, H. 2000. First inventory and faunistic particularities of the chironomid population from a $6^{\text {th }}$ order section of the sandy River Loire (France). Archiv für Hydrobiologie, 147 (4): 465-484.

Kyerematen, R. A. and Sæther, O. A. 2000. A review of Afrotropical Rheotanytarsus Thienemann et Bause, 1913 (Diptera: Chironomidae). Tijdschrift voor Entomologie 143: 27-69.

Langton, P. H. 1991. A key to pupal exuviae of the west Palaearctic Chironomidae. Privately published: Huntingdon, PE 17 1YH, England, 386 pp.

Langton, P. H. and Visser, H. 2003. Chironomidae exuviae. A key to pupal exuviae of the west Palaearctic region. Amsterdam: Biodiversity Center of ETI.

Laville, H. and Reiss, F. 1992. The Chironomid fauna of the Mediterranean region reviewed. Netherlands Journal of Aquatic Ecology, 26 (2-4): 239-245.

Laville, H. and Serra-Tosio, B. 1996. Additions et corrections à l'inventaire des Chironomidae (Diptera) de France depuis 1990. Annales de Limnologie, 32 (2): 115-121.
Michiels, S. and Spies, M. 2002. Description of Conchapelopia hittmairorum, spec. nov., and redefinition of similar western Palaearctic species (Insecta, Diptera, Chironomidae, Tanypodinae). Spixiana, 25 (3): 251-272.

Moubayed, J. and Hirvenoja, M. 1986. Les Chironomidae du Liban. IV. Cricotopus (Cricotopus) levantinus n. sp. (Diptera: Chironomidae, Orthocladiinae). Bulletin de la Société d'Histoires Naturelles de Toulouse, 122: 169-173.

Moubayed, J., Langton, P.H. and Morello, E. 2000. On some chironomid populations from permanent and temporary springs, streams and pools in France: distribution and biogeographical significance. In: Hoffrichter, O. (Ed.). Late $20^{\text {th }}$ century research on Chironomidae: an anthology from the $13^{\text {th }}$ International Symposium on Chironomidae. Shaker Verlag, Aachen: 571-577.

Moubayed-Breil, J. and Lounaci, A. 2007. New records of chironomids (Diptera) for the fauna of Algeria and North Africa. Ephemera, 8, in print.

Reiss, F. 1985. A contribution to the zoogeography of the Turkish Chironomidae (Diptera). Israel Journal of Entomology, 19: 161-170.

Reiss, F. 1986. Ein Beitrag zur Chironomidenfauna Syriens (Diptera, Chironomidae). Entomofauna, Zeitschrift Für Entomologie, 7 (11): 153-166.

Reiss, F. and Säwedal, L. 1981. Keys to males and pupae of the Palaearctic (Excl. Japan) Paratanytarsus Theinemann \& Bause, 1913, n. comb., with descriptions of three new species (Diptera: Chironomidae). Entomologica Scandinavica, Supplement, 15: 73-104.

Sæther, O.A. 1990. A review of the genus Limnophyes Eaton from the Holarctic and Afrotropical regions (Diptera: Chironomidae, Orthocladiinae). Entomologica scandinavica, Supplement, 35: 1-139.

Sæther, O. A. and Wang, X. 1995. Revision of the genus Paraphaenocladius Thienenemann, 1924 of the world (Diptera: Chironomidae, Orthocladiinae). Entomologica scandinavica, Supplement, 48: 3-69.

Sæther, O. A. and Ferrington, L. C. Jr. 2003. Nomenclature notes on some orthoclads (Diptera: Chironomidae). Zootaxa, 322:1-7.

Sæther, O. A. and Spies, M. 2004. Fauna 
Europaea: Chironomidae. In: de jong, M. (ed.) Fauna Europaea-Diptera: Nematocera, Fauna Europaea version 1.1.

Serra-Tosio, B. 1970. Les Diamesa du groupe damphi. Description d'une espèce nouvelle (Diptera, Chironomidae). Travaux $d u$ Laboratoire d'Hydrobiologie, Grenoble, 61 : 107-146.

Serra-Tosio, B. 1989. Révision des espèces ouestpaléarctiques et néarctiques de Boreoheptagyia Brundin avec des clés pour les larves, les nymphes et les imagos (Diptera, Chironomidae). Spixiana, 11 (2): 133-173.

Serra-Tosio, B. and Laville, H. 1991. Liste annotée des Diptères Chironomidés de France continentale et de Corse. Annales de Limnologie, 27 (1): 37-74.

Spies, M. and Sæther, O.A. 2004. Notes and recommendations on taxonomy and nomenclature of Chironomidae (Diptera). Zootaxa, 752: 1-90.
Stur, E. and Ekrem, T. 2006. A revision of West Palaearctic species of the Micropsectra atrofasciata species group (Diptera: Chironomidae). Zoological journal of the Linnean Society, 146: 165-225.

Soponis, A. R. 1990. A revision of the Holarctic species of Orthocladius (Euorthocladius) (Diptera: Chironomidae). Spixiana Supplement, 13: 1-68.

Tuiskunen, J. 1986. The Fennoscandian species of Parakiefferiella Thienemann (Diptera, Chironomidae, Orthocladiinae). ). Annales Zoologici Fennici, 23:175-196.

Vårdal, H. Bjørlo, A. and Sæther, O. A. 2002. Afrotropical Polypedilum subgenus Tripodura, with a review of the subgenus (Diptera: Chironomidae). Zoologica Scripta, 1 (4): 331-402.

Vilchez-Quero, A. and Laville, H. 1987. Eukiefferiella bedmari n. sp., nouvelle espèce à répartition méditerranéenne (Diptera, Chironoomidae). Annales de Limnologie, 23 (3): 209-215.

\section{SHORT COMMUNICATIONS}

\section{The Sublette Collection to University of Minnesota}

The Sublette Collection of Chironomidae has been given to the University of Minnesota, Department of Entomology, St.Paul/Minneapolis. Most of the collection has been transported back to the main campus by Len Ferrington and three graduate students. However, I have retained a skeleton reference collection, mostly of material from NM and CO, and hope to continue a modest research program. Prior to making the gift, a bulk of the Tanytarsini was loaned to Dr. Torbjørn Ekrem/Dr. Elisabeth Stur, Museum of Natural History and Archaeology, Norwegian University of Science and Technology, NO-7491 Trondheim, Norway, except the Cladotanytasus which were loaned to Dr. Wojciech Gilka, Department of Invertebrate Zoology, University of Gdansk, Al. Pilsudskiego 46, 81-378 Gdynia, Poland. Additionally, the Bryophaenocladius (Orthocladiinae) are on loan to Dr. Xinhua Wang, Life Science College, Nankai University, Tianjin, 300071 China. These loans will be returned to UMN. The collection contains extensive salivary gland squashes of polytene chromosomes, most with associated reared adults and immatures, from the genus Chironomus. These squash slides, most prepared by Mary Sublette, have the dissected larval head capsule and the terminal abdominal segments mounted on the same slide.

James E. Sublette 


\section{New Chironomidae Mailing List}

Cardiff University has generously run the chironomid listserver for about 10 years now. David Pascoe, who has done a wonderful job in administrating it since 2000, recently decided that it was time to pass this task on to someone else. The Museum of Natural History and Archaeology gladly accepted to take on the job, and I will try to keep the list up and running. Members of the old mailing list have automatically become subscribers of the new one, and should already have received a welcome message. If you have not become one, you are not yet registered as a subscriber, and can do so at this web page: http://lists.vm.ntnu.no/mailman/listinfo/chironomidae. From this site you can also administer your subscription and view the mailinglist archive. To post a message to subscribers of the mailinglist, write an email to Chironomidae@lists.vm.ntnu.no. I look forward to see fruitful discussions and good flow of information in the new Chironomidae listserver!

\section{Torbjørn Ekrem}

\section{New Books}

\section{“Contributions to the Systematics and Ecology of Aquatic Diptera: A Tribute to Ole A. Scether"}

Edited by Trond Andersen

In order to congratulate Ole A. Sæther on his 70th birthday and for 46 prosperous years of scientific studies in freshwater biology and insect systematics, colleagues from around the world contributed 35 papers on the ecology and systematics of Ceratopogonidae, Chaoboridae, Chironomidae, and Psychodidae. Eight new genera and nearly 50 new species are described in this book which comprises more than 350 pages. All articles were peer-reviewed before publication.

\section{Content}

Ekrem, T. and T. Andersen: Professor Ole Anton Sæther 70 years: four

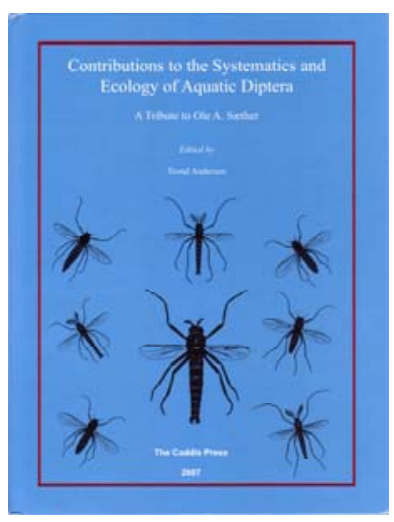
decades of chironomid research.

Andersen, T. and H. F. Mendes: Five enigmatic new orthoclad genera from Brazil (Diptera: Chironomidae, Orthocladiinae).

Ashe, P. and J. P. O’Connor: A new genus and species of Orthocladiinae (Diptera: Chironomidae) from Sulawesi, Indonesia.

Brodersen, K. P.: Chironomids (Diptera) from sub-saline lakes in West Greenland: diversity, assemblage structure and respiratory adaptation.

Caldwell, B. A.: Morphological variation, additional distribution records, and notes on ecology of Pagastia orthogonia Oliver (Diptera: Chironomidae).

Cranston, P. S., G. M. Benigno and M. C. Dominguez: Hydrobaenus saetheri Cranston, new species, an aestivating, winter-emerging chironomid (Diptera: Chironomidae) from California.

Ekrem, T. and G. A. Halvorsen: Taxonomy of Tanytarsus lapponicus Lindeberg, 1970, a species with larval mandible of 'lugens-type’ (Diptera: Chironomidae).

Ekrem, T. and E. Stur: Description of Tanytarsus hjulorum, new species, with notes and DNA barcodes of some South African Tanytarsus (Diptera: Chironomidae).

Endo, K., E. A. Makarchenko and E. Willassen: On the systematics of Linevitshia Makarchenko, 1987 (Diptera: Chironomidae, Diamesinae), with the description of L. yezoensis Endo, new species.

Ferrington, L. C. Jr.: Hibernal emergence patterns of Chironomidae in lotic habitats of Kansas versus substrate composition.

Giłka, W. and L. Paasivirta: Two new species of the genus Tanytarsus van der Wulp (Diptera: Chironomidae) from Fennoscandia.

Goddeeris, B., K. Hermans and H. Hampel: Experimental termination of diapause in three Chaoborus species (Diptera: Chaoboridae) from a Belgian lowland pond. 
Hirabayashi, K., G. Kimura, Y. Fukunaga and M. Yamamoto: Distribution pattern of chironomid midges (Diptera: Chironomidae) in the upper and middle reaches of the Shinano River in Central Japan.

Jacobsen, R. E.: Orthocladius (Orthocladius) saetheri new species, from the Appalachian Mountains (Diptera: Chironomidae).

Jacobsen, R. E. and B. Bilyj: An unusual new Cladotanytarsus from oligotrophic Florida Everglades marshes (Diptera: Chironomidae).

Kobayash i, T., R. Nakazato and M. Higo: The identity of Japanese Lipiniella Shilova species (Diptera: Chironomidae).

Lencioni, V., B. Rossaro and B. Maiolini: Alpine chironomid distribution: a mere question of altitude?

Makarchenko, E. A. and M. A. Makarchenko: A review of Tokunagaia Sæther (Diptera: Chironomidae) from the Russian Far East, with the description of four new species.

Martin, J., A. Blinov, E. Alieva and K. Hirabayashi: A molecular phylogenetic investigation of the genera closely related to Chironomus Meigen (Diptera: Chironomidae).

Moubayed-Breil, J.: Polypedilum (Cerobregma) lotensis new species, and P. (C.) saetheri new species, from lowland streams and rivers in France (Diptera: Chironomidae).

Murray, D. A.: Limnophyes platystylus new species (Diptera: Chironomidae, Orthocladiinae) from Ireland.

Niitsuma, H.: Saetheromyia, a new genus of Tanypodinae from Japan (Diptera: Chironomidae).

Oyewo, E. A. and R. E. Jacobsen: Polypedilum (Pentapedilum) epleri, a new species from the eastern USA (Diptera: Chironomidae).

Paasivirta, L.: Chironomid species in Finnish springs and their surroundings.

Paggi, A. C.: A new Neotropical species of the genus Thienemanniella Kieffer, 1911 (Diptera: Chironomidae, Orthocladiinae).

Roque, F. O. and S. Trivinho-Strixino: Spatial distribution of chironomid larvae in low-order streams in southeastern Brazilian Atlantic Forest, a multiple scale approach.

Sanseverino, A. M. and E. J. Fittkau: Taxonomy of Caladomyia alata (Paggi, 1992) comb. n. and Caladomyia tuberculata (Reiss, 1972) comb. n. (Diptera: Chironomidae).

Szadziewski, R., W. Giłka and P. Dominiak: A redescription of Forcipomyia squamigera Kieffer, 1916 in all stages (Diptera: Ceratopogonidae).

Trivinho-Strixino, S. and T. Siqueira: New species of Beardius Reiss and Sublette, 1985 (Diptera: Chironomidae) from Southeastern Brazil.

Wagner, R. and T. Andersen: Psychodidae (Diptera: Nematocera) from the West Usambara Mountains, Tanzania.

Wang, X., Y. Liu and L. Paasivirta: A new species of Propsilocerus Kieffer from Finland (Diptera: Chironomidae, Orthocladiinae).

Willassen, E.: Sasayusurika aenigmata Makarchenko (Diptera: Chironomidae, Diamesinae) - a Japanese endemic discovered in the Indian Himalaya.

Wülker, W. F.: Two new Chironomus species with fluviatilis-type larvae from the near-shore sandy sediments of Lake Michigan (Diptera: Chironomidae).

Yamamoto, M., K. Hirabayashi and M. Matsuzawa: The Korean species Hanochironomus tumerestylus Ree, 1992 taken on Ishigaki Island, Japan (Diptera: Chironomidae).

Zorina, O. V.: Olecryptotendipes, a new genus in the Harnischia complex (Diptera: Chironomidae) from the Russian Far East.

Trond Andersen

Book reference

Andersen, Trond (editor). 2007. Contributions to the Systematics and Ecology of Aquatic Diptera: A

Tribute to Ole A. Sæether. The Caddis Press. Columbus, Ohio. vi + 358 pp. ISBN 0-9667982-3-6

How to order

Order from:

Price:

The Caddis Press, P.O. Box 21039, Columbus, OH 43221-0039 USA

Payment: $\quad$ PayPal (using < barmitag@columbus.rr.com>), International Postal Money Order, or a personal check drawn on a US bank in US dollars. Purchase orders from verified institutions will be accepted, but subsequent payment must be by one of these three methods.

Postage: $\quad$ United States: Media Mail (\$5), Priority Mail (\$9)

Canada and Mexico: Priority Mail International (6-10 days- \$20 US) 


\section{New Key to Chironomidae adult males}

It is finally here - a new edition of the probably most widely used key to species-level identification of chironomid adult males.

The 1978 key by Clive Pinder has been out of print for some time, but instead of merely reprinting the old version, Peter Langton and Clive Pinder have done a marvellous job in adding species and update the taxonomy and nomenclature. In fact, the number of included species is increased by $35 \%$ in the 2007 edition. Thus, it will most certainly be a welcomed addition to the library of many chiromidologists, not only in Great Britain. This is hardly the only reason why the books are worth buying though. The introduction includes facts and details on Chironomidae morphology, taxonomy, phylogeny and methodology, and will therefore be an excellent starting point for students and other beginners in midge identification. The only key references I was missing in this part of the publication was Sæther's most recent works on nematoceran and chironomid phylogenies (Sæther 2000a, b) and the significant nomenclatorial remarks by Spies and Sæther (2004).

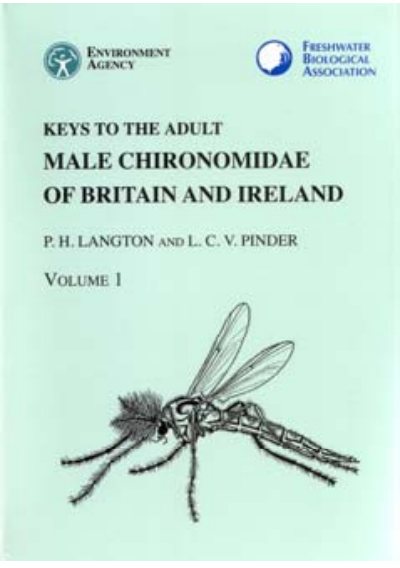

Like the 1978 edition, the separate keys subfamilies, genera and species are enriched with drawings of diagnostic characters directly in the text. This is particularly useful as you do not need to search for the clarifying drawing in a plate at the end or in a different volume. Still, Langton and Pinder have chosen to keep the volume with hypopygial drawings for additional identification confirmation, a very wise decision in my opinion. The drawings are of good quality artistically, but I was somewhat disappointed to see that the print was poorer than the 1978 edition despite that the paper used is of better quality. Although, perhaps not always necessary to display diagnostic features properly, those of us who appreciate fine details will be less satisfied with the plates now than we were for the 1978 edition. I also think that plates numbered with letters are easier to navigate in than unnumbered figures, although the pattern repeats itself and is properly explained in the beginning of volume 2 .

The publication of this key has been delayed for some time after the manuscript was finalised, and the reader should be aware that there are publications on chironomid taxonomy and nomenclature from 20062007 that are not allowed for (e.g. Stur and Ekrem 2006), and some inconsistencies in name use with that recommended by Spies and Sæther (2004). Moreover, a key supplement diagnosing 16 additional species was added to volume two at a later stage and is therefore not incorporated directly in the major key but in the end of volume 2. This could have been problematic, but the authors have made sure that the supplement is referred to in the major key whenever this is relevant. Thus, although not optimal, I think their solution is considerably better than leaving out the additional 16 species all together. The index at the end of volume 1 is also worth commenting on since it is organised by genus and works as a checklist as well as an index to all treated species. It is easy to navigate in and directs the reader both to the relevant key and the hypopygium drawing.

In general, the new key by Langton and Pinder is well written, taxonomically comprehensive and will be an extremely valuable tool for European chironomid species identification in the future. If you haven't ordered it yet, you should.

Torbjørn Ekrem, Torbjorn.Ekrem@vm.ntnu.no

Book reference

Langton, P.H. \& Pinder, L.C.V. 2007. Keys to the adult male Chironomidae of Britain and Ireland. Vols 1 \& 2. Freshwater Biological Association, Scientific Publication 64, pp. $239+168$. ISBN 0-900386-75-6 
References

Pinder L. C. V. 1978. A key to the adult males of the British Chironomidae (Diptera). Vol. 1 \& 2. Freshwater Biological Association Scientific Publication. 78, 169 p.

Spies M., Sæther O. A. 2004. Notes and recommendations on taxonomy and nomenclature of Chironomidae (Diptera). - Zootaxa 752: 3-90.

Stur E., Ekrem T. 2006. A revision of West Palaearctic species of the Micropsectra atrofasciata species group (Diptera: Chironomidae). - Zoological Journal of the Linnean Society 146: 162-225.

Sæther O. A. 2000a. Phylogeny of Culicomorpha (Diptera). - Systematic Entomology 25: 223-234.

Sæther O. A. 2000b. Phylogeny of the subfamilies of Chironomidae (Diptera). - Systematic Entomology 25: 393-403.

How to order

Order from:

The Freshwater Biological Association, The Ferry Landing, Far Sawrey, Ambleside, Cumbria, LA22 OLP, U.K. Email: info@fba.org.uk. Internet:

www.fba.org.uk/fbapub.html

Price: $£ 50$ for both volumes + postage \& packing.

\section{New key to Tanypodinae larvae}

The Chironomidae Larvae of the Netherlands and Adjacent Lowlands is the first volume of a new series of practical keys to chironomid larvae. Its subtitle General ecology and Tanypodinae describes what authors Henk Vallenduuk and Henk Moller Pillot have found room for in the almost 150 pages of this volume.

The first part of the book is devoted to a chapter on general ecology of Chironomidae and includes facts on behaviour, life history and responses to abiotic environmental factors. It is quite interesting reading and gives a nice, compact view of the most important areas of chironomid ecology. The remaining part of the book is dedicated to keys, descriptions, ecological notes and numerous figures of Tanypodinae larvae. The major key is made for both third and fourth instar larvae, is mostly dichotomous, and is accompanied by line drawings of characteristic features. It includes 56 taxa and is so constructed that most of the characters used can be observed using a decent stereo microscope, facilitating rapid identification without the need for slide preparations. Although clearly an advantage for ecologists, it takes some practice to get used to. The larval key is followed by a "key to prepupa". This pictorial guide to genera and species using thoracic horns is a very useful addition to the larval key and is certainly a valuable tool to identify prepupa. The fact that this key is not dichotomous is not disturbing since the seven pages of drawings and key features are easy to navigate. The remaining part of chapter five includes morphological comments, identification

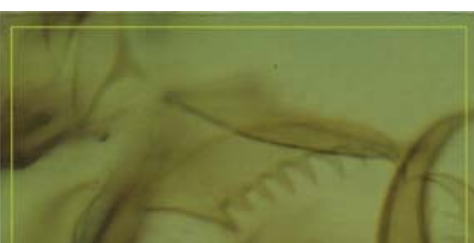
Chironomidae Larvae General ecology and Tanypodinae

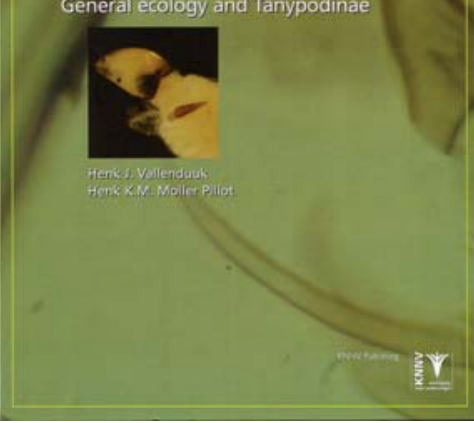
matrices and more illuminating drawings. Although the authors clearly state that the book does not include complete descriptions of the larva, and perhaps best is viewed as a supplement to existing taxonomical literature, key characters are treated both in keys, taxonomic comments and matrices. Moreover, chapter six treats each and every taxonomical entity included in the keys (either species of genus) in detail with comments on systematics, distribution and numerous ecological aspects. This part of the book is very well referenced and a good source for additional literature on the Tanypodinae. Even reports and theses are cited. There is, however, at least one major work that remains unmentioned. Fauna Europaea (Sæther \& Spies 2004) has become one of the major references for taxonomical and distributional data on European Chironomidae, and it would be useful for the reader to know how the Fauna Europaea data relate to the information given in the book. Also, I think the book would have benefited from and found a broader audience if all European genera were included in the key. As an example, the genus Larsia is not uncommon in Europe, and has among other countries also been found in Belgium, France, Luxembourg and Germany. The key in Chironomidae Larvae of the Netherlands and Adjacent Lowlands does not include Larsia and chances are high that sampled Larsia larvae will be identified to morphologically similar genera (and thus remain undetected) if this book is the only tool 
used for identification. There are only five European genera which are not treated in the book (Pentaneurella, Larsia, Derotanypus, Hayesomyia, Meropelopia), thus reference to these could easily have been included. The final pages of the book contain numerous diagnostic microphotographs and tables of biological and ecological properties of Tanypodinae larvae.

In general, the Chironomidae Larvae of the Netherlands and Adjacent Lowlands should be useful to all chironomid ecologists and palaeolimnologists, and also to most taxonomists working with tanypodines. However, due to the geographical limitation, the book might be best suited for those working in the Netherlands. The price of EUR 69.50 for the nicely bound hardcover book is in the higher end of the scale, and will perhaps make many potential buyers think twice before ordering - especially if working outside of the European Lowlands.

Elisabeth Stur, Elisabeth.Stur@vm.ntnu.no

Book reference

Vallenduuk, H.J, Moller Pillot, H.K.M. 2007. Chironomidae larvae of the Netherlands and adjacent lowlands - General ecology and the Tanypodinae. KNNV Pubilshing, Zeist, the Netherlands, pp. 144. ISBN 978-90-5011-259-8.

\section{References}

Sæther O.A. Spies M., 2004. Chironomidae. In de Jong, XX (ed) Fauna Europaea v 1.2. www.faunaeur.org.

How to order

Order from:

KNNV Publishing, PO Box 310, 3700 AH Zeist, The Netherlands. Fax: +31 30 2368907. Email: info@knnvuitgeverij.nl.

Price: EUR 69.50 .

\section{The identification and use of Palaearctic Chironomidae larvae in palaeoecology}

The guide describes and illustrates 198 sub-fossil chironomid types and categories that can be found in European lake sediments and includes ca. 280 colour photographs of fossil chironomid specimens. Furthermore, it contains an introduction to chironomid palaeoecology, chironomid ecology, and preparation methods for sub-fossil chironomid remains.

This is a practical guide for both the skilled and the novice researcher on sub-fossil chironomids. The book contains adequate background information to get started from scratch. The first chapters include a brief review on practical laboratory- and field techniques, the life history of chironomids, the use of chironomids as proxies of past environmental conditions, identification of subfossil head capsules, and importantly for the palaeoecologist, on the influence of key environmental variables on chironomids. In the latter section, the authors discuss the influence of temperature, $\mathrm{pH}$, substrate morphology, water depth, food, and salinity. The only relevant information on chironomids that I feel deserves more mentioning in the introductory chapters is a section on species interactions, such as competition and predation. It may be hard to quantify the impact of species interaction on any palaeoenvironmental inference based on chironomids, however predation and competition certainly exert some influence on the species community structure, and hence may also influence any

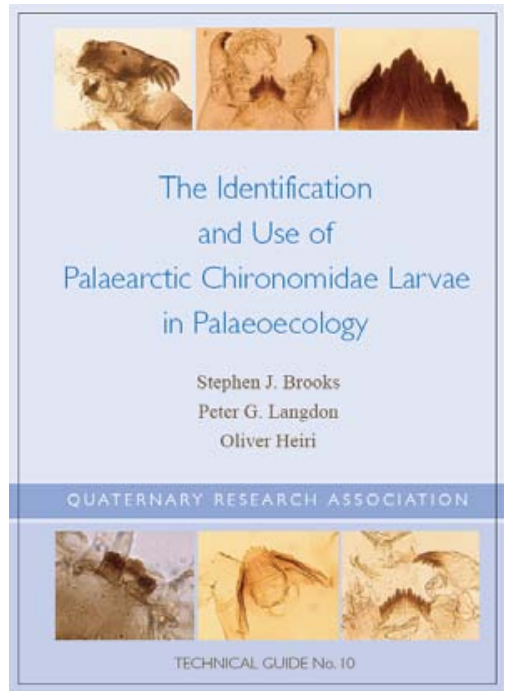
inference. 
In the introduction, I especially appreciate that the authors also discuss some weaknesses that must be borne in mind during interpretation of chironomid data. These shortcomings include the taxonomy of subfossil head capsules, but in this respect, the taxonomic contribution in this book is a milestone. This manual is by far the most up to date and elaborate identification guide on sub-fossil chironomid head capsules that exists. The taxonomic keys and images compose the main body of the book. All genera include a diagnostic section of the genus and of head capsule morphotypes within the genus. In addition, information on how to separate morphological similar taxa is given and the authors have amalgamated information on the environmental preferences of the taxa. The taxonomic knowledge presented in the book is the culmination of years of experience among the authors and among leading scientists sharing information at international workshops.

Many of the images provided are composed of multi layered stacked digital pictures. The quality of the images is generally high and the specimens reflect the wide array of preservation status for sub-fossil head capsules. Most researchers will find themselves flipping the pages and comparing the particular specimen in the microscope against the images provided in the book. In the foreword, Ian Walker fittingly remarks that, "The authors' greatest reward will find this book not on library shelves, but lying next to the microscope, among an active midden of microscope slides.” While many researchers on sub-fossil head capsules up to now have been flipping through worn copies of Wiederholm's (1983) manual on chironomids of the Holarctic region, I am certain most of us will replace Wiederholm by Brooks et al. This is not to say that the book is the final contribution to sub-fossil chironomid analysis. We should seek for higher taxonomic resolution and correct neotaxonomical nomenclature. For sub-fossil head capsules with worn or lacking critical characters, the outcome of the identification can rarely be confident at species level. However, the taxonomy for many groups in the manual approaches that of neotaxonomy apart from the use of types, i.e. Endochironomis tendens - type, or Cladotanytarsus mancus types 1 and 2. For other groups, the taxonomic resolution may still be refined as we search the wealth of already existing information and information in progress on reared and DNA-barcoded larval specimens. This is important in order to close the gap between researchers working on past and on present chironomids. The key to understanding past chironomid assemblages lies in the present. There is room for many future editions of this book with refined taxonomy and ecological information. In these editions to come, I have one plead; please provide larger images! Squeezing figure captions and six images, many of which contain minute details, on one A5 sized page does not make sense in a practical laboratory manual meant for countless hours of picture-surfing. One gets a good general introduction into sub-fossil chironomid analysis by reading the first three chapters. However, such methodological literature already exists. If space was limiting when the book was produced, I would rather have the introductory sections shortened and spent more space on larger images. Most of us will perhaps only read the introductory chapters once, while the rest will be explored on a daily basis. Still, this manual is a must-have for all researchers even minutely involved with sub-fossil chironomid analysis.

Gaute Velle, Gaute.Velle@bio.uib.no

Book reference

Brooks, S.J., P.G. Langdon, O. Heiri (2007). The identification and use of Palaearctic Chironomidae larvae in palaeoecology, Quaternary Research Association Technical Guide 10, 276 pp. ISBN: 0907 780717.

How to order

Order from: The Quaternary Research Association. See: http://qra.org.uk/publications.htm

Price: $\quad £ 20.00+$ postage \& packing. 
REGIONAL REPRESENTATIVES 2007

\section{AfRICA}

Amakye, Josef S., Institute of Aquatic Biology (C.S.I.R.), P.O.Box 38, Achimota -Accra, Ghana. Regional representative for West Africa

Harrison, Arthur, 8 - 7847 East Saanich Road, Saanichton, B.C. V8M 2B4, Canada. Email: harrisona@shaw.ca Regional representative for South Africa

\author{
AMERICAS \\ Masaferro, Julieta, Department of Entomology, \\ Natural History Museum, Cromwell Road, \\ London SW7 5BD, U.K. Email: \\ J.Massaferro@nhm.ac.uk Regional \\ representative for Argentina
}

Callisto, Marcos, Universidade Federal de Minas Gerais, ICB, Depto. Biologia Geral, Lab. Limnologia/Ecologia de Bentos, CP. 486, CEP. 30.161-970, Belo Horizonte, MG, Brazil. Email: callisto@mono.icb.ufmg.br Regional representative for Brazil

Walker, Ian R., Biology and Earth \& Environmental Sciences, University of British Columbia Okanagan, 3333 University Way, Kelowna, British Columbia, Canada V1V 1V7 Email: ian.walker@ubc.ca Regional representative for Canada

De la Rosa, Carlos, Catalina Island Conservancy, P. O. Box 2739, Avalon, California 90704, USA. Email: cdelarosa@catalinaconservancy.org Regional representative for Central America

Alcocer, Javier, UNAM Campus Iztacala, Limnology Lab, Environmental Conservation \& Improvement Project, Universidad Nacional Autonoma de Mexico, Calle 15, \#51 San Pedro de los Pinos, Mexico City, D.F. 03800, Mexico. Email: jalcocer@unamvm1.dgsca.unam.mx Regional representative for Mexico

Burgos, Arnoldine, Bureau voor Openbare Gezondheidszorg, Centraal laboratorium, Rode Kruislaan 13 Postbus 1911, Paramaribo, Suriname. Regional representative for Suriname
Ferrington Jr., L.C., Department of Entomology, Hodson Hall, 1980 Folwell Avenue, University of Minnesota, St. Paul, MN 55108, USA. Email: ferri016@tc.umn.edu Regional representative for USA

AsIA

Wang, Xinhua, Department of Biology, Nankai University, Tianjin, 300071 China. Email: xhwang@nankai.edu.cn Regional representative for the P. R. of China

Mazumdar, Abhijit, Dept of Zoology, University of Burdwan, Burdwan 713 104, W.B., India Email: abhijitau@rediffmail.com Regional representative for India

Mousayi, Seyed Karim, University of Tromsø, Institute of Clinical Medicine (IKM), KK Lab, Brevika Centre, N-9037 Tromsø, Norway. Email: karimm@fagmed.uit.no Regional representative for Iran

Kugler, Jehoshua, Dept of Zoology, Tel-Aviv University, Tel-Aviv 69978, Israel. Regional representative for Israel

Iwakuma, Toshio, Hokkaido University, KitaJujo-Nishi 5, Kita-ku, Sapporo, Hokkaido, 060 Japan. Email: iwakuma@ees.hokudai.ac.jp Regional representative for Japan

Ismail, A.R., Jabatan Biologie, University Pertanian Malaysia, 43400 UPM Serdang, Selangor, Malaysia. Regional representative for Malaysia

Makarchenko, Eugenyi A., Laboratory of Freshwater Hydrobiology, Institute of Biology and Soil Sciences, Far Eastern Branch of the Russian Academy of Sciences, 690022 Vladivostok - 22, Russia. Email: emakarchenko@mail.ru Regional representative for the Far East of Russia

Erbaeva, Engelsina, Institute of Biology, Irkutsk State University, P.O. Box 24, Lenin street 3, 664033 Irkutsk, Russia. Regional representative for Lake Baikal and River Angara, South Siberia 
Byeong-Jin, Youn, Pusan National University, Department of Biology, \#30 Changjeon-dong Kumjeong-Ku, Pusan 609- 735, South Korea. Regional representative for South Korea

\section{EUROPE}

Contreras, Ruth, Naturhistorisches Museum, 2. Zoologische Abt., Burgring 7 (Box 417), A-1014 Wien, Austria. Email: ruth.contreras@wavenet.at Regional representative for Austria

Goddeeris, Boudewijn, Koninklijk Belgisch Instituut voor Natuurwetenschappen, Afdeling Zoetwaterbiologie, Vautierstraat 29, B-1040 Brussels, Belgium. Email: goddeeri@kbinirsnb.be Regional representative for Belgium

Michailova, Paraskeva, Institute ofZoology, boul. Rouski 1, Bulgarian Academy of Sciences, Institute of Zoology, Sofia 1000, Bulgaria. Email: parmich@mail.bol.bg Regional representative for Bulgaria

Matena, Josef , Biology Centre, Academy of Sciences CR, Institute of Hydrobiology, Na Sadkach 7, CZ-370 05 Ceske Budejovice, Czech Republic. Email: matena@hbu.cas.cz Regional representative for Czech Republic

Lindegaard, Claus, Freshwater Biological Laboratory, University of Copenhagen, 51 Helsingorsgade, DK-3400, Hillerød, Denmark. Email: clindegaard@bi.ku.dk Regional representative for Denmark

Kangur, Andu \& Kulli, Vorstjarv Limnological station, EE2454 Rannu, Estonia. Email: andu@lim.tartu.ee Regional representative for Estonia

Koskenniemi, Esa, West Finland Regional Environment Centre, P.O. Box 262, FIN-65101 Vaasa, Finland. Email:

Esa.Koskenniemi@environment.fi Regional representative for Finland

Delettre, Yannick R., C.N.R.S. (U.M.R. 6553 "ECOBIO") - Universite de Rennes I, Station Biologique, F-35380 Paimpont, France. Email: yannick.Delettre@univ-rennes1.fr Regional representative for France

Spies, Martin, Schraemelstr. 151, D-81247

München, Germany. Email:

spies@zi.biologie.uni-muenchen.de Regional representative for Germany
Dévai, György, L. Kossuth University, Ecological Institute, H-4010 Debrecen, Hungary. Email: devaigy@delfin.klte.hu Regional representative for Hungary

Olafsson, Jon S., Institute of Freshwater Fisheries, Keldnaholt, IS-112 Reykjavik, Iceland. E-mail: jsol@veidimal.is Regional representative for Iceland

Murray, Declan, UCD School of Biology and Environmental Science, Science Education and Research Centre (West), University College Dublin, Belfield, Dublin 4, Ireland . Email: declan.murray@ucd.ie Regional representative for Ireland

Rossaro, Bruno, Univ. of Milano, Dept. of Biology, Sect. Ecology, via Celoria 26, I-20133 Milano, Italy. Email: rossaro@mailserver.unimi.it Regional representative for ltaly

Leslie, Heather A., Institute for Environmental Studies (IVM), Vrije Universiteit, De Boelelaan 1085, 1081 HV Amsterdam, The Netherlands. Email: heather.leslie@ivm.falw.vu.nl Regional representative for the Netherlands

Willassen, Endre, University of Bergen, Bergen Museum, The Natural History Collections, Muséplass 3, NO-5007 Bergen, Norway. Email: Endre.Willassen@zmb.uib.no Regional representative for Norway

Kownacki, Andrzei, Institute of Freshwater Biology, Academy of Sciences, Ul. Slawkowska 17, PL-31016 Krakow, Poland. Regional representative for Poland

Hughes, Samantha, Instituto Superior de Agronomia, Universidade Técnica de Lisboa, Departamento de Engenharia Florestal (DEF), Tapada da Ajuda, 1349-017 Lisboa, Portugal. E-mail: sammyno1@isa.utl.pt or Centro de Estudos da Macaronésia (CEM), Universidade da Madeira, Campus da Penteada, 9000-390 Funchal, Madeira, Portugal. E-mail: samantha@uma.pt Regional representative for Portugal

Tudorancea, Maria-Monica, Department of Ecology-Genetics, Faculty of Biology and Geology, "Babes-Bolyai" University, $1 \mathrm{M}$. Kogalniceanu Str., Cluj-Napoca, 3400 Romania. Email: mtudor@biolog.ubbcluj.ro Regional representative for Romania

Zinchenco, Tatiana, Institute of Ecology of the Volga River Bassin, Russian Academy of Sciences, Togliatti 445003, Russia. Email: tdz@mailru.com Regional representative for European Russia and the Volga Region 
Bitusik, Peter, Faculty of Ecology and Environmental Sciences, Technical University, Kolpasska 9, SK-969 01 Banska Stiavnica, Slovakia. Email: bitusik@fee.tuzvo.sk Regional representative for Slovakia

Rieradevall, Maria, Departament d'Ecologia, Facultat de Biologia, Universitat de Barcelona, Diagonal 645 - 08028 Barcelona, Spain. Email: mrieradevall@ub.edu Regional representative for Spain

Johnson, Richard K., University of Agricultural Sciences, Box 7050, S 75007 Uppsala, Sweden. Email: Richard.Johnson@ma.slu.se Regional representative for Sweden

Lods-Crozet, Brigitte, Service des Eaux, Sols et Assainissement, Chemin des Boveresses 155, CH-1066 Epalinges, Switzerland. Email: brigitte.lodscrozet@sesa.vd.ch Regional representative for Switzerland

Langton, Peter H., 5 Kylebeg Avenue, Mountsandel, Coleraine, Co. Londonderry, Northern Ireland, BT52 1JN - Northern Ireland. Email: PHLangton@kylebegave.fsnet.co.uk Regional representative for UK

\section{PACIFIC}

Cranston, Peter S., Department of Entomology, University of California, One Shields Avenue, Davis, CA 95616, US. Email:

pscranston@ucdavis.edu Regional

representative for Australia

Boothroyd, Ian K.G., Kingett Mitchell \& Associates, Level 2, ASDA Plaza, 4 Fred Thomas Drive, P.O. Box 33849, Takapuna, Auckland, New Zealand Email: iboothroyd@kma.co.nz (work) Regional representative for New Zealand

Catalan, Zenaida Batac, Institute of Environmental Science and Management, The University of the Philippines at Los Banos, College, Laguna, Philippines. Regional representative for Philippines 


\title{
CURRENT BIBLIOGRAPHY
}

\section{CURRENT BIBLIOGRAPHY: 1 JAN. 2006 - 30 SEP. 2007}

\author{
Odwin Hoffrichter \\ Institut für Biologie I, Albert-Ludwigs-Universität Freiburg, Hauptstrasse 1, D-79104, Germany \\ Email: odwin.hoffrichter@biologie.uni-freiburg.de
}

This listing is different from what has been presented in earlier issues: In order to justify the epithet "current", and due to the fact that nearly 300 titles for 2007 are already saved, all of the most actual titles hitherto collected are listed, preceded by the - hopefully almost complete - year 2006 and by supplements to the two preceding years. The compilation was achieved, as usual, from many sources: databases, tables of contents of journals, references and citations of papers, autopsy of many periodicals, lists provided by authors (thanks to you!). In particular, publisher issued search alerts proved to be rich in results. Only printed titles are reported here with the occasional exception of online-only journals (PLoS or BioMed journals e.g.). Titles announced, even with available DOI numbers, are not considered before printing. In general, online publications should be retrieved elsewhere, best check the chironomid home page for eventual references regularly.

\section{Supplement to 2004 Current Bibliography}

Bachmann, J. 2004a. Community analysis of Chironomidae (Diptera) from stream and shoreline habitats of Lake Hovsgol, Mongolia. - Sen. Res. Thes., Wayne St. Coll., Wayne.

Bal k, S., Ustaoğlu, M. R., Özbek, M., Taşdemir, A. ve Y ld z, S. 2004a. Buldan Baraj Gölü'nün (Denizli, Türkiye)) bentik faunas . (Benthic fauna of Buldan Reservoir (Denizli, Turkey).) - Su Ürünleri Derg. 21: 139-141.

Barley, E. M. 2004a. Paleoclimate analysis of southwestern Yukon Territory using subfossil chironomid remains from Antifreeze Pond. M. Sc. Thes., Simon Fraser Univ., Burnaby.

Bennike, O., Brodersen, K. P., Jeppesen, E. and Walker, I. R. 2004a. Aquatic invertebrates and high latitude paleolimnology. - In: Pienitz, R., Douglas, M. S. V. and Smol, J. P. (eds): Longterm environmental change in Arctic and Antarctic lakes, pp. 159-186. Kluwer Acad. Publs., Dordrecht.

Bentivegna, C. S., Alfano, J.-E., Bugel, S. M. and Czechowicz, K. 2004a. Influence of sediment characteristics on heavy metal toxicity in an urban marsh. - Urban Habitats 2: 91-111.

Bitušík, P. 2004b. Chironomids (Diptera: Chironomidae) of the mountain lakes in the Tatra Mts. (Slovakia). A review. - Dipterol. bohemoslov. 12, Acta Fac. Ecol., Zvolen 12, Suppl. 1: 25-33.

Bitušík, P. 2004c. Updated check list of nonbiting midges (Chironomidae, Diptera, nematocera) of the Czech and Slovak Republics. - Dipterol. bohemoslov. 12, Acta Fac. Ecol., Zvolen 12, Suppl. 1: 149-154.

Bo, T., Fenoglio, S., Agosta, P. e Cucco, M. (2003) 2004a. Distribuzione del macrozoobenthos e disponibilità di CPOM in un torrente ligure (Rio del Giovo, Sassello). Studi trent. Sci. nat., Acta biol. 80: 59-62.

Boothroyd, I. K. G. 2004a. A new species of Naonella Boothroyd (Chironomidae: Orthocladiinae) from New Zealand. - N. Z. Ent. 27: 11-15.

Bychkova, S. and Manko, V. 2004a.Ryanodineinduced calcium release in secretory cells of Chironomus plumosus larvae salivary glands. - Visn. lviv. Univ. Ser. biol. 35: 244-250.

Callisto, M., Goulart, M., Medeiros, A. O., Moreno, P. and Rosa, C. A. 2004a. Diversity assessment of benthic macroinvertebrates, yeasts, and microbiological indicators along a longitudinal gradient in Serra do Cipó, Brazil. - Braz. J. Biol. 64: 743-755.

Clague, J. J., Wohlfarth, B., Ayotte, J., Eriksson, M., Hutchinson, I. Mathewes, R. W., Walker, I. R. and Walker, L. 2004a. Late Holocene environmental change at treeline in the northern Coast Mountains, British Columbia, Canada. - Quat. Sci. Rev. 23: 2413-2431.

Dominiak, P. 2004a. Ochotkowate z plemienia Tanytarsini (Diptera: Chironomidae) znad Jezior Raduńskich. (Chironomid midges of the tribe Tanytarsini (Diptera: Chironomidae) 
from above the area of the Radunia Lakes.) Dipteron 20: 7-10.

Fonseca, A. L. and Rocha, O. 2004a. Laboratory cultures of the native species Chironomus xanthus Rempel, 1939 (Diptera-Chironomidae). - Acta limnol. bras. 16: 153-161.

Grzybkowska, M. a Dukowska, M. 2004a. Zależności troficzne $\mathrm{w}$ faunae fitofilnej. (Trophic relations in the epiphytic fauna). Dipteron 20: 14-16.

Grzybkowska, M. and Dukowska, M. 2004b. Response of chironomids (Chironomidae, Diptera) to damming. Production. - Teka Komisji Ochrony i Kształtowania Środowiska Przyrodniczego (= Teka Archs Commn Protect. Format. nat. Envir.) 1: 71-82.

Hamerlík, L. 2004a. Chironomids (Diptera: Chironomidae) of the littoral zone of some lakes in the High Tatra Mts. (Slovakia). Dipterol. bohemoslov. 12, Acta Fac. Ecol., Zvolen 12, Suppl. 1: 49-56.

Heinrichs, M. L., Evans, M. G., Hebda, R. J., Walker, I. R., Palmer, S. L. and Rosenberg, S. A. 2004a. Holocene climatic change and landscape response at Cathedral Provincial Park, British Columbia, Canada. - Géogr. phys. Quat. 58: 123-139.

Hirabayashi, K., Matsuzawa, M., Yamamoto, M., Tanizaki, M., Tomari, H. and Nakamoto, N. 2004a. (Comparison of chironomid fauna in filtration plants at two different climatic areas in Japan.) - Pest Control Res. 19: 77-88.

Idowu, R. T., Inyang, N. M. and Mgbenka, B. O. 2004a. Diptera community in the littoral zone of a North East arid zone lake (Lake Alau), Maiduguri, Borno State, Nigeria. - Bio-Res. 2: 67-74.

Kitagawa, N. 2004a. (Taxonomic studies on chironomid larvae (6).) - Tansui Seibutsu 89: 1-124.

Kubovčík, V. 2004a. Chironomid tanatocenoses (Diptera: Chironomidae) in the sediments of the lakes of the High Tatra Mts. - Dipteron 20: 21-22.

Kubovčík, V. and Beták, M. 2004a. Ninety years of environmental changes in Lake Vyšné Temnosmrečinské pleso (the High Tatra Mts.) inferred from chironomid records. - Dipterol. bohemoslov. 12, Acta Fac. Ecol., Zvolen 12, Suppl. 1: 85-92.

Kubovčík, V. and Fečkaninová, G. 2004a. Subfossil chironomids (Diptera: Chirono- midae) from the sediments of the Ladové pleso lake (High Tatra Mts., Slovakia). Dipterol. bohemoslov. 11, Folia Fac. Sci. nat. Univ. Masaryk. brun., Biol. 109: 173-182.

Lucadamo, L., Battegazzore, M., Morisi, A., Arcidiacono, G., Arena, D., Gallo, M., Stabile, A. e Gallo, L. (2003) 2004a. Rilevamento della qualità biologica dei principali corsi d'acqua del Parco Nazionale del Pollino. - Studi trent. Sci. nat., Acta biol. 80: 119-121.

Marchese, M. y Paggi, A. 2004a. Diversidad de Oligochaeta (Annelida) y Chironomidae (Diptera) del litoral fluvial Argentino. - In: Aceñolaza, F. G. (ed.): Temas de la biodiversidad del litoral fluvial argentino. INSUGEO, Miscelánea, 12: 217-224.

Medina, A. I. y Paggi, A. C. 2004a. Composición y abundancia de Chironomidae (Diptera) en un río serrano de zona semiárida (San Luis, Argentina). - Revta Soc. ent. Argent. 63: 107118.

Okuda, T. 2004b. Cryptobiosis: Extreme desiccation tolerance in the sleeping chironomid, Polypedilum vanderplanki. Zool. Sci. 21: 1217-1218.

Röhrig, R., Beug, H.-J., Trettin R. and Morgenstern , P. 2004a. Subfossil chironomid assemblages as paleoenvironmental indicators in Lake Faulersee (Germany). - Studia quatern. 21: 117-127.

Sharma, O. P., Tripathi, N .K. and Khanna, P. 2004a. Karyotypic analysis of Chironomus plumosus form B (Diptera, Chironomidae) from Jammu region (India). - Perspect. Cytol. Genet. 11, Suppl. 1: 595-608.

Solimini, A. G. e Carchini, G. (2003) 2004a. La produzione degli invertebrati bentonici nell'alto e medio corso del Fiume Aniene. Studi trent. Sci. nat., Acta biol. 80: 37-41.

Soszyńska, A. 2004a. The influence of environmental factors on the supranivean activity of flies (Diptera) in Central Poland. - Eur. J. Ent. 101: 481-489.

Szczerkowska, E., Grzybkowska, M., Dukowska, M. and Tszydel, M. 2004a. Influence of flow disturbances on a macrobenthic community in a lowland river. - Teka Komisji Ochrony i Ksztaltowania Środowiska Przyrodniczego (= Teka Archs Commn Protect. Format. nat. Envir.) 1: 237-248.

Takeda, A. M., Kobayashi, J. T., Resende, D. L. M. C., Fujita, D. S., Avelino, G. S., Fujita, R. 
H., Pavan, C. B. and Butakka, C. M. M. 2004a. Influence of decreased water level on the Chironomidae community of the Upper Paraná River alluvial plain. - In: Agostinho, A. A., Rodrigues, L., Gomes, L. C., Thomaz, S, M. and Miranda, L. E. (eds.): Structure and functioning of the Paraná River and its floodplain, pp. 101-106. Ed. Univ. Estad., Maringá.

Tanaka, N., Kobayashi, T., Tanaka, H., Sasa, M., Kayahara, I., Yamaguchi, Y., Hayashi, H. and Kozawa, K. 2004a. (Unexpected contamination of chironomid larvae into tap water.) Pesutorogi Gatsukaishi [= Pest Control Res.] 19: 1-5.

Taşdemir, A., Ustaoğlu, M. R. ve Bal k, S. 2004a. İkizgöl’ün (Bornova, İzmir, Türkiye) Diptera (Insecta) Faunas. (An investigation on the Diptera fauna of Ikizgöl Lake (Bornova, Izmir, Türkiye).) - Su Ürünleri Derg. 21: 263265.

Tsuji, H., Kanno, K. and Katayama, J. 2004a. (Invasion of rooms by small flying insects and their responses to an adhesive light trap.) Pest Control Research 19; NO.1;PAGE.7-15

Wolfe, A. P., Miller, G. H., Olsen, C. A., Forman, S. L., Doran, P. T. and Holmgren, S. U. 2004a. Geochronology of high latitude lake sediments. - In: Pienitz, R., Douglas, M. S. V. and Smol, J. P. (eds): Long-term environmental change in Arctic and Antarctic lakes, pp. 19-52. Kluwer Acad. Publs., Dordrecht.

Zhang, R.-l. and Wang, X.-h. 2004a. A review of the genus Acricotopus KIEFFER (Diptera: Chironomidae) in China. - Ent. sin. 11: 285291.

\section{Supplement to 2005 Current Bibliography}

Balci, P., White, D. S. and Rice, G. $2005 a$. Production and life cycle of Chironomus major (Diptera: Chironomidae) in Kentucky Lake, southwestern Kentucky and northwestern Texas, U.S.A. - Ent. News 116: 353362.

Bal k, S., Ustaoğlu, M. R., Taşdemir, A., Y ld z, S. ve Özbek , M. 2005a. Kuş Gölü (Band rma) Makrobentik Omurgas z Faunas Hakk nda Bir Ön Araşt rma. (A preliminary study on the macrobenthic invertebrate fauna of Kuş Lake (Band rma).) - Su Ürünleri Derg. 22: 347-349.

Barton, D. R., Johnson, R. A., Campbell, L., Petruniak, J. and Patterson, M. 2005a. Effects of round gobies (Neogobius melanostomus) on dreissenid mussels and other invertebrates in Eastern Lake Erie, 2002-2004. - J. Gt Lakes Res. 31, Suppl. 2: 252-261.

Belyanina, S. I. S. i Durnova , N. A. 2005a. Kariotip I kariofond khironomid Polypedilum (Pentapedilum) sordens (Diptera, Chironomidae) iz vodoemov Saratovskoi obl. (Karyotype and karyofund of chironomids Polypedilum (Pentapedilum) sordens (Diptera, Chironomidae).) - Tsitologiya 47: 366-372.

Belyanina, S. I., Polukonova, N. V. i Zinchenko, T. D. 2005a. Kariotip i morfologiya lichinki komara-zvontsa roda Chironomus (Chironomidae, Diptera) iz Kaspiiskogo morya. (Karyotype and morphology of larvae of Chironomus (Chironomidae, Diptera) from the Caspian Sea.) - Tsitologiya 47: 331-337.

Benn, D. I. and Ballantyne, C. K. 2005a. Palaeoclimatic reconstruction from Loch Lomond Readvance glaciers in the West Drumochter Hills, Scotland. - J. Quatern. Sci. 20: 577-592.

Bruns, D. A. 2005a. Macroinvertebrate response to land cover, habitat, and water chemistry in a mining-impacted river ecosystem: A GIS watershed analysis. - Aquat. Sci. 67: 403-423.

Bubinas, A. and Vaitonis, G. 2005a. The structure and seasonal dynamics of zoobenthic communities in the northern and central parts of the Curonian Lagoon. - Acta zool. lituan. 15: 297-304.

Chandra, S., Vander Zanden, M. J., Heyvaert, A. C., Richards, B. C., Allen, B. C. and Goldman, C. R. 2005a. The effects of cultural eutrophication on the coupling between pelagic primary producers and benthic consumers. - Limnol. Oceanogr. 50: 13681376.

Cho, E.-a. 2005a. Bioturbation as a novel method to characterize the toxicity of aquatic sediment. - Doct. Diss., N. Carol. St. Univ., Raleigh. 153 pp.

Copp, G. H., Spathari, S. and Turmel, M. 2005a. Consistency of diel behaviour and interactions of stream fishes and invertebrates during summer. - River Res. Applics 21: 75-90.

Correia, A. M., Bandeira, N. and Anastácio, P. M. 2005a.Predator-prey interactions of Procambarus clarkii with aquatic macroinvertebrates in single and multiple prey systems. - Acta oecol. 28: 337-343. 
Dively, G. P. 2005a. Impact of transgenic VIP3A $\mathrm{x}$ Cry1Ab lepidopteran-resistant field corn on the nontarget arthropod community. - Envir. Ent. 34: 1267-1291.

Dutra, S. L. and Callisto, M. 2005a. Macroinvertebrates as tadpole food: importance and body size relationships. Revta bras. Zool. 22: 923-927.

Edwards, D. D. 2005a. In search of fluctuating asymmetry: no evidence among Chironomus tentans (Diptera: Chironomidae) parasitized by the ectoparasitic water mite Unionicola foili (Acari: Unionicolidae). - Acarologia 44: 209-217.

Elliott, J. M.2005b. Ontogenetic shifts in the functional response and interference interactions of Rhyacophila dorsalis larvae (Trichoptera). - Freshwat. Biol. 50: 20212033.

Félix dos Anjos, A. e Takeda, A. M. 2005a. Colonização de Chironomidae (Diptera: Insecta) em diferentes tipos de substratos artificiais. - Acta Scient. biol. Sci. 27: 147151.

Fenoglio, S., Bo, T. and Cucco, M. 2005a. Winter prey preference of Perlodes microcephalus (Pictet, 1833) (Plecoptera, Perlodidae) nymphs in an Apenninic creek, northwestern Italy. - Ent. News 116: 245-252.

Ferrarese, U. (2004) 2005a. Paraboreochlus minutissimus (Strobl, 1894): primo ritrovamento di Podonominae (Diptera, Chironomidae) in Italia. - Studi trent. Sci. nat., Acta biol. 81: 139-143.

Fu, X.-m., Wang, Y.-t. and Q., X. 2005a. (Bioaccumulation of phosphorus by chironomid larvae in plain reservoirs at the Yellow River Delta.) - J. Agro-Envir. Sci. 24: 134136.

Garbary, D. J., Jamieson, M. M., Fraser, S. J., Ferguson, C. A. and Cranston, P. S. 2005a. Ascophyllum (Phaeophyceae) and its symbionts. IX. A novel symbiosis between Halocladius variabilis (Chironomidae, Insecta) and Elachista fucicola (Elachistaceae, Phaeophyceae) from marine rocky shores of Nova Scotia. - Symbiosis 40: 61-68.

Giłka, W. 2005b. Deformacje ciała imagines ochotkowatych (Diptera: Chironomidae) skutkiem oddziaływania pasożytniczych nicieni. (Morphological deformations of adult non-biting midges (Diptera: Chironomidae) as a result of parasitic activity.) - Dipteron 21: 911.

Glaser, R., Ammann, B., Brauer, A., Heiri. O., Jacobeit, J., Lotter, A. F., Luterbacher, J., Maisch, M., Magny, M., Pfister, C., Tinner, W., Veit, H. and Wanner, H. 2005a. Palaeoclimate within the river Rhine catchment during Holocene and historic times. - Erdkunde 59 251-275.

Grzybkowska, M. 2005a. Jak przeżyć w trudnych warunkach - strategie ochotek. (How to survive in hard conditions - the chironomids strategies.) - Dipteron 21: 13.

Habashy, M. M. 2005a. Culture of chironomid larvae (Insecta - Diptera - Chironomidae) under different feeding systems. - Egypt. J. aquat. Res. 31: 403-418.

Halkiewicz, A. 2005a. Subfossil remains of Chironomidae from two shallow lakes representing extreme alternative states. Studia quatern. 22: 45-49.

Hamerlík, L. 2005a. Three new records of chironomids (Diptera, Chironomidae) from Slovakia. - Biologia, Bratisl. 60: 566.

Higuti, J., Pessanha Zviejkovski, I., Avelar Takahashi, M. e Gonçalves Dias, V. 2005a. Chironomidae indicadora do estado trófico em reservatórios. - In: Rodrigues, L., Thomaz, S. M., Agostinho, A. A. e Gomes, L. C. (eds.): Biocenoses em reservatórios: Padrões espaciais e temporais, pp. 137-145. RiMa, São Carlos.

Kikawada, T., Minakawa, N., Watanabe, M. and Okuda, T. 2005a. Factors inducing successful anhydrobiosis in the African chironomid Polypedilum vanderplanki : significance of the larval tubular nest. - Integrat. comp. Biol. 45: $710-714$.

Kubovčík, V. 2005a. Environmental history of an alpine lake: a palaeolimnological study of Zmarzły Staw lake (High Tatra Mts, Poland). - Dipteron 21: 14-15.

Kwak, I.-S. and Lee, W. 2005d. (The mentum deformity of $C$. plumosus following exposure to endocrine disruption chemicals.) - Korean J. Limnol. 38, Ser. No. 110: 11-17.

Lee, K. E., Sanocki, C. A. and Montz, G. R. 2005a. Physical, chemical, and biological characteristics of Sturgeon Lake, Goodhue County, Minnesota, 2003-04. - Scient. Invest. Rep. 2005-5182. U. S. Dep. Inter., U. S. Geol. Surv., Mounds View. 6+21 pp. 
Makarchenko, E. A. 2005a. A new species of Arctodiamesa Makarchenko (Diptera: Chironomidae: Diamesinae) from the Russian Far East, with a key to known species of the genus. - Zootaxa 1084: 59-64.

Makarchenko, E. A. i Makarchenko, M. A. 2005d. A new species, Aagardia oksanae sp. n. (Diptera, Chironomidae, Orthocladiina) from the Sikhote-Alin' Biosphere Nature Reserve. - Evraziat. ent. Zh. (= Euroas. ent. J.) 4: 235-236.

Manko, V. i Velykopolska, O. 2005a. (Identification of purinergic receptors in secretory cells of salivary gland of Chironomus plumosus larvae.) - Visn. Lviv. Univ. Ser. Biokhim. 40: 134-139.

Marziali, L., Lencioni, V., Boggero, A. e Rossaro, B. 2005a. Distribuzione di Ditteri Chironomidi in laghi alpini e prealpini. Biogeografia delle Alpi e Prealpi centroorientali. Biogeographia 62: 431-445.

Monroe, J. B., Poff, N. L. and Thorp, R. A. 2005a.Natural history of a retreat-building midge, Pagastia partica, in a regulated reach of the upper Colorado River. - West. N. Am. Nat. 65: 451-461.

Morrison, L. W. 2005a. Arthropod diversity and allochthonous-based food webs on tiny oceanic islands. - Divers. Distrib. 11: 517524.

Nakazato, R., Tsuchiya, T., Muramatsu, M., Higo, M., Sakurai, H., Saji, A. and Naya, T. 2005a. (Horizontal distribution and long-term trends in population densities of chironomid larvae in Lake Kitaura, Ibaraki Prefecture, Japan.) - Jap. J. Limnol. 66: 165-180.

Ogendi, G. M., Brumbaugh, W., Hannigan, R. and Farris, J. 2005a. Effects of acid volatile sulfide on black shale sediment-metal bioavailability and toxicity to Chironomus tentans. - Abstr. Progm Geol. Soc. Am. a. Meet. 37: 454.

Okuda, T. 2005a. The sleeping chironomid, Polypedilum vanderplanki: A physiological strategy to survive at extreme environmental conditions. - Zool. Sci. 22: 1405-1406.

Péry, A. R. R., Mons, R. and Garric, J. 2005b. Chironomus riparius solid-phase assay. - In: Blaise, C. and Férard, J.-F. (eds.): Small-scale freshwater toxicity investigations 1: Toxicity test methods, pp. 437-451. Springer, Dordrecht.
Płóciennik, M. 2005a. Zastosowanie subfosylnych szczątków ochotkowatych (Diptera: Chironomidae) w badaniach nad paleoklimatem i rekonstrukcją zmian w środowisku. (Thanatocenoses of non-biting midges (Diptera: Chironomidae) in paleoclimatic and environmental researches.) Kosmos 54: 401-406.

Polukonova, N. V. 2005c. (Chironomus paraalbidus sp. n. (Chironomidae: Diptera) from the Caspian Sea.) - Zool. Zh. 84: 10171024.

Rosenberg, S. M., Walker, I. R. and Macpherson, J. B. 2005a. Environmental changes at Port au Choix as reconstructed from fossil midges. Newfoundland Labrador Stud. 20: 57-73.

Rossaro, B., Lencioni, V. e Marziali, L. (2004) 2005a. L'importanza della tassonomia nel monitoraggio biologico. - Studi trent. Sci. nat., Acta biol. 81: 31-36.

Stief, P., Nazarova, L. and De Beer, D. 2005a. Chimney construction by Chironomus riparius larvae in response to hypoxia: microbial implications for freshwater sediments. - J. N. Am. benthol. Soc. 24: 858871.

Sun, X., Cui, F., Zhang, J., Guo, Z., Xu. F. and Liu, L. 2005b. Experimental study on the inactivation effects of alternative oxidants on the chironomid larvae. - Acta Scient. Circumstantiae 25: 930-935.

Takeda, A. M., Butakka, C. M. M., Fujita, D. S., Fujita, R. H., Bibian, J. P. R. 2005a. Larvas de Chironomidae em Cascata de Reservatórios no Rio Iguaçu (PR). - In: Rodrigues, L., Thomaz, S. M., Agostinho, A. A. e Gomes L. C.(eds.): Biocenoses em Reservatórios Padrões espaciais e temporais 1: 147-159. Ed. RiMa, São Carlos.

Taşdemir, A. ve Ustaoğlu, M. R. 2005a. Göller Bölgesi içsularn n Chironomidae ve Chaoboridae (Diptera) faunas n n taksonomik yönden incelenmesi. (Taxonomical investingation of Lake District inland waters Chironomidae and Chaoboridae (Diptera) fauna.) - Su Ürünleri Derg. 22: 377-384.

Thackray, G. D., Shulmeister, J. P., Rieser, U., Marra, M. and Woodward, C. 2005a. New OSL glacial chronology from the Rakaia Valley, New Zealand. - Abstr. Progm Geol. Soc. Am. a. Meet. 37: 40.

Toksöz, A. ve Ustaoğlu , M. R. 2005a. Gölcük Gölü’nün (Bozdağ, Ödemiş) Profundal 
Makrobentik Faunas Üzerine Araşt rmalar. (An investigation on the profundal macrobenthic fauna of Gölcük Lake (Bozdağ, Ödemiş).) - Su Ürünleri Derg. 22: 173-175.

Trzcinski, M. K., Walde, S. J. and Taylor, P. D. 2005a. Local interactions in pitcher plant communities scale-up to regional patterns in distribution and abundance. - Envir. Ent. 34: 1464-1470.

Tuno, N., Okeka, W., Minakawa, N., Takagi, M. and Yan, G. 2005a. Survivorship of Anopheles gambiae sensu stricto (Diptera: Culicidae) larvae in western Kenya highland forest. - $J$. med. Ent. 42: 270-277.

Uchmann, A. 2005a. Treptichnus-like traces made by insect larvae (Diptera; Chironomidae, Tipulidae). - In: Buta, R. J., Rindsberg A. K and Kopaska-Merkel, D. C. (eds.): Pennsylvanian footprints in the Black Warrior Basin of Alabama. Ala. paleont. Soc. Monogr. 1: 143-146.

Wagner, B., Heiri, O. and Hoyer, D. 2005a. Chironomids as palaeoenvironmental proxies in East Greenland: a first Holocene record from Geographical Society Ø. - Z. dt. Ges. Geowiss. 156: 543-556.

Whitney, B. S., Vincent, J. H. and Cwynar, L. C. 2005a. A midge-based late-glacial temperature reconstruction from southwestern Nova Scotia. - Can. J. Earth Sci. 42: 20512057.

Willassen, E., Hanssen,O. and Koksvik, J. I. 2005a. Diamesa parancysta Serra-Tosio: and East-Palearctic midge new to Europe (Diptera: Chironomidae: Diamesinae). - Norw. J. Ent. 52: 69-73.

Yamamoto, Y., Iwafune, T., Yoshida, N. and Hirabayashi, K. 2005a. (Fatty acid composition in chironomid larvae in Lakes Kawaguchi and Shibire, Japan.) - Jap. J. Limnol. 66: 181-190.

Yan, Y.-J. and Li, X.-J. 2005a. (Production dynamics and trophic basis of two chironomids in Heizhuchong Stream, Hubei, China.) - Acta ecol. sin. 25: 3127-3132.

\section{Current bibliography 2006}

Adams, S. R., Flinn, M. B., Burr, B. M., Whiles, M. R. and Garvey, J. E.2006a. Ecology of larval blue sucker (Cycleptus elongatus) in the Mississippi River. - Ecol. Freshwat. Fish 15: 291-300.
Aditya, G. and Saha, G. K. 2006a. Predation of the beetle Rhantus sikkimensis (Coleoptera: Dytiscidae) on the larvae of Chironomus Meigen (Diptera: Chironomidae) of the Darjeeling Himalayas of India. - Limnologica 36: 251-257.

Akin, S. and Winemiller, K. O. 2006a. Seasonal variation in food web composition and structure in a temperate tidal estuary. Estuaries Coasts 29: 552-567.

Alford, J. B. and Beckett, D. C. 2006a. Dietary specialization by the speckled darter, Etheostoma stigmaeum, on chironomid larvae in a Mississippi stream. - J. Freshwat. Ecol 21: 543-552.

Allegrucci, G., Carchini, G., Todisco, V., Convey, P. and Sbordoni, V. 2006a. A molecular phylogeny of antarctic Chironomidae and its implications for biogeographical history. - Polar Biol. 29: 320326.

Al-Shami, S. A., Che Salmah, M. R., Siti Azizah, M. N., Abu Hassan, A. and Azmi, M. 2006a. Toxicity of two herbicides 2,4-D dimethylamine and bensulfuron methyl to rice field Chironomus kiiensis (Tokunaga) (Diptera: Chironomidae). - Wetland Sci. 4: 241-246.

Andersen, D. C. and Nelson, S. M. 2006a. Flood pattern and weather determine Populus leaf litter breakdown and nitrogen dynamics on a cold desert floodplain. - J. arid Envir. 64: 626-650.

Andersen, F. Ø., Jørgensen, M. and Jensen, H. S. 2006a. The influence of Chironomus plumosus larvae on nutrient fluxes and phosphorus fractions in aluminum treated lake sediment. - Wat. Air Soil Pollut. Focus 6: 465474.

Anderson, B. S., Phillips, B. M., Hunt, J. W., Connor, V., Richard, N. and Tjeerdema, R. S. 2006a. Identifying primary stressors impacting macroinvertebrates in the Salinas River (California, USA): Relative effects of pesticides and suspended particles. - Envir. Pollut. 141: 402-408.

Andersson, J., Johansson, F. and Söderlund, T. 2006a. Interactions between predator- and diet-induced phenotypic changes in body shape of crucian carp. - Proc. R. Soc. Lond., Ser. B: biol. Sci. 273: 431-437.

Angradi, T. R., Schweiger, E. W. and Bolgrien, D. W. 2006a. Inter-habitat variation in the 
benthos of the Upper Missouri River (North Dakota, USA): implications for Great River bioassessment. - River Res. Applics 22: 755773.

Anteau, M. J. and Afton, A. D. 2006a. Diet shifts of lesser scaup are consistent with the spring condition hypothesis. - Can. J. Zool. 84: 779786.

Antonsson, K., Brooks, S. J., Seppä, H., Telford, R. J. and Birks, H. J. B. 2006a. Quantitative palaeotemperature records inferred from fossil pollen and chironomid assemblages from Lake Gilltjärnen, northern central Sweden. - J. Quatern. Sci. 21: 831-841.

Arav, D. and Blaustein, L. 2006a. Effects of pool depth and risk of predation on oviposition habitat selection by temporary pool dipterans. - J. med. Ent. 43: 493-497.

Armitage, P. D. 2006a. Long-term faunal changes in a regulated and an unregulated stream Cow Green thirty years on. - River Res. Applics 22: 947-966.

Arnwine, D. H., Sparks, K. J. and James, R. R. 2006a. Probabilistic monitoring of streams below small impoundments in Tennessee. Tenn. Dep. Envir. Conserv., Div. Wat. Pollut. Control, Nashville. 282 pp.

Arroyo, N. L., Aarnio, K. and Bonsdorff; E. 2006a. Drifting algae as a means of recolonizing defaunated sediments in the Baltic Sea. A short-term microcosm study. Hydrobiologia 554: 83-95.

Arscott, D. B., Jackson, J. K. and Kratzer, E. B. 2006a. Role of rarity and taxonomic resolution in a regional and spatial analysis of stream macroinvertebrates. - J. N. Am. benthol. Soc. 25: 977-997.

Arslan, N. and Şahin, Y. 2006a. A preliminary study on the identification of the littoral oligochaete (Annelida) and Chironomidae (Diptera) fauna of Lake Kovada, a National Park in Turkey. - Turk. J. Zool. 30: 67-72.

Ashauer, R., Boxall, A. and Brown, C. 2006a. Predicting effects on aquatic organisms from fluctuating or pulsed exposure to pesticides. Envir. Toxic. Chem 25: 1899-1912.

Azrina, M. Z., Yap, C. K., Rahim Ismail, A., Ismail, A. and Tan, S. G. 2006a. Anthropogenic impacts on the distribution and biodiversity of benthic macroinvertebrates and water quality of the Langat River, Peninsular Malaysia. - Ecotoxic. envir. Saf. 64: 337-347.
Bahrndorff, S, Ward, J, Pettigrove, V. and Hoffmann, A. A. 2006a. A microcosm test of adaptation and species specific responses to polluted sediments applicable to indigenous chironomids (Diptera). - Envir. Pollut. 139: 550-560.

Balcombe, S. R. and Humphries, P. 2006a. Diet of the western carp gudgeon (Hypseleotris klunzingeri Ogilby) in an Australian floodplain lake: the role of water level stability. - J. Fish Biol. 68: 1484-1493.

Bal k, S., Ruşen Ustaoğlu, M., Özbek, M., Y ld z, S., Taşdemir, A. ve İlhan, A. 2006a. Küçük Menderes Nehri’nin (Selçuk, İzmir) Aşağ Havzas ndaki Kirliliğin Makro Bentik Omurgas zlar Kullan larak Saptanmas . (Determination of pollution at lower basin of Küçük Menderes River (Selçuk, İzmir) by using macro benthic invertebrates.) - Su Ürünleri Derg. 23: 61-65.

Barley, E. M., Walker, I. R., Kurek, J., Cwynar, L. C., Mathewes, R. W., Gajewski, K. and Finney, B. P. 2006a. A northwest North American training set: distribution of freshwater midges in relation to air temperature and lake depth. - J. Paleolimnol. 36: 295314.

Beaty, S. R., Fortino, K. and Hershey, A. E. 2006a. Distribution and growth of benthic macroinvertebrates among different patch types of the littoral zones of two arctic lakes. Freshwat. Biol. 51: 2347-2361.

Beauger, A., Lair, N., Reyes-Marchant, P. and Peiry, J.-L. 2006a. The distribution of macroinvertebrate assemblages in a reach of the River Allier (France), in relation to riverbed characteristics. - Hydrobiologia 571: 63-76.

Becher, P. G. and Jüttner, F. 2006a. Insecticidal activity - a new bioactive property of the cyanobacterium Fischerella. - Pol. J. Ecol. 54: 653-662.

Becker, A., Ammann, B., Andelmetti, F. S., Hirt, A. M., Magny, M., Millet, L, Rachoud, A.-M., Sampietro, G. and Wütherich, C. 2006a. Paleoenvironmental studies on Lake Bergsee, Black Forest, Germany. - Neues Jb. Geol. Palaeont. Abh. 240: 405-445.

Belanger, S. E., Dorn, P. B., Toy, R., Boeije, G., Marshall, S. J., Wind, T., Van Compernolle, R. and Zeller, D. 2006a. Aquatic risk assessment of alcohol ethoxylates in North America and Europe. - Ecotoxic. envir. Saf. 64: 85-99. 
Belden, J. B. and Lydy, M. J. 2006a. Joint toxicity of chlorpyrifos and esfenvalerate to fathead minnows and midge larvae. - Envir. Toxic. Chem. 25:623-629.

Benn, D. I. and Lukas, S. 2006a. Younger Dryas glacial landsystems in North West Scotland: an assessment of modern analogues and palaeoclimatic implications. - Quatern. Sci. Rev. 25: 2390-2408.

Bhattacharyay, G., Sadhu, A. K., Mazumdar, A., Majumdar, U., Chaudhuri, P. K. and Ali, A. 2006a. Assessment of impact of heavy metals on the communities and morphological deformities of Chironomidae larvae in the River Damodar (India, West Bengal). Supplta Acta hydrobiol., Kraków 8: 21-32.

Bidwell, J. R. and Gorrie, J. R. 2006a. The influence of salinity on metal uptake and effects in the midge Chironomus maddeni. Envir. Pollut. 139: 206-213.

Bigler, C., Barnekow, L., Heinrichs, M. L. and Hall, R. I. 2006a. Holocene environmental history of Lake Vuolep Njakajaure (Abisko National Park, Northern Sweden) reconstructed using biological proxy indicators. - Veget. Hist. Archaeobot. 15: 309320.

Bigler, C., Heiri, O., Krskova, R., Lotter, A. F. and Sturm, M. 2006a. Distribution of diatoms, chironomids and cladocera in surface sediments of thirty mountain lakes in southeastern Switzerland. - Aquat. Sci. 68: 154-171.

Bilton, D. T., McAbendroth, L., Bedford, A. and Ramsay, P. M. 2006a. How wide to cast the net? Cross-taxon congruence of species richness, community similarity and indicator taxa in ponds. - Freshwat. Biol. 51: 578-590.

Bitušík, P. 2006a. First faunistic records of chironomids (Diptera, Chironomidae) from Slovakia. - Biologia, Bratisl. 61: 157-158.

Bitušík, P. 2006b. Faunistic records. Chironomidae. - In: Kinkorová, J. (ed.): Dipterol. bohemoslov. 13, Acta Univ. carol., Biol. 50: 142.

Bitušík, P., Hamerlík, L. and Haviar, M. 2006a. First records of chironomids (Diptera, Chironomidae) from Slovakia. - Biologia, Bratisl. 61: 639-641.

Bitušík, P., Svitok, M., Kološta, P. and Hubková, M. 2006a. Classification of the Tatra Mountain lakes (Slovakia) using chironomids (Diptera, Chironomidae). - Biologia, Bratisl. 61, Suppl. 18: S191-S201.
Björk, P., Wetterberg-Strandh, I., Baurén, G. and Wieslander, L. 2006a. Chironomus tentansrepressor splicing factor represses SR protein function locally on pre-mRNA exons and is displaced at correct splice sites. - Molec. Biol. Cell 17: 32-42.

Blom, J. F., Baumann, H. I., Codd, G. A. and Jüttner, F. 2006a. Sensitivity and adaptation of aquatic organisms to oscillapeptin $\mathrm{J}$ and [DAsp3, (E)-Dhb7]microcystin-RR. - Arch. Hydrobiol. 167: 547-559.

Bo, T., Cucco, M., Fenoglio, S. and Malacarne, G. 2006a. Colonisation patterns and vertical movements of stream invertebrates in the interstitial zone: a case study in the Apennines, NW Italy. - Hydrobiologia 568: 67-78.

Bohman, I. M. and Herrmann, J. 2006a. The timing of winter-growing shredder species and leaf litter turnover rate in an oligotrophic lake, SE Sweden. - Hydrobiologia 556: 99-108.

Boggero, A. and Lencioni, V. 2006a. Macroinvertebrates assemblages of high altitude lakes, inlets and outlets in the southern Alps. - Arch. Hydrobiol. 165: 37-61.

Boggero, A., Füreder, L., Lencioni, V., Simcic, T., Thaler, B., Ferrarese, U., Lotter, A. F. and Ettinger, R. 2006a. Littoral chironomid communities of Alpine lakes in relation to environmental factors. - Hydrobiologia 562: 145-165.

Borcherding, J., Scharbert, A. and Urbatzka, R. 2006a. Timing of downstream migration and food uptake of juvenile North Sea houting stocked in the Lower Rhine and theLippe (Germany). - J. Fish Biol. 68: 1271-1286.

Bouchard, R. W., Carrillo, M. A. and Ferrington, L. C. 2006a. Lower lethal temperature for adult male Diamesa mendotae Muttkowski (Diptera: Chironomidae), a winter-emerging aquatic insect. - Aquat. Insects 28: 57-66.

Bouchard, R. W. Jr., Carrillo, M. A., Kells, S. A. and Ferrington, L. C. Jr. 2006a. Freeze tolerance in larvae of the winter-active Diamesa mendotae Muttkowski (Diptera: Chironomidae): a contrast to adult strategy for survival at low temperatures. - Hydrobiologia 568: 403-416.

Boyero, L., Pearson, R. G. and Camacho, R. 2006a. Leaf breakdown in tropical streams: the role of different species in ecosystem functioning. - Arch. Hydrobiol. 166: 453-466. 
Brabec, K. and Langton, P. H. 2006a. Faunistic records. Chironomidae. - In: Kinkorová, J. (ed.): Dipterol. bohemoslov. 13, Acta Univ. carol., Biol. 50: 143-145.

Brainwood, $M$ and Burgin, S. 2006a. An exploration of the relationships between macroinvertebrate community composition and physical and chemical habitat characteristics in farm dams. - Envir. Monit. Assess. 119: 459-480.

Bressler, D. W., Stribling, J. B., Paul, M. J. and Hicks, M. B. 2006a. Stressor tolerance values for benthic macroinvertebrates in Mississippi. - Hydrobiologia 573: 155-172.

Briner, J. P., Michelutti, N., Francis, D. R., Miller, G. H., Axford, Y., Wooller, M. J. and Wolfe, A. P. 2006a. A multi-proxy lacustrine record of Holocene climate change on northeastern Baffin Island, Arctic Canada. Quatern. Res. 65: 431-442.

Brodersen, K. P. and Quinlan, R. 2006a. Midges as palaeoindicators of lake productivity, eutrophication and hypolimnetic oxygen. Quatern. Sci. Rev. 25: 1995-2012.

Brooks, S. J. 2006a. Fossil midges (Diptera: Chironomidae) as palaeoclimatic indicators for the Eurasian region. - Quatern. Sci. Rev. 25: 1894-1910.

Brown, L. E. ,Milner, A. M. and Hannah, D. M. 2006a. Stability and persistence of alpine stream macroinvertebrate communities and the role of physicochemical habitat variables. - Hydrobiologia 560: 159-173.

Burlakova, L. E., Padilla, D. K., Karatayev, A. Y. and Minchin, D. 2006a. Endosymbionts of Dreissena polymorpha in Ireland: Evidence for the introduction of adult mussels. - $J$. Mollusc. Stud. 72: 207-210.

Burmester, T., Storf, J., Hasenjäger, A., Klawitter, S. and Hankeln, T. 2006. The hemoglobin genes of Drosophila. - FEBS J. 273: 468-480.

Byström, P., Andersson, J., Kiessling, A. and Eriksson, L.-O. 2006a. Size and temperature dependent foraging capacities and metabolism: consequences for winter starvation mortality in fish. - Oikos 115: 4352.

Cabrerizo Ballesteros, S., de Barrio, M., Baeza, M. L. and Rubio Sotés, M. 2006a. Allergy to chironomid larvae (red migde [sic!] larvae) in non professional handlers of fish food. - $J$. invest. Allergol. clin. Immunol. 16: 63-68.
Calle-Martínez, D. and Casas, J. J. 2006a. Chironomid species, stream classification, and water-quality assessment: the case of 2 Iberian Mediterranean mountain regions. - J. N. Am. benthol. Soc. 25: 465-476.

Callisto, M., Goulart, M. D. C., Moreno, P. and Martins, R. P. 2006a. Does predator benefits prey? Commensalism between Corynoneura Winnertz (Diptera, Chironomidae) and Corydalus Latreille (Megaloptera, Corydalidae) in Southeastern Brazil. - Revta bras. Zool. 23: 569-572.

Camur-Elipek, B., Arslan, N., Kirgiz, T. and Oterler, B. 2006a. Benthic macrofauna in Tunca River (Turkey) and their relationships with environmental variables. - Acta hydrochim. hydrobiol. 34: 360-366.Caquet, T. 2006a. Use of carbon and nitrogen stable isotope ratios to assess the effects of environmental contaminants on aquatic food webs. - Envir. Pollut. 141: 54-59.

Cardona, L. 2006a. Trophic cascades uncoupled in a coastal marsh ecosystem. - Biol. Invasions 8: 835-842

Carman, S. M., Janssen, J., Jude, D. J. and Berg, M. B. 2006a. Diel interactions between prey behaviour and feeding in an invasive fish, the round goby, in a North American river. Freshwat. Biol. 51: 742-755.

Carter, G. S., Nalepa, T. F. and Rediske, R. R. 2006a. Status and trends of benthic populations in a coastal drowned river mouth lake of Lake Michigan. - J. Gt Lakes Res. 32: 578-595.

Casas, J. J., Gessner, M. O., Langton, P. H., Calle, D., Descals, E. and Salinas, M. J. 2006a. Diversity of patterns and processes in rivers of eastern Andalusia. - Limnetica 25: 155-170.

Caseldine, C., Langdon, P. and Holmes, N. 2006a. Early Holocene climate variability and the timing and extent of the Holocene thermal maximum (HTM) in northern Iceland. Quatern. Sci. Rev. 25: 2314-2331.

Caseldine, C., Langdon, P. and Holmes, N. 2006b. Quantitative terrestrial palaeoclimatic records from Iceland; a comparison with marine data. - Am. Geophys. Un. 87. Fall Meet. Suppl. Abstr.: PP23C-1772.

Casper, A. F., Thorp, J. H., Davies, S. P. and Courtemanch, D. L. 2006a. Ecological responses of zoobenthos to dam removal on the Kennebec River, Maine, USA. - Arch. 
Hydrobiol. Suppl. 158, Large Rivers 16: 541555.

Chambers, P. A., Meissner, R., Wrona, F. J., Rupp, H., Guhr, H., Seeger, J., Culp, J. M. and Brua, R. B. 2006a. Changes in nutrient loading in an agricultural watershed and its effects on water quality and stream biota. Hydrobiologia 556: 399-415.

Chara, J. D., Baird, D. J., Telfer, T. C. and Rubio, E. A. 2006a. Feeding ecology and habitat preferences of the catfish genus Trichomycterus in low-order streams of the Colombian Andes. - J. Fish Biol. 68: 10261040.

Chatzinikolaou, Y., Dakos, V. and Lazaridou, M. 2006a. Longitudinal impacts of anthropogenic pressures on benthic macroinvertebrate assemblages in a large transboundary Mediterranean river during the low flow period. - Acta hydrochim. hydrobiol. 34: 453463.

Cheng, M. and Wang, X. H. 2006a. Natarsia Fittkau from China (Diptera: Chironomidae: Tanypodinae). - Zootaxa 1111: 59-67.

Cheng, M. and Wang, X. H. 2006b. Psectrotanypus Kieffer from China (Diptera: Chironomidae: Tanypodinae). - Zootaxa 1128: 49-36.

Cheng, M. and Wang, X. H. 2006c. Hayesomyia Murray and Fittkau from China with emendation of the generic diagnosis (Diptera: Chironomidae: Tanypodinae). - Zootaxa 1147: 35-59.

Cheng, M. and Wang, X. H. 2006d. Nilotanypus Kieffer from China (Diptera: Chironomidae: Tanypodinae). - Zootaxa 1193: 49-57.

Chessman, B. C., Thurtell, L. A. and Royal, M. J. 2006a. Bioassessment in a harsh environment: a comparison of macroinvertebrate assemblages at reference and assessment sites in an Australian inland river system. - Envir. Monit. Assess. 119: 303-330.

Chipps, S. R., Hubbard, D. E., Werlin, K. B., Haugerud, N. J., Powell, K. A., Thompson, J. and Johnson, T. 2006a. Association between wetland disturbance and biological attributes in floodplain wetlands. - Wetlands 26: 497508.

Chester, H. and Norris, R. 2006a. Dams and flow in the Cotter River, Australia: effects on instream trophic structure and benthic metabolism. - Hydrobiologia 572: 275-286.
Claeson, S. M., Li, J. L., Compton, J. E. and Bisson, P. A. 2006a. Response of nutrients, biofilm, and benthic insects to salmon carcass addition. - Can. J. Fish. aquat. Sci. 63: 12301241.

Corbi, J. J. 2006a. Influência de práticas de manejo de solo sobre os macroinvertebrados aquáticos de córregos: ênfase para o cultivo de cana-de-açucar em áreas adjacentes. - $\mathrm{Ph}$. D. Thes., Univ. São Carlos. 92 pp.

Corbi, J. J. and Trivinho-Strixino, S. 2006a. Influence of taxonomic resolution of stream macroinvertebrate communities on the evaluation of different land uses. - Acta limnol. bras. 18: 469-475.

Corbi, J. J. e Trivinho-Strixino, S. 2006b. Ciclo de vida de duas espécies de Goeldichironomus (Diptera, Chironomidae). - Revta bras. Ent. 50: $72-75$.

Correia, L. C. S., Trivinho-Strixino, S. and Michailova, P. 2006a. A new species of Chironomus Meigen (Diptera: Chironomidae: Chironominae) from polluted streams of southeastern Brazil. - Zootaxa 1130: 57-68.

Cranston, P. S. 2006a. A new genus and species of Chironominae (Diptera: Chironomidae) with wood-mining larvae. - Aust. J. Ent. 45: 227-234.

Cranston, P. S. and McKie, B. 2006a. Aquatic wood - an insect perspective. - In: Grove, S. J. and Hanula, J. L., eds.: Insect biodiversity and dead wood: Proc. Symp. $22^{\text {nd }}$ Int. Congr. Ent. Gen. tech. Rep. SRS-93, pp. 9-14. US Dep. Agric., For. Serv., Sth. Res. Stn. Asheville, NC. 109 pp.

Crawford, L., Yeomans, W. E. and Adams, C. E. 2006a. The impact of introduced signal crayfish Pacifastacus leniusculus on stream invertebrate communities. - Aquat. Conserv. mar. Freshwat. Ecosyst. 16: 611-621.

Cronin, G., Lewis, W. M. and Schiehser, M. A. 2006a. Influence of freshwater macrophytes on the littoral ecosystem structure and function of a young Colorado reservoir. Aquat. Bot. 85: 37-43.

Croisetière, L., Hare, L. and Tessier, A. 2006a. A field experiment to determine the relative importance of prey and water as sources of As, $\mathrm{Cd}, \mathrm{Co}, \mathrm{Cu}, \mathrm{Pb}$, and $\mathrm{Zn}$ for the aquatic invertebrate Sialis velata. - Envir. Sci. Technol. 40: 873-879.

Cser, B. és Révész, Á. 2006a. Makrofaunavizsgálatok a Tápión. (Macrofauna- 
investigations on the Tápió-river.) - Hidrol. Közl. 86: 159-160.

Dakon, E., Goethals, P. L. M., D’heyere, T., Dedecker, A. P., Gabriels, W., De Pauw, N. and Lazaridou-Dimitriadou, M. 2006a. Development of artificial neural networks, model predicitions, macroinvertebrate taxa in the river Axios (Northern Greece). - Annls Limnol. 42: 241-250.

Davey, A. J. H., Turner, G. F., Hawkins, S. J.and Doncaster, C. P. 2006a. Mechanisms of density dependence in stream fish: exploitation competition for food reduces growth of adult European bullheads (Cottus gobio). - Can. J. Fish. aquat. Sci. 63: 597-606.

Davy-Bowker, J., Clarke, R. T., Johnson, R. K., Kokes, J., Murphy, J. F. and Zahrádková, S. 2006a. A comparison of the European Water Framework Directive physical typology and RIVPACS-type models as alternative methods of establishing reference conditions for benthic macroinvertebrates. - Hydrobiologia 566: 91-105.

Deák, Cs. 2006a. Módosított síkvidéki kisvízfolyások makroszkópikus gerinctelen együttesei. (Macroinvertebrate communities of small modified lowland streams.) - Hidrol. Közl. 86: 27-29.

De Haas, E. M., Wagner, C., Koelmans, A. A., Kraak, M. H. and Admiraal, W. 2006a. Habitat selection by chironomid larvae: fast growth requires fast food. - J. Anim. Ecol. 75:148-155.

Deines, P. and Grey, J. 2006a. Site-specific methane production and subsequent midge mediation within Esthwaite Water, UK. Arch. Hydrobiol. 167: 317-334.

Devereaux, J. S.-L. and Mokany, A. 2006a. Visual and chemical cues from aquatic snails reduce chironomid oviposition. - Aust. J. Zool. 54: 79-86.

Díez, J. L., Vilariño, V. R., Medina, F. J. and Morcillo, G. 2006a. Nucleolar localization of a reverse transcriptase related to telomere maintenance in Chironomus (Diptera). Histochem. Cell Biol. 125: 445-452.

Doi, H., Kikuchi, E., Takagi, S. and Shikano, S. 2006a. Selective assimilation by deposit feeders: Experimental evidence using stable isotope ratios. - Basic appl. Ecol. 7: 159-166.

Downes, B. J., Lake, P. S., Glaister, A. and Bond, N. R. 2006a. Effects of sand sedimentation on the macroinvertebrate fauna of lowland streams: are the effects consistent? Freshwat. Biol. 51: 144-160.

Dubé, M. G., Benoy, G. A. and Wassenaar, L. I. 2006a. Contrasting pathways of assimilation: stable isotope assessment of fish exposure to pulp mill effluents. - J envir. Qual. 35: 18841893.

Ducrot, V., Cognat, C., Mons, R., Mouthon, J. and Garric, J. 2006a. Development of rearing and testing protocols for a new freshwater sediment test species: the gastropod Valvata piscinalis. - Chemosphere 62: 1272-1281.

Dumnicka, E. and Galas, J. 2006a. Distribution of benthic fauna in relation to environmental conditions in an inundated opencast sulphur mine (Piaseczno reservoir, Southern Poland). Aquat. Ecol. 40: 203-210.

Effenberger, M., Sailer, G., Townsend, C. R. and Matthaei, C. D. 2006a. Local disturbance history and habitat parameters influence the microdistribution of stream invertebrates. Freshwat. Biol. 51: 312-332.

Eggermont, H., Heiri, O. and Verschuren, D. 2006a. Fossil Chironomidae (Insecta: Diptera) as quantitative indicators of past salinity in African lakes. - Quatern. Sci. Rev. 25: 19661994.

Einarsson, Á., Gardarsson, A., Gíslason, G. M. and Gudbergsson, G. 2006a. Populations of ducks and trout of the River Laxá, Iceland, in relation to variation in food resources. Hydrobiologia 567: 183-194.

Ekrem, T. 2006a. A redescription of Neozavrelia cuneipennis (Edwards) comb. nov., with a checklist of Neozavrelia species of the world (Diptera: Chironomidae). - Zootaxa 1153: 116.

Elliott, J. M. 2006a. Prey switching in Rhyacophila dorsalis (Trichoptera) alters with larval instar. - Freshwat. Biol. 51: 913-924.

Erbaeva, E. A. and Safronov, G. P. 2006a. Distribution of zoobenthos in Lake Hövsgöl. In: Goulden, C. E., Sitnikova, T., Gelhaus, J. and Boldgiv, B. (eds.): The geology, biodiversity and ecology of Lake Hövsgöl (Mongolia), pp. 403-431. Backhuys Publs, Leiden.

Erbaeva, E. A., Kozhova, O. M. and Safronov, G. P. 2006a. The fauna of bottom invertebrates of Lake Hövsgöl. - In: Goulden, C. E., Sitnikova, T., Gelhaus, J. and Boldgiv, B. (eds.): The geology, biodiversity and ecology of Lake 
Hövsgöl (Mongolia), pp. 259-278. Backhuys Publs, Leiden.

Faria, M. S., Ré, A., Malcato, J., Silva, P. C. L. D., Pestana, J., Agra, A. R., Nogueira, A. J. A. and Soares, A. M. V. M. 2006a. Biological and functional responses of in situ bioassays with Chironomus riparius larvae to assess river water quality and contamination. - Sci. tot. Envir. 371: 125-137.

Ferrington, L. C. Jr. and Sæther, O. A. 2006a. Rhagosmittia and Trondia, two new genera of Orthocladiinae from Oceania and Australia (Diptera: Chironomidae). - Aquat. Insects 28: 243-250.

Fesl, C. and Humpesch, U. H. 2006a. Spatiotemporal variability of benthic macroinvertebrate community attributes and their relationship to environmental factors in a large river (Danube, Austria). - Arch. Hydrobiol. Suppl. 158, Large Rivers 16: 329359.

Fesl, C. and Humpesch, U. H. 2006b. Community organization of larval chironomid (Diptera) assemblages and environmental factors in a large river: prediction and validation of their interrelationships after three years. - Arch. Hydrobiol. Suppl. 158, Large Rivers 16: 495523.

Fink, P., Peters, L. and Elert, E. v. 2006a. Stoichiometric mismatch between littoral invertebrates and their periphyton food. Arch. Hydrobiol. 165: 145-165.

Finstad, A. G., Ugedal, O. and Berg, O. K. 2006a. Growing large in a low grade environment: size dependent foraging gain and niche shifts to cannibalism in Arctic char. - Oikos 112: 7382.

Flotemersch, J. E., Blocksom, K., Hutchens, J. J. Jr. and Autrey, B. C. 2006a. Development of a standardized large river bioassessment protocol (LR-BP) for macroinvertebrate assemblages. - River Res. Applics 22: 775790.

Francis, D. R., Wolfe, A. P., Walker, I. R. and Miller, G. H. 2006a. Interglacial and Holocene temperature reconstructions based on midge remains in sediments of two lakes from Baffin Island, Nunavut, Arctic Canada. Palaeogeogr. Palaeoclim. Palaeoecol. 236: 107-124.

Fritz, K. M. and Feminella, J. W. 2006a. Differential response of stream periphyton and invertebrate grazers to habitat modification by the emergent macrophyte Justicia americana. - Mar. Freshwat. Res. 57: 207-214.

Füreder, L., Ettinger, R., Boggero, A., Thaler, B. and Thies, H. 2006a. Macroinvertebrate diversity in Alpine lakes: effects of altitude and catchment properties. - Hydrobiologia 562: 123-144.

Furey, P. C., Nordin, R. N. and Mazumder, A. 2006a. Littoral benthic macroinvertebrates under contrasting drawdown in a reservoir and a natural lake. - J. N. Am. benthol. Soc. 25: 19-31.

Gandouin, E., Maasri, A., Van Vliet-Lanoë, B. and Franquet, E. 2006a. Chironomid (Insecta: Diptera) assemblages from a gradient of lotic and lentic waterbodies in river floodplains of France: a methodological tool for paleoecological applications. - J. Paleolimnol. 35: 149-166.

Gao, La. and Li, B. 2006a. A potential native natural enemy of invasive aquatic weed water hyacinth. - Biol. Invasions 8: 16891692.

Gathmann, F. O. and Williams, D. D. 2006a. Insect emergence in Canadian coldwater springs: spatial and temporal patterns, and species-environment relationships. - Annls Limnol. 42: 143-156.

Gerhardt, A., Orendt, C., Dettinger-Klemm, P. M. A., Janssens de Bisthoven, L., Michiels, S., Otto, C. J. und Vogt, C. 2006a. Chironomiden: Potential und Einsatzmöglichkeiten im Biomonitoring von Gewässern - ein Überblick. - DGL-Mitt. I/2006: 49-57.

Gido, K. B., Franssen, N. R. and Propst, D. L. 2006a. Spatial variation in $\delta^{15} \mathrm{~N}$ and $\delta^{13} \mathrm{C}$ isotopes in the San Juan River, New Mexico and Utah: implications for the conservation of native fishes. - Envir. Biol. Fishes 75: 197207.

Giłka, W. 2006a. Setny gatunek z plemienia Tanytarsini w polskiej faunie (Diptera: Chironomidae). (A hundredth species of the tribe Tanytarsini in the Polish fauna (Diptera: Chironomidae).) - Dipteron 22: 8-10.

Giłka, W. and Abramczuk, Ł. 2006a. Micropsectra davigra sp. n. from the Tatra Mountains - a contribution to the systematics of the Micropsectra attenuata species group (Diptera: Chironomidae). - Polskie Pismo ent. (= Pol. J. Ent.) 75: 39-44. 
Gillis, P. L., Reynoldson, T. B. and Dixon, D. G. 2006a. Metallothionein-like protein and tissue metal concentrations in invertebrates (oligochaetes and chironomids) collected from reference and metal contaminated field sediments. - J. Gt Lakes Res. 32: 565-577.

Goedkoop, W., Åkerblom, N. and Demandt, M. H. 2006a. Trophic fractionation of carbon and nitrogen stable isotopes in Chironomus riparius reared on food of aquatic and terrestrial origin. - Freshwat. Biol. 51: 878886.

Gonçalves, J. F. Jr., França, J. S., Medeiros, A. O., Rosa, C. A. and Callisto, M. 2006a. Leaf breakdown in a tropical stream. - Int. Rev. Hydrobiol. 91: 164-177.

Gray, D., Scarsbrook, M. R. and Harding, J. S. 206a. Spatial biodiversity patterns in a large New Zealand braided river. N. Z. Jl mar. Freshwat. Res. 40: 631-642.

Grayson, A. 2006a. New Yorkshire Chironomidae and Phoridae (Diptera). Yorkshire Naturalists Un. Bull. 45: 21-27.

Greathouse, E. A. and Pringle, C. M. 2006a. Does the river continuum concept apply on a tropical island? Longitudinal variation in a Puerto Rican stream. - Can. J. Fish. aquat. Sci. 63: 134-152.

Green, A. J. and Sanchez, M. I. 2006a. Passive internal dispersal of insect larvae by migratory birds. - Biol. Lett. 2: 55-57.

Grosell, M., Gerdes, R. M and Brix, K. V. 2006a. Chronic toxicity of lead to three freshwater invertebrates -- Brachionus calyciflorus, Chironomus tentans, and Lymnaea stagnalis. Envir. Toxic. Chem. 25: 97-104.

Grund, M. 2006a. Chironomidae (Diptera) in Dominican amber as indicators for ecosystem stability in the Caribbean. - Palaeogeogr. Palaeoclim. Palaeoecol. 241: 410-416.

Grzybkowska, M. 2006a. Jak przetrwać w skrajnie trudnych warunkach? Adaptacje ochotek (How to survive in extreme environments? Adaptations of chironomids). Kosmos 55: 197-207.

Haberle, S. G., Tibby, J., Dimitriadis, S. and Heijnis, H. 2006a. The impact of European occupation on terrestrial and aquatic ecosystem dynamics in an Australian tropical rain forests. J. Ecol. 94: 987-1002.

Hahn, S. and Reinhardt, K. 2006a. Habitat preference and reproductive traits in the
Antarctic midge Parochlus steinenii (Diptera: Chironomidae). - Antarct. Sci. 18: 175-181.

Hall, L. W. Jr., Killen. W. D. and Anderson, R. D. 2006a. Characterization of benthic communities and physical habitat in the Stanislaus, Tuolumne, and Merced Rivers, California. - Envir. Monit. Assess. 115: 223264.

Halpern, M., Raats, D., Lavion, R. and Mittler, S. 2006a. Dependent population dynamics between chironomids (nonbiting midges) and Vibrio cholerae. - FEMS [Fedn Eur. microbiol. Soc.] Microbiol. Ecol. 55: 98-104.

Hamer, G. L., Heske, E. J., Brawn, J. D. and Brown, P. W. 2006a. Migrant shorebird predation on benthic invertebrates along the Illinois River, Illinois. - Wilson J. Orn. 118: 152-163.

Hamerlík, L. 2006a. Pakomáre (Diptera: Chironomidae) olomouckých fontán. (Chironomids (Diptera: Chironomidae) of Olomouc fountains.) - In: Měkotová, J. a Štěrba, O. (eds.): Říční krajina 4 - River Landscape 4. Proc. Conf. Olomouc 2006: 6469.

Hamerlík, L. 2006b. Faunistic records of Chironomidae (Diptera) from the Morava river, new for Czech Republic. - Lauterbornia 58: 79-81.

Hamerlík, L., Šporka, F. and Zat'ovičová, Z. 2006a. Macroinvertebrates of inlets and outlets of the Tatra Mountain lakes (Slovakia). - Biologia, Bratisl. 61, Suppl. 18: S167-S179.

Hassell, K. L., Kefford, B. J. and Nugegoda, D. 2006a. Sub-lethal and chronic salinity tolerances of three freshwater insects: Cloeon sp. and Centroptilum sp. (Ephemeroptera: Baetidae) and Chironomus sp. (Diptera: Chironomidae). - J. exp. Biol. 209: 40244032.

Hayford, B. and Ferrington, L. C. Jr. 1006a. Distribution of Chironomidae (Diptera) in Lake Hövsgöl, Mongolia. - In: Goulden, C. E., Sitnikova, T., Gelhaus, J. and Boldgiv, B. (eds.): The geology, biodiversity and ecology of Lake Hövsgöl (Mongolia), pp. 433-452. Backhuys Publs, Leiden.

Hayford, B., Bachmann, J. and Gotov, M. 2006a. A comparison between communities of Chironomidae (Insecta: Diptera) from lake bays and affluent streams of the Lake Hovsgol watershed, Mongolia. - Proc. Acad. nat. Sci. Philad. 155: 13-23. 
Heegaard, E., Lotter, A. F. and Birks, H. J. B. 2006a.Aquatic biota and the detection of climate change: are there consistent aquatic ecotones? - J. Paleolimnol. 35: 507-518.

Heinrichs, M., Barnekow, L. and Rosenberg, S. 2006a. A comparison of chironomid biostratigraphy from Lake Vuolep Njakajaure with vegetation, lake-level, and climate changes in Abisko National Park, Sweden. - J. Paleolimnol. 36: 119-131.

Heinrichs, M. L. and Ian R. Walker, I. R. 2006a. Fossil midges and palaeosalinity: potential as indicators of hydrological balance and sealevel change. - Quatern. Sci. Rev. 25: 19481965.Helson, J. E., Williams, D. D. and Turner, D. 2006a. Larval chironomid community organization in four tropical rivers; human impacts and longitudinal zonation. - Hydrobiologia 559: 413-431.

Herder, F. and Freyhof, J. 2006a. Resource partitioning in a tropical stream fish assemblage. - J. Fish Biol. 69: 571-589.

Hershey, A. E., Beaty, S., Fortino, K., Kelly, S., Keyse, M., Luecke, C., O'Brien, W. J. and Whalen, S. C. 2006a. Stable isotope signatures of benthic invertebrates in arctic lakes indicate limited coupling to pelagic production. - Limnol. Oceanogr. 51: 177-188.

Hirabayashi, K., Yoshizawa, K., Ariizumi, K., Yoshida, N. and Kazama, F. 2006a. Longterm dynamics of benthic macroinvertebrates from a small shallow lake in central Japan. Verh. int. Verein. Limnol. 29: 1741-1746.

Hirvenoja, M., Palmén, E. and Hirvenoja, E. 2006a. The emergence of Halocladius variabilis (Staeger) (Diptera: Chironomidae) in the surroundings of the Tvärminne Biological Station in the northern Baltic Sea. Ent. fenn. 17: 87-89.

Hobbs, M. S., Grippo, R. S., Farris, J. L., Griffin, B. R. and Harding, L. L. 2006a. Comparative acute toxicity of potassium permanganate to nontarget aquatic organisms. - Envir. Toxic. Chem. 25: 3046-3052.

Horecký, J., Stuchlík, E., Chvojka, E. P., Hardekopf, D. W., Mihaljevič, M. and Špaček; J. 2006a. Macroinvertebrate community and chemistry of the most atmospherically acidified streams in the Czech Republic. - Wat. Air Soil Pollut. 173: 261-272.

Howard, J. K. and Cuffey, K. M. 2006a. The functional role of native freshwater mussels in the fluvial benthic environment. - Freshwat. Biol. 51: 460-474.

Hoxmeier, R. J. H., Wahl, D. H., Brooks, R. C. and Heidinger, R. C. 2006a. Growth and survival of age-0 walleye (Sander vitreus): interactions among walleye size, prey availability, predation, and abiotic factors. Can. J. Fish. aquat. Sci. 63: 2173-2182.

Hulsey, C. D., Marks, J., Hedrickson; D. A., Williamson, C. A., Cohen, A. E. and Stephens, M. J. 2006a. Feeding specialization in Herichthys minckleyi: a trophically polymorphic fish. - J. Fish Biol. 68: 13991410.

Hurst, T. P., Kay, B. H., Brown, M. D. and Ryan, P. A. 2006a. Laboratory evaluation of the effect of alternative prey and vegetation on predation of Culex annulirostris immatures by Australian native fish species. - J. Am. Mosquito Control Ass. 22: 412-417.

Ilyashuk, B. P., Andreev, A. A., Bobrov, A. A., Tumskoy, V. E. and Ilyashuk, E. A. 2006a. Interglacial history of a palaeo-lake and regional environment: a multi-proxy study of a permafrost deposit from Bol'shoy Lyakhovsky Island, Arctic Siberia. - J. Paleolimnol. 35: 855-872.

Ingvason, H. R., Olafsson, J. S., Gardarsson, A. and Jonsdottir, R. 2006a. Diapause and fat condition of Tanytarsus gracilentus larvae in a sub-arctzic lake. - Verh. int. Verein. theor. angew. Limnol. 29: 1316-1320.

Inoue, M. and Miyayoshi, M. 2006a. Fish foraging effects on benthic assemblages along a warm-temperate stream: differences among drift feeders, benthic predators and grazers. Oikos 114: 95-107.

Ishijima, C., Taguchi, A., Takagi, M., Motobayashi, T., Nakai, M. and Kunimi, Y. 2006a. Observational evidence that the diet of wolf spiders (Araneae: Lycosidae) in paddies temporarily depends on dipterous insects. Appl. Ent. Zool. 41: 195-200.

Jackson, J. K. and Füreder, L. 2006a. Long-term studies of freshwater macroinvertebrates: a review of the frequency, duration and ecological significance. - Freshwat. Biol. 51: 591-603.

Jin, L., Luo, J., Fu, Y. and Xu, S. 2006a. Prey and feeding behavior of larval Culex (Lutzia) fuscanus (Diptera: Culicidae) in Shantou, Guangdong Province, China. - J. med. Ent. 43: 785-786. 
Johnson, B. R., Wallace, J. B., Rosemond, A. D. and Cross, W. F. 2006a. Larval salamander growth responds to enrichment of a nutrient poor headwater stream. - Hydrobiologia 573: 227-232.

Jovic, A., Paunovic, M., Stojanovic, B., Milošević, S. and Nikoli, V. 2006a. Aquatic invertebrates of the Ribnica and Lepenica Rivers: composition of the community and water quality. - Archs biol. Sci. 58: 115-119.

Kagalou, I., Economidis, G., Leonardos, I. and Papaloukas, C. 2006a. Assessment of a Mediterranean shallow lentic ecosystem (Lake Pamvotis, Greece) using benthic community diversity: Response to environmental parameters. - Limnologica 36: 269-278.

Kaller, M. D. and Kelso, W. E. 2006a. Short-term decompositional state does not influence use of wood by macroinvertebrates in subtropical, coastal plain streams. - Hydrobiologia 571: 157-167.

Karimi, R. and Folt, C. L. 2006a. Beyond macronutrients: element variability and multielement stoichiometry in freshwater invertebrates. - Ecol. Lett. 9: 1273-1283.

Katunzi, E. F. B., Van Densen, W. L. T., Wanink, J. H. and Witte, F. 2006a. Spatial and seasonal patterns in the feeding habits of juvenile Lates niloticus (L.), in the Mwanza Gulf of Lake Victoria. - Hydrobiologia 568:121-133.

Kawai, K., Adachi, Y., Imabayashi, H. 2006a. A rearing experiment of Chironomus yoshimatsui (Diptera: Chironomidae). - Med. Ent. Zool. 57: 125-129.

Kefford, B. J., Nugegoda, D., Metzeling, L. and Fields, E. J. 2006a. Validating species sensitivity distributions using salinity tolerance of riverine macroinvertebrates in the southern Murray-Darling Basin (Victoria, Australia). - Can. J. Fiash. aquat. Sci. 63: 1865-1877.

Kennedy, B. M., Thompson, B. W. and Luecke, C. 2006a. Ecological differences between two closely related morphologically similar benthic whitefish (Prosopium spilonotus and Prosopium abyssicola) in an endemic whitefish complex. - Can. J. Fish. aquat. Sci. 63: 1700-1709.

Khanna, P., Sharma, O. P. and Tripathi, N. K. 2006a. Genotoxic effect of hydrogen peroxide on polytene chromosomes of Chironomus samoensis Edwards (Chironomidae: Diptera).
- Proc. natn. Acad. Sci. India, Sect. B, biol. Sci. 76: 41-50.

Khatami, S. H. and Shayegan, S. J. 2006a. Physico-chemical and biological characteristics of sarabs (spring pools) in the Kermanshah Province of Iran. - Iran. J. Sci. Technol., Trans. B: Engng 30: 621-635.

Kikawada, T., Nakahara, Y., Kanamori, Y., Iwata, K., Watanabe, M., McGee, B., Tunnacliffe, A. and Okuda, T. 2006a. Dehydration-induced expression of LEA proteins in an anhydrobiotic chironomid. Biochem. biophys. Res. Communs 348: 56-61.

Kiknadze, I. I., Michalova, P., Istomina, A. G., Golygina, V. V., Int Panis, L. and Krastanov, B. 2006a. (The chromosomal polymorphism and divergence of populations in Chironomus nuditarsis Str. (Diptera, Chironomidae).) Tsitologiya 48: 595-609.

Kim, C. K., Kwak, I. S., Cha, E. Y. and Chon, T. S. 2006a. Implementation of wavelets and artificial neural networks to detection of toxic response behavior of chironomids (Chironomidae: Diptera) for water quality monitoring. - Ecol. Modell. 195: 61-71.

Kim, M. C., Park, J. H. and Han, S. S. 2006a. Ecological synopsis for Chironomus flaviplumus (Diptera: Chironomidae) in the Jung-rang stream. - Ent. Res. 36: 85-93.

Kiss, O., Nagy, K. és Solcz, R. 2006a. Északmagyarországi vízfolyások gerinctelen makrofaunájáról. (On the macroinvertebrate fauna of watercourses in northern Hungary.) Hidrol. Közl. 86: 63-65.

Knudsen, R., Klemetsen, A., Amundsen, P.-A. and Hermansen, B. 2006a. Incipient speciation through niche expansion: an example from the Arctic charr in a subarctic lake.. - Proc. R. Soc. B, biol. Sci. 273: 22912298.

Köster, D. and Pienitz, R. 2006a. Late-Holocene environmental history of two New England ponds: natural dynamics versus human impacts. - Holocene 16: 519-532.

Kouamé, M. K., Ouattara, A., Dietoa, M. Y. et Gourène, G. 2006a. Alimentation du Clupeidae Pellonula leonensis dans le lac de barrage de Buyo (Côte d'Ivoire). - Cybium 30: 145-150.

Kouamelan, E. P., Kone, T., N'Douba, V. and Ollevier, F. 2006a. Food habits and trophic resource partitioning among three mormyrid 
fishes from man-made Lake Ayame, Ivory Coast. - Afr. Zool. 41: 266-274.

Kratzer, E. B., Jackson, J. K., Arscott, D. B., Aufdenkampe, A. K., Dow, C. L., Kaplan, L. A., Newbold, J. D. and Sweeney, B. W. 2006a. Macroinvertebrate distribution in relation to land use and water chemistry in New York City drinking-water-supply watersheds. - J. N. Am. benthol. Soc. 25: 954976.

Kravtsova, L. S., Weinberg, I. V., Khanaev, I. V., Sherbakov, D. Yu., Semovsky, S. V., Adov, F. V., Rozhkova, N. A., Pomazkina, G. V., Shevelyova, N. G. and Kaygorodova, I. A. 2006a. The formation of a fouling community on artificial substrate in Lake Baikal. Hydrobiologia 568, Suppl. 1: 51-55.

Krno, I., Šporka, F., Galas, J., Hamerlík, L., Zat'ovičová, Z. and Bitušík, P. 2006a. Littoral benthic macroinvertebrates of mountain lakes in the Tatra Mountains (Slovakia, Poland). Biologia, Bratisl. 61, Suppl. 18: S147-S166.

Kubovčík, V. and Beták, M. 2006a. Subfosylne ochotkowate (Diptera: Chironomidae) jeziora Ladové pleso (Tatry Wysokie, Słowacja). (Subfossil chironomids (Diptera: Chironomidae) from lake Ladové pleso (the High Tatra Mts., Slovakia).) - Dipteron 22: 28-29.

Kubovčík, V. and Beták, M. 2006b. Historia wysokogórskiego jeziora Ladové pleso (Tatry Wysokie, Słowacja) ostatnich 400 lat. (Environmental history of an alpine lake Ladové pleso (the High Tatra Mts, Slovakia), during the last 400 years.) - Dipteron 22: 3031.

Kubovčík, V. and Bitušík, P. 2006a. Subfossil chironomids (Diptera, Chironomidae) in three Tatra Mountain lakes (Slovakia) on an acidification gradient. - Biologia, Bratisl. 61, Suppl. 18: S213-S220.

Kupfer, A., Langel, R., Scheu, S., Himstedt, W. and Maraun, M. 2006a. Trophic ecology of a tropical aquatic and terrestrial food web: insights from stable isotopes $\left({ }^{15} \mathrm{~N}\right)$. - J. trop. Ecol. 22: 469-476.

Langdon, P. G., Ruiz, Z., Brodersen, K. P. and Foster, I. D. L. 2006a. Assessing lake eutrophication using chironomids: understanding the nature of community response in different lake types. - Freshwat. Biol. 51: 562-577.

Langton, P. H. and Ruse, L. P. 2006a. Further species of Chironomidae (Diptera) new to the
British Isles and data for species newly recorded in the 1998 Checklist. - Dipterists Dig., $2^{\text {nd }}$ Ser. 12: 135-140.

Laroque, I., Pienitz, R. and Rolland, N. 2006a. Factors influencing the distribution of chironomids in lakes distributed along a latitudinal gradient in northwestern Quebec, Canada. - Can. J. Fish. aquat. Sci. 63: 12861297.

Lauringson, V. and Kotta; J. 2006a. Influence of the thin drift algal mats on the distribution of macrozoobenthos in Kõiguste Bay, NE Baltic Sea. - Hydrobiologia 554: 97-105.

Lazzara, M., Lencioni, V. e Maiolini, B. 2006a. I microinvertebrati. - In: Cantonati, M. e Lazzara, M. (eds.): I laghi di alta montagna del bacino del Fiume Avisio (Trentino orientale). Monongr. Mus. trident. Sci. nat. 3: 185-207.

Lecerf, A., Usseglio-Polatera, P., Charcosset, J.Y., Lambrigot, D., Bracht, B. and Chauvet, E. 2006a. Assessment of functional integrity of eutrophic streams using litter breakdown and benthic macroinvertebrates. - Arch. Hydrobiol. 165: 105-126.

Ledger, M. E., Harris, R. M. L., Milner, A. M. and Armitage, P. D. 2006a. Disturbance, biological legacies and community development in stream mesocosms. Oecologia 148: 682-691.

Lee, C. and Wall, R. 2006a. Distribution and abundance of insects colonizing cattle dung in South West England. - J. nat. Hist. 40: 11671177.

Lee, R. E. Jr., Elnitsky, M. A., Rinehart, J. P., Hayward, S. A., Sandro, L. H. and Denlinger, D. L. 2006a. Rapid cold-hardening increases the freezing tolerance of the Antarctic midge Belgica antarctica. - J. exp. Biol. 209: 399406.

Lee, S. B. and Choi, J. 2006a. Multilevel evaluation of nonylphenol toxicity in fourthinstar larvae of Chironomus riparius (Diptera, Chironomidae). - Envir. Toxic. Chem. 25: 3006-3014.

Lee, S.-M., Lee, S.-B., Park, C.-H. and Choi, J. 2006a. Expression of heat shock protein and hemoglobin genes in Chironomus tentans (Diptera, chironomidae [sic!]) larvae exposed to various environmental pollutants: A potential biomarker of freshwater monitoring. - Chemosphere 65: 1074-1081. 
Lee, S. E., Yoo, D. H., Son, J. and Cho, K. 2006a. Proteomic evaluation of cadmium toxicity on the midge Chironomus riparius Meigen larvae. - Proteomics 6: 945-957.

Lencioni, V. e Lazzara, M. (2004) 2006a. I chironomidi subfossili (Diptera, Chironomidae) del Lago di Tovel (Trentino, Alpi centro-orientali): uno sguardo agli ultimi 400 anni. - Studi trent. Sci. nat., Acta biol., 81, Suppl. 2: 155-165.

Leppänen, M. T., Ristola, T., Johnson, J. and Burton, G. A. Jr. 2006a. Applying adult emergence as an endpoint in a post-exposure laboratory test using two midge species (Diptera: Chironomidae). - Chemosphere 64: 1667-1674.

Lessart, J. L. and Merritt, R. W. 2006a. Influence of marine-derived nutrients from spawning salmon on aquatic insect communities in southeast Alaskan streams. - Oikos 113: 334343.

Liebherr, J. K. and Short, A. E. Z. 2006a. Blackburnia riparia, new species (Coleoptera: Carabidae, Platynini): a novel element in the Hawaiian riparian insect fauna. - Jl N. Y. ent. Soc. 114: 1-16.

Liu, X.-Q., Wang, H.-Z. and Liang, X.-M. 2006a. Food web of macroinvertebrate community in a Yangtze shallow lake: trophic basis and pathways. - Hydrobiologia 571: 283-295.

Liu, Y. D. and Wang, X. H. 2006a. Tokunagaia Sæther from China (Diptera: Chironomidae: Orthocladiinae). - Zootaxa 1183: 43-56.

Locklin, J. L., Arsuffi, T. L. and Bowles, D. E. 2006a. Life history of Sialis (Megaloptera: Sialidae) in a lentic and lotic ecosystem in central Texas. - Am. Midl. Nat. 155: 50-62.

Löhr, A. J., Sluik, R., Olaveson, M. M., Ivorra, N., Van Gestel, C. A.M. and Van Straalen, N. M. 2006a. Macroinvertebrate and algal communities in an extremely acidic river and the Kawah Ijen crater lake $(\mathrm{pH}<0.3)$, Indonesia. - Arch. Hydrobiol. 165: 1-21.

Longcore, J. R., McAuley, D. G., Pendelton, G. W., Bennatti, C. R., Mingo, T. M. and Stromborg, K. L. 2006a. Macroinvertebrate abundance, water chemistry, and wetland characteristics affect use of wetlands by avian species in Maine. - Hydrobiologia 567: 143167.

Lotter, A. F., Heiri, O., Hofmann, W., van der Knaap, W. O., van Leeuwen, J. F. N., Walker, I. R. and Wick, L. 2006a. Holocene timber- line dynamics at Bachalpsee, a lake at $2265 \mathrm{~m}$ a.s.l. in the northern Swiss Alps. - Veget. Hist. Archaeobot. 15: 295-307.

MacDonald, E. E. and Taylor, B. R. 2006a. Incidence of mentum deformities in midge larvae (Diptera: Chironomidae) from northern Nova Scotia, Canada. - Hydrobiologia 563: 277-287.

Mac Nally, R., Lloyd, N. J. and Lake, P. S. 2006a. Comparing patterns of spatial autocorrelation of assemblages of benthic invertebrates in upland rivers in south-eastern Australia. - Hydrobiologia 571: 147-156.

Mäenpää, K. and Kukkonen, J. V. K. 2006a. Bioaccumulation and toxicity of 4nonylphenol (4-NP) and 4-(2-dodecyl)benzene sulfonate (LAS) in Lumbriculus variegatus (Oligochaeta) and Chironomus riparius (Insecta). - Aquat. Toxic. 77: 329338.

Magnusson, A. K. and Williams, D. D. 2006a. The roles of natural temporal and spatial variation versus biotic influences in shaping the physicochemical environment of intermittent ponds: a case study. - Arch. Hydrobiol. 165: 537-556.

Magny, M., Aalbersberg, G., Bégeot, C., BenoitRuffaldi, P., Bossuet, G., Disnar, J.-R., Heiri, O., Laggoun-Defarge, F., Mazier, F., Millet, L., Peyron, O., Vannière, B. and WalterSimonnet, A.-V. 2006a. Environmental and climatic changes in the Jura mountains (eastern France) during the LateglacialHolocene transition: a multi-proxy record from Lake Lautrey. - Quatern. Sci. Rev. 25: 414-445.

Mailman, M. and Bodaly, R. A.2006a. The burning question: Does burning before flooding lower methyl mercury production and bioaccumulation? - Sci. tot. Envir. 368: 407-417.

Maiolini, B., Lencioni, V., Boggero, A., Thaler, B., Lotter, A. F. and Rossaro, B. 2006a. Zoobenthic communities of inlets and outlets of high altitude Alpine lakes. - Hydrobiologia 562: 217-229.

Makarchenko, E. A. and Makarchenko, M. A. 2006a. Three new species of chironomids (Diptera: Chironomidae: Orthocladiinae) from the Russian Far East. - Russ. ent. J. 15: 73-77.

Makarchenko, E. A. i Makarchenko, M. A. 2006b. Novye i maloizvestnyi vidy khironomid podsemeistva Orthocladiinae 
(Diptera: Chironomidae) s rossiiskogo Dal'nego Vostoka. (New or little-known chironomids of Orthocladiinae (Diptera: Chironomidae) from the Russian Far East.) Russ. ent. J. 15: 83-92.

Makarchenko, E. A. i Makarchenko, M. A. 2006c. Novye vidy khironomid roda Orthocladius van der Wulp, 1874 (Diptera, Chironomidae) s rossiiskogo Dal'nego Vostoka. (A new species of Orthocladius van der Wulp, 1874 (Diptera, Chironomidae) of the Russian Far East.) - Evraziat. ent. Zh. (=Euroas. ent. J.) 5: 57-67.

Makarchenko, E. A. i Makarchenko, M. A. 2006d. Khironomidy rodov Corynoneura Winnertz, 1846 i Thienemanniella Kieffer, 1919 (Diptera, Chironomidae, Orthocladiinae) rossiiskogo Dal'nego Vostoka. (Chironomids of the genera Corynoneura Winnertz, 1846 and Thienemanniella Kieffer, 1919 (Diptera, Chironomidae, Orthocladiinae) of the Russian Far East.) - Evraziat. ent. Zh. (=Euroas. ent. J.) 5: 151-162.

Makarchenko, E. A. i Makarchenko, M. A. 2006e. Chaetocladius (s. str.) amurensis sp. n. (Diptera, Chironomidae, Orthocladiinae) from the Amur River basin (Russian far East). Evraziat. ent. Zh. (=Euroas. ent. J.) 5: 276277.

Makarchenko, E. A., Makarchenko, M. A. i Zorina, O, V. 2006a. Fauna khironomid (Diptera, Chironomidae) ostrova Moneron. (Chironomid fauna (Diptera, Chironomidae) of Moneron Island.) - In: Bogatov, V. V., Barkalov, V. Yu., Lelei, A. S., Makarchenko, E. A. i Storozhenko, S. Yu. (eds.): Rastitel'nyi i zhivotnyi mir ostrova Moneron (Materialy Mezhdunarodnogo sakhalinskogo proekta) (Flora and fauna of Moneron Island (Materials of International Sakhalin Project), pp. 268-274. Dal'nauka, Vladivostok.

Makarieva, A. M., Gorshkov, V. G., Li, B.-L. and Chown, S. L. 2006a. Size- and temperatureindependence of minimum life-supporting metabolic rates. - Funct. Ecol. 20: 83-96.

Maloney, K. O. and Feminella, J. W. 2006a. Evaluation of single- and multi-metric benthic macroinvertebrate indicators of catchment disturbance over time at the Fort Benning Military Installation, Georgia, USA. - Ecol. Indic. 6: 469-484.

Man'ko, V. V. 2006a. (Methodological approaches to investigation of $\mathrm{Na}^{+}-\mathrm{Ca}^{2+}$ exchange in exocrine secretory cells.) Ukrain. biokhim. Zh. 78:43-62.

Marshall, J. C., Sheldon, F., Thoms, M. and Choy, S. 2006a. The macroinvertebrate fauna of an Australian dryland river: spatial and temporal patterns and environmental relationships. - Mar. Freshwat. Res. 57: 6174.

Marshall, J. C., Steward, A. L. and Harch, B. D. 2006a. Taxonomic resolution and quantification of freshwater macroinvertebrate samples from an Australian dryland river: the benefits and costs of using species abundance data. - Hydrobiologia 572: 171-194.

Marti, G. A., Azpelicueta, M. M., Tranchida, M. C., Pelizza, S. A. and García, J. J. 2006a. Predation efficiency of indigenous larvivorous fish species on Culex pipiens L. larvae (Diptera: Culicidae) in drainage ditches in Argentina. - J. Vector Ecol. 31: 102-106.

Martin, J., Andreeva, E. N., Kiknadze, I. I. and Wülker, W. F. 2006a. Polytene chromosomes and phylogenetic relationships of Chironomus atrella (Diptera: Chironomidae) in North America. - Genome 49: 1384-1392.

Martin, P. and Stur, E. 2006a. Parasite-host associations and life cycles of spring-living water mites (Hydrachnidia, Acari) from Luxembourg. - Hydrobiologia 573: 17-37.

Martinez, E. A., Wold, L., Moore, B. C., Schaumloffel, J. and Dasgupta, N. 2006a. Morphologic and growth responses in Chironomus tentans to arsenic exposure. Archs envir. Contam. Toxic. 51: 529-536.

Martínez-Bastida, J. J., Arauzo, M. y Valladolid, M. 2006a. Diagnóstico de la calidad ambiental del río Oja (La Rioja, España) mediante el análisis de la comunidad de macroinvertebrados bentónicos. - Limnetica 25: 733-744.

Martinovic-Vitanovic, V., Jakovcev-Todorovic, D. and Kalafatic, V. 2006a. Qualitative study of the bottom fauna of the River Danube (river kilometre 1433-845,6), with special emphasis on the oligochaetes. - Arch. Hydrobiol. Suppl. 158, Large Rivers 16: 427452.

Marziali, L., Lencioni, V. and Rossaro, B. 2006a. Chironomid species as indicators of freshwater habitat quality. - Verh. int. Verein.Limnol. 29: 1553-1555.

Marziali, L., Lencioni, V. and Rossaro, B. 2006b. Adaptations of pupae of Chironomidae 
(Insecta: Diptera) to oxygen-poor habitats. Pol. J. Ecol. 54: 687-693.

Maul, J. D., Belden, J. B., Schwab, B. A., Whiles, M. R., Spears, B., Farris, J. L. and Lydy, M. J. 2006a. Bioaccumulation and trophic transfer of polychlorinated biphenyls by aquatic and terrestrial insects to tree swallows (Tachycineta bicolor). - Envir. Toxic. Chem. 25: 1017-1025.

McCabe, D. J., Beekey, M. A., Mazloff, A. and Marsden, J. E. 2006a. Negative effect of zebra mussels on foraging and habitat use by lake sturgeon (Acipenser fulvescens). - Aquat. Conserv. mar. Freshwat. Ecosyst. 16: 493500.

McCarthy, J. M., Hein, C. L., Olden, J. D. and Vander Zanden, M. J. 2006a. Coupling longterm studies with meta-analysis to investigate impacts of non-native crayfish on zoobenthic communities. - Freshwat. Biol. 51: 224-235.

McDowall, R. M. 2006a. Making a living in Red Pond: A snapshot of the diet of a population of Aplochiton zebra (Teleostei: Galaxiidae) at the Falkland Islands. - N. Z. Jl Zool. 32: 2327.

McKay, S. F. and King, A. J. 2006a. Potential ecological effects of water extraction in small, unregulated streams. - River Res. Applics 22: 1023-1037.

McKie, B. G. and Pearson, R. G. 2006a. Environmental variation and the predator-specific responses of tropical stream insects: effects of temperature and predation on survival and development of Australian Chironomidae (Diptera). - Oecologia 149: 328-339.

McLachlan, A. J. 2006a. You are looking mitey fine: parasites as direct indicators of fitness in the mating system of a host species. - Ethol. Ecol. Evol. 18: 233-239.

Meier, R. Shiyang, K.,Vaidya, G. and Ng, P. 2006a. DNA barcoding and taxonomy in Diptera: a tale of high hintraspecific variability and low identification success. Syst. Biol. 55: 715-728.

Meissner, K. and Muotka, T. 2006a. The role of trout in stream food webs: integrating evidence from field surveys and experiments. - J. Anim. Ecol. 75: 421-433.

Mermillod-Blondin, F. and Rosenberg, R. 2006a. Ecosystem engineering: the impact of bioturbation on biogeochemical processes in marine and freshwater benthic habitats. Aquat. Sci. 68: 434-442.
Michailova, P., Petrova, N., Ilkova, J., Bovero, S., Brunetti, S., White, K. and Sella, G. 2006a. Genotoxic effect of copper on salivary gland polytene chromosomes of Chironomus riparius Meigen 1804 (Diptera, Chironomidae). - Envir. Pollut. 144: 647-654.

Miliša, M., Matoniškin Kepčija, R., Radanović, I., Ostojić, A. and Habdija, I. 2006a. The impact of aquatic macrophyte (Salix sp. and Cladium mariscus (L.) Pohl.) removal on habitat conditions and macroinvertebrates of tufa barriers (Plitvice Lakes, Croatia). Hydrobiologia 573: 183-197.

Miller, S. A. and Crowl, T. A. 2006a. Effects of common carp (Cyprinus carpio) on macrophytes and invertebrate communities in a shallow lake. - Freshwat. Biol. 51: 85-94.

Milner, A. M., Conn, S. C. and Brown, L. E. 2006a. Persistence and stability of macroinvertebrate communities in streams of Denali National Park, Alaska: implications for biological monitoring. - Freshwat. Biol. 51: 373-387.

Montalto, L. and Paggi, A. C. 2006a. Diversity of chironomid larvae in a marginal fluvial wetland of the Middle Paraná River floodplain, Argentina. - Annls Limnol. 42: 289-300.

Montori, A., Tierno de Figueroa, J. M. and Santos, X. 2006a. The diet of the brown trout Salmo trutta (L.) during the reproductive period: size-related and sexual effects. - Int. Rev. Hydrobiol. 91: 438-450.

Moreno, P. and Callisto, M. 2006a. Benthic macroinvertebrates in the watershed of an urban reservoir in southeastern Brazil. Hydrobiologia 560: 311-321.

Mori, N. and Brancelj, A. 2006a. Macroinvertebrate communities of karst springs of two river catchments in the Southern Limestone Alps (the Julian Alps, NW Slovenia). - Aquat. Ecol. 40: 69-83.

Mormul, R. P., Vieira, L. A., Pressinatte Júnior, S., Monkolski, A. e dos Santos, A. M. 2006a Sucessão de invertebrados durante o processo de decomposição de duas plantas aquáticas (Eichhornia azurea e Polygonum ferrugineum). - Acta Scient. biol. Sci. 28: 109115.

Morozova, E. E. 2006a. Sistematika, morfologiya i ekologiya khironomid roda Cryptochironomus basseina Volgogradskogo vodokhranilishcha. (Systematics, morphology and 
ecology of chironomids of the genus Cryptochironomus of the Volgograd Reservoir basin.) - Avtoref. Diss. Dokt. biol. Nauk, Petrozavodsk. 41 pp.

Muenz, T. K., Golladay, S. W., Vellidis, G. and Smith, L. L. 2006a. Stream buffer effectiveness in an agriculturally influenced area, southwestern Georgia: responses of water quality, macroinvertebrates, and amphibians. J. envir. Qual. 35: 1924-1938.

Murza, G. L., Heaver, J. R. and Davis, A. R. 2006a. Minor pollinator-prey conflict in the carnivorous plant, Drosera anglica. - Pl. Ecol. 184: 43-52.

Myszkowski, L., Kamiński, R. and Kamler, E. 2006a. Compensatory growth and matter or energy deposition in Vimba vimba juveniles fed natural food or a formulated diet. - Folia zool. 55: 211-222.

Naik, D. G., Babrekar, A. A. and Nath, B., B. 2006a. 'Pheromone-like' compounds in the cuticle of aquatic Chironomus larva. - Chem. Ecol. 22: 501-508.

Nakano, D. and Nakamura, F. 2006a. Responses of macroinvertebrate communities to river restoration in a channelized segment of the Shibetsu River, Northern Japan. - River Res. Applic. 22: 681-689.

Nashchekin, D., Zhao, J., Visa, N. and Daneholt, B. 2006a. A novel Ded1-like RNA helicase interacts with the Y-box protein ctYB-1 in nuclear mRNP particles and in polysomes. - $J$. biol. Chem. 281: 14263-14272.

Newall, P., Bate, N. and Metzeling, L. 2006a. A comparison of diatom and macroinvertebrate classification of sites in the Kiewa River system, Australia. - Hydrobiologia 572: 131149.

Ngai, J. T. and Srivastava, D. S. 2006a. Predators accelerate nutrient cycling in a bromeliad ecosystem. - Science, Wash. 314: 963.

Nichols, S. J. and Norris, R. H. 2006a. River condition assessment may depend on the subsampling method: field live-sort versus laboratory sub-sampling of invertebrates for bioassessment. - Hydrobiologia 572: 195-213.

Nichols, S., Norris, R., Maher, W. and Thoms, M. 2006a. Ecological effects of serial impoundment on the Cotter River, Australia. Hydrobiologia 572: 255-273.

Nicolaidou, A., Petrou, K., Kormas, K. A. and Reizopoulou, S. 2006a. Inter-annual variability of soft bottom macrofaunal communities in two Ionian Sea lagoons. Hydrobiologia 555: 89-98.

Nilo, P., Tremblay, S., Bolon, A., Dodson, J., Dumont, P. and Fortin, R. 2006a. Feeding ecology of juvenile lake sturgeon in the St. Lawrence River system. - Trans. Am. Fish. Soc. 135: 1044-1055.

Nislow, K. H. and Lowe, W. H. 2006a. Influences of logging history and riparian forest characteristics on macroinvertebrates and brook trout (Salvelinus fontinalis) in headwater streams (New Hampshire, U.S.A.). - Freshwat. Biol. 51: 388-397.

Nogaro, G., Mermillod-Blondin, F., FrançoisCarcaillet, F., Gaudet, J.-P., Lafont, M. and Gibert, J. 2006a. Invertebrate bioturbation can reduce the clogging of sediment: an experimental study using infiltration sediment columns. - Freshwat. Biol. 51: 1458-1473.

Norberg-King, T. J., Sibley, P. K., Burton, G A., Ingersoll, C. G., Kemble, N. E., Ireland, S., Mount, D. R. and Rowland, C. D. 2006a. Interlaboratory evaluation of Hyalella azteca and Chironomus tentans short-term and longterm sediment toxicity tests. - Envir. Toxic. Chem. 25: 2662-2674.

Nosek, J. és Oertel, N. 2006a. A magyar Duna szakaszjellege a makroszkópikus gerinctelen társulások alapján. (Section types in the Hungarian reach of River Danube according to the macroinvertebrate communities.) - Acta biol. debrec., Suppl. oecol. hung. 14: 175-184.

Nowak, C., Hankeln, T., Schmidt, E. R. and Schwenk, K. 2006a. Development and localization of microsatellite markers for the sibling species Chironomus riparius and Chironomus piger (Diptera: Chironomidae). Molec. Ecol. Notes 6: 915-917.

Ntengwe, F. W. 2006a. Pollutant loads and water quality in streams of heavily populated and industrialised towns. - Phys. Chem. Earth, Pt A/B/C 31: 832-839.

Özkan, N. 2006a. The larval Chironomidae (Diptera) fauna of Bozcaada (Tenedos). - $G$. U. [= Gazi Univ.] Jl Sci. 19: 57-67.

Özkan, N. 2006b. The larval Chironomidae (Diptera) fauna of Gökçeada (Imbroz). - G. U. [= Gazi Univ.] Jl Sci. 19: 69-75.

Özkan, N. 2006c. Trakya Bölgesi (K rklareli, Tekirdağ, İstanbul ve Çanakkale) Chironomid (Chironomidae; Diptera) Faunas . (Fauna of chironomids (Chironomidae; Diptera) in 
Turkish Thrace Region (K rklareli, Tekirdağ, İstanbul and Çanakkale).) - Su Ürünleri Derg. 23: $125-132$.

Ozkan [= Özkan], N. and Camur-Elipek, B. 2006a. The dynamics of Chironomidae larvae (Diptera) and the water quality in Meric River (Edirne/Turkey). - Tiscia 35: 49-54.

Ohtaka, A., Nishino, M. and Kobayashi, T. 2006a. Disappearance of deep profundal zoobenthos in Lake Ikeda, southern Kyushu, Japan, with relation to recent environmental changes in the lake. - Limnology 7: 237-242.

Oliveira, C. S. N. and Fonseca-Gessner, A. A. 2006a New species of Ablabesmyia Johannsen (Diptera, Chironomidae, Tanypodinae) from the Neotropical Region, with description of male adults and immature stages. - Revta bras. Zool. 23: 740-745.

Olomukoro, J. O. and Nduh Tochukwu, O. C. 2006a. Macro-invertebrate colonization of artificial substrata II: weeds and plant stems. Asian J. Pl. Sci. 5: 990-995.

Olsson, K., Stenroth, P., Nyström, P., Holmqvist, N., McIntosh, A. R. and Winterbourn, M. J. 2006a. Does natural acidity mediate interactions between introduced brown trout, native fish, crayfish and other invertebrates in West Coast New Zealand streams? - Biol. Conserv. 130: 255-267.

Ormerod, S. J., Lewis, B. R., Kowalik, R. A., Murphy, J. F. and Davy-Bowker, J. 2006a. Field testing the AWIC index for detecting acidification in British streams. - Arch. Hydrobiol. 166: 99-115.

Orr, P. L., Guiguer, K. R. and Russel, C. K. 2006a. Food chain transfer of selenium in lentic and lotic habitats of a western Canadian watershed. - Ecotoxic. envir. Saf. 63: 175-188.

Ortiz, J. D., Martí, E. and Puig, M. A. 2006a. Influences of a point source on the microhabitat distribution of stream benthic macroinvertebrates. - Arch. Hydrobiol. 165: 469-491.

Oscoz, J. y Escala, M. C. 2006a. Efecto de la contaminación y la regulación del caudal sobre la comunidad de macroinvertebrados bentónicos del tramo bajo del río Larraun (norte de España). - Ecología 20: 245-258.

Oscoz, J., Campos, F. y Escala, M. C. 2006a. Variación de la comunidad de macroinvertebrados bentónicos en relación con la calidad de las aguas'. - Limnetica 25: 683692.
Oscoz, J., Leunda, P. M., Miranda, R. and Escala, M. C. 2006a. Summer feeding relationships of the co-occurring Phoxinus phoxinus and Gobio lozanoi (Cyprinidae) in an Iberian river. - Folia zool. 55: 418-432.

Paggi, A. C., Ocón, C., Tangorra, M. and Rodrigues Capítulo, A. 2006a. Response of the zoobenthos community along the dispersion plume of a highly polluted stream in the receiving waters of a large river (Rio de la Plata, Argentina). - Hydrobiologia 568: 114.

Paller, M. H., Specht, W. L. and Dyer, S. A. 2006a. Effects of stream size on taxa richness and other commonly used benthic bioassessment metrics. - Hydrobiologia 568: 309-316.

Panatta, Á., Stenert, C., Fagondes de Freitas, S. M. and Maltchik, L. 2006a. Diversity of chironomid larvae in palustrine wetlands of the coastal plain in the south of Brazil. Limnology 7: 23-30.

Park, H.-H. and Lee, J.-H. 2006a. Arthropod trophic relationships in a temperate rice ecosystem: a stable isotope analysis with $\delta^{13} \mathrm{C}$ and $\delta^{15}$ N. - Envir. Ent. 35: 684-693.

Paterson, M. J., Blanchfield, P. J., Podemski, C. Hintelmann, H. H., Gilmour, C. C., Harris, R., Ogrinc, N., Rudd, J. W. M. and Sandilands, K. A. 2006a. Bioaccumulation of newly deposited mercury by fish and invertebrates: an enclosure study using stable mercury isotopes. - Can. J. Fish. aquat. Sci. 63: 22132224.

Paus, A., Velle, G., Larsen, J., Nesje, A. and Lie, Ø. 2006a. Lateglacial nunataks in central Scandinavia: Biostratigraphical evidence for ice thickness from Lake Flåfattjønn, Tynset, Norway. - Quatern. Sci. Rev. 25: 1228-1246.

Penczak, T., Kruk, A., Grzybkowska, M. and Dukowska, M. 2006a. Patterning of impoundment impact on chironomid assemblages and their environment with use of the self-organizing map (SOM). - Acta oecol. 30: 312-321.

Pérez-Fuentetaja, A., Clapsadl, M. D., Einhouse, D., Bowser, P. R., Getchell, R. G. and Lee, W. T. 2006a. Influence of limnological conditions on Clostridium botulinum type E presence in eastern Lake Erie sediments (Great Lakes, USA). - Hydrobiologia 563: 189-200.

Persson, A. and Svensson, J. M. 2006a. Vertical distribution of benthic community responses 
to fish predators, and effects on algae and suspended material. - Aquat. Ecol. 40: 85-95.

Péry, A. R. R. and Garric, J. 2006a. Modelling effects of temperature and feeding level on the life cycle of the midge Chironomus riparius: an energy-based modelling approach. Hydrobiologia 553: 59-66.

Péry, A. R., Babut, M. P., Mons, R. and Garric, J. 2006a. Deriving effects on Chironomus population carrying capacity from standard toxicity tests. - Envir. Toxic. Chem. 25: 144148.

Péry, A. R., Geffard, A. and Garric, J. 2006a. Mechanistic models to perform population risk assessment with the midge Chironomus riparius: application to heavy metals. - Envir. Sci. Technol. 40: 6026-6031.

Peterson, M. S., Slack, W. T., Waggy, G. L., Finley, J., Woodley, C. M. and Partyka, M. L. 2006a. Foraging in non-native environments: comparison of Nile Tilapia and three cooccurring native centrarchids in invaded coastal Mississippi watersheds. - Envir. Biol. Fish. 76: 283-301.

Pike, T. W. 2006a. Fitness effects of parasitemediated spatial heterogeneity within a swarm. - Behav. Ecol. 17: 992-997.

Piscart, C., Moreteau, J.-C. and Beisel, J.-N. 2006a. Monitoring changes in freshwater macroinvertebrate communities along a salinity gradient using artificial substrates. Envir. Monit. Assess. 116: 529-542.

Płóciennik, M. 2006a. Zgrupowania Tanypodinae w rzekach Polski Środkowej o różnym stopniu zanieczyszczenia (Diptera: Chironomidae). (Tanypodinae communities in rivers with various pollution levels in Central Poland (Diptera: Chironomidae).) - Dipteron 22: 3637.

Polerecky, L., Volkenborn, N. and Stief, P. 2006a. High temporal resolution oxygen imaging in bioirrigated sediments. - Envir. Sci. Technol. 40: 5763-5769.

Pothoven, S. A. and Nalepa, T. F. 2006a. Feeding ecology of lake whitefish in Lake Huron. - $J$. Gt Lakes Res. 32: 489-501.

Potito, A. P., Porinchu, D. F., MacDonald, G. M. and Moser, K. A. 2006a. A late Quaternary chironomid-inferred temperature record from the Sierra Nevada, California, with connections to northeast Pacific sea surface temperatures. - Quatern. Res. 66: 356-363.
Pozhitkov, A., Noble, P. A., Domazet-Loso, T., Nolte, A. W., Sonnenberg, R., Staehler, P., Beier, M. and Tautz, D. 2006a. Tests of rRNA hybridization to microarrays suggest that hybridization characteristics of oligonucleotide probes for species discrimination cannot be predicted. - Nucl. Acids Res. 34: e66 (12 pp.)

Prenner, M. M., Ibrahim, H., Lewis, J. W. and Crane, M. 2006a.Toxicity and trace metal concentrations of sediments from Lake Maryut, Alexandria, Egypt.. - Bull. envir. Contam. Toxic. 77: 616-623.

Principe, R. E. and Corigliano, M. C. 2006a. Benthic, drifting and marginal macroinvertebrate assemblages in a lowland river: temporal and spatial variations and size structure. - Hydrobiologia 553: 303-317.

Proviz, V. I. 2006a. (Karyotype and morphology of Chironomus wulkeri (Diptera, Chironomidae) from Lake Baikal region.) -Zool. Zh. 85: 1495-1502. [also published in: Ent. Rev. 86: 1097-1104.]

Qi, X. and Wang, X. H. 2006a. Microtendipes Kieffer from China (Diptera: Chironomidae). - Zootaxa 1108: 37-51.

Radwell, A. J. and Brown, A. V. 2006a. Influence of fine sediments on meiofauna colonization densities in artificial stream channels. - Arch. Hydrobiol. 165: 63-75.

Rakotondravelo, M. L., Anderson, T. D., Charlton, R. E. and Zhu, K. Y. 2006a. Sublethal effects of three pesticides on larval survivorship, growth, and macromolecule production in the aquatic midge, Chironomus tentans (Diptera: Chironomidae). - Archs envir. Contam. Toxic. 51: 352-359.

Rakotondravelo, M. L., Anderson, T. D., Charlton, R. E. and Zhu, K. Y. 2006b. Sublethal effects of three pesticides on activities of selected target and detoxification enzymes in the aquatic midge, Chironomus tentans (Diptera: Chironomidae). - Archs envir. Contam. Toxic. 51: 360-366.

Ramírez, A. and Pringle, C. M. 2006a. Fast growth and turnover of chironomid assemblages in response to stream phosphorus levels in a tropical lowland reservoir. Limnol. Oceanogr. 51: 189-196.

Reavie, E. D., Neill, K. E., Little, J. L. and Smol, J. P. 2006a. Cultural eutrophication trends in three southeastern Ontario lakes: a 
paleolimnological perspective. - Lake Reservoir Mgmt 22: 44-58.

Ree, H. I. and Yum, J. H. 2006a. Redescription of Chironomus salinarius (Diptera: Chironomidae), nuisance midges that emerged in brackish water of Jinhae-man (Bay), Kyongsangnam-do, Korea. - Korean J. Parasitol. 44: 63-66.

Reichholf, J. H. 2006a. Die Auswirkung des Rückgangs der Teichrohrsänger Acrocephalus scirpaceus auf die Häufigkeit des Kuckucks Cuculus canorus. - Acta ornithoecol. 6: 3-19.

Reynolds, S. K. Jr. and Benke, A. C. 2006a. Chironomid emergence and relative emergent biomass from two Alabama streams. - SEast. Nat. 5: 165-174.

Rezsu, E. and Specziár, A. 2006a. Ontogenetic diet profiles and size-dependent diet partitioning of ruffe Gymnocephalus cernuus, perch Perca fluviatilis and pumpkinseed Lepomis gibbosus in Lake Balaton. - Ecol. Freshwat. Fish. 15: 339-349.

Riba, I., Delvalls, T. A., Reynoldson, T. B. and Milani, D. 2006a. Sediment quality in Rio Guadiamar (SW, Spain) after a tailing dam collapse: Contamination, toxicity and bioavailability. - Envir. Int. 32: 891-900.

Rickwood, C. J., Dubé, M. G., Weber, L. P., Driedger, K. L. and Janz, D. M. 2006a. Assessing effects of metal mining effluent on fathead minnow (Pimephales promelas) reproduction in a trophic-transfer exposure system. - Envir. Sci. Technol. 40: 6489-6497.

Rinehart, J. P., Hayward, S. A. L., Elnitsky, M. A., Sandro, L. H., Lee, R. E. Jr. and Denlinger, D. L. 2006a. Continuous upregulation of heat shock proteins in larvae, but not adults, of a polar insect. - Proc. natn. Acad. Sci. U. S. A. 103: 14223-14227.

Rios, S. L. and Bailey, R. C. 2006a. Relationship between riparian vegetation and stream benthic communities at three spatial scales. Hydrobiologia 553: 153-160.

Roessink, I., Belgers, J. D. M., Crum, S. J. H., van den Brink, P. J. and Brock, T. C. M. 2006a. Impact of triphenyltin acetate in microcosms simulating floodplain lakes. II. Comparison of species sensitivity distributions between laboratory and semi-field. Ecotoxicology 15: 411-424.

Roessink, I., Crum, S. J. H., Bransen, F., van Leeuwen, E., van Kerkum, F., Koelmans, A. A. and Brock, T. C. M. 2006a. Impact of triphenyltin acetate in microcosms simulating floodplain lakes. I. Influence of sediment quality. - Ecotoxicology 15: 267-293.

Roque, F. O. 206a. Chironomidae (Diptera) em córregos de baixa ordem em áreas florestadas do Estado de São Paulo. - Ph. D. Thes., Univ. Fed. São Carlos.

Rosecchi, E., Beck, N. and Mesléard, F. 2006a. Spatio-temporal changes in aquatic macroinvertebrate assemblages of conventional rice fields in the Camargue (Rhône-delta, France). - Vie Milieu 56: 55-63.

Rossaro, B., Boggero, A., Lencioni, V., Marziali, L. and Solimini, A. 2006a. Tools for the development of a benthic quality index for Italian lakes. - J. Limnol. 65: 41-51.

Rossaro, B., Lencioni, V., Boggero, A. and Marziali, L. 2006a. Chironomids from Southern Alpine running waters: ecology, biogeography. - Hydrobiologia 562: 231-246.

Rueda-Delgado, G., Wantzen, K. M. and Beltran Tolosa, M. 2006a. Leaf-litter decomposition in an Amazonian floodplain stream: effects of seasonal hydrological changes. - J. N. Am. benthol. Soc. 25: 233-249.

Ruiz, Z., Brown,. A. G. and Langdon, P. G. 2006a. The potential of chironomid (Insecta: Diptera) larvae in archaeological investingations of floodplain and lake settlements. - J. archaeol. Sci. 33: 14-33.

Sæther, O. A. 2006a. Japanese Pseudosmittia Edwards (Diptera: Chironomidae). - Zootaxa 1198: 21-51.

Safronov, G. P. 2006a. Gammaridae of Lake Hövsgöl. - In: Goulden, C. E., Sitnikova, T., Gelhaus, J. and Boldgiv, B. (eds.): The geology, biodiversity and ecology of Lake Hövsgöl (Mongolia), pp. 201-216. Backhuys Publs, Leiden.

Sambugar, B., Dessi, G., Sapelza, A., Stenico, A., Thaler, B. und Veneri, A. 2006a. Südtiroler Quellfauna / Fauna sorgentizia in Alto Adige. - Auton. Prov. Bozen, Ressort Raumordnung, Umwelt, Energie / Prov. Auton. Bolzano-Alto Adige, Dip. Urbanistica, Ambiente, Energia. $372 \mathrm{pp}$.

Samietz, R. 2006a. Die Chironomiden-Emergenz der Spitter 1975 bis 1977. - Abh. Ber. Mus. Nat. Gotha: 39-58.

Samietz, R. 2006b. Der Solgraben bei Artern als Lebensraum salzliebender Zuckmücken. Aratora 16: 132-135. 
Sánchez, M. I., Green, A. J,. and Alejandre, R. 2006a. Shorebird predation affects abundance and size distribution of benthic chironomids in saltpans: an exclosure experiment. - J. N. Am. benthol. Soc.25: 9-18.

Sánchez, M. I., Green, A. J. and Castellanos, E. M. 2006a. Temporal and spatial variation of an aquatic invertebrate community subjected to avian predation at the Odiel salt pans (SW Spain). - Arch. Hydrobiol. 166: 199-223.

Sánchez, M. I., Green, A. J. and Castellanos, E. M. 2006b. Spatial and temporal fluctuations in presence and use of chironomid prey by shorebirds in the Odiel saltpans, south-west Spain. - Hydrobiologia 567: 329-340.

Sanchez-Bayo, F. and Goka, K. 2006a. Ecological effects of the insecticide imidacloprid and a pollutant from antidandruff shampoo in experimental rice fields. - Envir. Toxic. Chem. 25: 1677-1687.

Sanseverino, A. M. and Fittkau, E. J. 2006a. Four new species of Tanytarsus van der Wulp, 1874 (Diptera: Chironomidae) from South America. - Zootaxa 1162: 1-18.

Sarkar, U. K., Lakra, W. S., Deepak, P. K., Negi, R. S., Paul, S. K. and Srivastava, A. 2006a. Performance of different types of diets on experimental larval rearing of endangered Chitala chitala (Hamilton) in recirculatory system. - Aquaculture 261: 141-150.

Sarmaja-Korjonen, K., Nyman, M., Kultti, S. and Väliranta, M. 2006a. Palaeolimnological development of Lake Njargajavri, Northern Finnish Lapland, in a changing Holocene climate and environment. - J. Paleolimnol. 35: 65-81.

Sarriquet, P. E., Delettre, Y. R. and Marmonier, P. 2006a. Effect of catchemnt disturbance on stream invertebrates: comparison of different habitats (vegetation, benthic and interstitial) using bio-ecological groups. - Annls Limnol. 42: 205-219.

Schlattner, U., Vafopoulou, X., Steel, C. G. H., Hormann, R. E. and Lezzi. M. 2006a. Nongenomic ecdysone effects and the invertebrate nuclear steroid hormone receptor EcR-new role for an "old" receptor? - Molec. cell. Endocr. 247: 64-72.

Schlattner, U., Vafopoulou, X., Steel, C. G. H., Hormann, R. E. and Lezzi. M. 2006b. Erratum to "Non-genomic ecdysone effects and the invertebrate nuclear steroid hormone receptor ECR-New role for an “old” receptor?” [Mol.
Cell Endocrinol. 247 (2006) 64-72]. - Molec. cell. Endocr. 253: 105.

Schleuter, D. and Eckmann, R. 2006a. Competition between perch (Perca fluviatilis) and ruffe (Gymnocephalus cernuus): the advantage of turning night into day. Freshwat. Biol. 51: 287-297.

Schuler, L. J, Landrum, P.F. and Lydy, M. J. 2006a. Comparative toxicity of fluoranthene and pentachlorobenzene to three freshwater invertebrates. - Envir. Toxic. Chem. 25: 985994.

Schulz, C., Günther, S., Wirth, M. and Rennert, B. 2006a. Growth performance and body composition of pike perch (Sander lucioperca) fed varying formulated and natural diets. - Aquacul. Int. 14: 577-586.

Servia, M. J., Heydorff, M., Péry, A. R. R., Garric, J. and Lagadic, L. 2006a. Sex- and developmental stage-related changes in energy reserves in fourth-instar larvae of the midge Chironomus riparius Meigen (Diptera: Chironomidae): implications for ecotoxicity testing. - Envir. Ent. 35: 865-874.

Servia, M. J., Péry, A. R. R., Heydorff, M., Garric, J. and Lagadic, L. 2006a. Effects of copper on energy metabolism and larval development in the midge Chironomus riparius. - Ecotoxicology 15: 229-240.

Shao, M. L., Xie, Z. C., Ye, L. and Cai, Q. H. 2006a. Changes in the benthic macroinvertebrates in Xiangxi Bay following dam closure to form the Three Gorges Reservoir. J. Freshwat. Ecol. 21: 717-719.

Shearer, J. 2006a. Macroinvertebrate bioassessment of Black Hills Streams, South Dakota. - Fin. Rep., SD GFP Report 2006-09, S. Dak. Game Fish Parks, Rapid City. 23 pp.

Singh, O. P., Visa, N., Wieslander, L. and Daneholt, B. 2006a. A specific SR protein binds preferentially to the secretory protein gene transcripts in salivary glands of Chironomus tentans. - Chromosoma 115: 449458.

Sipkay, Cs. és Hufnagel, L. 2006a. Szezonális dinamikai folyamatok egy balatoni makrogerinctelen együttesben. (Seasonal dynamic processes in an aquatic macroinvertebrate assembly on Lake Balaton.) - Acta biol. debrec., Suppl. oecol. hung. 14: 211-222.

Skoglund, H. and Barlaup, B. T. 2006a. Feeding pattern and diet of first feeding brown trout 
fry under natural conditions. - J. Fish Biol. 68: 507-521.

Soong, K., Chen, J. and Tsao, C.-J. 2006a. Adaptation for accuracy or for precision? Diel emergence timing of the intertidal insect Pontomyia oceana (Chironomidae). - Mar. Biol. 150: 173-181.

Soriano, O. y Cobo, F. 2006a. Lista faunística de los Quironómidos (Diptera, Chironomidae) de Madrid (España). - Graellsia 62, (Num. extraord.): 7-20.

Sotiropoulos, J. C., Nislow, K. H. and Ross, M. R. 2006a. Brook trout, Salvelinus fontinalis, microhabitat selection and diet under low summer stream flows. - Fish. Mgmt Ecol. 13: 149-155.

Souza Davanso, R. C. e Henry, R. 2006a. A biodiversidade bentônica em lagoa marginal ao rio Paranapanema na zona de sua desembocadura, na represa de Jurumirim. Acta Scient. biol. Sci. 28: 347-357.

Spänhoff, B., Reuter, C. and Meyer, E. I. 2006a. Epixylic biofilm and invertebrate colonization on submerged pine branches in a regulated lowland stream. - Arch. Hydrobiol. 165: 515536.

Spänhoff, B., Riss, W., Jäkel, P., Dakkak, N. and Meyer, E. I. 2006a. Effects of an experimental enrichment of instream habitat heterogeneity on the stream bed morphology and chironomid community of a straightened section in a sandy lowland stream. - Envir. Mgmt 37: 247-257.

Spies, M. 2006a. Case 3344. Pseudorthocladius Goetghebuer, 1943 and Mesosmittia Brundin, 1956 (Insecta, Diptera, CHIRONOMIDAE): proposed conservation of the generic names. Bull. zool. Nomencl. 63: 122-126.

Srivastava, D. S. 2006a. Habitat structure, trophic structure and ecosystem function: interactive effects in a bromeliad-insect community. Oecologia 149: 493-504.

Staiber, W. 2006a. Chromosome elimination in germ line - soma differentiation of Acricotopus lucidus (Diptera, Chironomidae). - Genome 49: 269-274.

Stevens, M. M., Helliwell, S. and Cranston, P. S. 2006a. Larval chironomid communities (Diptera: Chironomidae) associated with establishing rice crops in southern New South Wales, Australia. - Hydrobiologia 556: 317325.
Stief, P. and De Beer, D. 2006a. Probing the microenvironment of freshwater sediment macrofauna: Implications of deposit-feeding and bioirrigation for nitrogen cycling. Limnol. Oceanogr. 51: 2538-2548.

Stief, P. and Eller, G. 2006a. The gut microenvironment of sediment-dwelling Chironomus plumosus larvae as characterised with $\mathrm{O}_{2}$, $\mathrm{pH}$, and redox microsensors. - J. comp. Physiol. B, biochem. syst. envir. Physiol. 176: 673-683.

Stief, P.and Hölker, F. 2006a. Trait-mediated indirect effects of predatory fish on microbial mineralization in aquatic sediments. - Ecology 87: 3152-3159.

Strayer, D. L., Malcom, H. M., Bell, R. E., Carbotte, S. M. and Nitsche, F. O. 2006a. Using geophysical information to define benthic habitats in a large river. - Freshwat. Biol. 51: 25-38.

Strixino, G. e Trivinho-Strixino, S. 2006a. Herpobentos e haptobentos de lagoas marginais da Estação Ecológica de Jataí (Luiz Antônio, SP). - In: Dos Santos, J. E., Pires, J S. R. e Moschini, L. E. (eds.): Estudos integrados em ecossistema. Estação Ecológica de Jataí 4: 19-44. São Carlos.

Strongman, D. B. and Xu, S. 2006a. Trichomycetes from China and the description of three new Smittium species. - Mycologia. 98:479487.

Stur, E. and Ekrem, T. 2006a. A revision of West Palaearctic species of the Micropsectra atrofasciata species group (Diptera: Chironomidae). - Zool. J. Linn. Soc. 146: 165225.

Stur, E., Fittkau, E. J. and Serrano, M. A. S. 2006a. Parapentaneura bentogomensis gen. n., sp. n., a new Tanypodinae (Diptera, Chironomidae) from Brazil. - Zootaxa 1384: 59-68.

Sudduth, E. B. and Meyer, J. L. 2006a. Effects of bioengineered streambank stabilization on bank habitat and macroinvertebrates in urban streams. - Envir. Mgmt 38: 218-226.

Suren, A. M. and Lambert, P. 2006a. Do toxic baits containing sodium fluroacetate [sic!] (1080) affect fish and invertebrate communities when they fall into streams? - $N$. Z. Jl mar. Freshwat. Res. 40: 531-546.

Sushchik, N. N., Gladyshev, M. I., Kalachova, G. S., Makhutova, O. N. and Ageev, A. V. 2006a. Comparison of seasonal dynamics of 
the essential PUFA contents in benthic invertebrates and grayling Thymallus arcticus in the Yenisei river. - Comp. Biochem. Physiol. Pt B: Biochem. molec. Biol. 145. 278-287.

Sweetman, J. N. and Smol, J. P. 2006a. Reconstructing fish populations using Chaoborus (Diptera: Chaoboridae) remains - a review. Quatern. Sci. Rev. 25: 2013-2023.

Syväranta, J., Hämäläinen, H. and Jones, R. I. 2006a. Within-lake variability in carbon and nitrogen stable isotope signatures. - Freshwat. Biol. 51: 1090-1102.

Szító, A. and Györffy, Gy. 2006a. Data to the macrozoobenthos of backwater "Gyálai HoltTisza". - Tiscia 15: 85-87.

Szymczak-Żyła, M., Wawrzyniak-Wydrowska, B. and Kowalewska, G. 2006a. Products of chlorophyll $a$ transformation by selected benthic organisms in the Odra Estuary (southern Baltic Sea). - Hydrobiologia 554: 155-164.

Tall, L., Cattaneo, A., Cloutier, L., Dray, S. and Legendre, P. 2006a. Resource partitioning in a grazer guild feeding on a multilayer diatom mat. - J. N. Am. benthol. Soc. 25: 800-810.

Tall, L., Cloutier, L. and Cattaneo, A. 2006a. Grazer-diatom size relationships in an epiphytic community. - Limnol. Oceanogr. 51: 1211-1216.

Tanaka, M. O., Ribas, A. C. A. and de Souza, A. L. T. 2006a. Macroinvertebrate succession during leaf litter breakdown in a perennial karstic river in Western Brazil. Hydrobiologia 568: 493-498.

Tang, H.-Q. and Wang, X. 2006a. A new Antillocladius Saether from China (Diptera: Chironomidae). - Acta Scient. nat. Univ. Nankaiensis 2006, 2: 67-70.

Tarkowska-Kukuryk, M. 2006a. Water soldier Stratiotes aloides L. (Hydrocharitaceae) as a substratum for macroinvertebrates in a shallow eutrophic lake. - Pol. J. Ecol. 54: 441451.

Tátosová, J. and Stuchlík, E. 2006a. Seasonal dynamics of chironomids in the profundal zone of a mountain lake (Ladové pleso, the Tatra Mountains, Slovakia). - Biologia, Bratisl. 61, Suppl. 18: S203-S212.

Timm, H., Möls, T. and Timm, T. 2006a. Effects of long-term non-point eutrophication on the abundance and biomass of macrozoobenthos in small lakes of Estonia. - Proc. Eston. Acad. Sci. Biol. Ecol. 55: 187-198.

Tomanova, S., Goitia, E. and Helešic, J. 2006a. Trophic levels and functional feeding groups of macroinvertebrates in neotropical streams. Hydrobiologia 556: 251-264.

Tóth, M., Móra, A.és Dévai, Gy. 2006a. Árvaszúnyog-faunisztikai (Diptera: Chironomidae) vizsgálatok felső-Tisza-vidéki holtmedrekben. (Faunistical investigation on nonbiting midges (Diptera: Chironomidae) from backwaters at the Upper-Tisza region.) - Acta biol. debrec., Suppl. oecol. hung. 14: 245-251.

Tóth, M., Móra, A., Kiss, B. és Dévai, Gy. 2006a. Árvaszúnyoglárvák (Diptera: Chironomidae) előfordulási viszonyai a Boroszló-kerti-HoltTisza különböző növényállományaiban. (Occurrence of chironomid larvae (Diptera: Chironomidae) in different macrovegetation stands of the backwater Boroszló-kerti-HoltTisza.) - Hidrol. Közl. 86: 126-129.

Traunspurger, W., Bergtold, M., Ettemeyer, A. and Goedkoop, W. 2006a. Effects of copepods and chironomids on the abundance and vertical distribution of nematodes in a freshwater sediment. J. Freshwat. Ecol. 21: 81-90.

Tripole, S., Gonzalez, P., Vallania, A., Garbagnati, M. and Mallea, M. 2006a. Evaluation of the impact of acid mine drainage on the chemistry and the macrobenthos in the Carolina Stream (San Luis - Argentina). - Envir. Monit. Assess. 114: 377-389.

Trivinho Strixino, S. and Sonoda, K. C. 2006a. A new Tanytarsus (Insecta, Diptera, Chironomidae) from São Paulo, Brazil. Biota neotrop. 6, 2, BN03506022006: 1-9.

Usio, N., Suzuki, K., Konishi, M. and Nakano, S. 2006a. Alien vs. endemic crayfish: roles of species identity in ecosystem functioning. Arch. Hydrobiol. 166: 1-21.

Valladolid, M., Martínez-Bastida, J. J., Araúzo, M. y Gutiérrez, C. 2006a. Abundancia y biodiversidad de los macroinvertebrados del río Oja (La Rioja, España). - Limnetica 25: 745-752.

Vandendriessche, S., De Keersmaecker, G., Vincx, M. and Degraer, S. 2006a. Food and habitat choice in floating seaweed clumps: the obligate opportunistic nature of the associated macrofauna. - Mar. Biol. 149: 1499-1507. 
Van Wijngaarden, R. P. A., Brock, T. C. M., van den Brink, P. J., Gylstra, R. and Maund, S. J. 2006a. Ecological effects of spring and late summer applications of lambda-cyhalothrin on freshwater microcosms. - Archs envir. Contam. Toxic. 50: 220-239.

Vašek, M., Kubečka, J., Matěna, J. and Sed'a, J. 2006a. Distribution and diet of 0+ fish within a canyon-shaped European reservoir in late summer. - Int. Rev. Hydrobiol. 91: 178-194.

Vaughn, C. C. and Spooner, D. E. 2006a. Unionid mussels influence macroinvertebrate assemblage structure in streams. - J. N. Am. benthol. Soc. 25: 691-700.

Veerabahu, C., Radhika, D. and Kumar, D. 2006a. Life cycle and larval rearing of Chironomus ramosus using different organic nutrients. - Envir. Ecol., Kalyani 24: 373-378.

Velasco, J., Millán, A., Hernández, J., Gutiérrez, C., Abellán, P., Sánchez, D. and Ruiz, M. 2006a. Response of biotic communities to salinity changes in a Mediterranen hypersaline stream. - Saline Syst. 2, 12: 15 pp.

Verdonschot, P. F. M. 2006a. Data composition and taxonomic resolution in macroinvertebrate stream typology. Hydrobiologia 566: 59-74.

Verschuren, D. and Eggermont, H. 2006a. Quaternary paleoecology of aquatic Diptera in tropical and Southern Hemisphere regions, with special reference to the Chironomidae. Quatern. Sci. Rev. 25: 1926-1947.

Vogt, C., Nowak, C., Oetken, M. und Oehlmann, J. 2006a. Umweltschadstoffe und genetische Variabilität bei aquatischen Wirbellosen Ergebnisse einer Multigenerationsstudie mit C. riparius. - Dt. Ges. Limnol. TagBer. 2005: 487-491. DGL, Werder.

Walker, I. R. and Cwynar, L. C. 2006a. Midges and palaeotemperature reconstruction - the North American experience. - Quatern. Sci. Rev. 25: 1911-1925.

Walther, D. A., Whiles, M. R., Flinn, M. B. and Butler, D. W. 2006a. Assemblage-level estimation of nontanypodine chironomid growth and production in a southern Illinois stream. - J. N. Am. benthol. Soc. 25: 444-452.

Wang, L., Weigel, B. W., Kanehl, P. and Lohman, K. 2006a. Influence of riffle and snag habitat specific sampling on stream macroinvertebrate assemblage measures in bioassessment. - Envir. Monit. Assess. 119: 245-273.
Wang, X. H., Andersen, T and Saether, O. A. 2006a. Neotropical Bryophaenocladius Thienemann, 1934 (Diptera: Chironomidae). Stud. neotrop. Fauna Envir. 41: 19-32.

Wang, Y., Qu, X., Zhang, Y. and Jiao, X. 2006a. (Bioaccumulation of phosphorus by benthic macroinvertebrate in reservoirs at the Yellow River Delta.) - Ниро Кехие [= J. Lakes Sci.] 18: 173-178.

Wang, Y.-D. and Xiong, B.-X. 2006a. (Random amplified polymorphic DNA analysis of three chironomid species.) - Kunchong Zhishi [= Ent. Knowl.] 43: 355-360.

Wantzen, K. M. and Junk, W. J. 2006a. Aquaticterrestrial linkages from streams to rivers: biotic hot spots and hot moments. - Arch. Hydrobiol. Suppl. 158, Large Rivers 16: 595611.

Wantzen, K. M. and Wagner, R. 2006a. Detritus processing by invertebrate shredders: a neotropical-temperate comparison. - J. N. Am. benthol. Soc. 25: 214-230.

Warburton, K. and Thomson, C. 2006a. Costs of learning: the dynamics of mixed-prey exploitation by silver perch, Bidyanus bidyanus (Mitchell, 1838). - Anim. Behav. 71: 361-370.

Warren, D. R. and Kraft, C. E. 2006a. Invertebrate community and stream substrate responses to woody debris removal from an ice storm-impacted stream system, NY USA. Hydrobiologia 568: 477-488.

Watanabe, M., Sakashita, T., Fujita, A., Kikawada, T., Horikawa, D. D., Nakahara, Y., Wada, S., Funayama, T., Hamada, N,. Kobayashi, Y. and Okuda, T. 2006a. Biological effects of anhydrobiosis in an African chironomid, Polypedilum vanderplanki on radiation tolerance. - Int. J. Radiat. Biol. 82: 587-592.

White, M. M., Siri, A. and Lichtwardt, R. W. 2006a. Trichomycete insect symbionts in Great Smoky Mountains National Park and vicinity. - Mycologia 98: 333-352.

Wiedenbrug, S. 2006a. Chironomidae (Insecta, Diptera) aus Quellen und Quellbächen im Kalkquellenmoor "Benninger Ried", Bayern. Lauterbornia 57: 137-148.

Williams, L. R., Williams, M. G., Crubh, A. R. and Swinehart, E. E. 2006a. Food habits of the federally threatened leopard darter (Percina pantherina). - Am. Midl. Nat. 156: 208-211. 
Wills, T. C., Baker, E. A., Nuhfer, A. J. and Zorn, T. G. 2006a. Response of the benthic macroinvertebrate community in a northern Michigan stream to reduced summer streamflows. - River Res. Applics 22: 819-836.

Woelfl, S., Mages, M., Óvári, M. and Geller, W. 2006a. Determination of heavy metals in macrozoobenthos from the rivers Tisza and Szamos by total reflection X-ray fluorescence spectrometry. - Spectrochim. Acta, Pt B: Atom. Spectrosc. 61: 1153-1157.

Wong, K. F. and Ho, J. W. 2006a. Identification of histidine-60 interaction with copper in activation of Chironomidae ferrochelatase. Protein Pept. Lett. 13:443-446.

Woodward, C. A. and Shulmeister, J. 2006a. New Zealand chironomids as proxies for humaninduced and natural environmental change: Transfer functions for temperature and lake production (chlorophyll a). - J. Paleolimnol. 36: 407-429.

Wooster, D. E. and DeBano, S. J. 2006a. Effect of woody riparian patches in croplands on stream macroinvertebrates. - Arch. Hydrobiol. 165: 241-268.

Wu, Y., Zhou, S., Nie, J. and Yang, J. 2006a. (Study on inactivation of chironomid larvae by menadione compounds.) - Tongji Daxue Xuebao [= J. Tongji Univ.] 34: 1668-1673.

Yan, C. C. and Wang, X. H. 2006a. Microchironomus Kieffer from China (Diptera: Chironomidae). - Zootaxa 1108: 53-68.

Yan, C. C. and Wang, X. H. 2006b. Robackia Sæther from China (Diptera: Chironomidae). Zootaxa 1361: 53-59.

Yan, Y. and Li, X. 2006a. Secondary production and its trophic basis of five dominant chironomids in Heizhuchong Stream, Hanjiang River Basin. - Hupo Kexue [= J. Lakes Sci.] 18: 163-171.

Yan, Y. and Li, X. 2006b. Production dynamics and trophic basis of dominant chironomids (Diptera: Chironomidae) in a subtropical stream in China. - J. Freshwat. Ecol. 21: 439448.

Yan, Y. and Li, X. 2006c. Biomass turnover rates of snag chironomid larvae in a second order stream of middle China. - J. Freshwat. Ecol. 21: 657-662.

Yoshimura, C., Tockner, K., Omura, T. and Moog, O. 2006a. Species diversity and functional assessment of macroinvertebrate communities in Austrian rivers. - Limnology 7: 63-74.

Zabbey, $\mathrm{N}$ and Hart, A. I. 2006a. Influence of some physico-chemical parameters on the composition and distribution of benthic fauna in Woji Creek, Niger Delta, Nigeria. - Glob. J. pure appl. Sci. 12: 1-5.

Zelentzov, N. I. 2006a. (A new genus and a new species of Orthocladiinae (Diptera, Chironomidae) from the Novaya Zemlya Archipelago.) - Zool. Zh. 85: 775-779. [also published as: Ent. Rev. 86: 494-498.]

Zhang, E. L., Bedford, A., Jones, R., Shen, J., Wang, S. M. and Tang, H. Q. 2006a. A subfossil chironomid-total phosphorus inference model for lakes in the middle and lower reaches of the Yangtze River. - Chin. Sci. Bull. 51: 2125-2132.

Zhang, R. L., Wang, X. H. and Sæther, O. A. 2006a. Two unusual species of Polypedilum Kieffer (Diptera: Chironomidae) from Oriental China. - Zootaxa 1282: 39-48.

Zorina, O. V. 2006a. Dicrotendipes orientalis sp. n., a new species of non-biting midges (Diptera: Chironomidae: Chironominae) from the Russian Far East. - Russ. ent. J. 15: 79-82.

Zorina, O. V. 2006b. Cryptotendipes lyalichi sp. n. - novyi vid komarov-zvontsov (Diptera, Chironomidae, Chironominae) s yuga Dal'nego Vostoka Rossii. (Cryptotendipes lyalichi sp. n., a new species of non-biting midges (Diptera, Chironomidae, Chironominae) from the south of the Russian Far East.) - Evraziat. ent. Zh. (=Euroas. ent. J.) 5: 341-343.

Zorina, O. V. 2006c. Non-biting midges of the genus Paracladopelma Harnisch (Diptera: Chironomidae) from the Russian Far East. Zootaxa 1134: 29-49.

Zorina, O. V. 2006d. New species and records of Beckidia Sæther (Diptera: Chironomidae) from the Russian Far East. - Zootaxa 1151: 47-53.

\section{Curent Bibliography 2007}

Adámek, Z., Andreji, J. and Gallardo, J. M. 2007a. Food habits of four bottom-dwelling gobiid species at the confluence of the Danube and Hron Rivers (South Slovakia). - Int. Rev. Hydrobiol. 92: 554-563.

Aguilera, M. A. and Navarrete, S. A. 2007a. Effects of Chiton granosus (Frembly, 1827) and other molluscan grazers on algal 
succession in wave exposed mid-intertidal rocky shores of central Chile. - J. exp. mar. Biol. Ecol. 349: 84-98.

Alford, J. B. and Beckett, D. C. 2007a. Selective predation by four darter (Percidae) species on larval chironomids (Diptera) from a Mississippi stream. - Envir. Biol. Fishes 78: 353-364.

Ali, M. M., Mageed, A. A. and Heikal, M. 2007a. Importance of aquatic macrophyte for invertebrate diversity in large subtropical reservoir. - Limnologica 37: 155-169.

Álvarez, M. and Pardo, I. 2007a. Do temporary streams of Mediterranean islands have a distinct macroinvertebrate community? The case of Majorca. - Fundam. appl. Limnol. [= Arch. Hydrobiol.] 168: 55-70.

Andersen, T. 2009a. Contributions to the systematics and ecology of aquatic Diptera - $a$ tribute to Ole A. Scether. - Caddis Pr., Columbus. 358 pp.

Andersen, T. and Mendes, H. F. 2007a. Five enigmatic new orthoclad genera from Brazil (Diptera: Chironomidae, Orthocladiinae). - In: Andersen, T. (ed.): Contributions to the systematics and ecology of aquatic Diptera - a tribute to Ole A. Sather, pp. 17-52. Caddis Pr., Columbus.

Antunes, S. C., de Figueiredo, D. R., Marques, S. M., Castro, B. B., Pereira, R. and Gonçalves, F. 2007a. Evaluation of water column and sediment toxicity from an abandoned uranium mine using a battery of bioassays. - Sci. tot. Envir. 374: 252-259.

Applegate, J. M., Baumann, P. C., Emery, E. B. and Wooten, M. S. 2007a. First steps in developing a multimetric macroinvertebrate index for the Ohio River. - River Res. Applics 23: 683-697.

Arimoro, F. O., Ikomi, R. B. and Iwegbue, C. M. A. 2007a. Water quality changes in relation to Diptera community patte683-697.rns and diversity measured at an organic effluent impacted stream in the Niger Delta, Nigeria. Ecol. Indicators 7: 541-552.

Arocena, R. 2007a. Effects of submerged aquatic vegetation on macrozoobenthos in a coastal lagoon of the southwestern Atlantic. - Int. Rev. Hydrobiol. 92: 33-47.

Ashe, P. and O'Connor, J. P. 2007a. A new genus and species of Orthocladiinae (Diptera: Chironomidae) from Sulawesi, Indonesia. - In: Andersen, T. (ed.): Contributions to the systematics and ecology of aquatic Diptera - a tribute to Ole A. Scether, pp. 53-59. Caddis Pr., Columbus.

Bacey, J. and Spurlock, F. 2007a. Biological assessment of urban and agricultural streams in the California Central Valley. - Envir. Monit. Assess. 130: 483-493.

Battle, J. M., Jackson, J. K. and Sweeney, B. W. 2007a. Annual and spatial variation for macroinvertebrates in the Upper Mississippi River near Cape Girardeau, Missouri. Fundam. appl. Limnol. (= Arch. Hydrobiol.) 168: 39-54.

Battle, J. M., Jackson, J. K. and Sweeney, B. W. 2007b. Mesh size affects macroinvertebrate descriptions in large rivers: examples from the Savannah and Mississippi Rivers. Hydrobiologia 592: 329-343.

Becerra-Muñoz, S. and Schramm, H. L. Jr. 2007a. On the influence of substrate morphology and surface area on phytofauna. - Hydrobiologia 575: 117-128.

Benoit, J. B., Lopez-Martinez, G., Elnitsky, M. A., Lee, R. E. Jr. and Denlinger, D. L. 2007a. Moist habitats are essential for adults of the Antarctic midge, Belgica antarctica (Diptera: Chironomidae), to avoid dehydration. - Eur. J. Ent. 104: 9-14.

Benoit, J. B., Lopez-Martinez, G., Michaud, M. R., Elnitsky, M. A., Lee, R. E. Jr. and Denlinger, D. L. 2007a. Mechanisms to reduce dehydration stress in larvae of the Antarctic midge, Belgica antarctica. - J. Insect Physiol. 53: 656-667.

Benstead, J. P., Green, A. C., Deegan, L. A., Peterson, B. J., Slavik, K., Bowden, W. B. and Hershey, A. E. 2007a. Recovery of three arctic stream reaches from experimental nutrient enrichment. - Freshwat. Biol. 52: 1077-1089.

Berezina, N. 2007a. Food spectra and consumption rates of four amphipod species from the North-West of Russia. - Fundam. appl. Limnol. (= Arch. Hydrobiol.) 168: 317326.

Bertrand, K. N. and Gido, K. B. 2007a. Effects of the herbivorous minnow, southern redbelly dace (Phoxinus erythrogaster), on stream productivity and ecosystem structure. Oecologia 151: 69-81.

Bij De Vaate, A., Klink, A. G., Greijdanus-Klaas, M., Jans, L. H., Oosterbaan, J. and Kok, F. 2007a. Effects of habitat restoration on the 
macroinvertebrate fauna in a foreland along the river waal, the main distributary in the Rhine delta. - River Res. Applics 23: 171-183.

Bo, T., Fenoglio, S. and Malacarne, G. 2007a. Diet of Dinocras cephalotes and Perla marginata (Plecoptera: Perlidae) in an Apennine stream (northwestern Italy). - Can. Ent. 139: 358-364.

Bo, T., Fenoglio, S., Malacarne, G., Pessino, M. and Sgariboldi. F. 2007a. Effects of clogging on stream macroinvertebrates: An experimental approach. - Limnologica 37: 186-192.

Boix, D., Sala, J., Gascón, S., Martinoy, M., Gifre, J., Brucet, S., Badosa, A., LópezFlores, R. and Quintana, X. D. 2007a. Comparative biodiversity of crustaceans and aquatic insects from various water body types in coastal Mediterranean wetlands. Hydrobiologia 584: 347-359.

Bouldin, J. L., Farris’ J. L., Moore, M. T., Smith, S. Jr. and Cooper, C. M. 2007a. Assessment of diazinon toxicity in sediment and water of constructed wetlands using deployed Corbicula fluminea and laboratory testing. Archs envir. Contam. Toxic. 53: 174-182.

Braccia, A. and Voshell, J. R. Jr. 2007a. Benthic macroinvertebrate responses to increasing levels of cattle grazing in Blue Ridge Mountain streams, Virginia, USA. - Envir. Monit. Assess. 131: 185-200.

Brauns, M., Garcia, X.-F., Pusch, M. T. and Walz, N. 2007a. Eulittoral macroinvertebrate communities of lowland lakes: discrimination among trophic states. - Freshwat. Biol. 52: 1022-1032.

Bridge, P. D. and Denton, G. J. 2007a. Isolation of diverse viable fungi from the larvae of the introduced chironomid Eretmoptera murphyi on Signy Island. - Polar Biol. 30: 935-937.

Brodersen, K. P. 2007a. Chironomids (Diptera) from sub-saline lakes in West Greenland: diversity, assemblage structure and respiratory adaptation. - In: Andersen, T. (ed.): Contributions to the systematics and ecology of aquatic Diptera - a tribute to Ole A. Scether, pp. 61-58. Caddis Pr., Columbus.

Brooks, S. J. 2007a. Chironomid records: Late Pleistocene of Europe. - In: Elias, S. A. (ed.): Encyclopedia of Quaternary sciences 1: 377390. Elsevier, Oxf.

Burgmer, T., Hillebrand, H. and Pfenninger, M. 2007a. Effects of climate-driven temperature changes on the diversity of freshwater macroinvertebrates. - Oecologia 151: 93-103.

Buria, L., Albariño, R., Díaz Villanueva, V., Modenutti, B. and Balseiro, E. 2007a. Impact of exotic rainbow trout on the benthic macroinvertebrate community from AndeanPatagonian headwater streams. - Fundam. appl. Limnol. [= Arch. Hydrobiol.] 168: 145154.

Burmester, T. and Hankeln, T. 2007a. The respiratory proteins of insects. - J. Insect Physiol. 53: 285-294.

Burmester, T., Klawitter. S. and Hankeln, T. 2007a. Characterization of two globin genes from the malaria mosquito Anopheles gambiae: Divergent origin of nematoceran haemoglobins. - Insect molec. Biol. 16: 133142.

Buzby, K. M. and Viadero, R. C. Jr. 2007a. Structural and functional aspects of treated mine water and aquaculture effluent streams. Hydrobiologia 583: 251-263.

Byström, P., Karlsson, J., Nilsson, P., van Kooten, T., Ask, J. and Olofsson, F. 2007a. Substitution of top predators: effects of pike invasion in a subarctic lake. - Freshwat. Biol. 52: 1271-1280.

Caldwell, B. A. 2007a. Morphological variation, additional distribution records, and notes on ecology of Pagastia orthogonia Oliver (Diptera: Chironomidae). - In: Andersen, T. (ed.): Contributions to the systematics and ecology of aquatic Diptera - a tribute to Ole A. Scether, pp. 69-72. Caddis Pr., Columbus.

Caquet, T., Hanson, M. L., Roucaute, M., Graham, D. W. and Lagadic, L. 2007a. Influence of isolation on the recovery of pond mesocosms from the application of an insecticide. II. Benthic macroinvertebrate responses. - Envir. Toxic. Chem. 26: 12801290.

Carlisle, D. M., Meador, M. R., Moulton, S. R. II and Ruhl, P. M. 2007a. Estimation and application of indicator values for common macroinvertebrate genera and families of the United States. - Ecol. Indicators 7: 22-33.

Carvalho, S., Curdia, J., Moura, A. Gaspar, M. B., Dinis, M. T., Pousão-Ferreira, P. and da Fonseca, L. C. 2007a. The influence of white seabrearn (Diplodus sargus) production on macrobenthic colonization patterns. - Acta oecol. 31: 307-315. 
Chara [correctly: Chará], J., Baird, D., Telfer, T. and Giraldo, L. 2007a. A comparative study of leaf breakdown of three native tree species in a slowly-flowing headwater stream in the Colombian Andes. - Int. Rev. Hydrobiol. 92: 183-198.

Cheng, X., Li, S., Shen, Q. and Xue, J. 2007a. Response of cultural lake eutrophication to hemp-retting in Quidenham Mere of England in post-medieval. - Chin. geogr. Sci. 17: 6974.

Chessman, B., Williams, S. and Besley, C. 2007a. Bioassessment of streams with macroinvertebrates: effect of sampled habitat and taxonomic resolution. - J. N. Am. benthol. Soc. 26: 546-565.

Connolly, N. M. and Pearson, R. G. 2007a. The effect of fine sedimentation on tropical stream macroinvertebrate assemblages: a comparison using flow-through artificial stream channels and recirculating mesocosms. - Hydrobiologia 592: 423-438.

Cottet, M., de Montaudouin, X., Blanchet, H. and Lebleu, P. 2007a. Spartina anglica eradication experiment and in situ monitoring assess structuring strength of habitat complexity on marine macrofauna at high tidal level. Estuar. coast. Shelf Sci. 71: 629-640.

Correia, L. C. S. and Trivinho-Strixino, S. 2007a. New species of Chironomus Meigen (Diptera: Chironomidae: Chironominae) from Brazil. Zootaxa 1504: 53-68.

Correia, L. C. S. and Trivinho-Strixino, S. 2007b. Erratum: [Correia, L. C. D. S. and TrivinhoStrixino, S. (2007). New species of Chironomus Meigen (Diptera: Chironomidae: Chironominae) from Brazil. Zootaxa, 1504, 53-68.] - Zoozaxa 1527: 67-68.

Couceiro, S. R. M., Hamada, N., Luz, S. L. B., Forsberg, B. R. and Pimentel, T. P. 2007a. Deforestation and sewage effects on aquatic macroinvertebrates in urban streams in Manaus, Amazonas, Brazil. - Hydrobiologia 575: 271-284.

Cranston, P. S. 2007a. The identity of Dactylocladius commensalis (Diptera: Chironomidae) revealed. - Aquat. Insects 29: 103-114.

Cranston, P. S. 2007b. A new species for a bromeliad phytotelm-dwelling Tanytarsus (Diptera: Chironomidae). - Ann. ent. Soc. Am. 100: 617-622.
Cranston, P. S. 2007c. The Chironomidae larvae associated with the tsunami-impacted waterbodies of the coastal plain of southwestern Thailand. - Raffles Bull. Zool. 55: 231-244.

Cranston, P. S., Benigno, G. M. and Dominguez, M. C. 2007a. Hydrobaenus saetheri Cranston, new species, an aestivating, winter-emerging chironomid (Diptera: Chironomidae) from California. - In: Andersen, T. (ed.): Contributions to the systematics and ecology of aquatic Diptera - a tribute to Ole A. Sather, pp. 73-79. Caddis Pr., Columbus.

Dallai, R., Lombardo, B. M. and Lupetti, P. 2007a. Sperm ultrastructure in Chironomoidea (Insecta, Diptera). - Tissue Cell 39: 179-194.

Dallas, H. F. and Day, J. A. 2007a. Natural variation in macroinvertebrate assemblages and the development of a biological banding system for interpreting bioassessment data -a preliminary evaluation using data from upland sites in the south-western Cape, South Africa. - Hydrobiologia 575: 231-244.

Danehy, R. J., Chan, S. S., Lester, G. T., Langshaw, R. B. and Turner, T. R. 2007a. Periphyton and macroinvertebrate assemblage structure in headwaters bordered by mature, thinned, and clearcut douglas-fir stands. - For. Sci. 53: 294-307.

Danks, H. V. 2007a. How aquatic insects live in cold climates. - Can. Ent. 139: 443-471.

Datry, T., Larned, S. T. and Scarsbrook, M. R. 2007a. Responses of hyporheic invertebrate assemblages to large-scale variation in flow permanence and surface-subsurface exchange. - Freshwat. Biol. 52: 1452-1462.

Deines, P., Bodelier, P. L. E. and Eller, G. 2007a. Methane-derived carbon flows through methane-oxidizing bacteria to higher trophic levels in aquatic systems. - Envir. Microbiol. 9: 1126-1134.

Deines, P., Grey, J, Richnow, H.-H. and Eller, G. 2007a. Linking larval chironomids to methane: seasonal variation of the microbial methane cycle and chironomid $\delta^{13} \mathrm{C}$. - Aquat. microb. Ecol. 46: 273-282.

Dhadialla, T. S., Le, D., Palli, S. R., Raikhel, A. and Carlson, G. R. 2007a. A photoaffinity, non-steroidal, ecdysone agonist, bisacylhydrazine compound, RH-131039: Characterization of binding and functional activity. - Insect Biochem. molec. Biol. 37: 865-875. 
Dimitriadis, S. and Cranston, P. S 2007a. From the mountains to the sea: assemblage structure and dynamics in Chironomidae (Insecta: Diptera) in the Clyde River estuarine gradient, New South Wales, south-eastern Australia. Aust. J. Ent. 46: 188-197.

Dineen, G., Harrison, S. S. C. and Giller, P. S. 2007a. Diet partitioning in sympatric Atlantic salmon and brown trout in streams with contrasting riparian vegetation. - J. Fish Biol. 71: 17-38.

Doi, H., Kikuchi, E., Takagi, S. and Shikano, S. 2007a. Changes in carbon and nitrogen stable isotopes of chironomid larvae during growth, starvation and metamorphosis. - Rapid Communs Mass Spectrom. 21:997-1002.

Doi, H., Takagi, A. and Kikuchi, E. 2007a. Stream macroinvertebrate community affected by point-source metal pollution. - Int. Rev. Hydrobiol. 92: 258-266.

Doitteau, G. and Nel, A. 2007a. Chironomid midges from early Eocene amber of France (Diptera: Chironomidae). - Zootaxa 1404: 166.

Domingues, I., Guilhermino, L., Soares, A. M. V. M. and Nogueira, A. J. A. 2007a. Assessing dimethoate contamination in temperate and tropical climates: Potential use of biomarkers in bioassays with two chironomid species. Chemosphere 69: 145-154.

Duggan, I. C.,. Boothroyd, I. K. G and Speirs, D. A. 2007a. Factors affecting the distribution of stream macroinvertebrates in geothermal areas: Taupo Volcanic Zone, New Zealand. Hydrobiologia 592: 235-247.

Dukowska, M., Szczerkowska, E., Grzybkowska, M., Tszydel, M. and Penczak, T. 2007a. Effect of flow manipulations on benthic fauna communities in a lowland river: interhabitat comparison. - Pol. J. Ecol. 55: 101-112.

Dumnicka, E., Galas, J. and Koperski, P. 2007a. Benthic invertebrates in karst springs: Does substratum or location define communities? Int. Rev. Hydrobiol. 92. 452-464.

Edwards, K. J., Langdon, P. G. and Sugden, H. 2007a. Separating climatic and possible human impacts in the early Holocene: biotic response around the time of the $8200 \mathrm{cal}$. yr BP event. - J. Quatern. Sci. 22: 77-84.

Eedy, R. I. and Giberson, D. J. 2007a. Macroinvertebrate distribution in a reach of a north temperate eastern Canadian river: Relative importance of detritus, substrate and flow. - Fundam. appl. Limnol. (= Arch. Hydrobiol.) 169: 101-114.

Eggermont, H. and Verschuren, D. 2007a. Taxonomy and diversity of Afroalpine Chironomidae (Insecta: Diptera) on Mount Kenya and the Rwenzori Mountains, East Africa. - J. Biogeogr. 34: 69-89.

Eggermont, H. and Verschuren, D. 2007b. Chironomid records: Africa. - In: Elias, S. A. (ed.): Encyclopedia of Quaternary sciences 1: 367-377. Elsevier, Oxf.

Eggermont, H., De Deyne, P. and Verschuren, D. 2007a. Spatial variability of chironomid death assemblages in the surface sediments of a fluctuating tropical lake (Lake Naivasha, Kenya). - J. Paleolimnol. 38: 309-328.

Ekrem, T. 2007a. A taxonomic revision of the genus Stempellinella (Diptera: Chironomidae). - J. nat. Hist. 41: 1367-1465.

Ekrem, T. and Andersen, T. 2007a. Professor Ole Anton Sæther 70 years: Four decades of chironomid research. - In: Andersen, T. (ed.): Contributions to the systematics and ecology of aquatic Diptera - a tribute to Ole A. Scether, pp. 1-15. Caddis Pr., Columbus.

Ekrem, T. and Halvorsen, G. A. 2007a. Taxonomy of Tanytarsus lapponicus Lindeberg, 1970, a species with larval mandible of 'lugens-type' (Diptera: Chironomidae). - In: Andersen, T. (ed.): Contributions to the systematics and ecology of aquatic Diptera - a tribute to Ole A. Sæether, pp. 81-86. Caddis Pr., Columbus.

Ekrem, T. and Stur, E. 2007a. Description of Tanytarsus hjulorum, new species, with notes and DNA barcodes of some South African Tanytarsus (Diptera: Chironomidae). - In: Andersen, T. (ed.): Contributions to the systematics and ecology of aquatic Diptera - a tribute to Ole A. Scther, pp. 87-92. Caddis Pr., Columbus.

Ekrem, T., Willassen, E. and Stur, E. 2007a. A comprehensive DNA sequence library is essential for identification with DNA barcodes. - Molec. Phylogenet. Evol. 43: 530542.

Eller, G., Deines, P. and Krüger, M. 2007a. Possible sources of methane-derived carbon for chironomid larvae. - Aquat. microb. Ecol. 46: 283-293.

Endo, K. 2007a. Taxonomic notes on the genus Syndiamesa Kieffer (Diptera: Chironomidae) 
from Japan, with description of a new species. - Ent. Sci. 10: 291-299.

Endo, K., Makarchenko, E. A. and Willassen, E. 2007a. On the systematics of Linevitshia Makarchenko, 1987 (Diptera: Chironomidae, Diamesinae), with the description of $L$. yezoensis Endo, new species. - In: Andersen, T. (ed.): Contributions to the systematics and ecology of aquatic Diptera - a tribute to Ole A. Scether, pp. 93-98. Caddis Pr., Columbus.

Entrekin, S. A., Rosi-Marshall, E. J., Tank, J. L., Hoellein, T. J. and Lamberti, G. A. 2007a. Macroinvertebrate secondary production in 3 forested streams of the upper Midwest, USA. J. N. Am. benthol. Soc. 26: 472-490.

Entrekin, S. A., Wallace, J. B. and Eggert, S. L. 2007a. The response of Chironomidae (Diptera) to a long-term exclusion of terrestrial organic matter. - Hydrobiologia 575: 401-413.

Faria, M. S., Lopes, R. J., Nogueira, A. J. A. and Soares, A. M. V. M. 2007a. In situ and laboratory bioassays with Chironomus riparius larvae to assess toxicity of metal contamination in rivers: the relative toxic effect of sediment versus water contamination. - Envir. Toxic. Chem. 26: 1968-1977.

Faria, M. S., Nogueira, A. J. A. and Soares, A. M. V. M. 2007a. The use of Chironomus riparius larvae to assess effects of pesticides from rice fields in adjacent freshwater ecosystems. Ecotoxic. envir. Saf. 67: 218-226.

Feld, C. K. and Hering, D. 2007a. Community structure or function: effects of environmental stress on benthic macroinvertebrates at different spatial scales. - Freshwat. Biol. 52: 1380-1399.

Fenoglio, S., Bo, T., Pessino, M. and Malacarne, G. 2007a. Feeding of Perla grandis nymphs (Plecoptera: Perlidae) in an apennine first order stream (Rio Berga, NW Italy). - Annls Soc. ent. Fr. 43: 221-224.

Ferrington, L. C. Jr. 2007a. Hibernal patterns of Chironomidae in lotic habitats of Kansas versus substrate composition. - In: Andersen, T. (ed.): Contributions to the systematics and ecology of aquatic Diptera - a tribute to Ole A. Scether, pp. 99-105. Caddis Pr., Columbus.

Forcella, M., Berra, E., Giacchini, R. and Parenti, P. 2007a. Antioxidant defenses preserve membrane transport activity in Chironomus riparius larvae exposed to anoxia. - Archs Insect Biochem. Physiol. 65: 181-194.

Forcella, M., Berra, E., Giacchini, R., Rossaro, B. and Parenti, P. 2007a. Increased alanine concentration is associated with exposure to fenitrothion but not carbamates in Chironomus riparius larvae. - Ecotoxic. envir. Saf. 66: 326-334.

Frei, M., Khan, M. A. M., Razzak, M. A., Hossain, M. M., Dewan, S. and Becker, K. 2007a. Effects of a mixed culture of common carp, Cyprinus carpio L., and Nile tilapia, Oreochromis niloticus (L.), on terrestrial arthropod population, benthic fauna, and weed biomass in rice fields in Bangladesh. - Biol. Control 41: 207-213.

Frouz, J., Lobinske, R. J., Yaqub, A. and Ali, A. 2007a. Larval gut $\mathrm{pH}$ profile in pestiferous Chironomus crassicaudatus and Glyptotendipes paripes (Chironomidae: Diptera) in reference to the toxicity potential of Bacillus thuringiensis serovar israelensis. J. Am. Mosquito Control Ass. 23: 355-358.

Füreder, L 2007a. Life at the edge: Habitat condition and bottom fauna of Alpine running waters. - Int. Rev. Hydrobiol. 92: 491-513.

Gafner, K. and Robinson, C. T. 2007a. Nutrient enrichment influences the responses of stream macroinvertebrates to disturbance. - J. N. Am. benthol. Soc. 26: 92-102.

Gandouin, E., Ponel, P., Andrieu-Ponel, V., Franquet, E., de Beaulieu, J.-L., Reille, M., Guiter, F., Brulhet, J., Lallier-Vergès, E., Keravis, D., von Grafenstein, U. and Veres, D. 2007a. Past environment and climate changes at the last Interglacial/Glacial transition (Les Échets, France) inferred from subfossil chironomids (Insecta). - C. $r$. Geosci. 339: 337-346.

Gandouin, E., Ponel, P., Franquet, E., Van VlietLanoë, B., Andrieu-Ponel, V., Keen, D. H., Brulhet, J. and Brocandel, M. 2007a. Chironomid responses (Insect: Diptera) to Younger Dryas and Holocene environmental changes in a river floodplain from northern France (St-Momelin, St-Omer basin). Holocene 17: 331-347.

García, P. E. and Añón Suárez, D. A. 2007a. Community structure and phenology of chironomids (Insecta: Chironomidae) in a Patagonian Andean stream. - Limnologica 37: 109-117. 
Gido, K. B. and Franssen, N. R. 2007a. Invasion of stream fishes into low trophic positions. Ecol. Freshwat. Fish 16: 457-464.

Giłka, W. and Dominiak, P. 2007a. Tanytarsini (Diptera: Chironomidae) of the Kashubian Lakeland. - Fragm. faun. 50: 47-55.

Giłka, W. and Paasivirta, L. 2007a. Two new species of the genus Tanytarsus van der Wulp (Diptera: Chrionomidae) from Fennoscandia. In: Andersen, T. (ed.): Contributions to the systematics and ecology of aquatic Diptera - a tribute to Ole A. Scether, pp. 107-113. Caddis Pr., Columbus.

Golubkov, S., Kemp, R., Golubkov, M., Balushkina, E., Litvinchuk, L.a nd Gubelit, Yu. 2007a. Biodiversity and the functioning of hypersaline lake ecosystems from Crimea Peninsula (Black Sea). - Fundam. appl. Limnol. [= Arch. Hydrobiol.] 169: 79-87.

Gonçalves, J. F. Jr., Graça, M. A. S. and Callisto, M. 2007a. Litter decomposition in a Cerrado savannah stream is retarded by leaf toughness, low dissolved nutrients and a low density of shredders. - Freshwat. Biol. 52: 1440-1451.

Goedkoop, W., Demandt, M. and Ahlgren, G. 2007a. Interactions between food quantity and quality (long-chain polyunsaturated fatty acid concentrations) effects on growth and development of Chironomus riparius. - Can. J. Fish. aquat. Sci. 64: 425-436.

Gresens, S. E., Belt, K. T., Tang, J. A., Gwinn, D. C. and Banks, P. A. 2007a. Temporal and spatial responses of Chironomidae (Diptera) and other benthic invertebrates to urban stormwater runoff. - Hydrobiologia 575: 173190.

Gruberts, D., Druvietis, I., Parele, E., Paidere, J., Poppels, A., Prieditis, J. and Skute, A. 2007a. Impact of hydrology on aquatic communities of floodplain lakes along the Daugava River (Latvia). - Hydrobiologia 584: 223-237.

Guarneri, F., Guarneri, C. and Benvenga, S. 2007a. Cross-reactivity of Anisakis simplex: possible role of Ani s 2 and Ani s 3. - Int. J. Dermatol. 46: 146-150.

Halpern, M., Landsberg, O., Raats, D. and Rosenberg, E. 2007a. Culturable and VBNC Vibrio cholerae: interactions with chironomid egg masses and their bacterial population. Microb. Ecol. 53: 285-293.

Halpern, M., Senderovich, Y. and Snir, S. 2007a. Rheinheimera chironomi sp. nov., isolated from a chironomid (Diptera; Chironomidae) egg mass. - Int. J. syst. evol. Microbiol. 57: 1872-1875.

Harrison, A. D. and Cranston, P. S. 2007a. Elpiscladius Harrison and Cranston, a new orthoclad (Diptera: Chironomidae) in the Brillia-group from South Africa. - Ann. east. Cape Mus. 6: 1-11.

Heiri, O. 2007a. Chironomid records: Postglacial Europe. - In: Elias, S. A. (ed.): Encyclopedia of Quaternary sciences 1: 390-398. Elsevier, Oxf.

Heiri, O. and Lotter, A. F. 2007a. Sciaridae in lake sediments: indicators of catchement and stream contribution to fossil insect assemblages. - J. Paleolimnol. 38: 183-189.

Henriques-de-Oliveira, C., Baptista, D. F. and Nessimian, J. L.2007a. Sewage input effects on the macroinvertebrate community associated to Typha domingensis Pers in a coastal lagoon in southeastern Brazil. - Braz. J. Biol. 67: 73-80.

Herwig, B. R., Wahl, D. H., Dettmers, J. M. and Soluk, D. A. 2007a. Spatial and temporal patterns in the food web structure of a large floodplain river assessed using stable isotopes. - Can. J. Fish. aquat. Sci. 64: 495-508.

Hicham, K. and Lotfi, A. 2007a. The dynamics of macroinvertebrate assemblages in response to environmental change in four basins of the Etueffont landfill leachate (Belfort, France). Wat. Air Soil Pollut. 185: 63-77.

Hirabayashi, K., Kimura, G., Fukunaga, Y. and Yamamoto, M. 2007a. Distribution pattern of chironomid midges (Diptera: Chironomidae) in the upper and middle reaches of the Shinano River in Central Japan. - In: Andersen, T. (ed.): Contributions to the systematics and ecology of aquatic Diptera - a tribute to Ole A. Scther, pp. 129-136. Caddis Pr., Columbus.

Hogsden, K. L., Sager, E. P. S. and Hutchinson, T. C. 2007a. The impacts of the non-native macrophyte Cabomba caroliniana on littoral biota of Kasshabog Lake, Ontario. - J. Gt Lakes Res. 33: 497-504.

Horrigan, N., Dunlop, J. E., Kefford, B. J. and Zavahir, F. 2007a. Acute toxicity largely reflects the salinity sensitivity of stream macroinvertebrates derived using field distributions. - Mar. Freshwat. Res. 58: 178186.

Hose, G. C., Walter, T. and Brooks, A. J. 2007a. Short-term colonisation by macroinvertebrates 
of cobbles in main channel and inundated stream bank habitats. - Hydrobiologia 592: 513-522.

Hribar, L. J. and J. H. Epler. 2007a. Collection records for some Chironomidae (Diptera) in the Florida Keys. - Fla Scient. 70: 110-112.

Hurley, B. P., Govender, P., Coutinho, T. A., Wingfield, B. D. and Wingfield, M. J. 2007a. Fungus gnats and other Diptera in South African forestry nurseries and their possible association with the pitch canker fungus. - $S$. Afr. J. Sc. 103: 43-46.

Ilyashuk, B. P. and Ilyashuk, E. A. 2007a. Chironomid record of Late Quaternary climatic and environmental changes from two sites in Central Asia (Tuva Republic, Russia) local, regional or global causes? - Quatern. Sci. Rev. 26: 705-731.

Istvánovics, V., Clement, A., Somlyódy, L., Specziár, A., G.-Tóth, L. and Padisák, J. 2007a. Updating water quality targets for shallow Lake Balaton (Hungary), recovering from eutrophication. - Hydrobiologia 581: 305-318.

Jacobsen, R. E. 2007a. Orthocladius (Orthocladius) saetheri, new species, from the Appalachian Mountains (Diptera: Chironomidae). - In: Andersen, T. (ed.): Contributions to the systematics and ecology of aquatic Diptera - a tribute to Ole A. Scether, pp. 137143. Caddis Pr., Columbus.

Jacobsen, R. E. and Bilyj, B. 2007a. An unusual new Cladotanytarsus from oligotrophic Florida Everglades marshes (Diptera: Chironomidae). - In: Andersen, T. (ed.): Contributions to the systematics and ecology of aquatic Diptera - a tribute to Ole A. Scether, pp. 145-154. Caddis Pr., Columbus.

Jacobsen, R. E. and Perry, S. A. 2007a. Polypedilum nubifer, a chironomid midge (Diptera: Chironomidae) new to Florida that has nuisance potential. - Fla Ent. 90: 264-267.

Jansen, S. 2007a. Foreword. - In: Andersen, T. (ed.): Contributions to the systematics and ecology of aquatic Diptera - a tribute to Ole A. Scether, pp. iii. Caddis Pr., Columbus.

Jenderedjian, K., Hakobyan, S., Jenderedjian, A. 2007a. Use of benthic invertebrates as indicators of pollution origin in agricultural and urban areas. - In: Ebel, A. and Divitashvili, T. (eds.): Air, water and soil quality modelling for risk and impact assessment. NATO Security through Science
Series C: Environmental Security, pp. 217220.

Ji, C. W., Lee, S. H., Choi, K.-H., Kwak, I.-S., Lee, S. G., Cha, E. Y., Lee, S.-K. and Chon, T.-S. 2007a. Monitoring of movement behaviors of chironomid larvae after exposure to diazinon using fractal dimension and selforganizing map. - Int. J. Ecodynamics 2: 2738.

Jocqué, M., Graham, T. and Brendonck, L. 2007a. Local structuring factors of invertebrate communities in ephemeral freshwater rock pools and the influence of more permanent water bodies in the region. Hydrobiologia 592: 271-280.

Johnson, A. A. and Kleve, M. G. 2007a. A new mermithid nematode from Ablabesmyia monilis (L.) (Diptera: Chironomidae) in northern Minnesota. - J. Parasit. 93: 155-158.

Johnson, R. L., Coghlan, S. M. and Harmon, T. 2007a. Spatial and temporal variation in prey selection of brown trout in a cold Arkansas tailwater. - Ecol. Freshwat. Fish 16: 373-384.

Kachvoryan, E. A., Oganesyan, V. S., Petrova, N. A. i Zelentsov, N. I. 2007a. (The fauna of chironomids and blackflies (Diptera: Chironomidae, Simuliidae) and hydrochemical characteristics of the Hrazdan River (Armenia).) - Ent. Obozr. 86: 73-82. [also published as: Ent. Rev. 87: 73-81.]

Kaller, M. D. and Kelso , W. E. 2007a. Association of macroinvertebrate assemblages with dissolved oxygen concentration and wood surface area in selected subtropical streams of the southeastern USA. - Aquat. Ecol. 41: 95-110.

Karrow, P. F., Morris, T. F., McAndrews, J. H., Morgan, A. V., Smith, A. J. and Walker, I. R. 2007a. A diverse late-glacial (Mackinaw Phase) biota from Leamington, Ontario. Can. J. Earth Sci. 44: 287-296.

Kateyo, E. M. 2007a. Ecology of a nutrientdeficient interface zone of Lake Nabugabo, Uganda. - Afr. J. Ecol. 45: 282-284.

Kefford, B. J., Nugegoda, D., Zalizniak, L., Fields, E. J. and Hassell, K. L. 2007a. The salinity tolerance of freshwater macroinvertebrate eggs and hatchlings in comparison to their older life-stages: a diversity of responses. - Aquat. Ecol. 41: 335-348.

Kelly, D. J. and Jelyman, D. J. 2007a. Changes in trophic linkages to shortfin eels (Anguilla australis) since the collapse of submerged 
macrophytes in Lake Ellesmere, New Zealand. - Hydrobiologia 579: 161-173.

Keyse, M. D., Fortino, K., Hershey, A. E., O’Brien, W. J., Lienesch, P. W., Luecke, C. and McDonald, M. E. 2007a. Effects of large lake trout (Salvelinus namaycush) on the dietary habits of small lake trout: a comparison of stable isotopes $\left(\delta^{15} \mathrm{~N}\right.$ and $\left.\delta^{13} \mathrm{C}\right)$ and stomach content analyses. Hydrobiologia 579: 175-185.

Khudamrongsawat, J. and Kuhajda, B. R. 2007a. Life history of the Warrior darter (Etheostoma bellator) and comparison with the endangered vermilion darter (Etheostoma chermocki). - J. Freshwat. Ecol. 22: 241-248.

King, R. S. and Richardson, C. J. 2007a. Subsidystress response of macroinvertebrate community biomass to a phosphorus gradient in an oligotrophic wetland ecosystem. - J. N. Am. benthol. Soc. 26: 491-508.

Kipriyanova, L. M., Yermolaeva, N. I., Bezmaternykh, D. M., Dvurechenskaya, S. Ya. and Mitrofanova, E. Yu. 2007a. Changes in the biota of Chany Lake along a salinity gradient. - Hydrobiologia 576: 83-93.

Kobayashi, T. 2007a. Kloosia Kruseman, Chernovskiia Sæther, Robackia Sæther, and Saetheria Jackson (Chironomidae: Chironominae) in Japan. - Zootaxa 1527: 1-15.

Kobayashi, T., Nakazato, R. and Higo, M. 2007a. The identity of Japanese Lipiniella Shilova species (Diptera: Chironomidae). - In: Andersen, T. (ed.): Contributions to the systematics and ecology of aquatic Diptera - a tribute to Ole A. Scether, pp. 155-164. Caddis Pr., Columbus.

Kornijów, R. and Halkiewicz, A. 2007a. Are the larvae of Propsilocerus lacustris Kieffer 1923 (Diptera: Chironomidae) favoured by nutrientrich lakes? - Aquat. Insects 29: 187-194.

Kosnicki, E. and Sites, R. W. 2007a. Leastdesired index for assessing the effectiveness of grass riparian filter strips in improving water quality in an agricultural region. - Envir. Ent. 36: 713-724.

Kratzer, E. B. and Batzer, D. P. 2007a. Spatial and temporal variation in aquatic macroinvertebrates in the Okefenokee Swamp, Georgia, USA. - Wetlands 27: 127140.

Krno, I., Šporka, F., Pastuchová, Z., Derka, T., Čiamporová-Zat’ovičová, Z., Bulánková, E., Hamerlík, L. and Illéšová, D. 2007a.
Assessment of the ecological status of streams in two Carpathian subregions. - Int. Rev. Hydrobiol. 92: 564-581.

Kumari, M., Kangur, K. and Haldna, M. 2007a. Variation of macrozoobenthos communities in the reed Phragmites australis belt of two large shallow lakes. -Proc. Eston. Acad. Sci. Biol. Ecol. 56: 141-153.

Langton, P. H. and Pinder, L. C. V. 1978a. Keys to the adult male Chironomidae of Britain and Ireland. Vol. 1: Introductory text, keys, references, checklist and index; Vol. 2: Illustrations of the hypopygia (text-figures 114-260), and a supplement identifying sixteen species recently recorded from Britain and Ireland (text-figures 261-276). Freshwat. Biol. Ass., Scient. Publ. 64: $239+$ 168 pp.

Lawson, I. T., Gathorne-Hardy, F. J., Church, M. J., Newton, A. J., Edwards, K. J., Dugmore, A. J. and Einarsson, A. 2007a. Environmental impacts of the Norse settlement: palaeoenvironmental data from Mývatnssveit, northern Iceland. - Boreas 3: 1-19.

Lee, S.-B. and Choi, J. 2007a. Effects of bisphenol A and ethynyl estradiol exposure on enzyme activities, growth and development in the fourth instar larvae of Chironomus riparius (Diptera, Chironomidae). - Ecotoxic. envir. Saf. 68: 84-90.

Leichtfried, M. 2007a. The energy basis of the consumer community in streams yesterday, today and tomorrow - Int. Rev. Hydrobiol. 92: 363-377.

Lencioni, V., Marziali, L. and Rossaro, B. 2007a. The first record of Parochlus kiefferi (Garrett, 1925) (Diptera, Chironomidae, Podonominae) from Italy. - Ent. News 118: 127-133.

Lencioni, V., Rossaro, B. and Maiolini, B. 2007a. Alpine chironomid distribution: a mere question of altitude? - In: Andersen, T. (ed.): Contributions to the systematics and ecology of aquatic Diptera - a tribute to Ole A. Scether, pp. 165-180. Caddis Pr., Columbus.

Lewandowski, J., Laskov, C. and Hupfer, M. 2007a. The relationship between Chironomus plumosus and the spatial distribution of porewater phosphate, and ammonium in lake sediments. - Freshwat. Biol. 52: 331-343.

Liu, X.-Q. and Wang, H.-Z. 2007a. Food composition and dietary overlap of macroinvertebrates in a shallow eutrophic lake in China: spatial and temporal variations. - 
Fundam. appl. Limnol. [= Arch. Hydrobiol.] 168: 71-82.

Londoño, D. K., Siqueira, H. A.A., Wang, H., Sarath, G., Lydy, M. J. and Siegfried, B. D. 2007a. Cloning and expression of an atrazine inducible cytochrome P450, CYP4G33, from Chironomus tentans (Diptera: Chironomidae). - Pesticide Biochem. Physiol. 89: 104-110.

Lumb, C. E., Johnson, T. B., Cook, H. A. and Hoyle, J. A. 2007a. Comparison of lake whitefish (Coregonus clupeaformis) growth, condition, and energy density between Lakes Erie and Ontario. - J. Gt Lakes Res. 33: 314325.

MacCausland, A. and McTammany, M. E. 2007a. The impact of episodic coal mine drainage pollution on benthic macroinvertebrates in streams in the Anthracite region of Pennsylvania. - Envir. Pollut. 149: 216-226.

Makarchenko, E. A. and Makarchenko, M. A. 2007a. A review of Tokunagaia Sæther (Diptera: Chironomidae) from the Russian Far East, with the description of four new species. - In: Andersen, T. (ed.): Contributions to the systematics and ecology of aquatic Diptera - a tribute to Ole A. Scether, pp. 181-192. Caddis Pr., Columbus.

Mancinelli, G., Costantini, M. L. and Rossi, L. 2007a. Top-down control of reed detritus processing in a lake littoral zone: Experimental evidence of a seasonal compensation between fish and invertebrate predation. - Int. Rev. Hydrobiol. 92: 117-134.

Marshall, J. D., Lang, B., Crowley, S. F., Weedon, G. P., van Calsteren, P., Fisher, E. H., Holme, R., Holmes, J. A., Jones, R. T., Bedford, A., Brooks, S. J., Bloemendal, J., Kiriakoulakis, K. and Ball, J. D. 2007a. Terrestrial impact of abrupt changes in the North Atlantic thermohaline circulation: Early Holocene, UK. - Geology 35: 639-642.

Martin, J., Blinov, A., Alieva, K. and Hirabayashi, K. 2007a. A molecular phylogenetic investigation of the genera closely related to Chironomus Meigen (Diptera: Chironomidae). - In: Andersen, T. (ed.): Contributions to the systematics and ecology of aquatic Diptera - a tribute to Ole A. Scether, pp. 193-203. Caddis Pr., Columbus.

Martínez-Guitarte, J. L., Planelló, R. and Morcillo, G. 2007a. Characterization and expression during development and under environmental stress of the genes encoding ribosomal proteins L11 and L13 in Chironomus riparius. - Comp. Biochem. Physiol. Pt B: Biochem. molec. Biol. 147: 590-596.

Massaferro, J. and Vandergoes, M. 2007a. Chironomid records: Postglacial Southern hemisphere. - In: Elias, S. A. (ed.): Encyclopedia of Quaternary sciences 1: 398408. Elsevier, Oxf.

Matsuzaki, S.-i. S., Usio, N., Takamura, N. and Washitani, I. 2007a. Effects of common carp on nutrient dynamics and littoral community composition: roles of excretion and bioturbation. - Fundam. appl. Limnol. [= Arch. Hydrobiol.] 168: 27-38.

Megan, M. H., Nash, M. S., Neale, A. C. and Pitchford, A. M. 2007a. Biological integrity in Mid-Atlantic Coastal Plains headwater streams. - Envir. Monit. Assess. 124: 141-156.

Mokany, A. 2007a. Impact of tadpoles and mosquito larvae on ephemeral pond structure and processes. - Mar. Freshwat. Res. 58: 436444.

Moretti, M. S., Gonçalves Júnior, J. F., Ligeiro, R. and Callisto, M. 2007a. Invertebrates colonization on native tree leaves in a Neotropical stream (Brazil). - Int. Rev. Hydrobiol. 92: 199-210.

Moubayed-Breil, J. 2007a. Polypedilum (Cerobregma) lotensis, new species, and $P$. (C.) saetheri, new species, from lowland streams and rivers in France (Diptera: Chironomidae). - In: Andersen, T. (ed.): Contributions to the systematics and ecology of aquatic Diptera - a tribute to Ole A. Sæether, pp. 205-213. Caddis Pr., Columbus.

Murray, D. A. 2007a. Limnophyes platystylus new species (Diptera: Chironomidae, Orthocladiinae) from Ireland. - In: Andersen, T. (ed.): Contributions to the systematics and ecology of aquatic Diptera - a tribute to Ole A. Scether, pp. 215-218. Caddis Pr., Columbus.

Nalepa, T. F., Fanslow, D. L., Pothoven, S. A., Foley III, A. J. and Lang, G. A. 2007a. Longterm trends in benthic macroinvertebrate populations in Lake Huron over the past four decades. - J. Gt Lakes Res. 33: 421-436.

Nashchekin, D., Masich, S., Soop, T., Kukalev, A., Kovrigina, E., Nashchekina, O. and Daneholt, B. 2007a. Two splicing isoforms of the Y-box protein ctYB-1 appear on the same mRNA molecule. - FEBS J. 274: 202-211. 
Nelson, S. M. and Andersen, D. C. 2007a. Variable role of aquatic macroinvertebrates in initial breakdown of seasonal leaf litter inputs to a cold-desert river. - SWest. Nat. 52: 219228.

Nentwig, G. 2007a. Effects of pharmaceuticals on aquatic invertebrates. Part II: The antidepressant drug fluoxetine. - Archs envir. Contam. Toxic. 52: 163-170.

Nielsen, B. O. and Nielsen, L. B. 2007a. Soil Diptera of a beech stand and an arable field: A comparison of dipteran emergence in neighbouring sites. - Pedobiologia 51: 33-43.

Niitsuma, H. 2007a. Saetheromyia, a new genus of Tanypodinae from Japan (Diptera: Chironomidae). - In: Andersen, T. (ed.): Contributions to the systematics and ecology of aquatic Diptera - a tribute to Ole A. Scether, pp. 219-224. Caddis Pr., Columbus.

Nissling, A., Jacobsson, M. and Hallberg, N. 2007a. Feeding ecology of juvenile turbot Scophthalmus maximus and flounder Pleuronectes flesus at Gotland, Central Baltic Sea. - J. Fish Biol. 70: 1877-1897.

Normant, M., Korthals, J. and Szaniawska, A. 2007a. Epibiota associated with setae on Chinese mitten crab claws Eriocheir sinensis H. Milne-Edwards, 1853: a first record. Oceanologia 49: 137-143.

Nowak, C., Hankeln, T., Schmidt, E. R. and Schwenk, K. 2007a. Development and localization of microsatellite markers for the sibling species Chironomus riparius and Chironomus piger (Diptera: Chironomidae). Molec. Ecol. Notes 6: 915-917.

Nowak, C., Vogt, C., Barateiro Diogo, J. and Schwenk, K. 2007a. Genetic impoverishment in laboratory cultures of the test organism Chironomus riparius. - Envir. Toxic. Chem. 26: 1018-1022.

Nunn, A. D., Harvey, J. P. and Cowx, I. G. 2007a. The food and feeding relationships of larval and $0+$ year juvenile fishes in lowland rivers and connected waterbodies. I. Ontogenetic shifts and interspecific diet similarity. - J. Fish Biol. 70: 726-742.

Ogendi, G. M., Brumbaugh, W., Hannigan, R. E. and Farris, J. L. 2007a. Effects of acid volatile sulfide on black shale sediment-metal bioavailability and toxicity to midge larvae, Chironomus tentans. - Envir. Toxic. Chem. 26: 130-139.
Olomukoro, J .O. 2007a. Salinity and the macrobenthic community structure in Eichhornia crassipes of Warri River, Nigeria. - J. biol. Sci. 7: 309-314.

Olomukoro, J. O. and Moyede, A. O. 2007a. Acute toxic effects of organic effluents on Chironomus travalensis [sic!] Kieffer (Chironomidae: Diptera). - Toxic. envir. Chem. 89: 249-254.

Olsen, D. A., Matthaei, C. D. and Townsend, C. R. 2007a. Patch history, invertebrate patch dynamics and heterogeneous community composition: perspectives from a manipulative stream experiment. - Mar. Freshwat. Res. 58: 307-314.

Omesová, M.and Helešic, J. 2007a. Vertical distribution of invertebrates in bed sediments of a gravel stream in the Czech Republic. Int. Rev. Hydrobiol. 92: 480-490.

Ortiz, J. D. and Puig, M. A. 2007a. Point source effects on density, biomass and diversity of benthic macroinvertebrates in a Mediterranean stream. - River Res. Applics 23: 155-170.

Osman, A. M. and van Noort, P. C. M. 2007a. Comparison of key enzymes in the zebra mussel, Dreissena polymorpha, the earthworm Allolobophora chlorotica and Chironomus riparius larvae. - Ecotoxic. envir. Saf. 67: 212-217.

Oyewo, E. A. and Jacobsen, R. E. 2007a. Polypedilum (Pentapedilum) epleri, a new species from the eastern USA (Diptera: Chironomidae). - In: Andersen, T. (ed.): Contributions to the systematics and ecology of aquatic Diptera - a tribute to Ole A. Scether, pp. 225-234. Caddis Pr., Columbus.

Paasivirta, L. 2007a. Chironomid species in Finnish springs and their surroundings. - In: Andersen, T. (ed.): Contributions to the systematics and ecology of aquatic Diptera - a tribute to Ole A. Scether, pp. 235-246. Caddis Pr., Columbus.

Paggi, A. C. 2007a. A new Neotropical species of the genus Thienemanniella Kieffer, 1911 (Diptera: Chironomidae, Orthocladiinae). - In: Andersen, T. (ed.): Contributions to the systematics and ecology of aquatic Diptera - $a$ tribute to Ole A. Scether, pp. 247-254. Caddis Pr., Columbus.

Panatta, Á., Stenert, C., Martins dos Santos, E. and Maltchik, L. 2007a. Diversity and distribution of chironomid larvae in wetlands 
in southern Brazil. - J. Kans. ent. Soc. 80: 229-242.

Papp, Z., Bortolotti, G. R., Sebastian, M. and Smits, J. E. G. 2007a. PCB congener profiles in nestling tree swallows and their insect prey. - Archs envir. Contam. Toxic. 52: 257-263.

Park, S. Y., Choi, J. 2007a. Cytotoxicity, genotoxicity and ecotoxicity assay using human cell and environmental species for the screening of the risk from pollutant exposure. - Envir. Int. 33: 817-822.

Parr, T. D., Tait, R. D., Maxon, C. L., Newton III, F. C. and Hardin, J. L. 2007a. A descriptive account of benthic macrofauna and sediment from an area of planned petroleum exploration in the southern Caspian Sea. - Estuar. coast. Shelf Sci. 71: 170-180.

Paz, S. and Broza, M. 2007a. Wind direction and its linkage with Vibrio cholerae dissemination. - Envir. Hlth Perspect. 115: 195-200.

Péry, A. R. R., Ducrot, V., Geffard, A. and Garric, J. 2007a. Do differences between metal body residues reflect the differences between effects for Chironomus riparius exposed to different sediments? Chemosphere 66: 397-403.

Pfenninger, M., Nowak, C., Kley, C., Steinke, D. and Streit, B. 2007a. Utility of DNA taxonomy and barcoding for the inference of larval community structure in morphologically cryptic Chironomus (Diptera) species. - Molec. Ecol. 16: 1957-1968.

Ponti, M., Colangelo, M. A. and Ceccherelli, V. U. 2007a. Composition, biomass and secondary production of the macrobenthic invertebrate assemblages in a coastal lagoon exploited for extensive aquaculture: Valle Smarlacca (northern Adriatic Sea). - Estuar. coast. Shelf Sci. 75: 79-89.

Pothoven, S. A., Vanderploeg, H. A., Cavaletto, J. F., Krueger, D. M., Mason, D. M. and Brandt, S. B. 2007a. Alewife planktivory controls the abundance of two invasive predatory cladocerans in Lake Michigan. Freshwat. Biol. 52: 561-573.

Planelló, R., Martínez-Guitarte, J. L. and Morcillo, G. 2007a. Ribosomal genes as early targets of cadmium-induced toxicity in Chironomus riparius larvae. - Sci. tot. Envir. 373: 113-121.

Porinchu, D. F., Potito, A. P., MacDonald, G. M. and Bloom, A. M. 2007a. Subfossil chironomids as indicators of recent climate change in Sierra Nevada, California, lakes. Arct. Antarct. alp. Res. 39: 286-296.

Przhiboro, A. and Sæther, O. A. 2007a. Limnophyes (Diptera: Chironomidae) from northwestern Russia. - Aquat. Insects 29: 4958.

Purcell, L. A. and Giberson, D. J. 2007a. Effects of an azinphos-methyl runoff event on macroinvertebrates in the Wilmot River, Prince Edward Island, Canada. - Can. Ent. 139: 523-533.

Qu, X.-d., Cao, M., Shao, M.-l., Li, D.-f. and Cai, Q.-h. 2007a. Macrobenthos in Jinping reach of Yalongjiang River and its main tributaries. Chin. J. appl. Ecol. 18: 158-162.

Råberg, S. and Kautsky, L. 2007a. A comparative biodiversity study of the associated fauna of perennial fucoids and filamentous algae. Estuar. coast. Shelf Sci. 73: 249-258.

Raats, D. and Halpern, M. 2007a. Oceanobacillus chironomi sp. nov., a halotolerant and facultatively alkaliphilic species isolated from a chironomid egg mass. - Int. J. syst. evolut. Microbiol. 57: 255-259.

Raunio, J., Paavola, R. and Muotka, T. 2007a. Effects of emergence phenology, taxa tolerances and taxonomic resolution on the use of the Chironomid Pupal Exuvial Technique in river biomonitoring. - Freshwat. Biol. 52: 165-176.

Rivers-Moore, N. A., De Moor, F. C., Morris, C. and O'Keeffe; J. 2007a. Effect of flow variability modification and hydraulics on invertebrate communities in the Great Fish River (Eastern Cape Province, South Africa), with particular reference to critical hydraulic thresholds limiting larval densities of Simulium chutteri Lewis (Diptera, Simuliidae). - River Res. Applics 23: 201-222.

Robinson, C. T., Hieber, M., Wenzelides, V. and Lods-Crozet, B. 2007a. Macroinvertebrate assemblages of a high elevation stream/lake network with an emphasis on the Chironomidae. - Fundam. appl. Limnol. (= Arch. Hydrobiol.) 169: 25-36.

Rocha-Ramírez, A., Ramírez-Rojas, A., ChávezLópez, R. and Alcocer, J. 2007a. Invertebrate assemblages associated with root masses of Eichhornia crassipes (Mart.) Solms-Laubach 1883 in the Alvarado lagoonal system, Veracruz, Mexico. - Aquat. Ecol. 41: 319-333. 
Rolland, N. and Larocque, I. 2007a. The efficiency of kerosene flotation for extraction of chironomid head capsules from lake sediments samples. - J. Paleolimnol. 37: 565572.

Roman, Y. E., De Schamphelaere, K. A. C., Nguyen, L. T. H. and Janssen, C. R. 2007a. Chronic toxicity of copper to five benthic invertebrates in laboratory-formulated sediment: Sensitivity comparison and preliminary risk assessment. - Sci. tot. Envir. 387: 128-140.

Roque, F. O. and Trivinho-Strixino, S. 2007a. Spatial distribution of chironomid larvae in low-order streams in southeastern Brazilian Atlantic Forest, a multiple scale approach. In: Andersen, T. (ed.): Contributions to the systematics and ecology of aquatic Diptera - a tribute to Ole A. Scether, pp. 255-264. Caddis Pr., Columbus.

Roque, F. O., Trivinho-Strixino, S., Messias, M. C. and Couceiro, S. R. M. 2007a. Female and immature stages of Oukuriella epleri Messias \& Fittkau, 1997, a freshwater sponge-dwelling Chironomidae. - Aquat. Insects 29: 235-240.

Roque, F. O., Trivinho-Strixino, S., Milan, L. and Leite, J. G. 2007a. Chironomid species richness in low-order streams in the Brazilian Atlantic Forest: a first approximation through a Bayesian approach. - J. N. Am. benthol. Soc 26: 221-231.

Rossaro, B., Marziali, L., Cardoso, A. C., Solimini, A., Free, G and Giacchini, R. 2007a. $\mathrm{A}$ biotic index using benthic macroinvertebrates for Italian lakes. - Ecol. Indicators 7: 412-429.

Rossaro, B., Solimini, A., Lencioni, V., Marziali, L., Giacchini, R. and Parenti, P. 2007a. The relationship between body size, pupal thoracic horn development and dissolved oxygen in Chironomini (Diptera: Chironomidae). Fundam. appl. Limnol. (= Arch. Hydrobiol.) 169: 331-339.

Runck, C. 2007a. Macroinvertebrate production and food web energetics in an industrially contaminated stream. - Ecol. Applics 17: 740753.

Ryner, M., Gasse, F., Rumes, B. and Verschuren, D. 2007a. Climatic and hydrological instability in semi-arid equatorial East Africa during the late Glacial to Holocene transition: A multi-proxy reconstruction of aquatic ecosystem response in northern Tanzania. -
Palaeogeogr. Palaeoclim. Palaeoecol. 248: 440-458.

Sangiorgio, F., Fonnesu, A. and Mancinelli, G. 2007a. Effect of drought frequency and other reach characteristics on invertebrate communities and litter breakdown in the intermittent Mediterranean River Pula (Sardinia, Italy). - Int. Rev. Hydrobiol. 92: 156-172.

Sanseverino, A. M. and Fittkau, E. J. 2007a. Taxonomy of Caladomyia alata (Paggi, 1992) and Caladomyia tuberculata (Reiss, 1972), new combinations (Diptrera: Chironomidae). In: Andersen, T. (ed.): Contributions to the systematics and ecology of aquatic Diptera - a tribute to Ole A. Scther, pp. 265-273. Caddis Pr., Columbus.

Sanz, C., Gorab, E., Ruiz, M. F., Sogo, J. M. and Díez, J. L. 2007a. Chromatin structure of ribosomal genes in Chironomus thummi (Diptera: Chironomidae): tissue specificity and behaviour under drug treatment. Chromosome Res. 15: 429-438.

Scealy, J. A., Mika, S. J.and Boulton, A. J. 2007a. Aquatic macroinvertebrate communities on wood in an Australian lowland river: experimental assessment of the interactions of habitat, substrate complexity and retained organic matter. - Mar. Freshwat. Res. 58: 153165.

Schäfer, R. B., Caquet, T., Siimes, K., Mueller, R., Lagadic, L. and Liess, M. 2007a. Effects of pesticides on community structure and ecosystem functions in agricultural streams of three biogeographical regions in Europe. - Sci. tot. Envir. 382: 272-285.

Schärer, M. T. and Epler, J. H. 2007a. Longerange dispersal possibilities via sea turtle - a case for Clunio and Pontomyia (Diptera: Chironomidae) in Puerto Rico. - Ent. News 118: 273-277.

Scheifhacken, N., Fiek, C. and Rothhaupt, K.-O. 2007a. Complex spatial and temporal patterns of littoral benthic communities interacting with water level fluctuations and wind exposure in the littoral zone of a large lake. Fundam. appl. Limnol. (= Arch. Hydrobiol.) 169: 115-129.

Schenková, J., Jarkovský, J. and Helešic, J. 2007a. Strategies of coexistence of two species: Erpobdella octoculata and E. vilnensis (Hirudinea: Erpobdellidae). - Int. Rev. Hydrobiol. 92: 527-538. 
Schuler, L. J., Landrum, P. F. and Lydy, M. J. 2007a. Response spectrum of pentachlorobenzene and fluoranthene for Chironomus tentans and Hyalella azteca. - Envir. Toxic. Chem. 26: 1248-1257.

Seredszus, F. and Wichard, W. 2007a. Fossil chironomids (Insecta, Diptera) in Baltic amber. - Palaeontographica, Abt. A: Paläozool. Stratigr. 279: 49-91.

Smith, A. J., Bode, R. W. and Kleppel, G. S. 2007a. A nutrient biotic index (NBI) for use with benthic macroinvertebrate communities. - Ecol. Indicators 7: 371-386.

Smith, R. J., Moore, F. R. and May, C. A. 2007a. Stopover habitat along the shoreline of northern Lake Huron, Michigan: emergent aquatic insects as a food resource for spring migrating landbirds. - Auk 124: 107-121.

Soin,T. and Smagghe, G. 2007a. Endocrine disruption in aquatic insects: a review. Ecotoxicology 16: 83-93.

Song, Z. H. 2007a. Effects of pentachlorophenol on Galba pervia , Tubifex sinicus and Chironomus plumousus [sic!] larvae. - Bull. envir. Contam. Toxic. 79: 278-282.

Sotero-Santos, R. B., Rocha, O. and Povinelli, J. 2007a. Toxicity of ferric chloride sludge to aquatic organisms. - Chemosphere 68: 628636.

Souza, M. L., Moulton, T. P., Silveira, R. M. L., Krsulović, F. A. M. and Brito, E. F. 2007a. Responses of Chironomidae (Diptera; Insecta) to the exclusion of shrimps and Ephemeroptera in a coastal forest stream, Rio de Janeiro, Brazil. - Braz. J. Biol. 67: 47-51.

Spänhoff, B., Bischof, R., Böhme, A., Lorenz, S., Neumeister, K., Nöthlich, A. and Küsel, K. 2007a. Assessing the impact of effluents from a modern wastewater treatment plant on breakdown of coarse particulate organic matter and benthic macroinvertebrates in a lowland river. - Wat. Air Soil Pollut. 180: 119129.

Spies, M. 2007a. Case 3355. ORTHOCLADIINAE Kieffer, 1911 and Orthocladius van der Wulp, 1874 (Insecta, Diptera, CHIRONOMIDAE): proposed conservation of subfamilial name and fixation of type species. - Bull. zool. Nomencl. 64: 45-53.

Staiber, W. 2007a. Asymmetric distribution of mitochondria and of spindle microtubules in opposite directions in differential mitosis of germ line cells in Acricotopus. - Cell Tissue Res. 329: 197-203.

Staudacher, K. and Füreder, L. 2007a. Habitat complexity and invertebrates in selected Alpine springs (Schütt, Carinthia, Austria). Int. Rev. Hydrobiol. 92: 465-479.

Stief, P. 2007a. Enhanced exoenzyme activities in sediments in the presence of deposit-feeding Chironomus riparius larvae. - Freshwat. Biol. 52: 1807-1819.

Storey, A. W. and Lynas, J. 2007a. Application of the functional habitat concept to the regulated Lower Ord River, Western Australia, Part I, macroinvertebrate assemblages. Hydrobiologia 592: 499-512.

Strayer, D. L. and Malcom, H. M. 2007a. Submersed vegetation as habitat for invertebrates in the Hudson River estuary. Estuaries Coasts 30: 253-264.

Studinski, J. M. and Grubbs, S. A. 2007a. Environmental factors affecting the distribution of aquatic invertebrates in temporary ponds in Mammoth Cave National Park, Kentucky, USA. - Hydrobiologia 575: 211-220.

Sun, X.-b. and Cui, F.-y. 2007a. (Study of killing and removal on chironomid larvae with oxidants in water treatment system.) - Harbin Gongye Daxue Xuebao (= J. Harbin Inst. Technol.) 39: 242-245.

Sun, X.-B., Cui, F.-Y., Zhang, J.-S., Xu, F. and Liu, L.-J. 2007a. Inactivation of chironomid larvae with chlorine dioxide. - J. hazard. Mater. 142: 348-353.

Sushchik, N. N., Gladyshev, M. I., Kravchuk, E. S., Ivanova, E. A., Ageev, A. V. and Kalachova, G. S. 2007a. Seasonal dynamics of long-chain polyunsaturated fatty acids in littoral benthos in the upper Yenisei river. Aquat. Ecol. 41: 349-365.

Svenning, M.-A., Klemetsen, A. and Olsen, T. 2007a. Habitat and food choice of Arctic charr in Linnévatn on Spitsbergen, Svalbard: the first year-round investigation in a High Arctic lake. - Ecol. Freshwat. Fish 16: 70-77.

Taenzler, V., Bruns, E., Dorgerloh, M., Pfeifle, V. and Weltje, L. 2007a. Chironomids: suitable test organisms for risk assessment investigations on the potential endocrine disrupting properties of pesticides. Ecotoxicology 16: 221-230. 
Takahashi, Y., Houjyo, T., Kohjimoto, T., Takagi, Y., Mori, K., Muraoka, T., Annoh, H., Ogiyama, K., Funaki, Y., Tanaka, K., Wada, Y. and Fujita, T. 2007a. Impact of pretilachlor herbicide and pyridaphenthion insecticide aquatic organisms in model streams. Ecotoxic. envir. Saf. 67: 227-239.

Toro, M., Camacho, A., Rochera, C., Rico, E., Bañón, M., Fernández-Valiente, E., Marco, E., Justel, A., Avendaño, M. C., Ariosa, Y., Vincent, W. F. and Quesada, A. 2007a. Limnological characteristics of the freshwater ecosystems of Byers Peninsula, Livingston Island, in maritime Antarctica. - Polar Biol. 30: 635-649.

Trigal, C, García-Criado, F. and FernándezAláez, C. 2007a. Macroinvertebrate communities of mediterranean ponds (North Iberian Plateau): importance of natural and human-induced variability. - Freshwat. Biol. 52: 2042-2055. [paper gives wrong third author as: Aláez, C.-F.]

Trivinho-Strixino, S. and Siqueira, T. 2007a. New species of Beardius Reiss et Sublette, 1985 (Diptera: Chironomidae) from Southeastern Brazil. - In: Andersen, T. (ed.): Contributions to the systematics and ecology of aquatic Diptera - a tribute to Ole A. Scether, pp. 281286. Caddis Pr., Columbus.

Tronstad, L. M., Tronstad, B. P. and A. C. Benke, A. C. 2007a. Aerial colonization and growth: rapid invertebrate responses to temporary aquatic habitats in a river floodplain. - J. $N$. Am. benthol. Soc. 26: 460-471.

Urrutia, R., Araneda, A., Cruces, F., Torres, L., Chirinos, L., Treutler, H. C., Fagel, N., Bertrand, S., Alvial, I., Barra, R. and Chapron, E. 2007a. Changes in diatom, pollen, and chironomid assemblages in response to a recent volcanic event in Lake Galletué (Chilean Andes). - Limnologica 37: 49-62.

Valdovinos, C., Moya, C., Olmos, V., Parra, O., Karrasch, B. and Buettner, O. 2007a. The importance of water-level fluctuation for the conservation of shallow water benthic macroinvertebrates: an example in the Andean zone of Chile. - Biodivers. Conserv. 16: 30953109.

Vallenduuk, $\mathrm{H}$ and Moller Pillot, H. 2007a. Chironomidae larvae of the Netherlands and adjacent lowlands - General ecology and Tanypodinae. - KNNV Publ., Zeist. 172 pp.

Van Campenhout, K., Bervoets, L., and Blust, R. 2007a. Assimilation efficiencies of $\mathrm{Cd}$ and $\mathrm{Zn}$ in the common carp (Cyprinus carpio): effects of metal concentration, temperature and prey type. - Envir. Pollut. 145: 905-914.

Vandendriessche, S., Messiaen, M., O'Flynn, S., Vincx, M. and Degraer, S. 2007a. Hiding and feeding in floating seaweed: Floating seaweed clumps as possible refuges or feeding grounds for fishes. - Estuar. coast. Shelf Sci. 71: 691703.

Venturino, A., Montagna, C. M. and de D'Angelo, A. M. 2007a. Risk assessment of Magnacide $\mathrm{H}$ herbicide at Rio Colorado irrigation channels (Argentina). Tier 3: studies on native species. - Envir. Toxic. Chem. 26: 177-182.

Verschuren, D. and Eggermont, H. 2007a. Sieve mesh size and quantitative chironomid paleoclimatology. - J. Paleolimnol. 38: 329345.

Vescovi, E., Ravazzi, C., Arpenti, E., Finsinger, W., Pini, R., Valsecchi, V., Wick, L., Ammann, B. and Tinner, W. 2007a. Interactions between climate and vegetation during the Lateglacial period as recorded by lake and mire sediment archives in Northern Italy and Southern Switzerland. - Quatern. Sci. Rev. 26: 1650-1669.

Vogt, C., Belz, D., Galluba, S., Nowak, C., Oetken, M. and Oehlmann, J. 2007a. Effects of cadmium and tributyltin on development and reproduction of the non-biting midge Chironomus riparius (Diptera) - baseline experiments for future multi-generation studies. - J. envir. Sci. Hlth A: Toxic Hazard Subst. envir. Engng 42: 1-9.

Vogt, C., Nowak, C., Barateiro Diogo, J., Oetken, M., Schwenk, K. and Oehlmann, J. 2007a. Multi-generation studies with Chironomus riparius - Effects of low tributyltin concentrations on life history parameters and genetic diversity. - Chemosphere 67: 21922200.

Vogt, C., Pupp, A., Nowak, C., Jagodzinski, L. S., Baumann, J., Jost, D., Oetken, M. and Oehlmann, J. 2007a. Interaction between genetic diversity and temperature stress on life-cycle parameters and genetic variability of Chironomus riparius populations. - Clim. Res. 33: 207-214.

von Fumetti, S., Nagel, P. and Baltes, B. 2007a. Where a springhead becomes a springbrook a regional zonation of springs. - Fundam. appl. Limnol. [= Arch. Hydrobiol.] 169: 3748. 
Walker, I. R. 2007a. Chironomid overview. - In: In: Elias, S. A. (ed.): Encyclopedia of Quaternary sciences 1: 360-366. Elsevier, Oxf.

Walters, D. M., Fritz, K. M. and Philipps, D. L. 2007a. Reach-scale geomorphology affects organic matter and consumer $\delta^{13} \mathrm{C}$ in a forested Piedmont stream. - Freshwat. Biol. 52: 1105-1119.

Wang, L., Robertson, D. M. and Garrison, P. J. 2007a. Linkages between nutrients and assemblages of macroinvertebrates and fish in wadeable streams: implication to nutrient criteria development. - Envir. Mgmt 39: 194212.

Wang, X., Liu, Y. and Paasivirta, L. 2007a. A new species of Propsilocerus Kieffer from Finland (Diptera: Chironomidae, Orthocladiinae). - In: Andersen, T. (ed.): Contributions to the systematics and ecology of aquatic Diptera - a tribute to Ole A. Scether, pp. 309-313. Caddis Pr., Columbus.

Wanner, G. A., Shuman, D. A., and Willis, D. 2007a. Food habits of juvenile pallid sturgeon and adult shovelnose sturgeon in the Missouri River downstream of Fort Randall Dam, South Dakota. - J. Freshwat. Ecol. 22: 81-92.

Watanabe, M., Nakahara, Y., Sakashita, T., Kikawada, T., Fujita, A., Hamada, N., Horikawa, D. D., Wada, S., Kobayashi, Y., and Okuda, T. 2007a. Physiological changes leading to anhydrobiosis improve radiation tolerance in Polypedilum vanderplanki larvae. - J. Insect Physiol. 53: 573-579.

Wikström, S. A. and Kautsky, L. 2007a. Structure and diversity of invertebrate communities in the presence and absence of canopy-forming Fucus vesiculosus in the Baltic Sea. - Estuar. coast. Shelf Sci. 72: 168-176.

Willassen, E. 2007a. Sasayusurika aenigmata Makarchenko (Diptera: Chironomidae, Diamesinae) - a Japanese endemic discovered in the Indian Himalaya. - In: Andersen, T. (ed.): Contributions to the systematics and ecology of aquatic Diptera - a tribute to Ole A. Scether, pp. 3155-320. Caddis Pr., Columbus.

Williams, D. D., Heeg, N. and Magnusson, A. K. 2007a. Habitat background selection by colonizing intermittent pond invertebrates. Hydrobiologia 592: 487-498.
Woodward, C. A and Shulmeister, J. 2007a. Chironomid-based reconstructions of summer air temperature from lake deposits in Lyndon Stream, New Zealand spanning the MIS 3/2 transition. - Quatern. Sci. Rev. 26: 142-154.

Wülker, W. F. 2007a. Two new Chironomus species with fluviatilis-type larvae from the near-shore sandy sediments of Lake Michigan (Diptera: Chironomidae).- In: Andersen, T. (ed.): Contributions to the systematics and ecology of aquatic Diptera - a tribute to Ole A. Scether, pp. 321-333. Caddis Pr., Columbus.

Yamamoto, M., Hirabayashi, K. and Matsuzawa, M. 2007a. The Korean species Hanochironomus tumerestylus Ree, 1992, taken on Ishigaki Island, Japan (Diptera: Chironomidae). - In: Andersen, T. (ed.): Contributions to the systematics and ecology of aquatic Diptera - a tribute to Ole A. Scether, pp. 335-346. Caddis Pr., Columbus.

Yamamuro, A. M. and Lamberti, G. A. 2007a. Influence of organic matter on invertebrate colonization of sand substrata in a northern Michigan stream. - J. N. Am. benthol. Soc. 26: 244-252.

Yoshimura, M. 2007a. Comparison of stream benthic invertebrate assemblages among forest types in the temperate region of Japan. Biodivers. Conserv. 16: 2137-2148.

Xiong, F., Li, W.-C. and Pan, J.-Z. 2007a. Spatial distribution and its environmental analysis of chironomid larvae in Fuxian Lake of Yunnan Province. - Chin. J. appl. Ecol. 18: 179-184.

Żbikowski, J. and Kobak, J. 2007a. Factors influencing taxonomic composition and abundance of macrozoobenthos in extralittoral zone of shallow eutrophic lakes. Hydrobiologia 584: 145-155.

Zettler, M. L. and Daunys, D. 2007a. Long-term macrozoobenthos changes in a shallow boreal lagoon: Comparison of a recent biodiversity inventory with historical data. - Limnologica 37: 170-185.

Zorina, O. V. 2007a. Olecryptotendipes, a new genus in the Harnischia complex (Diptera: Chironomidae) from the Russian Far East. In: Andersen, T. (ed.): Contributions to the systematics and ecology of aquatic Diptera - a tribute to Ole A. Scether, pp. 347-351. Caddis Pr., Columbus. 